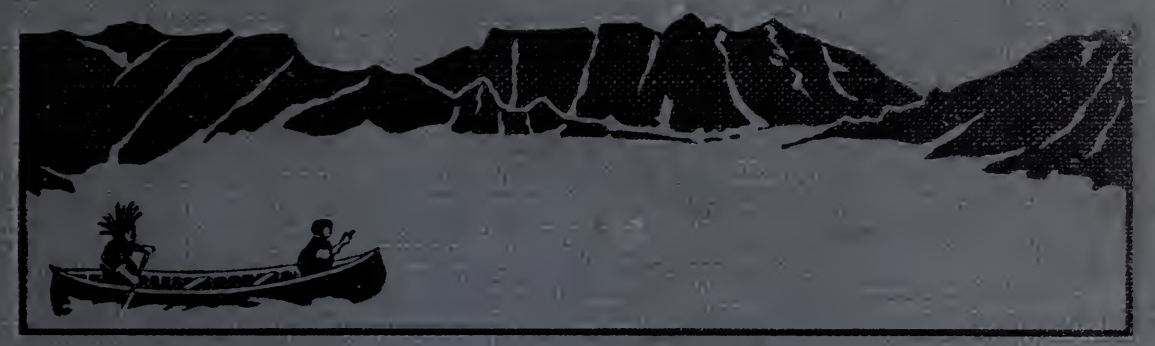

\title{
W][JID U[T]
}

\section{I[N C] ]}

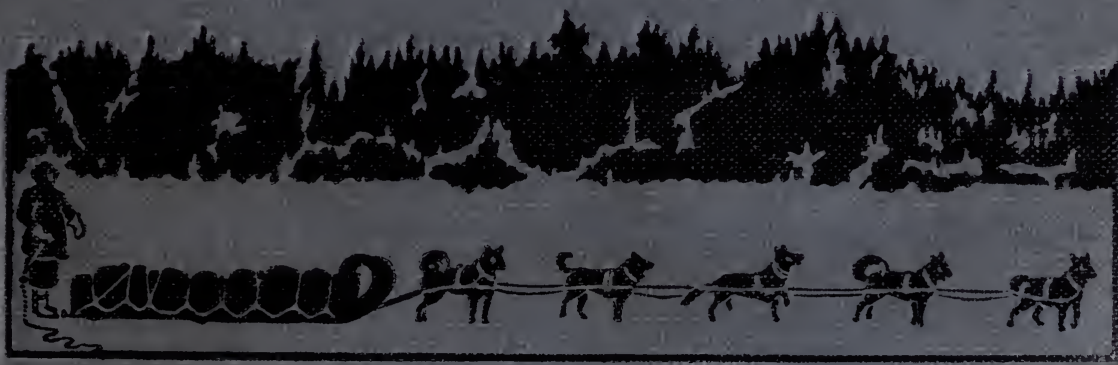




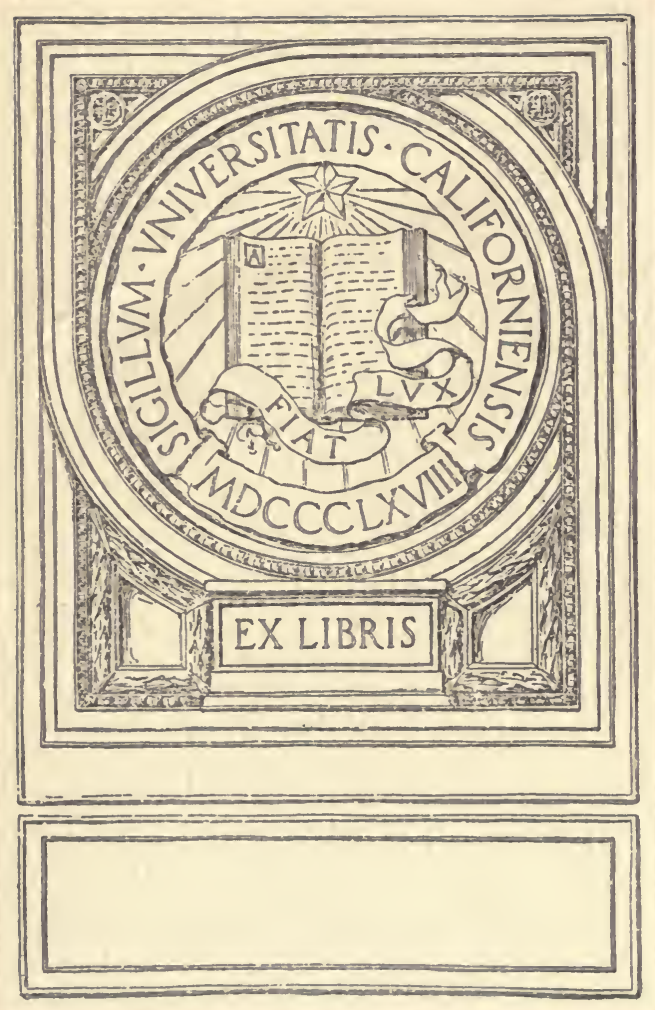








\section{WILD LIFE IN CANADA}


Digitized by the Internet Archive in 2008 with funding from Microsoft Corporation 



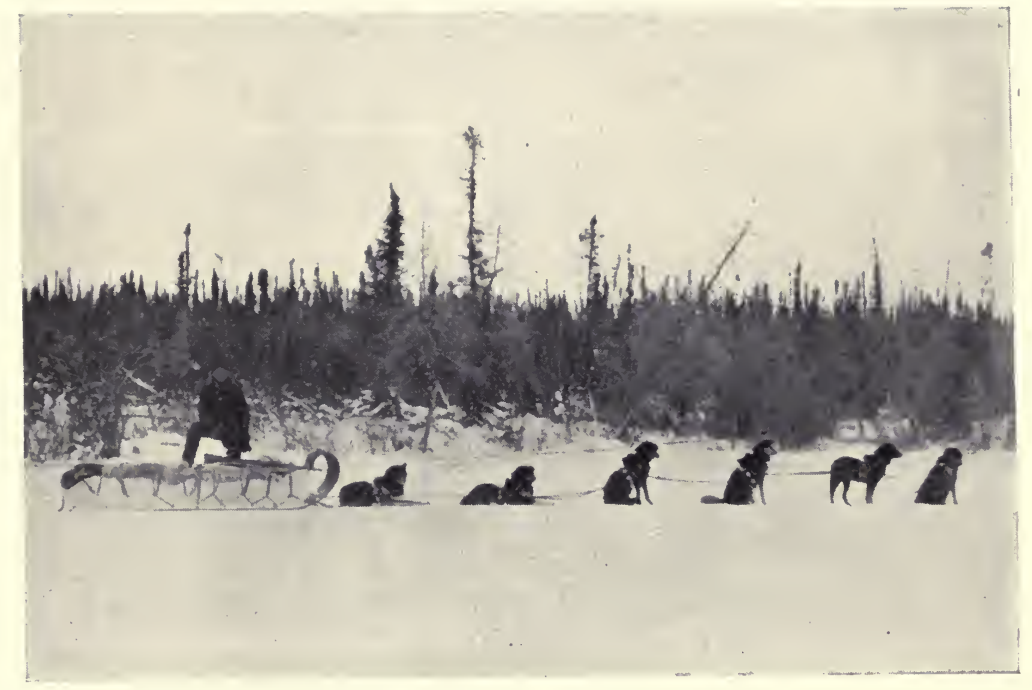

WINTER ON THE TRAIL.

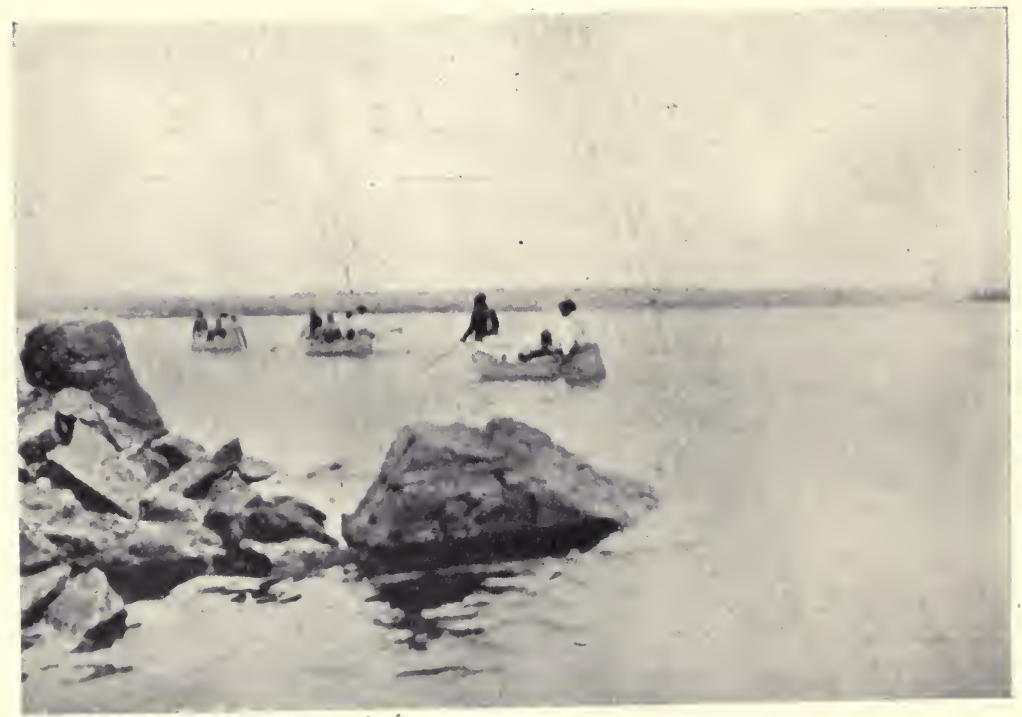

‥ $\because \vdots \vdots \because$ sufimer oN THE TRAIL.

$\therefore \therefore \quad \because \vdots \because \varepsilon ;$

- $\because \because \because \vdots \quad \vdots \therefore \cdots$

- 


\section{WILD LIFE IN CANADA}

BY CAPTAIN ANGUS BUGHANAN, M.C. AUTHOR OF "THREE YEARS OF WAR IN EAST AFRICA"

WITH NUMEROUS PHOTOGRAPHS BY THE AUTHOR

McGLELLAND, GOODGHILD AND STEWART, LIMITED TORONTO

1920 


$$
\begin{aligned}
& F 10^{15} \\
& B 85
\end{aligned}
$$


TO

D. F. B.

A GREAT LOVER OF NATURE AND EVERY ASPECT OF THE ÇLEAN BROAD OUTDOOR WORLD IN FAIR WEATHER OR FOUL, AND WHO KEPT FRESH IN ME EVEN UNTO MANHOOD THE EVER-EAGER DELIGHTS OF BOYHOOD IN ALL LIVING WILD THINGS 



\section{PREFACE}

Canada, in a great belt that runs from sea to sea, across the southern territory of her dominion, is the civilised, rapidly growing country which we all know to-day. Therein, in out-of-the-way places where mankind pass not too often, there are still quantities of big game and fur-bearing animals and wild-fowl to delight the lover of nature and solitude. But it is not of such places that I write in this narrative - not of the outdoor places that are within reach of those who inhabit the populated south country of Canada; for the wanderings which it has been my good fortune to experience, and which henceforth I will endeavour to describe, were through a part of the great unpeopled North, which even to-day comprises more than half of the large Dominion of Canada. So great is the far north territory that there is many a hundred miles on which no white man has yet set foot, and even where the white man has been, in the distant interior near to the Barren Lands, in many cases the footprints have been so few that an old Indian inhabitant of a district could easily count those who had passed in a lifetime on his ten fingers. Though I travelled 785 miles over ice and snow by dog-sled, and 1,044 miles over water in a single canoe, I lay no claim to having done a xi 
great thing, for in face of the rigorous, boundless North a single man's effort must ever seem small.

Again and again I might go back to the solitude of the Great North-and perhaps I will-but I know full well I will always deem the hours of a lifetime all too short to accomplish half that I would wish in that overwhelming vastness that reminds me, with a sternly intimidating dominance, that I am but a tiny, passing atom, active for the moment, but woefully impotent before the timeless reign of the brooding wilderness.

Yet, piece by piece, the character of a new land is revealed, not by the endeavour of one man or one generation, but at the instance of many, and so if the long trails I have made seem little in proportion to the limitless extent that lay before me, I still trust that my investigation of a country lying between the Saskatchewan River and the Arctic Barren Grounds, and between longitudes $101^{\circ}$ and $108^{\circ}$, may add in some measure to man's knowledge of that territory, whether the reader of this narrative be layman with a love of nature, or naturalist who finds delight in following the endeavours of an associate.

In a scientific article recently prepared for publication by J. H. Fleming, C.M.Z.S., C.M.B.O.U., a notable Canadian ornithologist, dealing with the bird life which I collected on this expedition, the writer says :

"Almost the first knowledge we have of the ornithology of the Saskatchewan region is con- 
tained in a series of papers published in the Ibis of 1861-62-63, by Capt. Blakiston, who spent the winter of $1857-58$ at Fort Carlton on the Saskatchewan River, and in 1858 collected at various points in what is now the Province of Saskatchewan. In these papers Capt. Blakiston incorporated much information from Vol. II of the Fauna Boreali-Americana of Richardson and Swainson, and other published sources of information. Since then our knowledge of the birds of Southern Saskatchewan has been considerably enlarged, but strangely enough the ornithology of the great region drained by the Churchill River, and lying to the north of what was, till 1912, the northern boundary of the province, has had little or no attention paid to it. Notes on the birds were made by James M. Macoun, who in 1888 travelled from Lesser Slave Lake east by way of the Athabasca and Churchill Rivers to Lake 'Winnipeg; these notes were eventually published by John Macoun in his Catalogue of Canadian Birds. Less than a dozen birds are in the United States National Museum, collected at $\mathrm{Du}$ Brochet Lake in 1890 and Pelican Narrows on the Churchill River in 1891 ; probably collected by Henry MacKay and Joseph Hourston, for Roderick MacFarlane. These are the only skins I have seen from the region taken previous to 1914. During the years 1892-93-94, J. Burr Tyrrell, in the course of his explorations of the Barren Grounds, more than once traversed the Churchill River and his official reports ${ }^{1}$ con-

1 Annual Report Geological Survey of Canada, viii. (new series), Part D, pp. 5D to 120D, Ottawa, 1896; ibid. ix. 1896, Part F (1897). 
tain the best description we have of this region; in these reports there are short references to birds. When Edward A. Preble wrote his great report on the natural history of the AthabascaMackenzie Region ${ }^{1}$ he included all that was known of the birds of the Churchill River up to 1908.

"When the boundaries of Saskatchewan were in 1912 extended north to include a part of the old North-West Territory, so little was known by the Provincial Government of the natural history of the northern part of the country that Angus Buchanan determined to investigate the country lying between the Saskatchewan River and the Barren Grounds. He left Prince Albert on May 6, 1914, and descended the Beaver River to Lake Île à la Crosse, and the Churchill River, thence continuing upstream on Reindeer River and Reindeer Lake, entering the Cochrane River on July 18, and Lake Du Brochet on August 1. His base camp was made north of this lake, and here he proposed to winter, but hearing of the outbreak of the war in late October he decided to return to the South, and reached Regina on January 15, 1915, after an absence of eight and a half months, during which he travelled nearly two thousand miles by canoe and dogsleigh. The birds collected during this expedition were divided; part were deposited in the Provincial Museum at Regina, and the rest were handed over to me ; they form a very important

1 A Biological Investigation of the Athabasca-Mackenzie Region. North American Fauna, No. 27. Bureau of Biological Survey, Washington, 1908. 
addition to our knowledge of the birds of the region drained by the Churchill River, and are in fact the first collection made in far Northern Saskatcherwan."

It may seem odd to the reader that I make record at this date of an expedition undertaken in the year 1914, yet this may be easily explained, and, I hope, the delay forgiven, as such a circumstance is entirely due to the exigencies of the Great War, during which it was every. able man's duty to abandon civil occupation and take up arms in defence of home and country, even though such action would rudely shake, and perhaps break, the foundation of almost any career. On receiving my release from the Army I have made haste to return to the full pages of my diary of 1914 and to labour to record my experiences of that time in the hope that they might be in some measure instructive to those setting forth on like adventure, and to those who take an interest in wild life of any kind. Moreover, whatever I experienced in 1914 of the country I then travelled through still retains the native novelty, for had other footsteps followed mine I would have been told so by the Government authorities with whom I remain in correspondence. So, through the years of war that have passed, the North remains the silent, unbounded solitude that my canoe and dogsled intruded on for a brief space; since then no like expedition has passed along that pathless route.

Every traveller appreciates or depreciates his reception by the inhabitants of the country he 
travels through, and, in this instance I owed much to the good services of the Saskatchewan Provincial Government, who loyally supported the expedition at the start; to the Hudson Bay Company, whose factors were ever ready to assist and advise me in every way they could; and lastly, though I say it of people who cannot read and know my appreciation, to the Cree and Chipewyan Indians, who proved quaintly friendly and unselfish in their hospitality, and resourceful, magnificent fellow-travellers on the trail on the few occasions that I came among them, and when one or more aided me when trailing by dog-train over ice and snow. To all I owe the thanks and gratitude of a traveller safely returned from a hazardous quest who enjoys pleasant reminiscences of the weather-beaten, kindly faces of worthy outdoor people, and still recalls their strong handshake of genuine comradeship that on many a hard trail welcomed me in, or pointed the way forth with well-wishing. 


\title{
C O N T E N T S
}

\section{CHAPTER I}

IN A FRONTIER SETTLEMENT

The poor rich-The new-comer-The police-Joe Ryan . pp. 1-10

\section{CHAPTER II}

\author{
OUT TO LAKE ÎLE À LA CROSSE
}

Outfit-How to pack-Launching canoe-Forcing way through iceEntering Beaver River-Early nesting birds-Meeting with Red-skins -Photographing nests-On Beaver River-Trapping mammals

pp. 11-32

\section{CHAPTER III}

\section{SEEKING THE SANDHILL CRANE}

Groping in the forest-Discovering sandhill eranes-South-west gale bursts-Sandhill crane's nest found-Our culminating disappointment 


\section{CHAPTER IV}

\section{ON THE GREAT CHURCHUL RIVER}

Length of Churchill River-Shagwenaw Lake-Pelican RapidsPelican Lake-Bald eagle's nest-Mosquito pests-Many birds observed -An Indian settlement-Snake Lake-Sandfly Lake-Scouting alone: Indians' appreciation-Black Bear Island Lako-A stiff storm-Great Devil Rapids-Pike stolen by bear-From Rock Lake to StanleyA surprise welcome-Stanley Mission Post-Description of churchRapid River Lake-Possibilities of country-Mink captures large eelRapids on River. pp. 44-91

\section{CHAPTER V}

\section{REINDEER LAKE AND FORT DÚ BROCHET}

Beauty of Reindeer Lake-Fort du Brochet-Lake teems with fishThe Lake Trout-Fish in Reindeer Lake-The Indians' deep-shadowed land

\section{CHAPTER VI}

\section{THE BARREN-GROUND CARIBOU}

Winter haunt of caribou-The last of the roving big game-Search for caribou fails-Building log cabin-The freeze-up-With Indian hunting party-Crossing open water-Hunting alono-Wading through ice-water-Attack by wounded caribou-Carrying pack-load-The soundless land-Caribou in migration-The Chipewyan decreasingShooting caribou-Snaring caribou-Meat needed for men and dogsCaribou hides and their use-Start for caribou ground-Decoying caribou-Photographing caribou-Camera fails to work-A strange dream -Cold spoils camera work . . . . . . . pp. 104-151

\section{CHAPTER VII}

\section{SLED-DOGS OF THE NORTH TRAILS}

Sled-dog population-Cunning of sled-dogs-Dogs of Fort du Brochet-Dogs watch canoes return-Broaking in sled-dogs-Netting winter's fish supply-Trailing over ice and snow-The power of the North-Halting between camps-Making night camp . pp. 152-172 


\section{CHAPTER VIII}

\section{THE TRAPPER}

An Indian cabin-The dead of winter-Gullfoot's dog-teamDigging out young foxes-Fox pelts and their value-Variety of colour in foxes-Area of trap setting-How traps are set-Return to Indian cabin

\section{CHAPTER IX}

\section{LEAVING THE LONE LAND}

Dogs give out-Start on return journey-Friendship of nativesCreatures of the wild-Finger frost bitten-Entertained by Cree Indians-Nearing Pelican Narrows-Indian"guides go home-Approaching civiliation-Amusing incidents-End of the long trail pp. 192-213

\section{CHAPTER $\mathrm{X}$}

\section{ANIMALS AND BIRDS COLLECTED AND OBSERVED}




\section{LIST OF ILLUSTRATIONS}

Winter on the Trail . Frontispiece

Summer on the Trail .

The World of the North . . . . . 4

TyPical Sled-dogs $\quad$.

Nestuing Great Horned Owl • . . $\quad$. 26

Lesser Yellow-legs • • • • • 26

The Sandhill Crane . $\quad . \quad$. $\quad . \quad$. 34

Nest and-Eggs of Black Tern . . . . 36

Nest and Eggs of Common Tern . $\quad$. $\quad 36$

Gateways of Magnificent River Between the

LAKE Expansions .

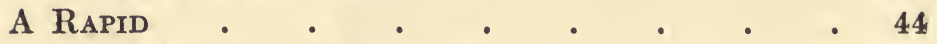

A Bald Eagle's Eyrie $\quad$. $\quad$. $\quad . \quad$. 56

Butterfles on Moist Shore Sand of Reindeer

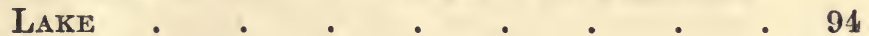

The Landing at Fort du Brochet • • . 94

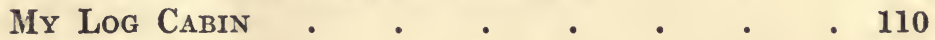

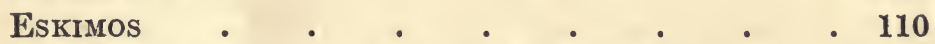

A Male Caribou in Captivity in London . 118

Caribou Resting on a Frozen lake • • . 132

Caribou Traveling in Typical Indian File • 132

Husky Dog . . . . . . . . 156

Pure Husky Female . $\quad$. $\quad$. $\quad$. 156

Expectant, Ever-hungry Dogs • • • 158

Dogs Interested in the Morning Catch of Fish . 158

Timber Stage on which is Hung tire autumn Catch

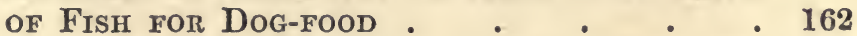

Pure Timber Wolf Female: in captivity, to

Improve BreEd of Sled-dogs . • • • • 162

Listening Attitudes • • • . • 182

Is all Clear? $\quad$ • $\quad$ • $\quad$ • $\quad$ • $\quad$. 182

Dogs Resting South of Theitaga Lake: Trailing

From the BARREN GRounds . . . . 192 



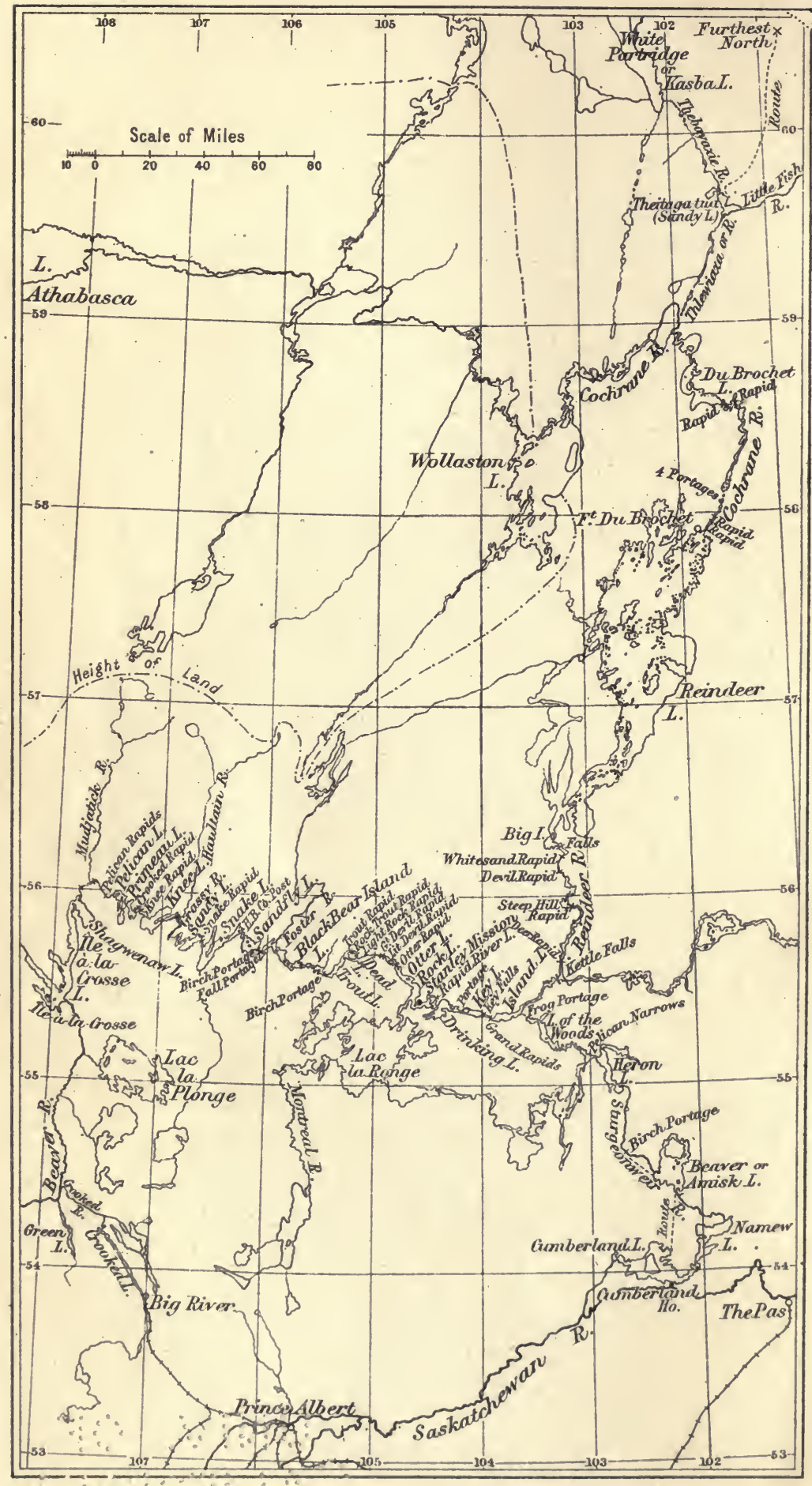




\section{WILD LIFE IN CANADA}

\section{CHAPTER I}

\section{IN A FRONTIER SETTLEMENT}

THE railroad terminates at the crest of a stiff incline a mile short of the head-waters of Crooked Lake. The rural train, which travels the roughlylaid single line on alternate days, completes the monotonous, uneven journey with a final struggle up-grade, between lines of coniferous forest, and comes to a cautious standstill, emitting deepthroated blasts of rebellious protest, in a narrow clearing at the lower edge of the small frontier town of Big River.

Straggling, train-tired passengers are told gruffly that this is the End of the Line.

One enters the settlement-that is, one descends from the train and traverses the total two hundred yards of main thoroughfare-and at once, and thereafter is struck by the conflicting types of men and habitations.

Here civilisation ends and the wilds begin. So far has engineering and enterprise progressed; thenceforward lie the untouched lands of the limitless North. Here commingle the old spirit of the untamed wild and the new spirit of civilisation. There are grim men from the woods 
and the trail, English-speaking, French, Galicians, Halfbreeds, Indians, rough-clad, stalwart, untrammelled, who talk in slow-spoken speech with fearless bearing, while about their feet move their company of dogs-restless, prowling, hungry brutes; neglected summer pensioners, but, in winter, the pride of their masters-the indomitable sled-dog. They are men and beast of their surroundings; hard-fighters who wrest a stern living from virgin forest and stream, and who ask no greater reward than to retain their boundless freedom.

To the men their freedom is their all. They cannot tell you why, again and again they seek the North; yet they cannot leave it. A mood of discontent, or a vivid picture of everlasting pleasure which they paint in imagination, sends most of them, at some time or other, to seek "civilisation," saying, "I will live as other people do." But they seldom, if ever, keep their resolve. They are out on the North trail just as soon as the primitive wildness, which is in them as it is in wild animals, awakes anew and bids them seek again the quiet places. Such men are the vanguard-the unstarred leaders of advancing immigration that, as the rising tide on the seashore, ever overlaps the old mark, and escapes onward, ever onward, to populate the surface of a vast new country.

Less prominent, far less striking, in this village of the parting of the ways, are the people of the New World-mill clerks, and trading storekeepers, and their assistants; and their twoscore wives and daughters. All somewhat dim- 
inutive against the strong contrast of frontier manhood; somewhat unworthy-even trivial. Each holding dearly to business, to the guiling dress of the shop counter, and the much frayed ribbons of a gaudy, doubtful society.

These are the interlopers, the people from the South ; the harbingers of civilisation, who have come, with their dollars and their trash, to disturb the beauty and peace of virgin nature. And those are the people who speak, with pride, of the Town-site; who proclaim the magnificence of a meagre street or two, of meretricious framebuilt houses in narrow land plots; and who point to the importance of a lumber mill and a gaunt, top-heavy Boarding House as if, on that guarantee, the future of Big River were assured, and their fortunes.

They forget too easily, in their vanity, that it is not to those things that they owe their prosperity, but to the wonderful richness of the nature around them. And theirs is a circumstance that always fills me with a certain amount of sadness. They may be rich in a worldly way, but how poor they are of intellectual enthusiasm-at their feet lies the broad, beautiful world, yet must they trample it under with eyes only for the god of Gold, and Power, and Pleasure. ... Ah! wellit is their life; small perhaps, perhaps somewhat narrow, but they know no other. They are part of the great scheme of things ; impelled by heritage and circumstance to follow a welltrodden channel, and counselled by a strong commercial instinct to launch out into activity and endeavour, though, in life's short pilgrimage, 
they may destroy the rich growth of centuries in building up the ardent ambitions of the hour.

But the greater things, the things which are neither little nor personal to any man, the phantom forces which are behind the Universethe forces which ordain mankind to life, to an existence, and to death-as fish, or fowl, or fly, is ordered-those are the forces which are the soul of the North. And it is a soul which whispers that the land and water and sky of nature's universe will grow and nourish and still be beautiful while race after race of mankind rise up, halt a little, and pass away.

To anyone who valued, with the fresh outlook of a stranger, the intensity of first impressions, the world of the North showed calm and of fathomless beauty and mystery, and dominated all; yea, even the foreground of humanity. It was all-powerful, this vastness of eternity, yet all forgiving; and one was constrained to murmur :

So great this beautiful earth,

So little our earthly being,

So let us pass ; each in our own way.

It was in this vein, then, that I mused of the Frontier, and Beyond, on early acquaintance.

Time had passed since the evening of my arrival. I had been two days in Big River-two long days of delightful, ruminating freedom amongst the older bushmen of the place. And now it was the evening of the second day.

I sat at the only table occupied in the great, bare, paintless, featureless, interior of the barn- 


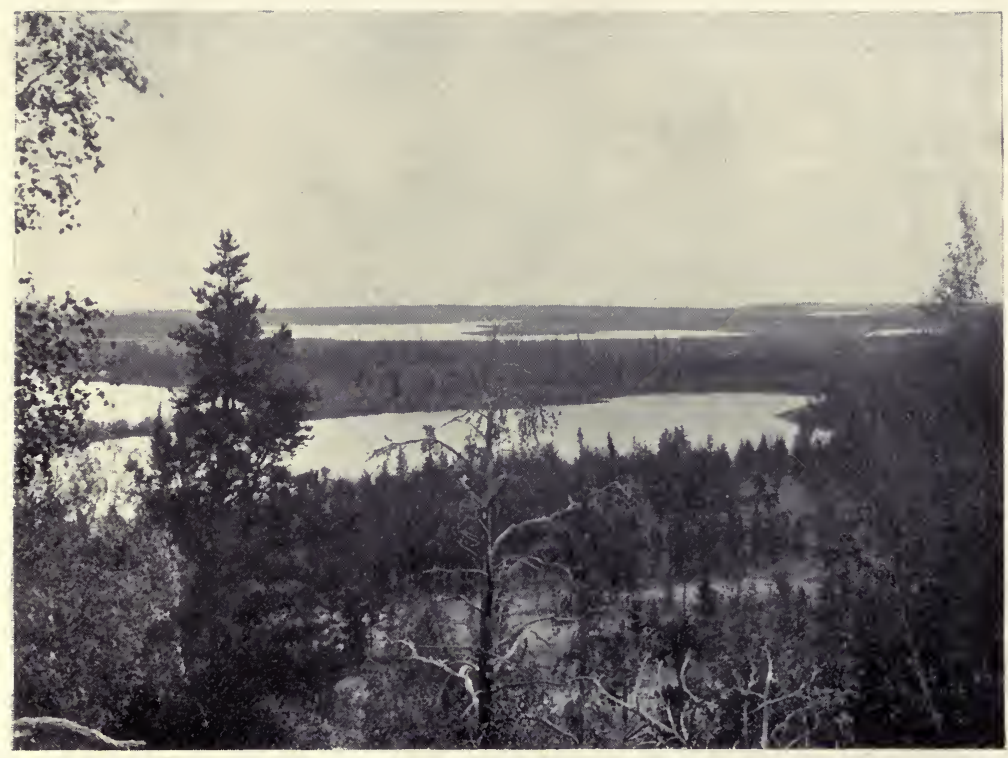

THE WORLD OF THE NORTH.

Limitless uninhabited expanse of land, lake, and river.

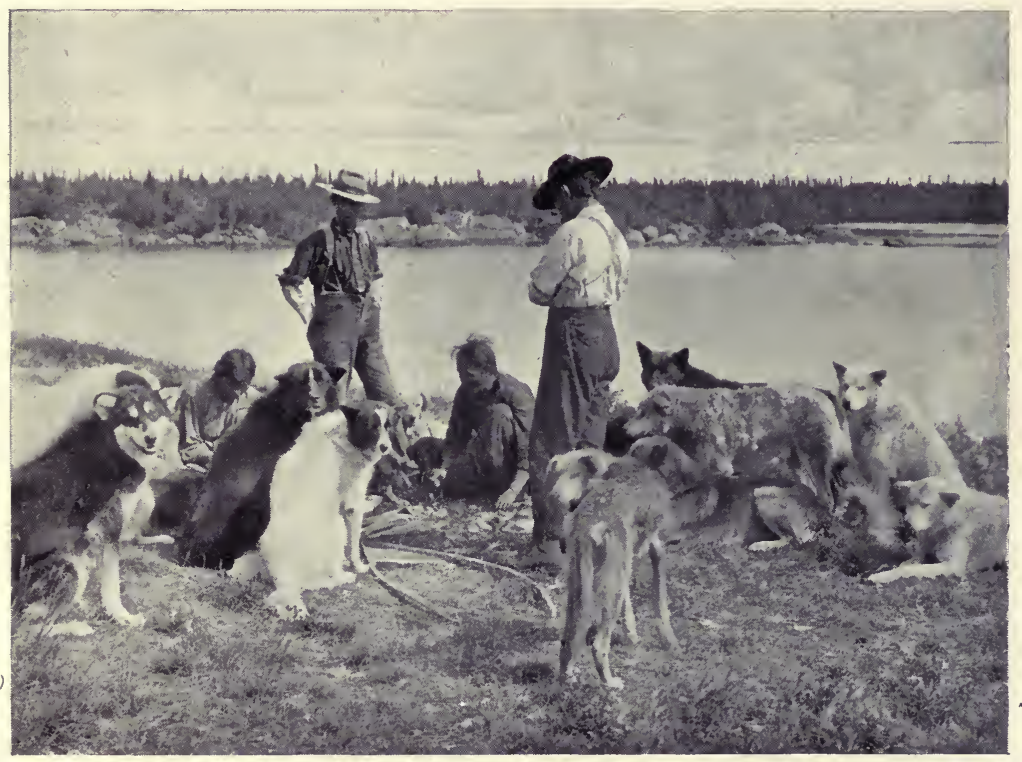

TYPICAL SLED-DOGS.

Idle summer pensioners; the pride of their masters in winter. 

like Boarding House of Big River. I had finished the evening meal-a hungry man's full fare of pork and beans and potatoes, accompanied by the inevitable thick-rimmed mug of hot tea-and looked round me with the air of one who is satisfied and who has accomplished the final task of a long, pleasurable day. I knew, in hail-fellow-well-met fashion, all but one of the half-dozen others at the table. There were the Engineer and the Conductor, who had come in, an hour ago, on the evening trainMinnesota Joe, a self-famed, talkative trapper from the States-and Pete Deschambault and Louis Breau, two French-Canadian lumber-jacks.

But who was the new-comer? That was what I pondered with a half-hope that he might be an experienced canoe-man such as I wanted to hire for a long journey. He was of middle age and uncommunicative, this stranger who sat among them; he ate his evening meal preoccupied, and silently. Undoubtedly he came from the quiet places and from the hard trail. Was not his face furrowed and worn with exposure, was not his hair rough and untended-and ate he not wolfishly, as a man who always knows great hunger?

When the new-comer and the two lumber-jacks had risen from their meal and left the Boarding House, I addressed the Train-Conductor.

"Seen new-comer before, Neal ?"

"Ya, stranger. Name, Joe Ryan. He's just in. Been trapping or lumbering all winter."

"He's a talkative cuss, Neal; meditates as if he were planning next winter's trap line." 
"Ya, stranger, it's the bushman's way. They live not by what they say, but by what they do. Words ain't much use to them; my trade's different."

"Yes, Neal, you've a persuasive tongue, and you make by it. But is there any chance of this new-comer accepting hire for a summer on the canoe trail ?"

"I don't know. It's hard to hire those men for love or money if the work 'don't' appeal to them. Going far, Stranger ?"

"Yes. I leave on the long trail north to Brochet $^{1}$ as soon as ice moves in Crooked Lake. Stiff going, they tell me; few in those parts have been right through. Bad rapids on the Churchill ; blind "takes' 2 on all the lakes."

"Aye, I've heard tell o' it, Stranger, dreary tales too. But Joe's your man, if he will go. He's reckoned a good hand here."

'We parted then-each to bunk for the night.

Next morning, I entered into conversation with Joe Ryan as we were standing together at the entrance to the Boarding House idly enjoying the glorious fresh spring air.

"Do you feel it, man?" I exclaimed, turning to the new-comer with enthusiasm. "This Earth's awakening! this full, rich flood, which, at the bidding of the mellow wind, trembles in every timbre of the forest. The sleep of the snows is over. Is it not so ?"

1 Far North Hudson Bay Fort on north end of Reindeer Lake.

2 Blind "takes" - the heads of rivers where the lake waters find outlet, often concealed behind forested points, or somewhere in a score or two of bays. 
"Ya, Stranger," he answered. "The iron hand is raised, our stripping of the forest is done, the river and the mill can do the rest."

"Ah! Been in the woods, Ryan?"

"Ya."

"Quit now?"

"Ya."

"Know something about canoe and river work?"

"Well-I guess so, Stranger, been riverman and lumber-jack, off and on, ever since I was big enough to work."

"Know the north trail hereabouts?"

"No! Have not been long west. Come from the Ottawa" (River).

"Well, look here, Ryan, the police canoe" is in from Green Lake-just arrived-I've seen Bob Handcock, the police sergeant. Ice is rotten on Crooked Lake, and moving, and passage out is possible inshore for light canoe. Hudson Bay Co. have failed to send me up promised 'breed' who knew the trail, and I'm going to move out now as soon as I've a partner in the canoe. What do you say to tackling the job ? You can go back from Lake lle à la Crosse, if you don't want to carry on after two weeks' trial of it."

"Wall, Stranger, it might be done. I don't know you, you don't know me-that's a great risk on undertakings of this kind, but perhaps

1 North-West Mounted Police. Splendid men, those single representatives of justice who command that law and order be recognised even in distantly remote corners where there is no law except that which their strength of character imposes on lawless men. 
we'll hit it off. You're not Government? No party, no big stores, no following of camp cooks and freighters. What are you out for? Fur, foxes, or prospecting ?"

"No, Ryan, I'm going for none of those things. When you've come off the Drive, when you've had your glorious 'flare up' in the city, and your body and mind are sick and sore with months of summer idleness, what do you long for? Do you not crave again for the freedom of the backwoods; for the great silence; for the peace of the camp fire?"

"Aye, aye, Mate."

"Well, so am I here. There's no rest in the cities. I go to study the birds and animals, and all of nature's things-and to bring, for the Government, specimens for their museum.

"I travel, as you would travel-alone, caring not for the ease and noise of retinue in surroundings which are Ino part of such things. From maps I know something of the main lakes and rivers, and leave the rest to bush-craft.

"What do you say, Ryan, will you come?"

"H'm!-Ya, I guess so, Stranger-never had a chance before to see that darned North Country."

"Right, Joe! Shake! Get what you want in the store, on my account-six months' tobacco, mind-and be around ready to pull out first thing in the morning."

\section{Joe Ryan, Riverman and Lumber-Jack}

Joe Ryan was a hard man. Hard, by nature of his calling; hard, at the bidding of his mind. He has an unforgiving countenance, deep-seared 
and weather-beaten, with no expression that could be defined. Indeed, his face was an uncommitting mask hiding the shrewd brain which had fought with a full measure of the hardships of a bushman's life in the early days of the lumber trade; and which had suffered in the seeking of recompense and pleasure. His was a life, in its naked ruggedness, which hardly constitutes a school for saints. Ryan had gone through the bitter mill of experience, and he knew the full joy, and the full sorrow, of weeks of debauch and devilry when off the Drive.

But, now, at the age of forty-five-which is beyond the prime of a lumber-jack's life-he had learned that it was all wrong; that, somehow or other, he had made a mess of things. True, from the beginning, he had known no other life. In Town he had spent his pay, as the others did, and been called "a good fellow." And so it had been easy to go on, difficult to halt, and impossible to go back. But of that he made no excuse; he was not built in that way. He had failed. Yes, he knew he had failed; but he would carry out life to the end without a murmur

- of complaint, without the slightest outward sign of repentance or sorrow.

And Joe Ryan had never married-what burden he carried, he carried alone. And, when judgment is passed by the Great Unseen on those who have known the utter desolation of a loveless life, will not the hand which points our fate be touched with a special tenderness and forgiveness?

For the rest, there was much in Ryan's life 
to be recommended. He had been born in the backwoods, of a race who fight hard and die hard on the outer edges of the world, and he had learned his craft, from boyhood, in a stern school. No better lumbermen stepped the earth than those from his home on the Gauteneau River, none more expert with the axe nor smarter on the logs; and proud was their boast among the French-Canadian settlements on the Ottawa.'

Yes, Joe knew his work, as the best of them know it. He was among the chosen of the old hands, and, though on the wrong side of forty and not so active as of old, he could still compete with many a younger man. ...

Such, then, was my Riverman-this man whom I had picked up by chance at "The End of the Line," without introduction or recommendation, to be my sole companion on an unknown trail for five months.

I knew nothing of the man except that I knew his trade-which was a strong word in his favour -and it was long months after that I really knew him as I write of him. As he himself said: "You don't know me, I don't know you; and that's a risk on a big undertaking." But he took the risk, as he had always done, - the risk of mistake by a stranger at the bow paddle of the canoe on a dangerous rapid; the risk of "falling out" a hundred miles, or a thousand, from anywhere. ...

As for me-well, I was taking no greater risk than he was.

1 Ottawa River, of which the Gauteneau is a tributary. 


\section{CHAPTER II \\ OUT TO LAKE ÎLE À LA CROSSE}

I was setting out on a long expedition into the North, through little-known territory, west of Hudson Bay, on exploration and natural-history research. I had left my collecting "shack" on the Plains, from which I had roamed the rolling bluff-dotted country north of Qu'Appelle Valley for more than a year, and was now in the frontier settlement, which I have described, waiting for " open water."

On April 20 I had had an advice from the Hudson Bay Co. at Prince Albert, saying : "The ice in the northern lakes has not yet broken up. We will advise you immediately navigation opens, to enable you to go through by first open water."

On May 4, having no further advice, and impatient to get away, I left the plains on a dull cold morning, though the air and the scene had little promise of spring. Still were the long stretches of yellow grass and the bleak, darkcoloured poplar bluffs, unrelieved by the first fresh delicate green of budding vegetation. There was still frost in the ground, and snow in the hollows and sun-shaded nooks. But the call of the North was in me, and I would be off.

At Prince Albert, the northern town of the 
Province of Saskatchewan, I secured my canoea light 18-foot chestnut cruiser-and completed the carefully selected outfit which I was to take with me, and which had been minutely calculated, governed by the knowledge that I must travel light, and that I was setting out from the mercantile world for a year or more.

To anyone about to leave on a distant journey into country uninhabited, or habited only by primitive natives, the question of the essential things that are to comprise an outfit is of great importance, and therefore I give below a complete list of what I considered I must take, and how I contrived to pack it, in view of the nature of my work and the months of canoe and sled travel that lay before me.

\section{OUTFIT FOR EXPEDITION}

\section{HUNTING EQUIPMENT}

12-foot split cane fishing-rod.

12 bore shotgun.

-303 Ross rifle.

Mauserrevolverand belt sheath.

Revolver cartridges, 50.

Rifle cartridges, 100.

Shotgun cartridges, No. 10 dust-shot, 100.

Shotgun cartridges, various shot, 200.
Hunting knife and sheath. 8-inch mill file. Foot-rule. 48-foot length of rope. Field glasses. Pocket compass.

Camp axe. Few wire nails. Canoe pitch. Ball of twine.

Small red cotto bag, containing :

Specimen labels.

Address labels.

Indelible pencils, 5 .

Lead pencils, 5 H.B.

Wool for darning.
Needles and thread.

Safety pins.

Pins.

Buttons. 
Canvas dish-bag, containing :

Frying-pan.

Camp-kettles, 2.

Pail, medium size.

Reflector for bannock-baking.

Cups, 2.

Plates, 2.

Salt-holder.

Pepper-holder.
Knives, 2.

Forks, 2.

Spoons 2.

Can-opener.

Waterproof match-box.

Packet sulphur matches.

Axe hone.

Steel traps, 2.

Small blue cotton bag, containing :

Bait-hooks.

Fly-book and box.

Minnows, 2 boxes.

Reels, 2.

Spare line.

Gut casts, 1 box.

Gaff-hook.
Lead sinkers. Zine wire.

Brass wire.

Sandpaper.

- Beeswax.

String.

Blue box, containing taxidermal outfit:

File, small.

Nippers.

Brogue.

Scissors, 2 pairs.

Forceps.

Egg-blowpipe.

Egg-drill.

Brain-hook.

Photographic outfit :

Camera stand.

Developing tank.

Thermometer (in tank).

Extension back to camera.

Dark-room lamp.

Camera case, containing :

Camera, "Voigtländer."

Focal-plane shutter.

Collinear lens.
Black ink.

Skinning gloves.

Arsenic and alum, $3 \mathrm{lbs}$.

Glycerine and carbolic, $2 \mathrm{lbs}$.

Wadding, two $1 \mathrm{lb}$. rolls.

Small glass insect phials.

Mouse-traps.

Rubber bands.

Acid hypo, 6 tins.

Film-packs, 6 tins containing 8 dozen each.

Rytol developer, 8 bottles, 22 tabloids each bottle.

Telephoto lens.

Coloured lens, 3 grades.

Extension release, $30 \mathrm{ft}$. 


\section{4 ÓUT TO LAKE ÎLE À LA CROSSE}

Medicine chest, containing :

Blue pills.

Rhubarb and soda.

Quinine.

Carbolic.

Elliman's Embrocation.

Keating's Powder.

"Cut" plaster, 1 tin.

Bandages, 2 rolls.

Attaché case, containing :

Survey maps.

Sketch-book.

Large note-books, 2.

Rough note-book.

Handbooks on birds, 2.

Book on trees, 1.

Toilet bag, containing :

Brush and comb.

Shaving appliances.

Clothing outfit :

Blankets, 2.

Mackinaw trousers, 1 pair.

Red woollen shirt, 1.

Green cotton shirt, 1 .

Woollen jerseys. 3.

Underclothing, 1 suit.

Socks, 3 pairs.
Epsom salts, 1 tin.

Brandy, 1 bottle.

Mustard plaster.

Formaline, 5 per cent. solution,

for liquid preservative.

Mosquito oil.

Gun-oil.

Gun-rags.

Pocket dictionary.

Burns's Poems.

Wordsworth's Poems.

Rubber.

Mirror.

Candles, 3.

Tooth-powder and brush.

Soap, 1 cake.

Gloves, 2 pairs.

Towels, 2.

Soft hat.

Moccasins, 3 pairs.

Boots, 1 pair.

Trouser-belt.

\section{Tent :}

Silk tent, 8 feet $\times 10$ feet, which packs into very small bulk, and weighs but a few pounds.

Ground-sheet.

Grub for two men for two weeks (allowing that we kill fresh fish and meat en route) :

Flour, 28 lbs.

Bacon, green, $20 \mathrm{lbs}$.

Baking-powder, 2 lbs.

Beans, 12 lbs.

Peas, split, 4 lbs.

Prunes, 2 lbs.
Sugar, loaf, $2 \mathrm{lbs}$.

Tea, green, 2 lbs.

Salt, 2 lbs.

Butter, in tins, 4 lbs.

Pepper, 1 lb.

Cornmeal, 2 lbs.

Total weight, $78 \frac{1}{\mathrm{l}}$ lbs. 
Excepting the guns, rifle and rod, which were kept separate, the whole of this kit packed into five loads :

Food (two loads), 781lbs.

Box specimen case fitted with trays, $2 \mathrm{ft} . \times 1 \mathrm{ft} .3$ in. $\times$ $1 \mathrm{ft} .3 \mathrm{in} .$, and which carried some of the small bags in the top tray, 25 lbs.
One large brown canvas padlocked kit-bag, $58 \mathrm{lbs}$. One smaller ditto, $53 \mathrm{lbs}$.

By the method of packing certain articles in small bags and cases, as I have shown above, and attaching outside a label stating contents, one avoids confusion when any particular article is wanted.

The outfit above-noted was, perhaps, not perfect, but it contained most of the essential things and served me very well throughout my journey. In fact I would to-day make little change were $I$ again setting forth on a like undertaking.

The question of weight is of course the great consideration that must modify your choice when you have but the limited space of a single canoe to accommodate stores, as well as its two occupants.

It was an hour after dawn-the breathless air had lost but part of the wistfulness of night, the clouds hung grey and heavy with rain. Spring with a soft persistent hand was at last breaking down the iron grip of winter.

It was May 12, and, having roped the canoe and kit in a wagon hired from the lumber mill, we were setting off on the long trail and were making our way through spruce forest down the 
logging trail that terminated at the landing on the south-east shore of Crooked Lake. The trail to the Lake was very wet and heavy owing to the spring thaw, and the teamster, as he set out, was very doubtful of making the journey over the soft, frost-ruptured, slush-lain ground. However, spring was in our blood and difficulties looked small, and we started off in high spirits, accompanied by the parting good wishes of a small group of trappers and lumbermen who had, out of curiosity, collected to see the expedition setting out on its long adventure.

After a good deal of effort--indeed, after having twice completely stuck deep in the mire of the trail-the steaming, blown team drew up at the tiny landing, and our treasured possessions were deposited on the Lake shore.

The morning was now advanced.

Had we been about to enter the Garden of Paradise the day could not have been more perfect. The bright sun overhead shone in a cloudless, soft-blue sky, the air was vibrant with eager vigour and full of the promise of spring; and in our minds' eye, before us, in the path of our canoe, waiting our coming, was a great fair summer-garden of limitless range and promise. Small wonder if the pulse quickened joyfully and one inhaled with keen appreciation deep breaths of the fragrant, stirring, pine-perfumed air.

We slid the frail, new, spotless canoe into the water alongside the small rough-timbered landing, and praised her every line as children would a new toy, while over a "drop" from the flask 
she was christened The Otter and we drank to "success."

Then we bid farewell to the teamster, and turned our attention to the lake, and to embarking on our journey.

Though the day was fine the aspect of the lake was not reassuring: it was on the eve of rupture and change, but, contrary to expectation, the ice had not yet broken up in any extensiveness. We viewed the scene; Joe with a practised eye, I with half his intentness, and listening more, it must be confessed, to the tumult of the lake surface; for on the air, from the distance and near at hand, in haunting restlessness rose the persistent modulating sound of grinding, groaning ice-blocks agitated by the underflowing flood-water. It seemed to me as if the very soul of the ice-field was pleading to be set free, knowing in some mute sense that the holding grasp of winter weakened, and that the hour was at hand when its substance would cease to be.

I turned from those fancies, and conjectured with Joe the chance of finding a clear passage out. Around the landing, and across the head of the lake, there was open water-clear except for occasional detached lumps of floating icebut away down the lake, as far as the eye could see, there was nothing but a great sheet of dull, water-soaked, rotting ice, broken in places, and piled up where pressure had forced it to bulge and overlap on to a resisting surface.

"What do you make of it, Joe?" I asked.

"Not much," answered Joe; "We may or 
may not get through-better if we had delayed a week longer. The ice is fast on this shore a long way down, but as pressure is heavy and the freshet flood is rising, it has probably drawn off the shore on the far side, and an open channel may be over there. If it remains calm the ice will hold as it is, but wind from a contrary quarter would move the whole ice surface and send the pressure in whatever direction it pleased to blow. But here we are, we'll try her anyhow."

So we pushed off into the icy water and headed for the opposite shore across the head of the lake. Reaching there we found an open channel along shore, as Joe had surmised, and turned the canoe's head northward along it. All went well until we reached the cut across the lake which the incoming police party in their large canoe had opened up the day before. We had not long entered this narrow channel when a soft north-east wind began to rise and drift over the ice, and anxiously we saw the pressure begin to close the channel before us, and the ice rasped against the windward side of our light canoe. Briefly Joe uttered a word of warningfor we were in imminent danger-bid me seize an axe and break the pressure off the bows as far as I could, while he worked madly with his paddle in the stern. For an hour we laboured, more like madmen than sane men, while we could feel the canoe at times creaking and almost giving way to the weight of ice against her sides that threatened to break her into matchwood. Luckily the ice, in most places, was watersoaked and rotted, and by labouring incessantly 
with axe and paddle we were able to move on slowly, spasmodically, and change and relieve the pressure on the canoe when it threatened to sink us. 'We escaped through in the end, exhausted and wet, yet very glad to have escaped disaster to ourselves and to the irreplaceable outfit.

We saw then how foolhardy we had been to attempt the journey; how complete might have been the disaster at the very outset of our undertaking.

We had learned a lesson on overhaste, but, strange as it may seem, it is such uncommon experiences that are a part of the charm of the North-unexpected happenings, unforeseen dangers, forces that may lurk in flood waters, rapids, storms, night winds, ice floes, lowdropping thermometer and steel-blue cold, or in blinding blizzard. The ways of the North are manifold, and men cannot know her long before she bids them see her grim, unshakable strength, and experience a corresponding demand for daring and endurance.

The wind held in the direction it had sprung from and, working down the channel on the east shore, we had no further difficulty in navigating Crooked Lake. It was a long, narrow lake, trending northwards through forested hillcountry. The trees on the shore were mostly delicate, thickly branched poplars, not yet in leaf, and here and there a few green spruce trees, sometimes grouped together in clumps, sometimes solitary, while in places the forest had been thinned by fire and many skeleton 
trunks stood like grave marks or sentinels in their appointed places.

During our progress through the lake plentiful bird-life had been observed, and the woods were filled with little songs and call-notes of the feathered tribes that were daily coming in from the distant south to mate in their northern home. All of the common species I left unmolested, but secured four of the rarer types for which I had come: an Osprey, Wilson's Phalarope, and two Dowitchers.

Demonstrating the wonderful instinct that leads to the reappearance of bird-life in the North almost at the exact hour of vital change of season, a pair of Eared Grebes and a Loon (Great Northern Diver) were seen on Crooked Lake on May 12, when the lake had only yet a very small area of open water. They were kindred spirits in eagerness to be up and away with the first breath of spring.

On the evening of the second day out we had reached and entered the head of Crooked River. Here we camped for the night, emptying the canoe of her cargo and lifting her out of the water in case flood might rise overnight and damage her. Then we ate our evening meal, and rested, for the two long days of paddling, and kneeling in the canoe bottom, had found out unused muscles, and made us aware that we were not yet hardened to it.

And it was good to lie there idly and rest. The day had been glorious-spring almost breaking to summer; and we were satisfied now that the weather would cause us no further delay. 
As evening drew on we could hear, back in the woods from different points, the dump-dumpdump-dum! of a drumming Ruffled Grouse, quickly uttered, and closely resembling the sound of a motor-engine starting. A little later, carried to our ears across the darkening mask of forest, drifted the soft, musical hoo-hoo-hoo! of a solitary owl. We heard too, then, a few slow, rasping frog-croaks - a creature or two venturing to life, though the nights were yet too cold for them. Just as I was dropping off to sleep I heard a heavy moose splash ashore, having crossed from the opposite river-bank, and pass through the willows quite close to our camp.

The following eight days we continued onward, favoured, when we were on the move and not collecting, by fast-flowing flood water that hurried between wooded river-banks on their long, long journey to the sea, some 800 to 900 miles away, where the Churchill River-of which this was a tributary, via Lake Ile à la Crossefound outlet in Hudson Bay. We were two days on Crooked River, a stream about 130 feet wide, or less, that turned and twisted, as its name implies, but mainly flowed in a northwesterly direction. On the morning of May 16 we arrived at the point where Crooked River, twisting at this point in an abrupt astonishing south-westerly direction, empties into the northflowing Beaver River, and for the remainder of the journey to Ile à la Crosse Lake we continued on our way on the latter stream.

Beaver River was very beautiful. The banks in many places gradually sloped back from the 
stream to a fair height and were wooded chiefly with spruce and poplar. The poplars, with fresh-bursting tiny leaf, were now delicately green, against ground strewn with long-lain brown autumn leaves, and amidst symmetrical, formally erect, darker coloured spruce trees.

Crooked River and Beaver River have the reputation of being difficult to navigate in summer, as there are then many shallow stonefoul rapids; but in the big flood waters of spring-feet above the common mark, and covering most of the danger spots-we overcame all without serious trouble, finally running Grand Rapid, the last and heaviest rapid on this stretch of water, with a fall of about 25 feet.

Thereafter we found ourselves in easy slackening current flowing between banks which were low, and led on through a widening valley. Opposite Lac la Plonge, and towards its mouth, the river widens out and passes through a series of marshes and lakes before emptying into Ile à la Crosse Lake. Through those marshes and lakes the river turns and twists on its course between low, narrow banks which in many places scantily divide it from the flooded mainland on either side.

I have come rapidly down those waters in describing them, but in reality halt was made in many places to investigate the shores, or an inland lake, in carrying out research. During the ten days taken to cover the total distancewhich was some 140 miles-thirty-two specimens were collected between Big River and Ile à la Crosse Lake, and were skinned and carefully 
packed away. At the same time many hundreds of our more common birds had been under observation.

Having come rapidly forward, as I have said, I will return now and note a few of the incidents of the riverside.

Crooked Lake, May 13.

\section{Early Nesting Mallard}

To-day found a Mallard's nest containing three freshly laid eggs; the nest being in a cavity almost on the water edge in a low willow-covered bank. This pair had lost no time in mating and nesting, for ice still covered the lake. I marvel at their instinct: the wisdom that brought them hundreds of miles north across a continent, their time of opportune arrival set with the accuracy of calendar date: the wisdom that placed the nest so very close to the water's edge, as if the duck had knowledge that the river soon would fall. Some people might say it was accident, but the more one sees of nature, the more one ponders over that wisdom which is so often designated cunning.

\section{An Osprey's Nest}

Back a little way in the forest at the top of the " mast" of a dead spruce tree we came later in view of an Osprey's nest; a look-out over land and water without attempt at hiding. We ran the canoe quietly ashore, and went to investigate, while overhead, slowly circling, swung 
the great graceful birds that we had disturbed from the nest. Some 60 feet above the ground the dead tree had been broken off, and there rested the great heap of sticks that composed the Osprey's eyrie. I climbed the straight dead limb with difficulty, for it was of fair diameter, but I found, when directly beneath the nest, that it was of such great bulk that I could in no way reach out and above to the interior of the nest on top. I was anxious to secure the eggs, if there were any, and I tried from all sides to gain a firm hold on the nest sticks to draw myself outwards-but all to no avail, and in the end I climbed down to the ground unrewarded, and gave the quest up.

May 14.

Black Phase of the Broad-winged Hawk

To-day I shot a Broad-winged Hawk which was completely dark brownish black in colour. It was a black phase of this species. Such peculiarities occur, but they are rare, and one is glad to find them, in the same manner that one is glad to see a black fox or a brown-black timberwolf.

\section{Pike and Pickerel}

Pike and Pickerel are plentiful on this river, and we are securing them daily for food. Two Pickerel caught on small minnow to-day weighed $1 \frac{1}{2}$ and $3 \frac{3}{4}$ lbs. respectively. 
Crooked River,

May 15.

We meet two Crees

While skinning a hawk this morning, two Crees, travelling upstream, came into view. On sighting our canoe they stopped on their way and came ashore. They were going to Big River; they had some furs, they told us.

We gave them some food.

One was a weather-beaten man well up in years, the other a boy of about 18 summers. The elder man had a fine face, very pleasant to look upon. His eyes were sincere, and had an uncommon, permanent smiling expressionthough the whites of the inner corners were bloodshot, as seems to be common to all ; many fine wrinkles ran in between the eyes and the nose, as if his eyes had for ever searched over great distances. The nose was well chiselled and strong; the cheek-bones were high; the chin was firm; the forehead broad, and with two deep wrinkles across it. The colour of his skin was shining, deep yellow-tinged brown. The jet-black hair streaked down over the forehead, curled long and not ungracefully around behind the ears, and down across the back of the neck. The moustache and beard were scanty-a growth of a few coarse, untidy hairs. He wore Mackinaw trousers, loosely belted with a broad coloured, Assumption sash, and a black shirt. On his feet were moccasins that fitted like gloves, decorated with interlaced coloured straws on the foreparts. Neither spoke a word of English. 
A COMMON FRIEND OF THE VOYAGEUR

The Spotted Sandpiper is a very common bird on this river. We constantly disturb them as we creep downstream, and they rise before us, piping nervously, in pairs, or in threes or fours, from the river-bank. With flood waters

- high and covering all sand or pebble spits, they perch always now on dead limbs of fallen trees or uprooted willows which protrude over the bank or lie water-logged in the river. It is remarked that when flying these birds show a prominent mark of white across the centre of the wings, which is invisible when they are in repose.

\section{The Swallows are here!}

Tree Swallows are now arriving. The brief spring is already shortening; summer is almost here.

\section{Young OWLS}

Before the snows are gone the Great Horned Owls build their nests. To-day we found one. It was in a black poplar tree, not yet in leaf, situated about 20 feet back from the river bank. The nest was about 30 feet from the ground on a strong fork among bare limbs. It was not a large nest-small in comparison to the great size of this species-constructed with dead poplar and lichen-covered spruce twigs, and lined with rabbits' hair. In the nest were two three-quartergrown young, both very downy; the down on the larger one a beautiful buff-cream colour, the 


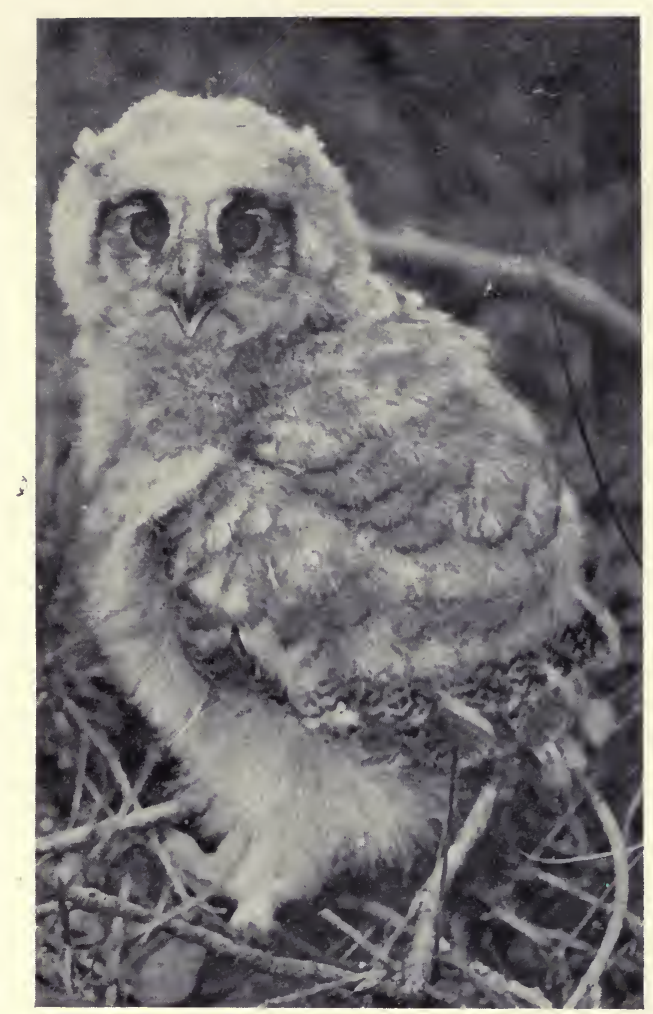

NESTLING GREAT HORNED OWL.

(Not yet half full grown) May 17, 1914.

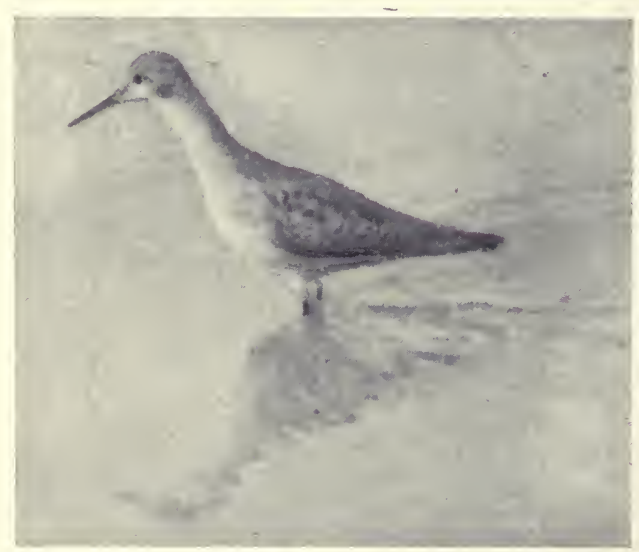

LESSER YELLOW-LEGS.

A fairly: common shorebird, loud-voiced like the European Redshank when alarmed. 

other more grey. They might, those weird creatures in the tree, have been elves of a Wrackham's pen, with their great round penetrating eyes and taloned fierceness. While I examined the nest, the parents perched in trees quite close to me and hoo-hoo'd continually in alarm and anxiety.

Finally we left the young to their parents' care, after some trouble to secure a photograph of them.

Beaver River,

May 16.

The American Goshawk

To-day found nest of this species and established identity beyond doubt by securing the female.

The nest was not very high up in a black poplar tree of a total height of some 40 to 50 feet. On approaching the tree the female Goshawk swooped down from it, and again and again passed close to my head, shrieking shrilly as she did so. The male bird was, meantime, nowhere to be seen, nor did he put in an appearance that day, or the following day, while we remained in the neighbourhood. The nest was composed of dead twigs and was lined with dry pieces of bark. It contained three very round white soiled eggs $1 \frac{11}{16} \times 2 \cdot 25$ in.-the full complement, as the female when skinned and dissected contained no further embryo egg-body.

To obtain a photograph of the nest's interior, Joe and I made a ladder by felling two young poplars 25 feet long and setting them against 
the tree next to the nest, thereafter nailing on cross-rungs up which to climb. Had we made the ladder complete on the ground, our united strength could not have raised the cumbersome, sap-heavy thing into position, nor would the nails have held it together, since the wood was green and soft. The ladder ready, the camera was slung by a cord from my neck, the distance to nest measured on the ground, and the camera set to focus before ascending. The position on the top rung was precarious - with the left arm tightly gripping around the tree trunk, to prevent my falling, I had only the free use of the one hand to bring the camera into position, remove the shutter, and touch off the release. However, gradually I worked the camera round from my back on to my right breast and then brought it to bear steadily on the nest by straining the cord back with my neck. After some trouble, I secured three exposures. It took some time to do all this. What was my reward ? None at all! Just a record of disaster ; for my reference to this particular film-pack, which I was then using, reads : "Rest of film-pack spoilt through films jamming and not coming out properly."

And that was the only occasion on which I have ever seen a living Goshawk or the nest of that species.

Beaver River, May 18.

LONG DAYS AND MANY LABOURS

Arose 4 a.m. Came on about twenty-five miles. Lay down to sleep at 9 p.m. A seventeen-hours 
day, which is about our usual day - the principal exertions, our ever-onward search and travel; and skinning specimens and preparing food when we ran ashore at our night camping place.

GREeN LEAF SHOWERS FORTH ON WINTER-BARE TREES

To-day has been very fine and the sunshine brilliant, and on the river-bank the leaf-buds of the poplars and willows are bursting, and the trees in a few hours have become beautiful with liberal show of minute ornament of purest emerald green.

\section{Scarcity OF Wild DUCK}

There is on this river, so far as we have gone, a marked scarcity of wild duck. They are here much less plentiful than on Crooked River. We are now on the main Hudson Bay Company's route from Green Lake to Ile à la Crosse post, and it may be that they are less common here because this river is more often disturbed by passing voyageurs.

Beater River,

May 19.

WARBLERS ARRIVING

Many warblers are to-day in evidence for the first time. 'With the advance of spring they are feeling their way north. Groups of them were observed among the willows, restless and plaintively calling as if still in course of migration. 
WE LEAVE THE RIVER AND VISIT SMALL LAKE

After travelling some distance to-day, we viewed, beyond the low bank on our right, a small inland lake on the east of the river. Through field glasses it was seen that this secluded water held abundant waterfowl, so we decided to portage the canoe overland to it, and spend the remainder of the day there. The borders of the lake were grown with tall yellow marsh grass, while down to the lake shores crowded compact, sheltering forest, except on the river-side, which was open marsh. Here and there a gaunt, dead, storm-bruised tree stood in the water, landmarks to remember, and the perching places of a small colony of Bonaparte Gulls which were among the many birds on the lake. Black Terns were here in large numbers, flying swallow-like in the air, but, unlike the swallow, plaintively and fussily shrieking over our heads in protest against our approach. Coots were numerous and many duck: Mallard, Pintail, American Scaup Duck, Golden-eye, and Blue-winged Teal. Though ducks appeared scarce on the river they were common enough here. From among other and more uncommon varieties I secured seven specimens, and felt well repaid for having halted and turned aside to this favoured and fascinating habitat of wild fowl. None of the birds on the lake were nesting. They were either still on their journey northward or had but lately arrived in old haunts. I skinned late into the evening at our camp by the shore of the lake, while coots, in scores, splashed noisily, and chattered among the reeds close by., Once or twice, a busy musk- 
rat swam smoothly across the calm water, from shore to shore of an inlet, with nose and tail on the water's surface and mouth packed with a fresh gathering of reeds.

Beaver River,

May 20.

Joe traps small Mammals

I carry two steel traps and some mouse-traps, for collecting purposes. The larger traps afford Joe, my riverman, much amusement, for he has trapped furs and has all of a trapper's enthusiasm, and love of speculation as to the possibilities of a catch after his set is made.

After the evening meal is over off Joe goes to look for signs of animals and make his sets. Having found a place to his liking, you may watch him plan to outwit his quarry, place a trap just to his liking, cover it with great care, stake it down, and finally lay his tempting bait - a fish, a fish head, or a part of a bird carcass. In the morning, yesterday, he had captured a Ground Hog, and this morning a Skunk.

\section{Nearing Ile à la Crosse}

To-day we came down the lower reaches of the river, and, against a light headwind, stole out from its mouth on to the large lake of Ile à la Crosse. 'We had come through low country latterly, where long marsh stretched away north with the river course as far as eye could see. There were lakes on either side, deep blue and wind-ruffled, and with yellow marsh bordering their areas; low timber country on the far 
distance of land; willows on the river-banks with wave-shaded tops of fresh new green, and, on the east shore, small occasional bluffs of poplar. Overhead an equal feeling of unbounded vastness and beauty-far off white pillowed clouds in a soft blue sky.

\section{Marsh Hawk. Birds very local}

To-day I observed a single Marsh Hawk. This is in a way remarkable because it is the first one I have seen since leaving the prairies, where they are very common. But birds in Canada are often very local. Their favourite haunts are contained within great areas, and they do not apparently roam far beyond them except in their migration north and south. One may live years in one place and never see a single bird of a species that may be fairly common a hundred miles or more away in country of a different type.

In noting here those incidents $I$ have done so to give an impression of daily occurrence, the like of which continued for many months while travelling over 2,000 miles through Far North territory. Hereafter I will not continue day to day description of the country, its scenery, and its wild life, but will take you boldly to the subject of the chapters which deal with the most interesting incidents of the expedition. 


\section{CHAPTER III}

\section{SEEKING THE SANDHILL CRANE}

ONE evening in May found us quietly moving along the east shore of Lake Ile à la Crosse, when the sun was lowering in the west and a soft, damptempered haze hung around the bottom of the dome of the sky. We were paddling along easily, enchanted in a measure, by the scene and sound of our unbounded surroundings. The setting sun still lit the shore ahead, enriching with the colour of gold the fresh young leaves and the white trunks of the cottonwood trees, till they were fair and fantastic as fairyland should be; while, on the lake, moved the low murmuring lap of gentle waves coming and going in company with the light northern breeze, and that made a laughing trickle as they broke on the prow of the canoe. So intense was the mystic hush of evening, and unpeopled northland, that we almost felt guilty that we would be discovered in our quest-that quest that was not for fairies, but for something almost as elusive : the haunt of the Sandhill Crane.

To-day, to-morrow, or the next day, we hoped to have luck and find that which we were searching for, but who could tell!

Until an hour after sunset we kept on, listening, hoping that the lone call of a crane might 
be borne down to us on the breeze-But no! nothing gave us hope-nothing; and the day was done.

Seeking night camping-ground we ran in where the shore was bad, for we had to make a landing somewhere on a shore composed of gravel, and granite and sandstone boulders. But the ingenious Joe jumped ashore, and while I held out in deep water, cut and laid a bed of spruce boughs at the water's edge, and on that the frail craft was smoothly grounded, emptied of her load, and carried ashore as wind was rising.

The country behind the east shore where we camped, and which we were searching along, was generally low and, although the map in my possession was blank, we knew it must contain many forest-bounded lakes, absolutely secluded from the disturbance of red man or white; and it seemed possible that if any cranes were nesting in the interior they might at some time come out near this greater sheet of water, and perhaps, if seen, betray the secretive locality they inhabited. To go haphazard into the forest to search would be as vain as "to look for a needle in a haystack," requiring many months to attempt, without any certainty of any success.

Two days later found us groping in the forest, searching for unknown, unnamed water, through country that had not even a game path to show us our possible destination. The evening before we had heard a crane call, clear and unmistakable, from high in the sky over the forest. The call had been repeated; had grown nearer and louder until, at last, we had seen the great winged bird 


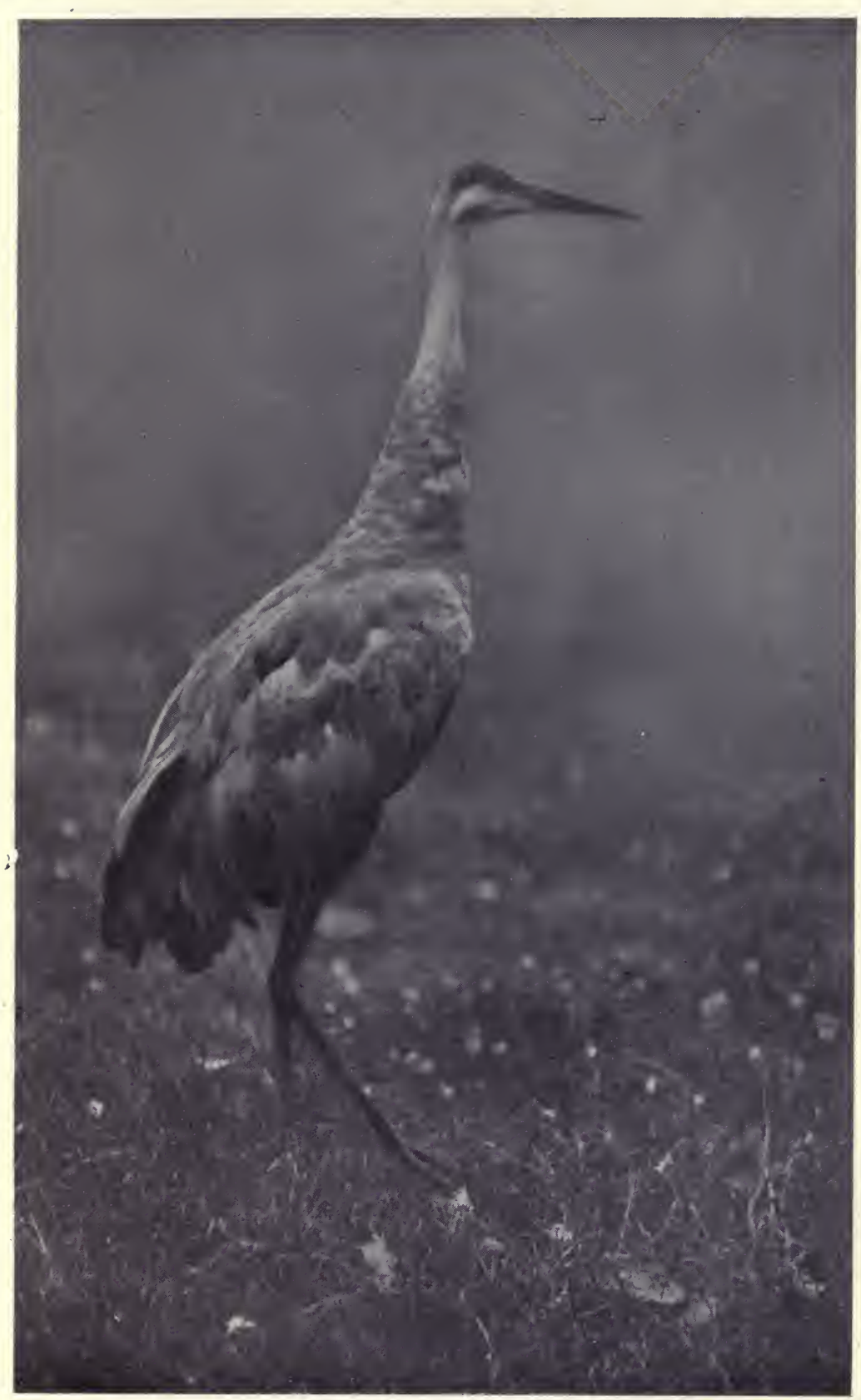



come into sight, and, ultimately, pitch on the shore of the lake. Breathlessly then we had watched and waited, for it was as if we were searching for gold and were feverishly near to it.

For a little time the bird had pecked among the gravel, then risen heavily, got started in speed and equilibrium, and sailed away over the forest straight back into the east. The bird's manner of going had the decision of one returning to settled haunts, and we felt sure that if we could find a marshy lake somewhere in the area where the bird had flown we would be very close to the real centre of our search.

So were we groping in the forest-east for a long distance, then traversing roughly northeast and south-east. In our search we came on more than one lake and had to make wide détours in some cases to get past and beyond them, but in none did we disturb the secreted crane, and at the end of the day vain had been our search through belts of crowded forest and muskeg bog, where foothold was precarious and stepping laborious.

Throughout the day we covered a large extent of country and were disappointed to have seen nothing of bear, moose, deer, or other animals indigenous to this territory. But where areas of forest are great and closely grown it is really seldom that one sees big game in summer-time. In fact, at this season, one might often be misled to believe that there are none. However, that would be a rash assumption: there is game in plenty, though to-day was a blank one, and all that we disturbed was an innocent, awkward- 
moving porcupine, feeding among the branches of a poplar tree, and a brooding spruce grouse which we flushed from beneath an alder tree, where six eggs reposed on a shallow gathering of dead brown leaves.

Over the evening camp fire we were forced to wonder if, after all, we had made a mistake, and were to suffer the disappointment of an error of judgment. Joe, no longer actively young, was feeling tired and stiff after the long day on the trail, and was plainly sceptical and inclined to be disheartened and give up. I, on my part, was prepared to doubt my judgment of the day before - the bird, after all, might have been a solitary one without mate or settled haunt, an outlaw male roving broadcast where it willed, free and restless as the four winds of the wilderness.

In the early morning, while the dew yet lay white on the undergrowth, and mists lay cloudlike over the muskegs in the hollows, we were out of our blankets and preparing to strike camp.

We had decided to give up : to go back to the canoe, and continue on the long north trail.

'We were eating our hasty breakfast-tea, bannock, and a slice or two of fried salt porkwhen suddenly we both started to our feet, each, in excitement, exclaiming quite needlessly "Lord! what was that?" as clearly and closely the call of the lost crane vibrated through the morning stillness. The sound came from the north-east, no distance ahead. Astonishment and delight lit up our faces; though the incident decisively showed us how near we had been to utter fools, in 


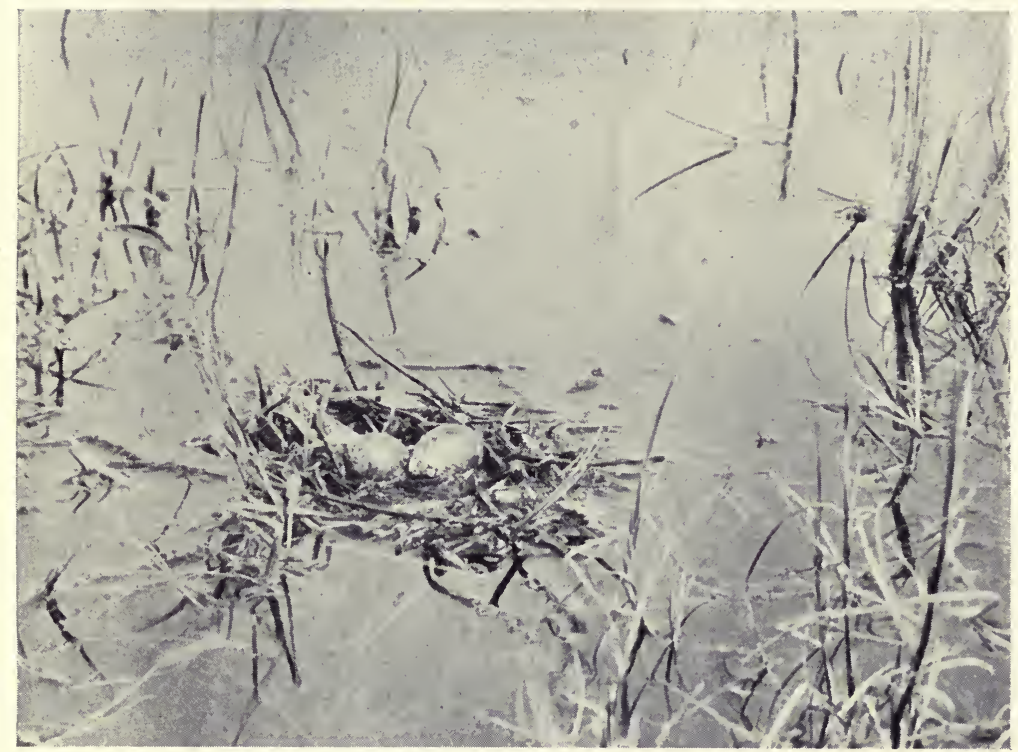

NEST AND EGGS OF BLACK TERN.

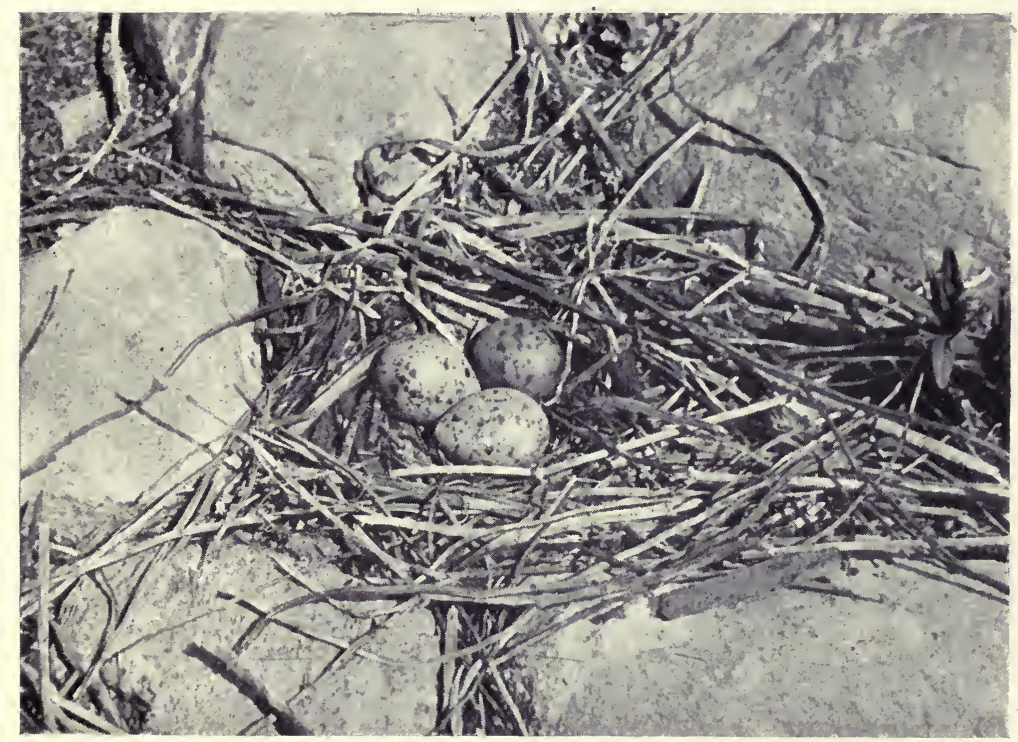

NEST AND EGGS OF COMMON TERN. Rocky Island, in an inlet bay above Samoy Lake. 

giving up when within reach of our rare and elusive quarry.

A few minutes sufficed to finish breakfast and start on the trail. Our search did not meet with immediate success, and by eleven in the forenoon our eagerness was rebuffed and considerably abated, while we were still hunting for the lake that held the secret. But at last we had our reward, in all its fulness since it had been so difficult to attain, for, about half an hour later, we came on a small marsh-bordered lake, and there, when we stepped out of the woods into view, two great Cranes arose from its interior, uttering their call of warning, above the peevish screaming of a large colony of Black Terns, as they swung wide and high over the lake, disinclined to depart. Here indeed was the lake we had been searching for, this forest-locked sheet of water, lying calmly at our feet full of meditation and reflection, and unaware that it held for us great treasure. The lake was angular, and had one small island in the middle on which grew an ill-thriven tree or two. On all shores there were extensive reedmarshes, broadly stretching out into the lake, where water-depth was shallow.

We explored along the shore of the lake for some distance, disturbing bird life of many kinds as we went, but ultimately decided that it would be impossible to search thoroughly for the crane's nest without the aid of our canoe. This would mean a very long arduous portage, but Joe, my sturdy old backwoods-man-as keen as I on the quest-himself suggested it, and made light of the toil which he was setting for himself. 
To begin with, our task was to blaze and clear a trail back to our camp on Ile à la Crosse Lake ; so we set out on the back-trail, seeking the line of clearest passage, and cutting out saplings and overhead branches whenever they would interfere with a clear way for man and shoulder-high canoe. At intervals a clean white "blaze" was sliced on the homeward side of a spruce, pine or tamarac tree, to show clearly our way ahead when we came to return with the canoe. Our small hand-axes struck out quickly and unerringly as onward we pressed.

By late afternoon a long distance had been cleared and blazed, by constant toiling, and we thought we were near to our old camp. Here we were at fault, however, and for an hour could not find our proper course nor come out un the shores of Lake Ile à la Crosse. Although we did not know it at the time, we had got too far round to the north-not much, mind you, but just enough to change the whole aspect of the country and lead to confusion.

At dusk, after crossing a spongy muskeg bog with difficulty, we came out on the inner end of a far-reaching inlet bay of the lake. Joe was put out by this time and candidly lost. I, assisted by the compass, was convinced we were north of our camp, but for once Joe was "at sea," and could in no way back up my opinion.

However, after a rest, my counsel having prevailed as to direction, we cut south-east into the woods again.

We had not been on the fresh trail more than an hour before we found ground we knew and 
camp. We were not long in rolling ourselves in our blankets; and slept the faultless sleep of well-tired and healthy hunters.

Prewarned by constringed wispy grey clouds. of the previous evening, we awoke in the morning to find a storm had burst.

For two days we were delayed, while a heavy south-west gale scudded angrily over Lake Ile à la Crosse and made it impossible for us to canoe up-shore to the inlet bay where our blazed trail terminated. Had we known at the outset that the storm was to last, we would have cleared an overland trail to the inlet. But that. would have entailed considerable labour, so we waited for the change of weather, trusting to luck, and it turned out that luck was not in good humour.

On the third day we were up at 4.15 a.m.if my watch was right-while the golden glow of dawn was in the east, and the sun was still hidden behind the dark peaks of the spruce-tops. In the crisply cool morning-for the thermometer registered only 4 per cent. above freezing-we started up-shore in the canoe, disembarked at the inlet, and commenced the long portage inland.

You know how a canoe is carried?... The paddles are lashed to the narrow cross-barswhich are the seats of the canoe-in such a position that when the canoe is upturned and hoisted over a man's head, the head slips between the paddle stems just before the spatulated blades, which thereupon descend comfortably on to the broad shoulders of the carrier. In lashing the paddles into position for canoe portage they are longitudinally arranged so that the canoe will be 
fairly evenly balanced when being carried-if anything, a little more weight should be proportioned to balance behind rather than in front. A chestnut canoe is a heavy man-load, somewhere in the neighbourhood of one hundred pounds, and it is wise to load up carefully and comfortably before starting on an undertaking that tries one's strength to the utmost before the other end of the portage is reached.

Meantime, to return to our undertaking, we had been labouring for hours along the blazed trail, and it was not until the afternoon that we reached our destination-the lake that contained the cranes.

After a brief rest we launched the canoe: assuredly the first craft since the beginning of time to intrude on the placid waters of that unknown lake, set deep in forest seclusion.

We eagerly commenced our search for the crane's nest, urged on by sight of the birds who wildly flew from before our neighbourhood, uttering once or twice their curious call. Our search was a long one; all the marsh shores were examined in vain, and not until evening, when on the island in the lake, did we find the nest. Here, on a marshy point on the south side of the island, to our great delight, we came on the long-concealed nest-a large platform of gathered marsh-wreck built on the water surface among reeds; and therein two large oblong eggs of medium buffish sienna colour (perhaps finely speckled) and with spots and splashes of darker colour.

Now in the case of rare birds' eggs you doubtless know that it is essential to establish their 
identity beyond any shadow of doubt if the record is to receive recognition and be of scientific value. This is usually done by securing one or both of the parent birds. But in this case I had a double interest in wishing to secure the parents : for all along I had never been sure of the identity of this pair of birds-their apparent colour bothered me. Observing them through Zeiss field-glasses they appeared buffish brown tinged in colour, not the leaden slate-grey of the Sandhill Crane as I knew it in autumn in the plains. (The red on the forehead was very bright, and the neck more greyish than the rest of the specimen.) Was theirs strange plumage of the Sandhill Crane, or could they be Whooping Cranes ? Here was uncommon interest, and I was more keen than ever I had been in my life before to secure those specimens. ${ }^{1}$

Joe and I soon planned a method of outwitting the cranes. I, with my twelve-bore gun, hid among the willows on the island, while Joe put out on to the lake in the canoe, paddled across it, and landed, and hid himself and canoe in the forest to make believe that we had taken our departure.

I had not long to wait in my hiding-place before my excitement grew intense. The great cranes called, one to the other, appeared in the distance, and soon were swinging overhead, examining the

1 Since this was written I have had opportunity to look over the half-dozen skins of the Sandhill Crane which are in the British Museum. One of those had, on the forebreast, decided sienna-brown colouring, and I now conclude that the specimens above referred to were this species, but of exceptional sienna breast plumage. 
lake beneath. Again and again they passed over the island where I lay hidden, lowering in their flight, but not low enough - they were very wary ; provokingly suspicious.

At last, as one of the great birds came sailing straight toward me, I thought it within long range and took my chance-Both shots rattled on the great bird, but alas! it but faltered in its flight for an instant, and passed rapidly away from my discomfited sight.

I felt all was over now-the great chance irrevocably lost; but hoping against reason, I waited on until dark.

Neither bird returned, and sadly I put off for shore when Joe came for me.

We left the nest and eggs untouched on the island, deciding to sleep the night on the lake shore and visit the island again in the morning in the forlorn hope that the cranes would in the meantime return.

We spent a comfortless night, cold-since we had no blankets-and tormented by mosquitoes.

Next morning we were early on the lake, and moved quietly toward the island, while no cranes were seen or heard, foreboding ill for our enterprise. But we were not prepared for the culminating disappointment that awaited us at the island-when we came to the crane's nest it was empty !--the eggs had gone! Where? We could not tell; we could only surmise that rats, crows, or the cranes themselves had destroyed them or carried them off.

It was all a terrible disappointment. Great hopes sustained until the final hour; then nothing 
OUR CULMINATING DISAPPOINTMENT 43

but wreckage. For two years I had dreamed of finding the nest and eggs of this species north of Prince Albert, and this result when my dream seemed true!

Like everyone else naturalists have their successes and failures. This was my dark day.

Before leaving the lake we spent an hour among the colony of Black Terns that were just commencing to nest, and obtained some photographs of the few nests that contained their complement of eggs. 


\section{CHAPTER IV}

\section{ON THE GREAT CHURCHILL RIVER}

IT is difficult to measure the distances one travels in passing through new country, so one seldom attempts it. When the question arises of travel about to be undertaken, or that has been accomplished, one falls back, as a rule, on what maps one possesses to scale off as best onc can on a minute scale the straight distances as they are there shown. But such map measurements are at best but rudely approximate, for seldom indeed can one follow a land or water trail directly from point to point, as one assumes the course on the map. Indeed, if one surveyed and laid on paper the actual course of a primitive canoe $^{1}$ in navigating a lake, while keeping land in view and avoiding the unsheltered open lake on which it would spell death to be caught in one of those rapid rising storms of wind so common to the country, one would be astonished at the line that would zigzag and curve in its progress towards its objective, for it would in all probability take along shores of jutting headlands and through bewildering groups of island, that ever

1 I speak of inland waters that have grown old in their own deep solitude, where stout power-driven sailing-craft are unknown of the kind that could surge ahead through all winds and currents and on any course, aided by chart and ship's compass. 


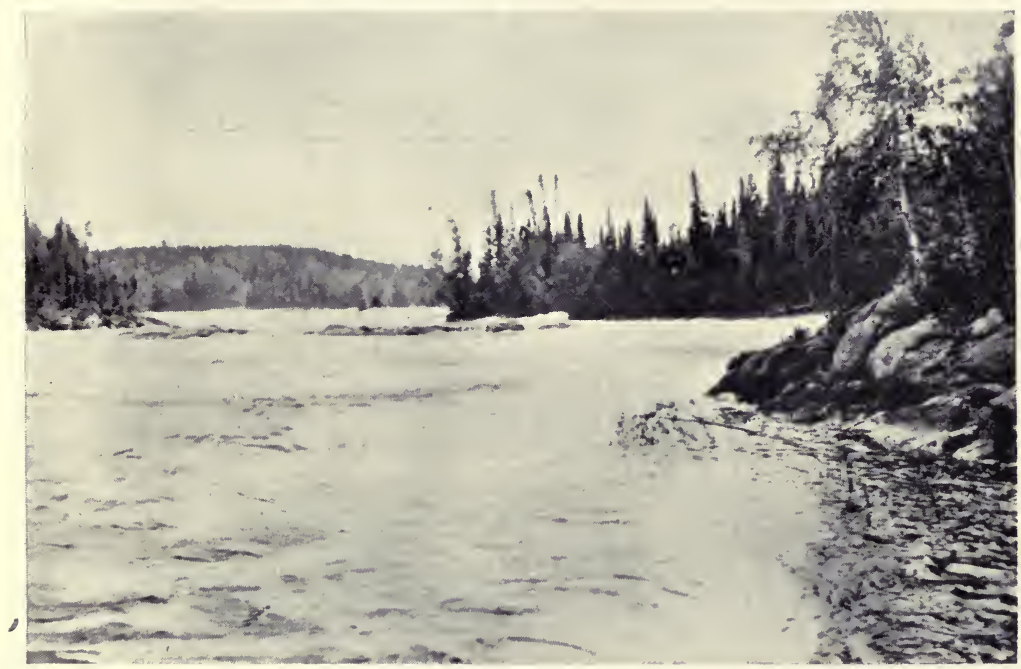

GATEWAYS OF MAGNIFICENT RIVER BETWEEN THE LAKE EXPANSIONS.

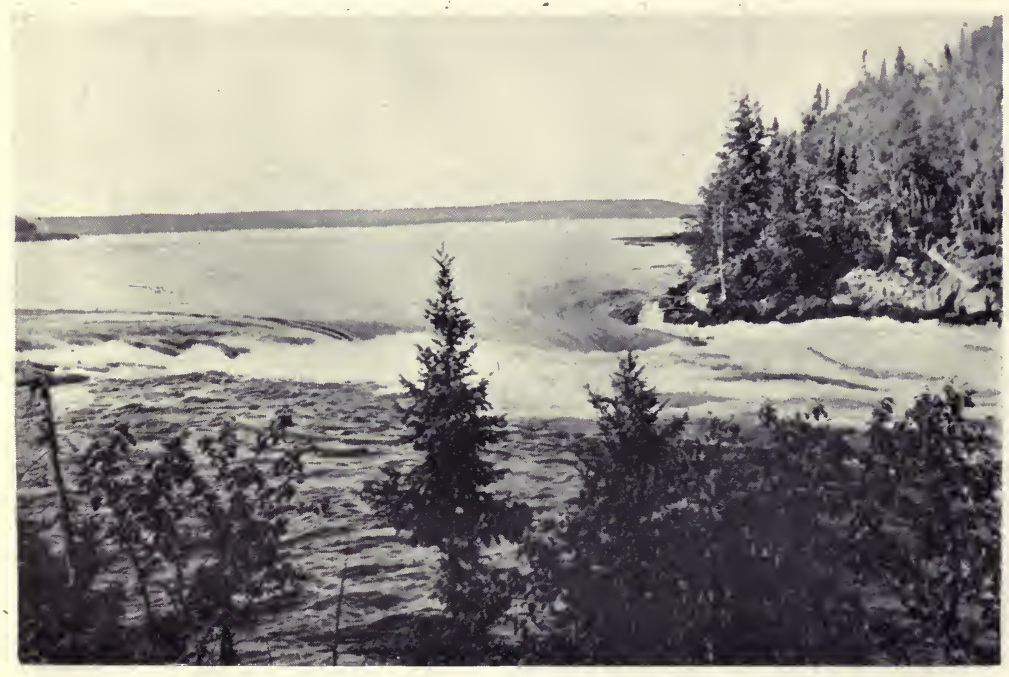

A RAPID.

Scene of sound, commotion, and colour. 

interrupt and change the route of travel; and add many hours' labour to the patient voyageur. Over land it is the same; one works forward to a distant objective, for ever on the look-out to avoid the rougher going-thick undergrowth, swamps, muskegs, and such natural obstaclesand endeavouring to obtain the most comfortable and progressive route that the local conditions of the country offer.

Maps show the distance that I have canoed on the Great Churchill River-or "The English River" as it is locally called-from Ile à la Crosse Lake eastward to its junction with Reindeer River, to approximate 276 miles ; while beyond the point of my departure from it it continues easterly another $\mathbf{5 4 0}$ miles before it empties into the sea in Hudson Bay. This is sufficient to make clear that it is a mighty river in length, as it is also mighty in breadth and volume of water.

Throughout its course the Churchill River is an extraordinary series of wide lake expansions linked together by gateways and glens of magnificent river where waters gather in indrawing volume to enter, and hurry, and tumble, and roar in their wild escaping onward, ever onward to the next lake, and the next, in their incessant, time-set journey to the sea.

On the section of the river on which I travelled there were no fewer than sixteen large and beautiful lakes, ennobled by solitude, rich in the undefined and the mysterious of the Unknown : each resembling the other in that they were gems inset in the one type of fair green forest country 
end of the portage path, which was but a faint, almost invisible passage down the forested shore, used once a year, perhaps, in this thinly populated, almost depopulated land, by some three dozen Indians journeying to the rendezvous of the official Treaty Party at Ile à la Crosse to draw Treaty money, and hold a big powwow.

The following morning we resumed our journey and were soon to learn that we had rapids and typical hard river voyaging to contend with. During the morning we encountered three rapids. The first we ran, and shortly after leaving it behind we passed, on the north shore, the sandbars which lie at the mouth of the Mudjatick River. The Mudjatick, or Bad Caribou River, noteworthy because it affords a possible passage, though a hard one, to Lake Athabasca, rises in the height of land north of latitude $57^{\circ}$ and flows south about eighty miles in a shallow winding channel before it joins into the Churchill River. Thereafter followed other two rapids both too dangerous to run, so at each we let the canoe down the less turbulent water close in to the south shore : a process we accomplished by wading hip-deep, at.bow and stern of the canoe, over the uneven, bouldered, hole-dented bed of the stream ; leading the canoe slowly and laboriously downstream, holding against the rude strength of the downpouring passing current.

About midday, after a strenuous morning, Joe and I landed. I had secured three museum specimens and nine mallards' eggs en route. We lunched on the eggs-finishing the lot at a sitting. I assure you that if one works hard one 
eats heartily in the North. It was June 2where we lunched on shore Pin Cherry Trees were in blossom and Wild Strawberries, and tiny purple Violets were in flower; charming colours before the great background of evergreen forest.

In late afternoon, when nearing the head of Pelican Rapids, we came quietly downstream on two moose standing in the cool water, browsing contentedly on a bed of Water-lilies in the solitude of a sheltered bay. Had it been open season, or had meat been necessary to our existence at the time, they would have fallen easy prey. When our scent was borne to them they left the water, and vanished in the forest.

Before sundown we portaged Pelican Rapidsa roaring, tumbling force of water that one heard rumbling in the distance long before one came upon it. It was a wild, angry rapid, typical of many on this mighty river-agitated waves when eager escaping waters rushed together through the narrow, bouldered gateway; long, swinging swells curling at the crests and breaking in silver foam; great waves rising over boulders and rocks, and plunging into the depth beyond. Below the entrance, ere the force died out in the great deep pool at the bottom, were boiling whirlpools; and backwater eddies-swinging round to the sides of the main stream and back into the head-waters of the angry turmoil. On the shores were dark rocks tilted at all angles and broken limbs of trees stuck in crevices where high water had lodged them. Everywhere the waters were blue in the sunlight except where they broke 
in silvery foam-an inspiring scene of sound and motion and colour.... And there was an old friend : the Tennessee Warbler, whose kind particularly haunt the shores of rapids, singing joyfully of summer and boundless activity, seemingly in competition with the prolonged purring sound of the rapid, which clearly pleases him.

Next morning we passed the great marshes at the entrance to Pelican Lake-marsh that teemed with duck in the full pride of brilliant summer plumage. Mallard, Pintail, and Shovellers were the most abundant, and Green-winged Teal and Golden-eye in lesser numbers. In addition to those birds there were great colonies of Common and Black Terns nesting among the marsh-reeds, and many Yellow-headed Blackbirds-hoarse, shrill-voiced reed-birds, piebald in aspect, with their black and yellow markings of sharp contrast.

The air was dotted with swinging groups of birds we had disturbed, winging their way forward, then backward; while the water and marsh held many more. It transpired, as the months passed and we travelled on through lake and river, that this lake (Pelican Lake) was recalled as the one containing the greatest abundance of waterfowl. It held, however, one disappointment-there were no pelicans-at least none were seen. Possibly they once inhabited the locality, as the name of the lake implies, but now have departed.

Pelican Lake was very irregular on all sides, with long bays biting deep into the mainland; also there were many wooded islands, mostly of fair elevation, standing well out of the water. 
Small poplars grew chiefly on those islands and a few white birch, while here and there a group of spruce and pine showed darkly, and above the tops of the other trees. Willows bordered the narrow beach of light granite stones, which marked the line between water and soil.

On Pelican Lake we encountered difficulties. Crossing it in the canoe we faced a heavy head wind and struggled against large waves which the heavily laden canoe rode badly, for she rose stiffly to the crests of the waves and pitched heavily into the hollows between. We shipped more water than was comfortable and, once or twice, shipped it in ugly fashion until we feared damage to our canvas-protected stores, which lay packed in the centre of the canoe, if not a trifle anxious for our own safety. Finally, about 3 p.m., we were able to reach an island, and put ashore to wait until the wind should drop.

At 6 p.m. the wind had moderated and we were able to go on, and reached the east shore of the lake. But then again we were in difficulties, for along those shores we searched until dark without finding the "blind" (hidden) outlet from the lake.

It had, altogether, been a disappointing day of hard work and little progress.

Next morning early we found the channel through to Primeau Lake, but again, during the day, we were in trouble, for in the afternoon we toiled up a deep bay which in the end blankly terminated, and it took us until evening to return to the position of our mistake. On a great many waterways of the north, if without an 
Indian guide who knows the territory, it is a grave problem to determine what to do when confronted with two, or even three, long channels of water, to the terminus of which the eye cannot see, and decide which is the one which holds somewhere in its shores (secreted, perhaps; in yet another bay off the main bay) the river outlet. Sometimes, on the dead water of the lake at a shore point, or at a stone, or at weeds, it is possible, on close examination, to find the slightest of down-flowing current passing the stationary object; and then one may be positive that one is following the right course. At other times it is one's good luck to hear the faint rumble, like a rising puff of wind in the trees (which one must be careful not to confuse it with), of a distant rapid or waterfall, and know that where it arises is the river. There is yet another sign which sometimes gives one comfort when current and sound fail, and that is some mark of Indian travel on shore : a willow or tree from which an axe has robbed some branches and left the wounded ends, the black ash, or a burnt stump, of an old camp-fire, or, best sign of all, a discarded teepeefor those elementary, pole-framed, cone-shaped habitations of the native nomads are seldom, if ever, erected except somewhere on an Indian main "roadway." But there are times when all those signs are wanting and one must simply trust to Providence when confronted with the puzzling irregularity of the shore.

The following morning, June 5, we found our course soon after pushing off. Below Primeau Lake we ran Crooked Rapid and part of Knee 
Rapid, after making a short portage over the rocks at its head where the first inrush of water broke angrily over a rocky dip in elevation. We had not long left Knee Rapid when a Black Bear was sighted on the north shore, wading in the water in search of fish, as is a common habit with them in summer. The canoe was run ashore, and as the animal ambled into the woods, for it had seen or scented us, I tried a long shot at about 300 yards, but failed to bring it down.

The greater part of the day was spent travelling a zigzag course through Knee Lake, a long, extensive sheet of water, and we camped toward sundown well up to the north-east end, where should lie the river outlet.

Knee Lake, like the others, was very irregular in shape, and contained many islands. The rough hilly north shore was often less densely wooded, and, here and there, ranged along the lake for a considerable distance, were bare grass-hills scantily scrub-grown.

During the afternoon we came on a pair of Bald Eagles nesting on a prominent point on the west shore of a side-channel on Knee Lake. The huge, twig-constructed nest was on the top of a decayed spruce tree, and contained one wellgrown young bird.

To-day was a lean one for securing specimens. I note that it was remarkable that I saw no hawks in this territory, and had not seen one since leaving Lake Ile à la Crosse-though up to that time I had seen a fair number and had secured one or two skins. It bears out that which I have always experienced in Canada--that birds are remarkably 
local, principally because, in my humble opinion, in such a vast country, they are free to select ground of nature most attractive to their habits of feeding, and most remote from their natural enemies. I do not include man and gun as "natural" enemies, for they have invaded the country after the habits of the birds were inherent. Large numbers of some species, such as geese and cranes, have had the wisdom to seek new haunts north of the line of civilisation. All of the edible species that remain within the settled country, such as Sharp-tailed Grouse, Pinnated Grouse, Ruffed Grouse, ducks of many species, geese, and cranes - all are diminishing, some even threatened with extinction, like the buffalo and the Prong-horned Antelope; and that though the legitimate shooting season is open but for two brief weeks in the Fall (autumn) of the year.

With extracts from my field diary I will follow out the incidents of the remaining days we voyaged down the Churchill River; extracts which it is my hope will continue to serve to bring before the mind's eye of the reader something of the varied, wholly outdoor and untrammelled aspect of this great northern waterway.

June 6.-Morning dull, threatening rain, high wind from north-west. Astir before 5 a.m. Cooked breakfast, and, as customary, the one meanwhile struck tent and packed canoe ready for embarking, while the other was employed over the fire. Mosquitoes were very troublesome when we came ashore last evening, and worried us all through the night. At all times at this 
season mosquitoes are in great numbers, but when they are particularly bad-swarming and biting with unshakable persistency-it is a certain sign that rain is near. Those insects, and black-. flies and sand-flies at times, are the bane of summer travel in Canadian north territory. Out on the water they never trouble one, but on shore they pounce on one from the vegetation that is there, and are a constant jar to one's full pleasure. One should never set out, as I thoughtlessly did, without mosquito curtains; I would never again overlook to prepare against them. True they carry no disease, but in numbers and capacity to torment they far outstrip the malarial mosquito in Africa (Anopheles) in my experience.

We reached the east end of Knee Lake between 9 and 10 a.m. There were there, close to the exit from the lake, a small log cabin or two, on the north shore and on an island. Those were completely deserted of Indian or halfbreed : no sound was there, no contented smoke curled above the thatched roof to give welcome to lonely voyageur hungry for companionship and the sound of human voices. The inhabitants had gone, the men taking with them their womenfolk and their children, even their dogs. They had gone, perhaps, to meet the Treaty Party, perhaps to pitch their teepees at some favoured summer haunt where fish and fowl and beast were sufficient to feed them plentifully.

Invariably those log cabins of Indians are built-as those here were--on a site remarkable for the long stretches of water it commands : the sharp bend of a river, or the junction of two 
rivers, is most often chosen, where the hunter inhabitant can obtain, without moving from his door, an extensive view down at least two great watercourses, and see, perhaps, the passing of worthy game, and, seeing them, would then set out in chase.

At this point of Knee Lake there was a pair of ospreys nesting; magnificent, masterful birdsthe "Fish Eagle" of the country. Their nest was on the top of a dead jack pine on a drear hillside scorched at some not long past date by a runaway bush fire. There grew there now, among the charred and blackened débris, the little adventurings of new green growth; an uprising of little living things about the feet of the grave, grey, dismantled masts of trees that were dead and but monuments now of lives once lived.

When we were nearing the osprey's nest the male bird was seen to approach, against the wind on powerful wings, carrying in his talons as food for the sitting female a small pike about twelve inches long. This fish he carried not broadwise to the wind, but held parallel to the body, and with the head facing forward, so that it offered little resistance to the wind.

About 10.30 a.m. we passed the mouth of Haultain River, a stream from the north, about 300 feet wide where it empties into the Churchill River over shallow sand-bars. Here, in the marsh west of the river mouth, I spent some time observing bird-life. Five specimens were collected during the afternoon, and three nests of eggs were found.

It commenced to rain after midday and we got 


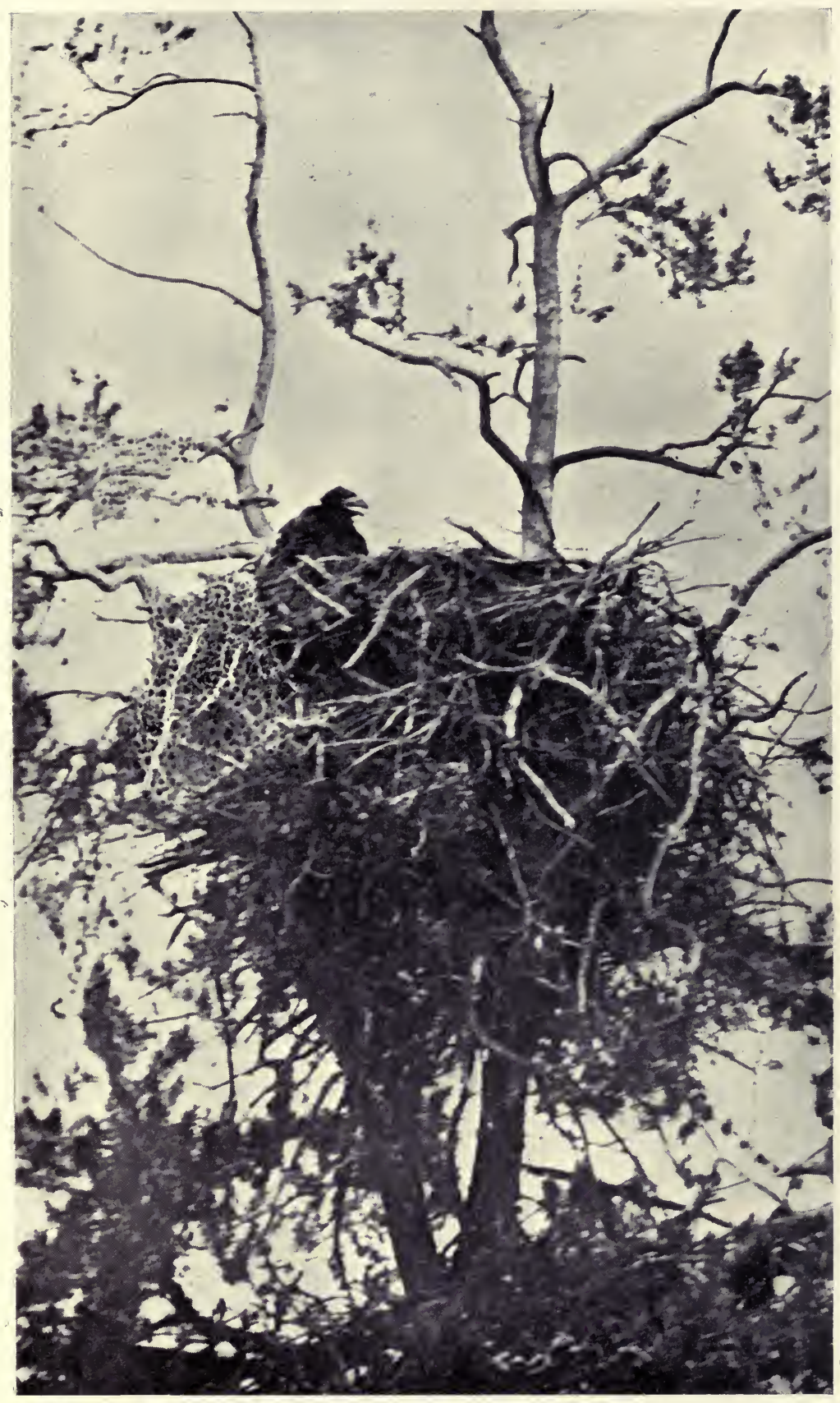

A BALD EAGLE'S EYRIE. 

miserably wet before evening. During the day the following birds were observed: Leconte Sparrow, Swamp Sparrow, Yellow-bellied Flycatcher, Yellow Warbler, Tree Swallow, Redwinged Blackbird, Belted Kingfisher, Snipe, Bittern, Mallard, Shoveller, Golden-eye, Bluewinged Teal, Holboell Grebe, Black Tern, Crow, Raven, Osprey.

June 7 (Sunday).-Awoke this morning after a miserable night passed on water-soaked ground in damp blankets. The activities of the mosquitoes on the 5th were sure forecast of rain, and so rain had come. It rained all day, and we did not attempt to move on but sat tight within the shelter of my small silk tent. I skinned the specimens I had collected yesterday, while Joe did his best to nurse a spluttering fire before the tent-door for the cooking of meals. Rain can be a most disconcerting element when canoeing and camping-out in this fashion, far from any settlement; a steady downpour will very soon find a way into every conceivable corner, no matter how well you have fancied you have taken precautions against it, and the result is that before long you sit among your far-carried, dearly valued possessions and see them in a state of half ruin before your eyes. Then only sunshine can lift your depression, and, in spite of your unpleasant experience, when Old Sol breaks through again you find yourself gaily arranging your possessions before its heat, and looking out on the world with a freshened optimism. Rain was, however, by no means a constant tyrant, for we experienced a beautiful summer 
of sunshine with days of rain a rare exception.

June 8.-Morning overcast after a night of heavy rain, but the heavy clouds cleared about 10 a.m. and the day thenceforward was bright and pleasant; the air crystal-clear as the sparkling water, the whole North world pure with the intense cleanness of virginity.

To-day we passed down the rapidless stretch of river between Knee Lake and Sandy Lake: a stretch sub-named Grassy River on account of the waterway for some distance wending its way, in three separate channels, through broad green marsh. The chief incident of the day was the finding of a colony of nesting terns on a low, plantbarren, wave-washed island, full note of which is given in the subsequent chapter of "Field Notes." While on the island, some time was spent photographing nests, and, thus delayed, we were still short of Sandy Lake when night approached and necessitated our pitching camp on the river bank.

June 9.-We breakfasted in rain, and struck camp, to continue our canoe journey under the same discomforting conditions. An hour after leaving camp we emerged into Sandy Lake, and throughout the day voyaged through it. Sandy Lake bore out its name, containing many low broad points and bays of beautiful sand. Indeed, so clean and white were the shores in many places that the lake was thereby of pleasing fresh aspect in comparison with those already navigated. Here, too, and on account of the composition of the beach, shore birds were found more 
numerously than anywhere previously, and I collected ten specimens; among them a pair of Sabine's Gulls, of which I saw three. These are noteworthy, for they were the only specimens of this species encountered throughout the expedition, and possibly they are quite rare in this inland territory. Further west, some two hundred and fifty miles, Ernest Thompson Seton and Edward A. Preble made an expedition in 1907 down the Athabasca River and adjacent waterways, and in their list of birds observed do not record having seen a single specimen. ${ }^{1}$

Late in the afternoon, close to an island in the north-east corner of Sandy Lake, we came on a small settlement containing fourteen inhabitants. Here (in the rude, unkept clothing of an outdoor exile), we found a white trapper, by name Hans Madson-a Danish-American married to an English-Cree halfbreed woman. Not an old man, this ruddy haired Dane of perhaps five-andthirty, yet were the customs of his race wellnigh erased and his disposition imbued with the habits and mannerisms of his redskin associates : only in colouring and speech did-trace of his origin remain; so far had he grown into the likeness of his surroundings. His cabin was empty of every luxury of food, and his eyes lit hungrily when opportunity was given him to receive a portion of sugar and prunes in exchange for dried moose meat; for his daily food was little more than dried meat, and fresh or dried fish, cooked without seasoning and eaten without vegetable or bread of any kind. He was undis-

1 The Arctic Prairies, by E. Thompson Seton. 
guisedly delighted to see us, and told us we were the only whites he had seen since the Fall of the previous year, when he had been out to Prince Albert. He begged us to camp the night near him, and this we did, sharing with him as real a European meal as scant stores could furnish, much to his satisfaction and gratitude.

The boom in black fox farming was at its height in 1913 and 1914, and every good fox that could be trapped alive in the wilderness was being caged and sent east to Prince Edward Island for breeding purposes. Like every other white trapper in the Dominion of Canada, Hans Madson was "fox crazy": smitten with the mad desire for great riches, as men are swept off a sane balance who join in a great gold rush. He was obsessed with the thought of digging out dens of priceless black and silver cubs, or the offspring of black or cross parents. Now, however, the cub season was over, and his chance of success, for the time, was gone. He had had no great luck-a few reds and cross foxes he had taken-but, undaunted, still he talked of the rare animals he had seen on frozen lakes and in snowed-up forest, and of others his Indian friends had reported; and he dreamed with true optimistic sporting keenness of the possibilities of success when the next early spring should approach.

June 10.- In the early morning we bade a goodbye to Hans Madson, who looked on with melancholy visage at our departure: God knew when next he would see a white man! Not likely another to pass his way this summer, nor any summer, for he had pitched his camp off the route 
of the red man's trail-off such trails as rare, adventurous, self-exiled wanderers of the white race turn curiously along one or two days in a score of years. In olden days Indian tracks from the Reindeer River-Foster River territory radiated from the Hudson Bay post at Ile à la Crosse, and this stretch of the Churchill River was a well-used main route, but later, a shorter and easier north route developed to the Churchill, from Cumberland House via Sturgeonweir River to Frog Portage, and from Prince Albert via Montreal River and Lac la Ronge to Stanley Mission Post.

Soon after we had bidden farewell to Madson the canoe entered the short stretch of river that led on to Snake Lake and we ran Snake Rapid, the only rough water on our course to-day. Thenceforward the day was occupied in travelling through Snake Lake, a lake of some twentyone miles length from western to eastern extreme. The shores of this lake had some prominent formations of vertical sand-bank, or small cliffs; especially on the north-east shore. During the day much bird-life was observed, and some nests and eggs collected at points we landed at. Toward evening we camped well to the east of Snake Lake within view of a solitary deserted winter post of the Hudson Bay Company. This day witnessed a favourable change in the weather, for about noon the rain, which had been with us for the last four days, gave place to clearing skies and periods of sunshine. Charming was the evening at our night camp:- late western sunlight rested with golden richness on the eastern 
wooded shores, while below the curving, changing shore-line the broad lake water lay becalmed and wholly placid and blue, and a perfect mirage of leaved forest, scarred banks, spotless pebbles, and dainty sandpipers was reflected on the immediate lake margin. Overhead - with similar instantaneous sight, and marvellous quick-changing flight of Swift or Swallow-swinging, plunging, rising through the cool, balmy, rain-purified air, flew a pair of Nighthawks, feeding on insects the while they emitted their hoarse, grating call, which is associated with summer evenings anywhere in Canada; though perhaps most familiar of all to those who camp outdoors by lake or forest. Such sounds, and a few others, are inseparable from Canadian wilderness; typical in their own country as the call of the Curlew or peevish Lapwing on the dreary, wind-swept, highland moors of the British Isles: such the maniacal, laughing cry of the Loon (the Great Northern Diver) heard on nearly all backwood freshwater lakes; such the eerie wolf-howl of the Coyote on the western plains.

June 11.-A day of perfect weather-very pleasant for canoeing. Progress to-day was marred by our missing our true course when east of the deserted Hudson Bay Cabin. There we entered a long false bay to the south of the turn beyond the Post and had three hours' fruitless paddle to and from its blank extreme before we were again back on an open course, where we discovered a slight sign of current to definitely point the way. About 3.30 p.m. we entered Sandfly Lake, a lake of lesser size than Snake Lake. This proved 
again to be a lake containing a great many islands similar to Shagwenaw, Pelican, and Knee Lakes of those we had thus far voyaged through on the Churchill. Some of the islands were of fair elevation and were wooded, others were lowlying surfaces of rock and boulders with a scant, ill-thriven growth of grass. We landed at a group of the latter where large colonies of terns and gulls were nesting. Of those I made observations and notes, and collected a few rare shorc-birds. Before departing we gathered some fresh eggs to augment our food supplies, counting them a great treat since they were a change from our regular diet of bannock, salt pork, wild duck, and pike. Pike and black and red Suckers were the only fish I caught on the Churchill River-no trout were seen; not even on Trout Lake.

This day I observed a single Chipmunk-noteworthy, as I had not before seen this pretty little animal on the Churchill. A Porcupine was also seen landing on the shore after swimming across the expanse of water above Sandfly Lake. He proceeded to climb a poplar tree to feed on buds and leaves. This was the first occasion on which I had seen this species in the water. It appeared not to relish its immersion, for it shivered with cold, and perhaps with fear, when it landed.

June 12.-We reached the exit from Sandfly Lake in the afternoon and passed into swiftflowing river where bad rapids were encountered and canoe navigation became impossible. This meant hard labour, but, as it was all in the day's work on travel of this kind, we stuck to our task, with the result that three rapids were overcome 
and an open course lay before us at camping time. At the first rapid--Pine Portage-we waded into the water and let the canoe slowly down a shallow branch of the river on the north side; at the second-Birch Portage-we portaged the canoe, stores, and specimens overland through the wood on the south shore; and at the third-Fall Portage-we again portaged, but only over a narrow twenty-yard rocky neck, to evade the fall that was there, for the water below was navigable.

To travel, as we did, without an Indian guide to lead exactly over the recognised route-which is invariably the quickest and least laboursome route, and the outcome of knowledge handed down from one generation to another-meant that when no human trace could be found on shore, such as an old portage path, when navigating rapids, or where friction of feet had slightly whitened a vague line over an exposed platform of rock, we simply had to act on blunt individual judgment in accomplishing our journey; and blundered on occasions and gave ourselves extra labour. On rare occasions we saved labour, as in this case, for a small map I possessed stated that there were four portages at this part of the river, while we only actually made two, though a third would have been necessary had we not succeeded in letting down the canoe at the top rapid. However, travelling guideless as a rule increases the labour and risks, and certainly means loss of time; yet, even so, there is something most attractive in attaining to complete independence, complete freedom from reliance on others, which is most typical of the primitive 
spirit which the North makes known to you, and approves. And, beyond the pleasure it gives to be able to go where you list through the wilderness, and risk what you list, the extra labour you undertake has behind it, as all labour that is difficult must have, a spiritual satisfaction and reward: for among red men or black in British colonies, the prestige of our race is surely upheld by those who, when occasion arises, can stand up alone, endure alone, and accomplish alone, admitting no weakness to the eye of the critical native. Many an Indian expressed great surprise at my travelling unguided through their boundless country. Foolhardy it must have seemed to them who knew the difficulties and dangers; yet none called me a fool. Rather were they ready to be my friends - not on account of myself, but because their simple imagination painted me like the adventurous White Chiefs of our earliest settlement, who wandered far and had great knowledge, and whom they were willing to serve as subjects.

June 13.-Having secured some specimens yesterday-among them an adult Northern Bald Eagle-I was busily employed skinning all morning.

After lunching we again pushed forward, our course swinging well into the north-east up the lake-like expansion that lies between Sandfly Lake and Black Bear Island Lake. Passing the neighbourhood of the mouth of the Foster River - a river of considerable size flowing from the north-no sign of its outlet was seen, and I have since learned that that was because it empties 
into the Churchill in the bottom of a deeply inlet bay.

Toward evening we entered Black Bear Island Lake through its maze of channels which flow between the large islands that block its entrance and obscure extensive view. Like the shadows of a big problem were those islands which were crowded in and almost made prison walls about us, leaving us anxious to solve the riddle that would discover the doorway of escape and give again the freedom of the open road. Nowhere do I recall such another eerie, shut-in scene as this. But in an hour or so we had worked our way through to more open water and pitched camp for the night on the north mainland of the lake, viewing, across the shimmering, dead-calm water, and over the tree-covered contour, a glorious sunset among grey and white clouds that had retired to the horizon from the great blue open sky.

No less ungenerous than on the days that have gone before are my entries and remarks this evening on mosquitoes and black flies. They give no peace when on shore: they truly are the curse of summer travel in Canada.

June 14.-A lovely morning; calm, and clear, and warm; the continuance of a spell of fine weather without drawback to voyaging. We did not leave in the canoe at once this morning, but explored in the dark forest behind camp among fallen limbs and trunks lying about on the rough, hillocky, moss-covered underbed of the woods. Many of the trees were picturesquely lichen-grown with whitish, close-clinging plant, and with scattered tufts of hairy, moss-like, pale- 
green plant. At the edge of the forest was an eighteen-inch growth of green grass and weeds. Forested hills sloped upwards from the north shore of Black Bear Island Lake, and at the summit in some cases an outcrop of rock and large boulders protruded prominently. The lake was some fourteen miles in length, and while we remained on it we never quite forgot its somewhat frowning, shut-in aspect. Even birds seemed to shun the neighbourhood, for few were seen, and I recorded it the worst I had so far travelled through in that respect. It has not been common with me to hear the red squirrel's chatter in this territory, but here I heard one to-day. While speaking of creature sounds, I am reminded that it was on this lake that I first noticed the absence of frog-croaking in the evenings, and it was not until reaching Stanley Mission on June 23 that they were again heard. Unfortunately I was too busily employed with other subjects to investigate their apparent absence from this area-a stretch of about seventy miles of watercourse. No black bears were seen, and in supporting its nomenclature this lake was as disappointing as Pelican Lake. Probably, when the course of the Churchill was mapped, a black bear was seen on one of the islands of the lake, and therefore the name-a name selected on the spur of the moment, without perhaps grasping any very great and permanent characteristic. On the other hand, I, in my haste onward, might easily miss such a characteristic, did it in reality exist, therefore it is merely a passing personal impression that $I$ at present record. Had I been 
the original surveyor I think I would have chosen "Eerie Lake" as name for this strangely silent expansion of dark water, wherein were closeted ghost-like citadel islands, and wherein I never quite threw off the impression that I had intruded on a sanctuary of spooks and fairies of long-past ages.

June 15.-Day again fine. Noonday sun high overhead, giving the broad earth fulness of summer, and its living season of growth. How blithely it lifts the spirit! How different this to the sun's low, short circuit in winter over land then dormant!

Characteristic of the country are the conepeaked tops of Black Spruce on the sun-lit hillsides, their branches drooping down a little in extending horizontally outward; in this respect differing from the White Spruce, which is more straightly outgrowing.

Passed the rapid at Birch Portage about 3 p.m. and entered Trout Lake. We let the canoe down through the troublesome current at the top of this rapid and ran the remainder. We camped for the night on Trout Lake.

It is now twenty-four days since we left Ile à la Crosse Post.

Joe to-night caught a pike weighing seven and a half pounds when trolling with a small blue phantom minnow.

June 16.-Spent till noon to-day looking for right course on Trout Lake. Yesterday headed out north-easterly in following the small survey map in my possession, but found no outlet. Today, in the forenoon, canoed down the east shore, 
poking into all side-inlets-but without avail, and we lunched at Birch Rapids, from whence we had started yesterday. From there we set out due north, and found our course through.

About 2.30 p.m. thunderstorm and squall broke over us when in mid-lake, and gave us a rough time until we reached inshore, where we lay up until evening; then travelling onward, when the wind went down, late into the night. We shipped a lot of water in mid-lake when struggling against the great waves that arose, and at one time feared for the safety of our craft, but finally we got through with little more than a thorough wetting to our persons, the stores and specimens saved by the tarpaulin which I always have laced over the canoe-centre against rain, or spray when running rapids. Such a tarpaulin, and a light platform to keep the kit raised off the canoe bottom, are essential for protection against wet on long, rough journeys of this kind.

Saw first two blooms of Wild Rose or Briar to-day.

Dragon-flies are now about the shores, and have been in evidence for the past three or four days. They commonly fly back and forth at height of the tree-tops (say 40 to 50 feet) or else very low around the roots of the willows on shore; to rest on occasions out of the breeze on the sand in the bays.

Daily I note ornithological observations, and continue collecting specimens, but these are omitted here as I deal with them in a later chapter.

June 17.-Up at 3 a.m. and away early with the desire to make up for time lost on Trout Lake. 
Morning very dull and chilly, with wind from the east-it looked like rain, but the sky cleared later in the day and there was none. In early morning entered the north channel of the two riverways which run past the large island which lies between Trout and Dead Lake. Here we had to pass four rapids; at the first two, Trout and Rock Trout Rapids, it was necessary to run ashore above and portage the canoe and kit overland to quiet water below-laborious work over the rough ground with the huge loads we piled on our backs to lessen as far as possible the number of journeys back and forth on the portage trail. After we had finished at the second rapid I put up my rod and fished the deep, swirling pool at the top with a small minnow, hoping that I might see trout. Here I hooked two great fish, not trout, alas! but pike. The first one finally broke, taking the whole of my tackle; the second, after some twenty minutes' play on my trout rod, I landed-a pike weighing $18 \mathrm{lbs}$., measuring $3 \mathrm{ft} .5 \frac{1}{4} \mathrm{in}$. in length. Hitherto, until that canoe voyage, I had always looked upon pike as an unclean, poor-quality-food fish; but on the Churchill River, and elsewhere, we caught those fish almost daily at times, and thoroughly relished eating them. Of course, living as they did in clean cold water, those fish were of particularly good quality, and, besides, real hunger cures many a fanciful aversion.

Resuming our journey we ran Light Rock Rapid and the nameless one below, having some exciting moments on the latter, which was stony and very rapid, and somewhat dangerous, 
but through which our canoe travelled headlong, like the wind, unscathed. And so out to Dead Lake, the shores of which were high and rocky, timbered as usual with willows, poplar, spruce and pine. Camped for the night well to the north-east of Dead Lake.

During the day, on a marsh in the river, we saw a fox prowling, searching for fish or waterfowl. Unaware of the canoe for a few moments, the animal allowed us a full view of it, then, as it saw us, but a glimmer of rusty red and whitetipped brush as it leapt ashore with great bounds through the marsh and into the forest. It is not often that a fox is thus seen during the day in summer, in the open, in country which is for them one vast wilderness of forest cover.

June 18.-This morning we paddled out into the south-east sun, while before us were the silver-glinting, sun-lit waves that ran merrily with a moderate breeze. The short remaining distance on Dead Lake was soon covered, and we again entered a connecting link of river-the link between Dead Lake and Otter Lake. Here we spent all day getting past rapids which had principally to be portaged.

At Great Devil Rapid, the first of the rapids here, we encountered tough opposition to travel. Portage was necessary-a portage of excessive length, which gave us incessant labour until lunch-time in effecting the transport of the canoe and stores down to the foot of the dangerous water. The portage was sixty-four chains in length, over rough, uneven ground, through forest that skirted the banks of the river. Joe, 
heavily laden, made three trips over this portage, and I five, for, fitting in our work to save time, as we always did, I went back for a load while Joe prepared lunch, and again for a final one when he washed up and packed our belongings in the canoe. Therefore the distance Joe travelled on that rough portage amounted to almost five miles, and mine to eight miles-all over rough country ; and one-half of those distances, the down-trail half, accomplished while carrying heavy loads. Thus you can conceive the nature of hard river work which the voyageur has to contend with -work so hard that I think it can truthfully be said that no white man can accomplish it who is not accustomed to it. Hardened though I had been with previous outdoor life on the Saskatchewan Plains, I well remember how tiny my first packs seemed in comparison to Joe's $60 \mathrm{lbs}$. to $100 \mathrm{lbs}$., and how I perspired and laboured with them, and how impossible it seemed that I should ever be able to carry such a load as he did. Yet to-day my loads could equal his-so can man harden his will and muscle to any task in the face of necessity.

Overcoming Great Devil Rapid was our morning's work, but there our difficulties were by no means at an end, for we found we had yet two more portages to make this day, each necessitating the unloading of the entire contents of the canoe, the carrying of heavy loads to the bottom of each portage, and, finally, the carefully balanced repacking of everything into our frail craft, so that we would, each time we embarked, enter the water snugly compact and weather-worthy. 
Below the third portage we camped for the night, after having there cut and cleared a portage pathway through the forest, as we failed to find any old track made by Indians. The river above this rapid broke into more than one channel, and apparently they evade this last rapid by taking through, or portaging, at one of the other branches. No one could run the water we encountered in a canoe.

Fished with fly in river to-night, but saw no sign of trout. Caught 5-lb. pike on minnow.

Shot two specimens-a Northern Raven and a Grey-Cheeked Thrush.

June 19.-Mosquitoes and black flies were particularly virulent last evening; it was calm and close-omens of a weather change, and sure enough all to-day it rained heavily. In the morning we decided it was too wet to travel on account of portages ahead where stores would be soaked were we to uncover them for pack transport overland.

So we stayed in camp all day, I skinning and looking over my case of specimens, Joe cooking meals over a spluttering fire, and baking a few days' supply of sour-dough bannock from the sack of flour.

The $5 \mathrm{lb}$. pike caught last evening was gone in the morning from the tree on which it had been hung. A bear had taken it, for claw marks were on the bark where the thief had reached up to plunder our larder. I could well imagine the brute in the dead of night contentedly licking over its lips when it had finished the meal as it ambled away into the forest, well pleased at 
scenting and finding such easy prey; perhaps almost laughing up its sleeve at our impending discomfiture.

June 20.-We awoke to find the rain-storm past, and, 'refreshed with yesterday's rest in camp, we made an early start, embarking at 4.30 a.m.

Soon the great easy-flowing river narrowed, and we heard ahead the unceasing rumble of falling water-we were coming to Otter Rapid. Arriving there, and after making the usual careful survey of the agitated waters, we decided that no likely channel presented itself that could be run; therefore we would attempt to let the canoe down along shore very close in to the bank. Into the water we got, clothes and all, till it swept high and forcibly against our thighs, one grasping the canoe forward, the other astern. The shore proved rough to let craft down : strong side-swinging inshore waves and eddies caught and strained the canoe, and almost swept us off our feet as slowly, feeling for precarious foothold, we carefully stepped and stumbled along over the rocks and boulders and pockets of the river-bed. Nearing the foot of the rapid we made a short portage across a rocky point and in doing so cleared the last stretch of troublesome water. Soaked to the skin were our lower bodies, from our jacket pockets down; but we never changed into dry clothes, for we were inured to this sort of thing, and garments were few. We shivered somewhat on occasions when we first got into the canoe again after being in the water, but soon wind and sun, and the heat of our 
bodies, dried up the clammy, uncomfortable wetness. Hardly a day passed that we kept dry throughout.

Below Otter Rapid was Otter Lake, and by lunchtime we had almost completed the distance on this nine-mile expanse of water, which was full of high, wooded islands distributed in great profusion, as on other lakes which I have previously described.

About 2 p.m., on entering the river channel between Otter Lake and Rock Lake, we encountered more rapids. Here again we took like deer to the water and let the canoe down Stony Mountain Rapid; then passing on to Mountain Rapid, which we had to portage. Below this latter rapid we cooked the evening meal; but did not camp, for we were nearing Stanley Mission, and, excitedly eager for the society of mankind after our long, lonely spell on the canoe trail, had agreed to keep on and attempt to reach the post to-night. A twelve-mile sheet of open water lay before us through Rock Lakeno more rapids between this and the Post.

Memorable were the last two hours outside Stanley Mission. Southwards down Rock Lake we paddled in the full content of a perfect Northern evening, praying wind would not rise to detain our eager passage, lilting snatches of half-forgotten popular songs, snatches of Joe's French-Canadian songs of the Ottawa River, even snatches of the old Scotch airs of boyhood were amongst our mutual répertoire this evening : each timidly singing with rusty, unskilled voice, but each voicing surely the lifting of spirits from the 
gloom of lonely days now that we anticipated meeting kinsfolk. Without fault, as luck would have it, we steered a true course down the lake, which appeared less irregular and confusing than many of the others, and late in the evening, after hours of unceasing paddling, we came upon narrowing shores which promised the foot of the lake and the location of Stanley Mission. The light in the western sky lay low on the horizon; the shores to the right and left darkened to solid blackness; the air and the water were alike becalmed. In through the last long stretch of lake glided the solitary canoe, our two figures, dark in the dusk, rocking slightly as we flicked the paddles methodically in and out of the water with easy, almost careless strokes-action that was habit after months on the water. At last two light-coloured dwellings gleamed dimly on an inland bay to the south, promise at last of the settlement we sought. Into the bay we glided; noiselessly we stole inshore with the stealth peculiar to canoeing. Eagerly we listened, but no human voice was there to give us welcome -we had not been observed, and apparently the inhabitants had gone indoors to sleep. . . . A disconsolate sled-dog, on a distant shore, gave forth a long, coyote-like howl ... then, again, deadly silence. We stopped paddling before an Indian teepee that was just discernible on the dark shore and called out. No answer came.... Again I spoke; footsteps shuffled, and there was a murmur of gruff voices within the teepee; then an Indian hailed us, but in response to my question, asking direction to the white trader's 
dwelling, he made no response-he did not understand my tongue.... Down the shore a door creaked, suspense a moment, then a clear woman's voice rang out in English. We were dumbfounded. Was there a white woman here ? There must be. . . . ${ }^{1}$ Clearly the voice directed us. How sweet it sounded here, how welcome the assuring instructions ! - for we were dog-tired after our long day (eighteen hours in all), and eager to land and camp.

June 21, 22, and 23.-During those days we camped at Stanley Mission Post; the 21st was a Sunday, and we took things easy, on the 22nd much time was spent at the Hudson Bay Company's post, replenishing supplies, while on the 23rd it rained heavily, and unfortunately delayed our restarting for a day.

Throughout the period we were at Stanley Post our chief care was to protect our tent and belongings from the sled-dogs of the settlement. They were a downright pest, so bad that Joe and $I$ had to take it in turns to stay at home and sit on the doorstep, so to speak, to defend our belongings against their attentions. We lost a few little things to begin with, in spite of our care, but the culminatng offence that brought our wrath down on them was when on the night of the 23rd they raided our tent while we slept and devoured six loaves of bread which the halfbreed woman at the Post had that day kindly baked for us as a particular delicacy, and which were

1 Next day we found there was a lady teacher at the Mission engaged in educating dusky halfbreed and Indian children, and that it was she who had spoken to us. 
to have been our main food supply for the next month on the trail.

There was no Factor at the Hudson Bay Post, for he was south at the Lac La Ronge Post at the time, and purchase of stores was made through his halfbreed wife, who spoke Cree well, but only a very little broken English, so that conversation was carried on with difficulty; for at this time I knew but a few words of Cree. There was only one more Hudson Bay Post between Stanley and my ultimate objective in the north-that of Fort Du Brochet at the far end of Reindeer Lake-so here at Stanley I replenished my stores to the extent of 150 lbs. from the standard variety common to all fur-trading posts. Selecting a limited quantity of almost every available edible article in the store, my purchases were :-Two $24 \mathrm{lb}$. sacks of flour, 25 lbs. "Hardtack" ship biscuits, 5 lbs. rice, 5 lbs. beans, 15 lbs. bacon, 8 lbs. salt pork, 5 lbs. sugar, three cans of syrup, 3 lbs. evaporated apples, 2 lbs. baking powder, $2 \frac{1}{2} \mathrm{lb}$. bag of fine salt, 2 cakes of soap, $\frac{1}{2} \mathrm{lb}$. cut tobacco, $\frac{1}{2} \mathrm{lb}$. black plug tobacco, three hundied 12-bore cartridges, one spoon troll for pike, one tump line (for roping and carrying loads over portage), two yards mosquito net, and one pair of socks.

The Provincial Government had arranged with the Hudson Bay Company, previous to my departure, to take care of and transport whatever specimens I collected on the expedition, so at their trading post I packed 57 skins and 47 eggs for shipment, those I had taken since passing Ile à la Crosse post. 
Stanley Mission Post is at an abrupt angle of the Churchill River, for the down-trending waters flow unseen through Rock Lake in an almost duesouth direction to narrow, then expand to broad river width, at Stanley, and swing again into its natural easterly course. The scattered settlement is on both banks of the river, north-west and south-east; however, the greater number of mudplastered cabins and canvas-covered teepees (wigwams), and the Protestant church and mission, are on the north-west shore. There is one island in the bay opposite the north-west shore. Wooded hills are behind the settlement, while on the low ground there is clay soil in which good potatoes are grown. I noticed Dandelions growing here, and surmised they had been brought up at some time in potatoes or other foreign seed. Stanley Mission Post is the largest settlement north of the Churchill River. It contains about two hundred inhabitants, men, women, and children; and about twice that number of dogs. Very few of the natives are pure Indians, nearly all being a variety of castes of halfbreed. All speak Cree. The Post, owing to its geographical position, might almost be said to be on the outer fringe of the Frontier, for it is, though distantly, in touch with the large northern town of Prince Albert through the route which lies directly south, some two hundred miles in length, via La Ronge Lake and Montreal River : therefore the race of Indians is affected by contact with civilisation, as almost all Indians are to-day, except in the most remote and furthest-north territories which they inhabit-afiected in purity, 
in physique, in reserve, and the quiet grace of race which indubitably marks, and marked, the full-blooded Indian.

Of our two great religions the Catholic faith appears to be the stronger pioneer on the outskirts of civilisation in North-west Canada, and beyond, for at a great many surprisingly remote stations of the Hudson Bay Company it has established missions where priests work faithfully alone among the few somewhat pagan inhabitants that constitute / their /charge. Therefore one comes to take Catholic missions as a matter of course on the north trails, but here, at Stanley, was a less common institution-a long-established Protestant mission which at the time of its beginning must have been a great pioneering venture on the part of the mission, and missionary, which undertook it, and even now could give to a man exiled from his kind, and the customs of his kind, but little comfort and reward excepting a measure of satisfaction to earnest conscience and devout determination. The highestup habitation on the hillside on the north-west shore is the mission house, while the church, dominant and outstanding in this place of tiny dwellings, is erected on the east margin of the settlement, near to the shore. Inhabitants of Stanley say the church was built sixty-five years ago, and as it is the most pretentious erection north of the Churchill, and has been so for many years, I will endeavour to describe it. The architecture, if it could be so called, was crude, almost barn-like; such as could be described was Gothic in design. The church was constructed with 
timber above the foundations, which were of rough stone imbedded in and plastered with clay. The main aspect was that which most churches bear in greater or less proportions-a tower rising high over the entrance; a nave forming the main body of the church, lighted from clerestory windows; and narrow side-aisles behind columns, and below roofs intaking to the upper walls. There was a small vestry in the rear, but no transept, and so the pulpit stood on the right of the congregation at the head of the nave. There were seats in the nave, and bare forms against the walls in the side-aisles, while in a space in the nave at the rear stood a simple, antique-looking font, which I thought the most beautiful thing in that strange place of worship. The whole was impressive, since it was obviously the outcome of the rude labours of necessity of men who wished beyond all else to advance the faith of God to the outermost corners of the world. A large wood-burning stove stood at either end of the nave, for heating purposes in winter, and from those stoves unconcealed galvanised smoke-funnels ran overhead to find an exit finally in the roof; the whole being one of those harsh, incongruous necessities that one finds in out-of-the-way places and which are most disturbing to one's sense of good taste. The church, well packed, could seat two hundred people. All hymn-books were printed in the Cree language. The whole interior of the church was kept in some degree of preservation with paint, paint that, alas! in effeet was almost vivid rather than gravely peaceful; again, no doubt, a 
circumstance occasioned by necessity-lack of colours to select from, and the impossibility of having an accurate blend sent in to that remote station by any but a particularly enthusiastic craftsman. The walls, and ceilings between the rafters, were painted pale blue; the column white; and, for the rest, all woodwork was painted dark reddish-brown-the cornice, the column caps, the window-frames, the roof-rafters, and the seating-while the window openings contained leaded glass divided into small oblong panes of red, 'yellow, blue, green, purple and white in glaring contrasts. I came again outside, and was almost glad of the grave greyness and ill repair of the exterior, which appeared to be in the last stage of decay; moss growing on the weather-beaten, paintless grey boarding, and many places broken and growing to an open wound.

Leaving the church, the door was closed and secured with a piece of string tied to a nail.

June 24.--It was daybreak at 2 a.m. and the rain was easing outside the tent. By 4 a.m. we were hauling up tent-pegs and preparing to leave Stanley. There was a light wind from the north, but it was dull and cold-more like Fall weather than that of June. Small openings of clear sky showed scantily through dreary, dullgrey clouds-disclosures more blue than any of a common summer's day, and it is probably on account of the strangely cold atmosphere that there is such brilliancy to-day.

Proceeding on our way down the Churchill River, we soon came to Grave Rapids, below 
Stanley Mission, and nearly upset the canoe in running them. We were running the rapid on the left of the swells that surged down the middle, when, in a flash, we were too far into them, and shipped a canoe-load of water before we righted on our course and fied on swiftly to the foot of the rushing water. Then, lurching heavily, we paddled ashore and emptied the canoe, finding as before that the canvas cover had saved most of our provisions and kit from the water.

Thereafter, after some delay in finding the inlet, we came on through Rapid River Lake.

About 2 p.m. we portaged at the rapid above Drinking Lake and again had lake expanse before us and an unobstructed stretch of water through which we made good progress. The shores of Rapid River Lake and Drinking Lake were similar to those previously passed, except that neither were very confusing in outline.

At $4.30 \mathrm{p} . \mathrm{m}$. we reached the foot of Drinking Lake and made a portage at the entrance to the narrows above Key Lake, where an island separates the river into two channels : a large main channel and a small channel. Down on the rapid water of the latter we ran in the canoe, thus evading the fall which obstructed passage at the foot of the other channel. Here we camped for the night within hearing of the pleasant sound of tumbling, hurrying water, well satisfied with our long day, for we had covered about twenty miles as the crow flies and overcome three rapids. A number of birds were noted, but none collected, since they were either commonplace, or of species I had already collected, 


\section{ON THE GREAT CHURCHILL RIVER}

June 25.-On the water about 6 a.m. and proceeding onward through Key Lake.

About 11.30 a.m. we reached the bottom of the lake, where we portaged overland at Key Falls.

Below the falls, going quietly downstream, we came on a very large brown bear. The bear, when first seen, was wading belly-deep in the water on the outside of some reeds on the north shore on the prowl for fish-suckers or pike, which such animals capture by striking at in the water in lightning scrap fashion. Providence or sense of danger stirred in the brute while we watched, for it waded leisurely ashore and disappeared into the bush before we had even planned how to get near enough for shooting. The animal gave no sign of having seen us or scented us, and so we were induced to paddle down on to the south shore of the river, and go into hiding opposite where it had been hunting on the chance of its returning. There we lay up for two hours, but our patience was unavailing, and disappointed we resumed our journey at the end of that time.

In the late afternoon we made a portage at Grand Rapids and camped for the night at the lower end. The portage at this rapid was a long one, nearly half a mile in length.

Again and again I am prompted to exclaim in admiration of the vastness of the Churchill River. After twenty-four days on the great waterway, her lakes and rapids have not lost one whit of their impressive strength and grandeur; unbridled force running wild; powerful water-power worth many a man's kingdom if only it were within the boundary of civilisation. In such a 
trend of thought one is apt to try to look into the far-distant future and wonder what changes another century will bring and to what industries mankind will turn when they assail this virgin country. Lumbering, though the timber is small in comparison to the great trees in British Columbia and elsewhere, will probably be the first industry to be taken up, while rich minerals may be found, and good agricultural land; though on the river bank I saw no promise of the latter, much of the ground surface of the forest being bare rock and boulder where sand takes the place of soil. But no living white man yet knows what the interior of the vast northern territory holds; inland there may be great tracts of soil suitable for agriculture. Only the waterways, where summer canoeing is possible, have been roughly surveyed. Beyond them the maps remain a great blank space.

During the day I collected some specimens of birds and found a number of nests. In the evening I caught a pike weighing $3 \frac{1}{2} \mathrm{lbs}$., which I was astonished to find had an adult Cedar Waxwing in its stomach. Dissolution had not set in, the bird was intact, and easily identified. Waxwings prey much on insects, and I fancy this bird had dipped to the water surface in pursuit of a beetle or shadfly, and the ravenous pike had on the instant risen and seized it.

At dusk I took my rifle and went quietly back on the portage path to the top Grand Rapid in the hope of seeing bear, but had no luck, though bears at this season of the year frequent such places if they are in the neighbourhood to prey 
on the shoals of black and red suckers, many of which are easily cornered and captured in shallow channels and pools in the angular, rocky steps of a fall.

June 26.--To-day we travelled Island Lake, the last lake expansion between us and the mouth of the Reindeer River, where our journey on the Churchill would end. Island Lake held beautiful scenery. After leaving the east end of the lake, which was something like many of the others in rough shores of bewildering outline, there lay before us a wide expanse of water, the clean-cut shores of which had straight distances of green grass and coniferous tree-trunks rising perpendicularly from the earth, their bases unscreened by willows. Nearing the north-west end of the lake there were a few pretty islands where bright grass blended with the darker green of shapely poplar trees. The water of the lake was clear, so clear that it sometimes permitted a view of the clean, stony bottom through a good depth of water.

In the afternoon, after spending some time searching through one or two of the islands, we reached the end of Island Lake and there located Frog Portage on the south shore opposite an island, where the river takes a sharp turn into the north-east. Frog Portage is an overland link into Lake of the Woods, which is the north end of the Sturgeonweir River route, that runs 150 miles south to Cumberland House and thence forty-five miles east to The Pas in northern Manitoba, where, for the present, terminates the railway service on the Canadian Northern 
branch now under construction to Hudson Bay. I made particular note of the position of Frog Portage, which was difficult to discern until you are almost upon it-as, indeed, are all Indian trails-and I cut a large blaze on a solitary tree which stood on a bare point on the east shore after resuming our journey, so that I would be warned when I approached it on my return and might be sure of finding it, for it was by the above route that $I$ intended to return to civilisation at some distant date in the future.

There were some Crees camped at Frog Portage : four teepees containing one deaf old man and a number of women and children. With the exception of the old man the male inhabitants were away "freighting" stores north from Pelican Narrows for the Hudson Bay Company. I photographed the gipsy-like dwellings, after I had overcome the old man with a gift of tobacco, to the seeming consternation of the female inmates, who in their acute shyness reminded me somewhat of alarmed sheep.

Leaving Frog Portage behind we continued onward in a more north-east direction than hitherto, until approaching darkness bid us camp.

To-day I saw a Mink swimming rapidly ashore with prey in its mouth. With my shot-gun I fired near to the animal as it landed, and it dropped what it carried, which proved to be an eel fifteen inches long, showing by deep-sunk teeth-marks that the strong, squirming thing had been held in vice-like grip across the head to subdue it and prevent its escaping. To-day, too, I again saw a Porcupine swimming in the water. 
Previously, on June 11, I had noted a similar occurrence.

June 27.-This was our last day on the Churchill River, for about 2 p.m., after portaging at Kettle Falls, we came to the mouth of Reindeer River and turned north up that broad stream of crystal-clear water that cut a well-defined line where it joined the more brownish water of the Churchill.

Stiff paddling henceforth lay ahead : against current we must now journey onward; no longer was our course downstream.

Somewhat reluctantly we bid good-bye to the stream whose name and character had grown familiar and given us pleasure, and thereafter faced the dim trail into the distant North. Always, on such travelling as this, the familiar scene and the knowledge and experience you collect go back to the Past, while ahead, round each bend, and island, and point in your course, lies the alluring, unravelled unknown of the Future. So like our lives ! - the plan unfinished, the map of our course to be drawn as each day leads onward. Unseeing what is in front of us, yet in faith picturing scenes as we imagine them to be, and as we would like best to find them.

But so far as the Churchill River was concerned our travels there were ended, at least for the present. We had voyaged by lake and stream for forty-seven days, twenty-seven of which had been spent on the broad, beautiful waterway which I have endeavoured to describe.

Below I give a summary of the Churchill 
River from Lake Ile à la Crosse to Reindeer River :

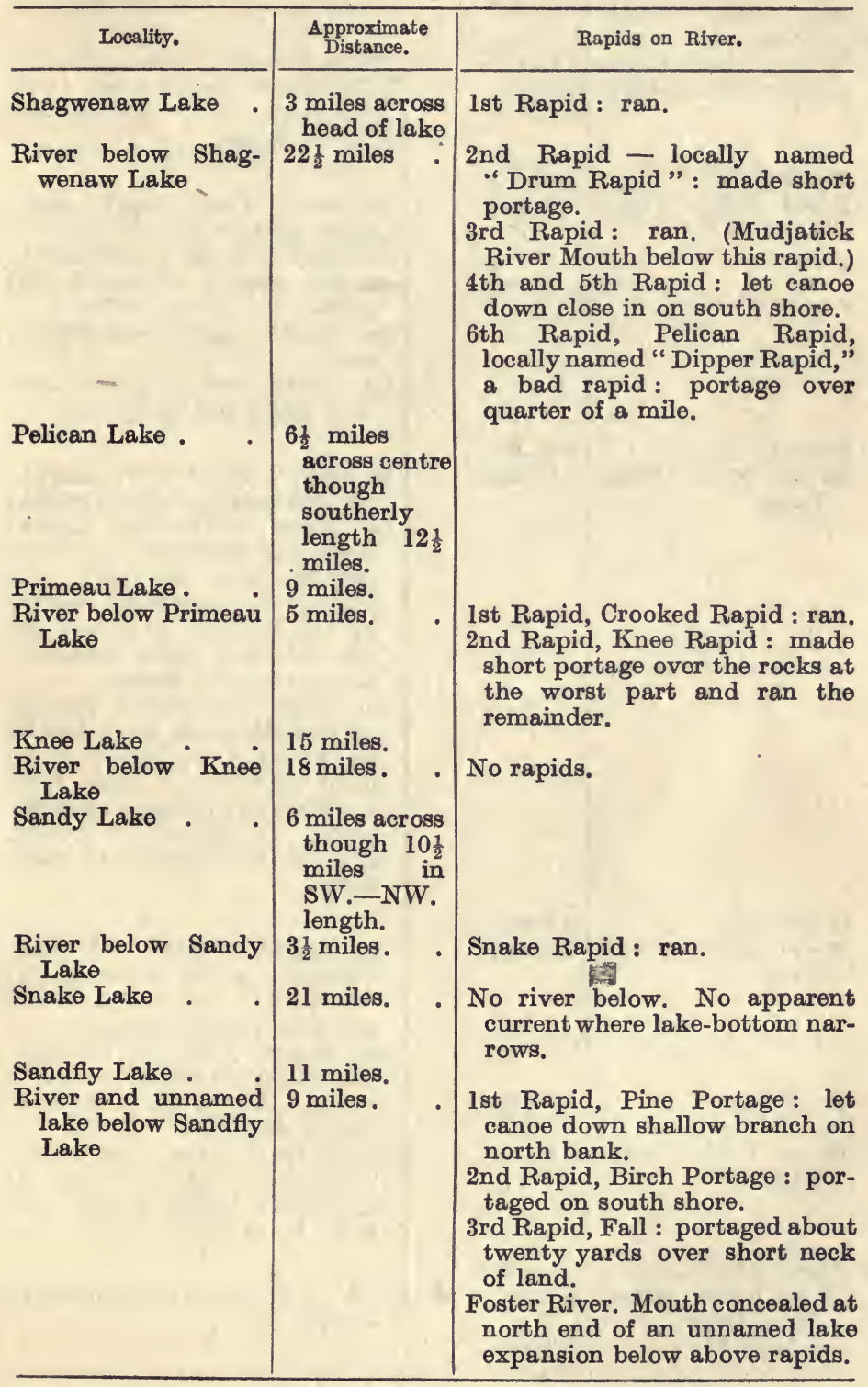




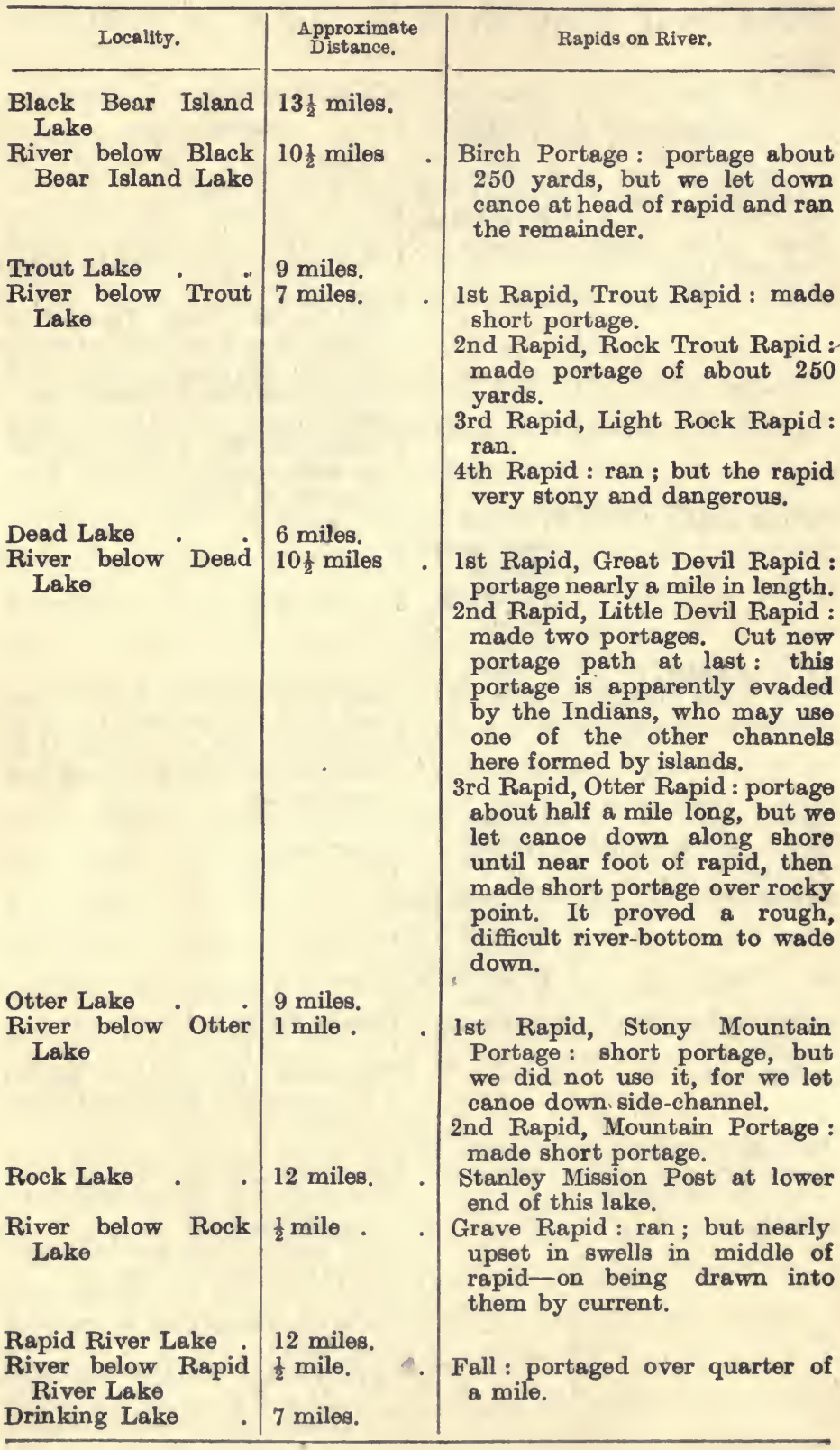




\begin{tabular}{|c|c|c|}
\hline Locality. & $\begin{array}{l}\text { Approximate } \\
\text { Distance. }\end{array}$ & Rapids on River. \\
\hline $\begin{array}{l}\text { River below Drink- } \\
\text { ing Lake }\end{array}$ & 2 miles & $\begin{array}{l}\text { Island Portage : made portage } \\
\text { at entrance of narrows, then } \\
\text { ran down in side-channel, thus } \\
\text { evading falls at foot of main } \\
\text { channel. }\end{array}$ \\
\hline Key Lake . . & $9 \frac{1}{2}$ miles. & \\
\hline $\begin{array}{l}\text { River below Key } \\
\text { Lake }\end{array}$ & $2 \frac{1}{2}$ miles & $\begin{array}{l}\text { Key Falls : made short portage. } \\
\text { Grand Rapids : made portage } \\
\text { of about half a mile. }\end{array}$ \\
\hline $\begin{array}{l}\text { Island Lake or Trade } \\
\text { Lake }\end{array}$ & & \\
\hline $\begin{array}{l}\text { River below Island } \\
\text { Lake to mouth of } \\
\text { Reindeer River }\end{array}$ & 26 miles . & $\begin{array}{l}\text { Kettle Falls : made short por- } \\
\text { tage on west bank. }\end{array}$ \\
\hline
\end{tabular}




\section{CHAPTER V}

REINDEER LAKE AND FORT DU BROCHET

Reindeer Lake! Fort Du Brochet! Names remote on the map of Canada, names situated in that Far Northern hinderland where so few have come into being that each denominates a kingdom of virgin country which lies, unknown to our race, on all sides of the point that has been discovered. To me such names are big with possibilities, big with the attraction of things mysterious, big because they shelter a country that is waiting the races of the future. Yet to you, no doubt they are mere names of Lake and Post to be glanced over and forgotten, and given back to the gigantic soundless wastes of semi-Arctic Canada. Because they are hidden away in far-off distance they hold what fame they have in the still unravelled clouds, and the secretive silence, of the ever-passing years.

Reindeer Lake is between longitudes $102^{\circ}$ and $103^{\circ}$ and extends north to latitude $58^{\circ}$. It is a vast sheet of water which stretches 140 miles north and south, and forty miles across where its width is greatest. It is in a country of rock, and muskeg and low-lying hills which are filled with silence and unseen creatures.

The lake contains countless islands (some thousands) which are wooded, as are the land 
shores, with the strong character of dark-peaked Spruce and Scrub Pine, and a few Tamarac and Birch. The island shores, which are bordered with Willows at the fringes of the forest, are rugged and grey with rock and boulders, brightly relieved for occasional stretches with long low bays and points of spotless, warm-toned sand. Distant stretches of water open up between the islands, low smoke-blue hills show faintly in the distance, miniature traceries of dark trees rise, like masted ship, out of reflecting shadows on the far lake surface where hidden islands lie, and right out, as if at the end of the world, the waters die away into the clouds where no land is in sight. It is a wonderful lake of hidden distances which appear and disappear in all directions behind the foreland, as onward you travel through a truly bewitching fairyland. And over the clear blue waters of the lake, reaching far into the great distances, reaching even beyond into unseen but imaginable places, there reigns impressively the weight and solemnity of an. unseen Spirit. It is the Spirit of the North-silent grandeur, and vastness, and untouched purity of a Virgin Land lending awe and greatness to Creation. It is the dominance of that Spirit which. makes man feel, when in the great grave presence of it, how impotent, how insignificant a part of the Universe he is, and how humble he should be.

There are two Trading Posts on Reindeer Lake : one, a winter post, is on Big Island at the south end at the head of Reindeer River; the other, Fort Du Brochet, the chief Post of the territory, is on the north mainland near the mouth of the 
Cochrane River. The two Posts are, depending on wind, five to six days' canoe journey apart, while the York Boat of the Hudson Bay Company - a cumbersome, wide-beamed sailing craft of some forty-foot keel-with following wind (and the Indian crew always wait for such a wind when about to make the voyage), and travelling day and night, can accomplish the distance in two days.

It was in mid-July that Joe and I in our solitary canoe approached the north end of Reindeer, Lake and sought the inlet which would hold some sign of habitation.

Night was creeping down over the earth, and the shores were darkening to blackness when our journey on the lake drew to a close and we neared the Post of Fort Du Brochet. The gladness of a summer's day was folding its spirit in repose, and the inflexions of a score of tiny nature sounds were fading away into the darkness, though still the strained ear caught the laughing trickle of water against the canoe and the lowspeaking lap of the gentle waves as they came and went with the lazy northern breeze. Our approach was unheralded, and the lone canoe stole softly inshore, where cabins stood solemnly silhouetted against the wistful sky. Dim figures moved on shore to the left, and low voices, in native conversation, rose-then died away. Stars peeped out, and the Northern Lights grew clear in the overhead sky. A rising fish splashed-and another. . . Then silence reigned.

The canoe was run in on the sand close by the shadowy landing, and my companion and I stepped ashore to pick our way up the rough path to the 


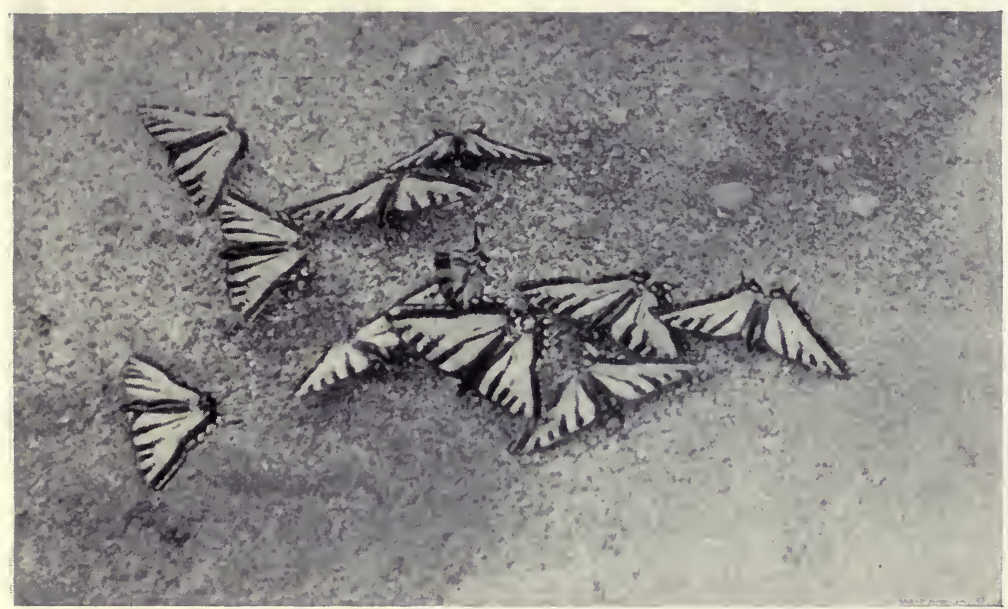

BUTTERFLIES ON MOIST SHORE SAND OF REINDEER LaKe.

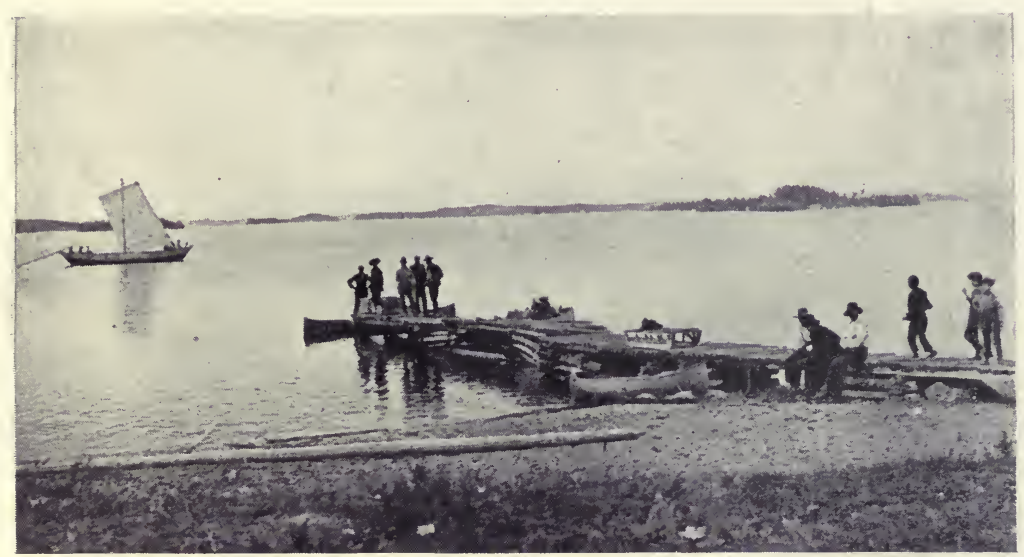

THE LANDING AT FORT DU BROCHET. 

Fort. Night settled down to death-like silence. The Spirit of the North was in the air, and in the solitude of the lonely Post.

After rounding an island promontory Fort $\mathrm{Du}$ Brochet is approached, where its scanty settlement of miniature dwellings stands grave and grey in one of those hidden inlet bays so common to all waterways of the rugged North. The small gathering of teepees and cabins shows suddenly and at close range before the vision of the voyageur, and he welcomes them, after his long, hard journey through unpeopled country, as an unexpected find. He exclaims with pleasure at the sight of habitations, and excitedly anticipates the joy of conversation with the white or halfbreed trader at the Fort. It is the way of men on the outer trails to be delighted with such rare meetings with mankind, for as they gain the freedom of the wilderness the mind looks ever back to its harvest of memories of companionship, and looking back grows ever hungrier for the voices of their kind. Those primitive shelters, artless and somewhat uncompromising in line and colour, are therefore as welcome to the traveller as at other times might be the comfortable bungalow of a civilised home. Indeed, it is possible they are more welcome, for in the Silent Places men learn a greater appreciation than in a world of ease.

The small, log-hewn, square-built cabins are weather-beaten and grey like time-worn boulders on the wayside, and stand solitary as sentinels on a bare, treeless, grass-grown knoll. The Fort -the buildings of the Hudson Bay Company, 
comprising a house, a trading store, and an assortment of outhouses-stands dominant on the highest ground on the extreme east of the knoll. To the west, strange to say, is a tiny Catholic mission and church ; the latter cross-planned, as is the Roman custom, notwithstanding its insignificant size and crude workmanship. At some little distance from the mission is the Trading Store of the "French Company" (Revillion Brothers), rival traders to the Hudson Bay Company, who here established a footing some ten years ago. There are six cabins in the settlement occupied by part-blood or full-blood Indians, who are at intervals in summer and winter employed in the transport of furs and stores for the trading companies. White fungus-like tents, in awkward discord with natural colours, are pitched here and there along-shore. They are the temporary shelters of the ever wandering Chipewyans, for alas! the days of the mahoganycoloured, smoke-soiled deer-skin (caribou or moose-skin) teepees have almost gone, and their peaked pyramid forms range no more in native beauty along the shore-front.

There is little stir of life around the cabins during the long summer's day, for the men are commonly away fishing or hunting or "freighting " for the Company, and the few squaws, with their half-wild children about them, keep chiefly to their dwellings. Occasionally the dogs of the Post, which form the greater part of the population, give voice to vicious quarrel or howls of deep-rooted melancholy; but, as a rule, they are to be seen curled up in slumber here, there, and 
everywhere, indifferent alike to the peace or desolation of the quiet scene.

Such is the aspect of Fort Du Brochet, the furthest inland post in the region and one of the hardest to reach from the far-distant frontier. One may call it a rude settlement in a rude land of water and cloud and wilderness : yet it had its native life of quaintness and simplicity; and, above all, its summer days, and its sunsets, and its Northern Lights of superb, wild, natural beauty.

The clear blue water of Reindeer Lake is teeming with fish, and it is almost as wonderful on that account as it is for its rare northern beauty. And those fish abound in water that is exceptionally fine, and which, no doubt, gives to them wonderful growth and well-being. An extract from the Canadian Geological Survey Report on the country between Lake Athabasca and Churchill River, 1896, p. 99 D, states :

"A chemical examination of the waters from Reindeer Lake and Churchill River was made by Dr. F. D. Adams in the Laboratory of the Survey in 1882. In summing up the general results, Dr. Adams says : 'Of the foregoing waters that from Reindeer Lake is remarkable for the small amount of dissolved solid matter which it contains ; in this regard it would take rank with the waters of Bala Lake, Merionethshire, Wales, and Loch Katrine, Perthshire, Scotland. . . ."

There are, in Reindeer Lake, as far as is known to me, eight different species of fish, most of which are to be found in many of the waterways of the North, particularly where rivers flow, or have 


\section{REINDEER LAKE AND FORT DU BROCHET}

connections to lakes. Many small land-locked inland lakes apparently contain no fish, or very few, and those usually pike.

The fish contained in Reindeer Lake are, if we exclude the small fry of which I had not sufficient time or opportunity to take account, Whitefish, Lake Trout, Back's Grayling, or Arctic Grayling (?) Pike, Pickerel, Red Sucker, Black Sucker, and lastly a small herring-like fish, indigenous apparently to the south end of the lake, which, after reference to specimens in the Museum at Ottawa, I believe to be the Alaska Herring, or Mooneye Cisco.

The Whitefish is the great food fish, both for the natives of Reindeer Lake and their sled-dogs. The flesh is white and delicate, and delicious to eat; and one never tires of it even when it is made a constant diet. They are caught only in gill-nets, and weigh on an average between two and three pounds. The smallest fish I saw taken weighed one pound, and the largest six pounds. In shape the whitefish is narrow-backed, with a full, curved outline and deep-girthed sides which are covered with silvery coarse scales; the head is small, and tapers sharply to the fine-lipped, toothless mouth. The lower sides and belly are silvery white, which is the striking colour of the fish, for they look like bars of silver when freshly caught; the upper sides glint with pale bluish-purple, or reddish-purple in some instances, and darken into the brown over back, while the scale outlines there show black. The dorsal fin is of ordinary size; not large, and brightly coloured like the grayling, which it resembles somewhat in shape and size. 
The Lake Trout is almost of equal food value to the Whitefish, but it is never caught in great numbers by the Indians in their set nets. The flesh of this fish is deep yellow, and firm and fullflavoured; but one tires of it quickly as a regular diet, probably on account of its richness in fat or oil. In shape those trout are full and lengthily well proportioned; in colour the fine scales are silvery white on the lower body, and whitespotted sage-green brownish above, while there is a thin, dark, well-defined line along the centre of the sides. They are powerful fish, usually weighing between three and a half pounds and eight pounds, though they are occasionally caught of much greater size. I secured one weighing nineteen pounds, and preserved the skin, which is now mounted in the Saskatchewan Museum. One is recorded weighing twenty-five pounds, caught near the mouth of Stone River. ${ }^{1}$ Those trout can be easily caught on a rod by trolling a minnow or spoon, but fly was tried on a few occasions without success, though fish were seen breaking the surface of the water in all directions on suitable evenings.

I had no occasion to catch more trout than the day's needs required, and on Reindeer Lake, particularly at the south end, half an hour's trolling was often sufficient to take a five to ten pound basket; when the rod would then be put away. Fishing for food in this way during the six days it took to travel from the south to the north end of Reindeer Lake, my catch totalled

1 Report on the country between Lake Athabasca and Churchill River, 1896, p. 14 D. 
thirteen trout, weighing fifty-two pounds. I have often wondered what a whole day's catch would amount to in weight in those unfished waters, and almost regret I had not occasion to make the test.

Back's Grayling, or Arctic Grayling (?) is only on very rare occasions caught in nets by the natives. They probably do not live long periods in Reindeer Lake, unless that when doing so they keep to the deep waters and avoid detection. I have caught them below Reindeer Lake on the Reindeer River, and above Reindeer Lake on the Cochrane River. They are much given to frequenting the swift waters of river rapids, and it is there that $I$ invariably found them. They were caught only on a small phantom minnow, which was the only lure I could induce them to rise to, and weighed between one pound and a half and three pounds. They were exceedingly game and fought splendidly in the swift current. From an angling point of view they afforded more excitement and fun than did the Lake Trout. I greatly enjoyed fishing for them, and also the scramble over the rocks to reach their favourite "lies " in surroundings where the river roared and tossed in companionable tumult.

In shape the Grayling resembles the Whitefish, but the flesh is not so firm, and white, and palatable, though quite fair eating. In colour the upper sides are silvery brown, with glints of pale blue, and also with slight yellow and red tints, while there are a few widely spaced prominent black spots on the fore-shoulder; the back 
is darker than the sides, and therefrom arises a very large dorsal fin, almost a third of the length of the fish, which is brilliantly spotted and streaked with many lights of deep purple and greenish blue; the belly is blackish when the fish is first taken from the water, but later it pales to white. It is, altogether, a brilliant rainbow-tinted fish when seen swimming in the clear water, but quickly loses much of those glints of colour when killed.

The Pike.-This fish, commonly called Jackfish in Canada, is that long-snouted, somewhat repulsive fish that everyone knows; and it needs not description. Its flesh is quite edible in northern waters, but nevertheless it is never used for food by the Indians when Whitefish and Trout can be got. I caught many of those fish on spoon or minnow, and took one on the rod weighing eighteen pounds.

The Pickerel, an American species of Pike, is very similar to the above, and was almost equally common, and taken with the same lures.

The Red Sucker is very plentiful in Reindeer Lake, and in the river flowing into it, and is often caught in nets along with the Whitefish. It is used for dog-food, but only seldom for human food, although the heads cut off and boiled are often eaten by the Indians, who consider the eyes a delicacy. The flesh is white, but somewhat soft, and, if used for native food at all, is dried or smoked previous to consumption. In shape they are a broad-backed, round-barrelled fish of equal depth and width, while below the blunt-pointed snout is the puckered, toothless, circular mouth from which they derive their 
name. They weigh, as a rule, between two pounds and four pounds. In colour the fish is white underneath, with the under-fins tinted with shades of yellow and reddish chrome; the back and upper sides are medium dark shades of blackish-brown with a clear pinkish tint overlying the ground colour on the full length of the middle sides; the gills are yellowish.

In summer these fish are often seen in great shoals in the clear shallow waters of rapids, and their colours then show beneath the surface with oriental brilliancy.

The Black Sucker is very similar, but lacks the bright colouring of the Red variety. Both are fish imperturbable by any kind of lure, failing the possession of nets they may be speared in shallow water.

The Alaska Herring or Mooneye Cisco is probably the strange little fish which I saw taken for food purposes at the south end of Reindeer Lake. None were caught at Fort $\mathrm{Du}$ Brochet at the north end of the same lake, and the Indians declare they are known only at the first-named locality, which appears very strange. I saw many of those fish when passing on my way north, but omitted to secure specimens. And unfortunately when I returned in winter the lake was frozen, and none were procurable, though I tried.

I am unable therefore to positively establish the identity of this species, but certainly record the location so that at least the presence of this small herring-like fish, which is apparently peculiar to one particular section of water, may be 
noted and investigated later by others if not by myself.

Reindeer Lake is undoubtedly very abundantly stocked with fish, and one is prone to wonder if, in time, it will come to be exploited by the white race on account of their food value.

But meantime its vast expanse lies undisturbed; virgin - for one can almost discount the piscatorial activities of the handful of Indians that now live on her shores, for those are the activities of but a limited number of individuals who can make no visible impression on this inland sea. . . .

And so, of the future of Reindeer Lake one dreams, or is prone to dream, when camped by her shores when the sun is lowering in the goldrippled, peaceful 'West, and the air vibrant with the churring of nighthawks. . . And, as you muse, and night creeps in, further sounds of the wild awake and catch your acutely tuned ears, as does even the minute rustle of a mouse in the grass in the breathless intervals of overawing silence.... And at last, as if aware you had been waiting for it, from the shadow-filled swamp near-by arises the elf-song of the white-throated sparrow in mystic sweetness. . . . Then are you glad to cease your ponderings; glad that Time has not changed this wonderland: and that yours is the good fortune to camp on Indian hunting-ground, in the Indians' deep-shadowed land. 


\section{CHAPTER VI}

\section{THE BARREN-GROUND CARIBOU}

At the south end of Reindeer Lake, soon after striking north from the great Churchill River, one is vividly made aware, even in summer, that the land of vast Caribou herds has been reached. There at the Indian camp at the outlet to Reindeer River you will find strewn about the small Indian cabins, in untidy disorder, remains of many Caribou-bleached hair, hoofs, and white, weather-washed knuckle-bones-which even wolfish sled-dogs have given up chewing at in distaste at their absolute poverty. Afterwards, as you pilot your way northwards, through the great lake of forested islands, you will be astonished, wherever you land, at the number of Caribou paths that lie before you-clear-cut paths, worn down by the hoofs of countless animals, following, Indian-file, one after the other over the cranberry, moss-grown, sand surface of the woods-paths not grown over; unchanged since the time of the last migration except that they bear no fresh hoof imprint. Those paths are traced in many directions, but perhaps the greater number, and those most deeply worn, are those which run north and south.

You have reached the great winter-haunt of the Barren-ground Caribou (Rangifer arcticus). 
Since the beginning of time, as far as men know, they have always come here-Reindeer Lake! Assuredly not for nothing had it been thus named.

In that particular territory the southern boundary of Caribou migration may be said to be the Churchill River, though animals have been killed on rare occasions as far south as Cumberland House on the Saskatchewan River. But the great area of Reindeer Lake, larger than a halfdozen English counties, is pre-eminently the favoured winter feeding-ground.

In October or November each year large herds of Caribou reach the north end of the lake, and apparently continue south chiefly on the eastern shores. Thereafter they scatter abroad for a period, and travel slowly from place to place, over frozen lake and snow-lain forest, while feeding on abundant white moss and marsh-grass, and a consideration of mud which they seem to relish.

In winter their method of feeding is to dig down to the ground-surface with their remarkably sharp forefeet, and then to work forward in the channel they have made in the snow, which is sometimes of a depth of three feet or more. When the depth of snow is very bad the Caribou prefer feeding in open muskeg valleys, between the more densely grown forests, where the wind gets at, and sweeps away, part of the covering, and the labour to reach the undergrowth is accordingly less.

Early in the year the does and yearling fawns again commence to move northward, while the bucks remain behind to follow later. They return not as they came, not chiefly on the eastern 
shores of the great lake, but scattered broadcast among the islands of the frozen lake, and on both mainland shores. The fact is that theirs is a leisurely return, since there is no weather change to urge them to haste-as is the case when the great massed droves hasten south-and so they travel easily, and in food-seeking, scattered herds. There is almost certainly a second reason for the leisurely return of the does and fawns, and that is the maternal instinct of the does, for many of them are with young that they will give birth to in early spring.

One can easily understand why those great herds of Caribou travel south in the Fall. The undergrowth on the Barren lands is plentiful, but there are no trees. When winter comes the wind, driving over the exposed white surface, packs the snow hard, and an icy crust forms through which it is difficult, sometimes impossible, to break for grazing. It is, as it always is by nature's arrangement of things, a question of existence, this insistent migration of those animals. As the thermometer drops in the Far North, and food and shelter become difficult to find, the animals will band together and grow restive, and pause from time to time to sniff the wind from the south with question on their countenance. And one day, with proud heads up and anxious eyes, they will commence their long travel through sheltering forests where snows are soft and food is plentiful beneath the yielding surface.

At Prince Albert, or any frontier town, you may on rare occasions run across a Cree or a 
Chipewyan Indian who has ventured out to the white man's country, to "the people who live behind rocks"-as he terms the white race that live in stone-built houses. If you question him closely, you may hear of the great Caribou migrations which pass his far-off wigwam at some nameless point in space and which provide him with meat stores for half the months in the year.

If he narrates vividly his story will be legendlike as the tales of Buffalo herds on the North-West prairies half a century ago or as the tales of the herds of Pronghorned Antelope-that, alas! have wasted away since civilisation came to the prairies, and the fences of the Canadian Pacific Railway held them hapless prisoners when they longed to answer the insistent call to the south, and to change which was essential to their existence.

In many ways I had heard of the migrations of the Barren-ground Caribou, each new tale whetting my desire to witness them. The Buffalo had gone, the Antelope were almost gone; mankind would never again witness those great animal herds in their wild state. There remainedbeyond the pale of white man-the last of the roving big-game race in Canada; the Barrenground Caribou

I had read at one time some records of Caribou in a work entitled Through the Mackenzie Basin, which contained "Notes on Mammals," by R. Macfarlane, and I had written them down, though little knowing that I would ever come to think of them again. Those records were :"Caribou observed passing in the neighbour- 
hood of Lac du Brochet (north end Reindeer Lake). Fall migration witnessed in October, November, or December. Spring migration in April, May. Caribou seen each year from 1874 till 1884: none seen from 1885 until the autumn of 1889."

Those notes contained for me one main ideathat Lac du Brochet was a particular winter haunt of the Caribou. That thought caught hold and took root.

Hence you have found me entering the Land of the Caribou-hence was $I$ in the middle of August 1914 (beyond the reach of knowing of war, which I did not learn had broken out until October) approaching the height of land that occurs in latitude $59^{\circ}$ and longitude $102^{\circ}, 800$ miles, by the course I had travelled, from my starting-point east of Prince Albert.

Passing Fort du Brochet, before entering the Cochrane River, I had been told by Philip Merasty-an ancient Hudson Bay servant and crafty hunter, and a fine old halfbreed who, but for his name and elementary mission education, you would take for a full-blooded Indian-that during the past three years the Caribou had been arriving in their neighbourhood at an earlier date than formerly. It was in October and November that Caribou appeared in former years, he said, but they looked for them now in late August and September. Yet in his crude diary, which I found secreted in his cabin eaves some weeks later, I came on the illuminating information that his son Pierre had seen the first Caribou on frozen Reindeer Lake on October 21, 
1913. I would rather trust the diary record than the verbal one, and later experiences have borne this out.

However, for the moment, I had been encouraged by the Indians at the post to think that if I continued my canoe journey north I would have every chance of seeing Caribou at the point I now had reached.

I was in beautiful country. Beyond the bright gravel beach, and points of fine white sand, of lake and river shore, rose hills; gracefully rounded and sweeping in outline; massing large and bold and grand. Along the shores where moisture was plentiful were willows, and a few alders, and small green tamarac trees; at their roots, mosses, and much of that bushy ground-shrub known as Labrador Tea, the white bloom now dead, and rusty brown where unblown. Back from the shore were hills grown mostly with scattered, low-statured Northern Scrub Pine; the sand and gravel surfaces mosscovered, and the boulders green as the surroundings, with lichen.

From time to time I went ashore to search for signs of Caribou, climbing to bare, sandy, bouldered ridges in some cases, and viewing range after range of like hills, with marsh and lake pockets in the hollows in the foreground. . . . But never a sign of life in the distance-there at my feet game paths worn down by the feet of countless Caribou, antlers long cast aside, hair and bones where an animal had died, markings of hundreds of rabbits (varying hare), but not a single fresh footprint on the sand, except of fox and wolf. 
Animal life seemed dead; not even a rabbit moved, and I fear it must have been that minimum year of growth, that periodic time when the rabbit plague nearly exterminates the species in a region.

Day after day I waited-and watched.... Everything in the land had at first been beautiful, in my eyes-but, God! how the awful silence of its vast space grips you. Even now I felt it, even before the great covering of snow had muffled every corner of the earth, and land and water came to be bound in iron ice-grip.

At Fort Du Brochet I had been advised that I had not much time to spare before freeze-up set in, and that I would be well advised to return speedily. Later this turned out to be, for this particular year, a deceptive estimate; but, at the time, my waiting at the head of the Cochrane River seemed precarious if I was to get out to the post before ice formed on the lake, beach the canoe, and outfit for further travel by dogsled. Therefore, after two weeks of unrewarded watching for Caribou, I gave up, and turned the canoe-bow into the south for the first time for many months.

It was something over a hundred miles back down the Cochrane River to Du Brochet Post. The return journey began favourably, for the wind was behind, and wind and current sped the canoe merrily on its way; but on the following day, and thereafter, the weather broke down badly and rains and heavy head-winds delayed travelling. Indeed in mid-afternoon on one occasion the storm grew so fierce that I gave up struggling 


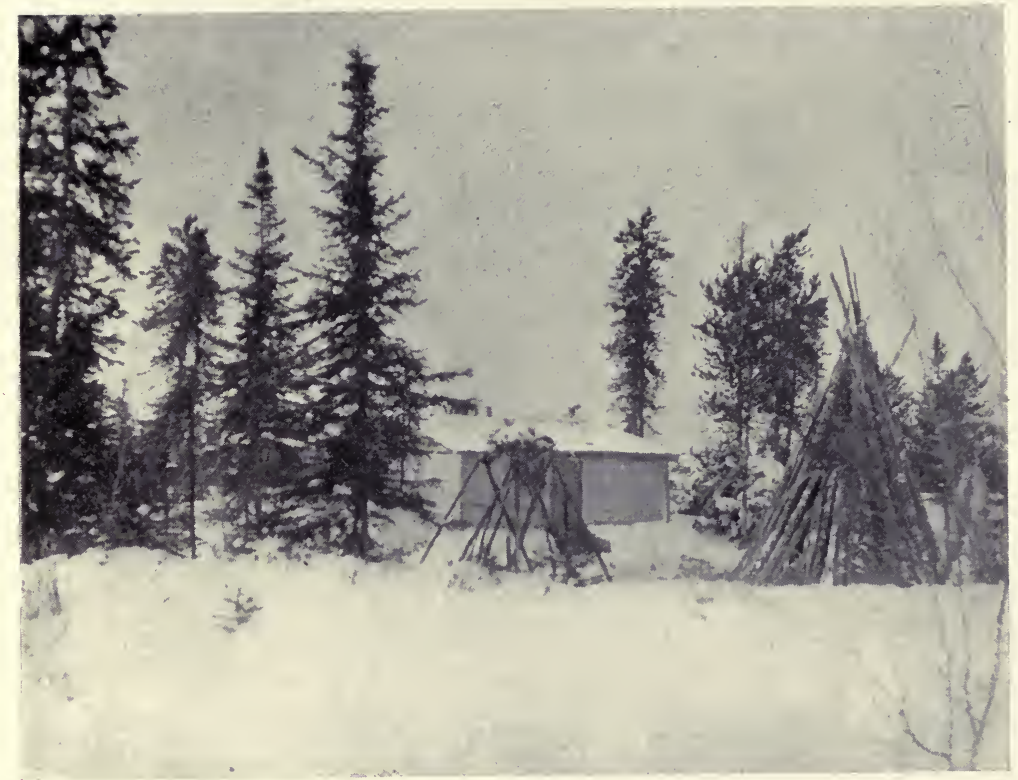

MY LOG CABIN.

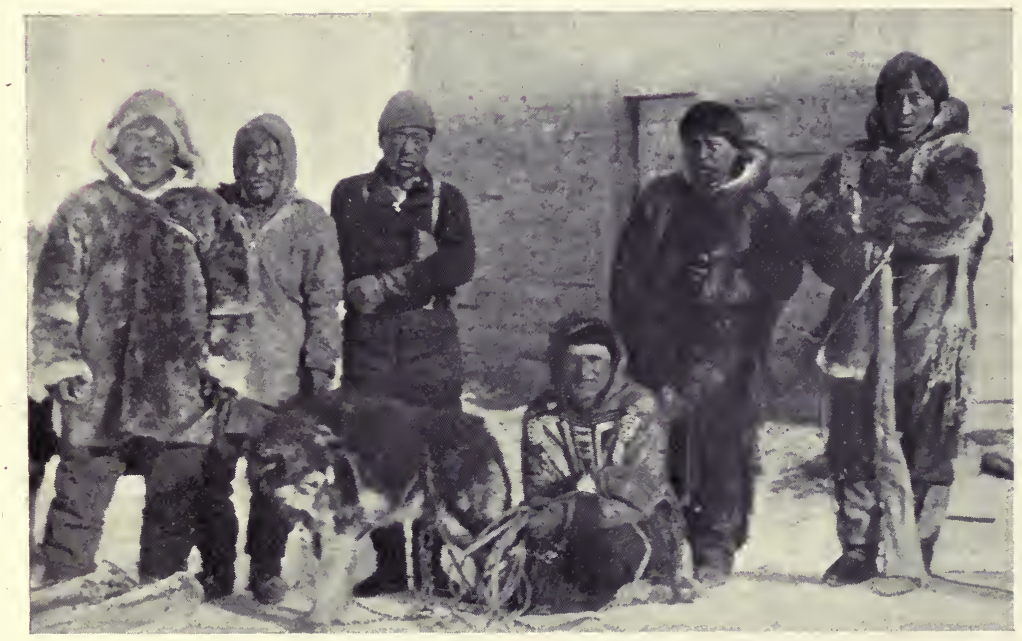

ESKIMOS. 

against it, and ran ashore and camped for the remainder of the day.

It transpired that broken stormy weather had set in for an extraordinarily long period, and on getting back to Reindeer Lake and Fort Du Brochet, I had a long time to wait for freeze-up during an extremely open Fall.

However, I had plenty to do while waiting, for, in addition to collecting a dog-team from the Indians at the Post, I set about building, on the margin of a small inland lake two miles north of $\mathrm{Du}$ Brochet, a log cabin which was to be "my home" and a winter base, a safe storage for museum specimens, and a-quiet outlook from which Caribou could be observed if in the neighbourhood.

To build a log cabin single-handed, and with only an axe, is a substantial undertaking, and, though I was hardened with months of " roughing it," I found it arduous work. Standing trees had to be felled, lobbed of their branches, and the heavy trunks carried from all directions to the site of the cabin : afterwards the labour of construction.

Working steadily from dawn till dusk, in three weeks my "home" was finished-moss packed between the horizontal tree-trunk cracks, and mud-plastered outside against penetrating wind and cold. If you have lived long months in the open in all weathers, you will know, when you reach habitation, the wonderful luxury and restfulness of living with a roof overhead, a place for one's belongings, and a completely sheltered cook-fire; and when it is driving rain out-doors, or blowing a wild old gale, or snowing pitilessly, 
or freezing bitterly steel-cold, you may know what it is to draw up to your glowing log-fire or lie snug in your deer-skin bag on your branchformed bed-if it be night-and feel altogether glad that you have not to rise up and go out and do battle with the elements.

Meantime, in the northern latitude the seasons were changing.

By mid-September the leaves of the birch trees had completely faded to tints of yellow and yellow chrome, and many had fallen. Summer birds had gone south, and their notes and cheepings were gone from the woods which held but the chatter of an odd red squirrel or the whistle of a friendly jay. Evening crept down earlier than hitherto. Night after night Northern Lights be-ribboned the sky as they fleeted across the zone from west to north-east ("The dance of the spirits," the Indians call this beautiful phenomenon); and always, now, when the wind veered to the north it had the bitter chill of snow in it.

On September 16 there were snow showers; on the 24th snow, and wind, and rain.

At the end of the month all leaves had fallen, and I walked in a land of mourning, half-thinking to step light-footed lest I disturbed the dead in a vast, deserted hall where even the evergreen spruce and pine frowned down on me darkly.

Those were days of brooding grey skies-days of frost and biting wind: days of repentance and thaw.

With October came freeze-up and snow, while Snow Buntings were about the wood-bottoms and lake-shores, and passing on south in migration. On October 2 the thermometer dropped sharply 
and all the following day a snowstorm raged. . . . Winter had come.

Thereafter for many days land and water were binding in iron ice-grip. Night after night the unspeakable silence of the great snowland was broken by the awesome, re-echoing sound of rending ice as frozen surfaces strained and contracted relentlessly, and split from end to end in the all-powerful grip of zero weather. Repeatedly, nightly, the eerie sound broke on the near shores to disturb a lone man's slumbers, and passed, with rise and fall of key, boom-boom -booming, away into the level distance of the outer lake, to die in desolate cryings.

By the end of October the land was in the grasp of deep winter, which would rule for five to six months unremittingly.

But winter had been late in coming, for the Indians at Fort $\mathrm{Du}$ Brochet say this was the most open Fall they had experienced in the past eight years. Be that as it may - and I had come to be dubious of all Indian records of timewinter had come, and with it the Caribou.

On November 4, late in the evening, an excited Indian brought news that Caribou had been seen. They had been encountered, north of Fort Du Brochet, coming from the east, and crossing the Cochrane River. He told me, "Plenty deer; to-morrow we kill, and have plenty meat." "Would I go ?" he asked, to my astonishment, while he drank strong tea with me and smoked a pipe.

Now in my experience the Indians (I mean the 
unspoiled Indians of the Far North) test a white man in their own peculiar way before they accept or reject his friendship as good or bad, though they do it so delicately that you may be unaware of their intentions. Observant at all times, they are extraordinarily keen-sighted in reading any mute sign of any phase of nature ; and quickly read character in the face, and in actions. I had come among those reticent Indians a stranger, but ultimately I found that mine was a case that had extreme advantages. Primarily I knew something of Wild Life after their own manner, and could talk to them in their own way; which was generally to illustrate a sentiment or a description through the medium of an object, or a living animal, bird, plant, or element with which they were very familiar. Indians are intensely reflective, and they have strange names for wise members of their tribes which go to show this. I give a translation of two of the best I have heard. "The silent snows are falling, forming signs." . . "He listens to the unseen Rapids." Secondarily, I was not trapping fur, not, therefore, encroaching on the rights to territory which were the red man's by heritage. The research work I did was full of interest to them. For hours I have had Indians squat and watch me skin birds-a proceeding they had never witnessed beforeor skin an animal for remounting : which meant cutting the skin so differently from that of a fur pelt, and the preservation of the limb-bones and skull. Finally, but not the least noteworthy, if you have a mind to humour Indians, on rare occasions I played a few 'pipe-marches on a 
Chanter, which astonished and delighted a people who are passionately fond of music in any form.

How far those little incidents had gone toward making up the approval and goodwill of the Indians I had had no inkling, nor had I given the subject a thought until this day of Caribou arrival. But now $\mathrm{I}$ had been asked to join them on the morrow, and go with them to this secret place the Caribou were passing. I may be forgiven if $I$ was pleased at this certain sign of friendliness on the part of this once-wonderful, fast-declining race of hunters, who speak mostly by actions and rarely by words. Having a great admiration for the intelligence and skill of the good old-world type of Indian-and they still exist in the Far North-I confess I was glad to think that I was to be one of such a party in their hunting; though , I, later, was to learn that the morrow held for me yet another Indian testthe last they ever asked of me.

Thus it came about that in the small hours of the following morning (3 a.m.) a guttural voice hailed me from outside my cabin door and I drowsily extricated myself from out my fur sleeping-bag to open the door and admit icy blast; and not one Indian, but the whole hunting party-a total of seven. They had left the Post half an hour ago and were on their way to the huntingground.... I was to hurry, and come with them.

By necessity in the northland one sleeps in most of one's clothing for warmth, for one had long left behind the land of wardrobes, and blankets, and beds-and so in no time I was ready to join 
the others; fur clad, as all the Indians were, in outer garment of Eskimo kind-a pull-over, shirtlike, hooded upper garment, and trousers reaching below the knee-all native-tanned Caribou hide with the long thick hair outside. On our feet moccasins - that finest of light footwear for fast travelling and stealthy hunting.

I took down my rifle and we filed out of the cabin and started off.

Outside the night-sky was dull and grey, but a fair light was thrown on the snow by the cloudobscured moon, which was full.

Led by Gewgewsh, one of the best and most active hunters in the territory, the party trailed ahead in single file, at great speed and without any seeming effort. With unerring knowledge of "lie" of land, and every nature of obstacle to avoid, those Indians chose the easiest and quickest line of travel to a definite objective ahead. As they travelled one could hear the low tones of their hurried laughter and guttural speech, for excitement was intense among the Indians. They were keen sportsmen, keen as children on an exciting game, and above all they had been talking and dreaming of Caribou for weeks, and they knew that to-day they would kill and have meat at last, and after a summer of fish-food their palates, and the palates of their squaws and papooses, were languishing for fresh meat.

About 5.30 a.m. the party reached a chain of small lakes which it was necessary to cross; unmapped lakes that linked up with Reindeer Lake further south. Those lakes had a strong current running through them, and because of this 
current the Indians would not risk crossing on the lake ice at present-a month later, yes ! Therefore the party halted at a narrow neck between two lakes, through which open, fastflowing water passed. Here it was planned to cross by raft; and speedily, with the faultless precision of men who knew exactly what they wanted, some trees were felled and the construction of a raft begun. Eight stout logs were cut and laid together over cross-poles at either end and bound firmly in position. This done another tier of logs was placed on top so that the total timbers would float the weight of a man. The completed raft was about $2 \mathrm{ft} .6$ in. $\times 9 \mathrm{ft} .6 \mathrm{in}$. Satisfied all was then in readiness to go forward, and as time was not pressing, for it was still night, everyone adjourned to the blazing fire which two of the Indians had kindled, and partook of tea and food. How welcome was fire and tea in the bitter cold morning to both Indian and white.

The picture about the fire was striking. A group of fur-clad, gracefully athletic-looking Indians standing or squatting near their firearms beneath the gloom of dark-boughed spruce forest which night had not yet left; feather-flaked snow falling lightly, stippling the air in its sustained, unhurried descent, and whitening the hooded heads and shoulders of the men; inside the circle leaped the eager flames of the log-fire, lightening the underside of the nearest snow-laden spruce boughs, and casting a glowing touch of light on the meditative, strong, bronzedark faces of the Redskins. 
Before long it was decided to move on. It was then close upon dawn, which would be about 7 a.m., and clear daylight about 8 a.m. The raft was carried to the water's edge and floated on the stream, a rope attached to it, and then Gewgewsh poled his way skilfully over to the opposite shore. Once across he tied another rope to the raft ; and then, by see-saw method, it was pulled from shore to shore, each time carrying from one side a single passenger, until all were across.

Once all were on the far bank conversation ceased and the party moved quietly inland expectant of soon meeting Caribou. Coming, after a time, to a small inland lake, the first indications of Caribou were found-fresh hoofmarks on the smooth snow surface. Thereupon the party changed its composition, Gewgewsh and another Indian going off in a north-east direction to follow up the fresh tracks, while the main party continued south-east. The two hunters had barely left us when we heard them commence to shoot. Six shots they fired; one of which hit the object, as was easy to infer by the odd sound of the dull plunk of the bullet as it struck home. Soon the main party sighted Caribou-three bucks on an open pine-wood hillside. Upon those a regular fusilade of ineffective shots was fired by the excited Indians; and then a general rush to head them off, as they crossed running west, and more shots during which one Caribou was brought down. The animal was cut and disembowelled where it had fallen, and left unconcernedly to be gathered 


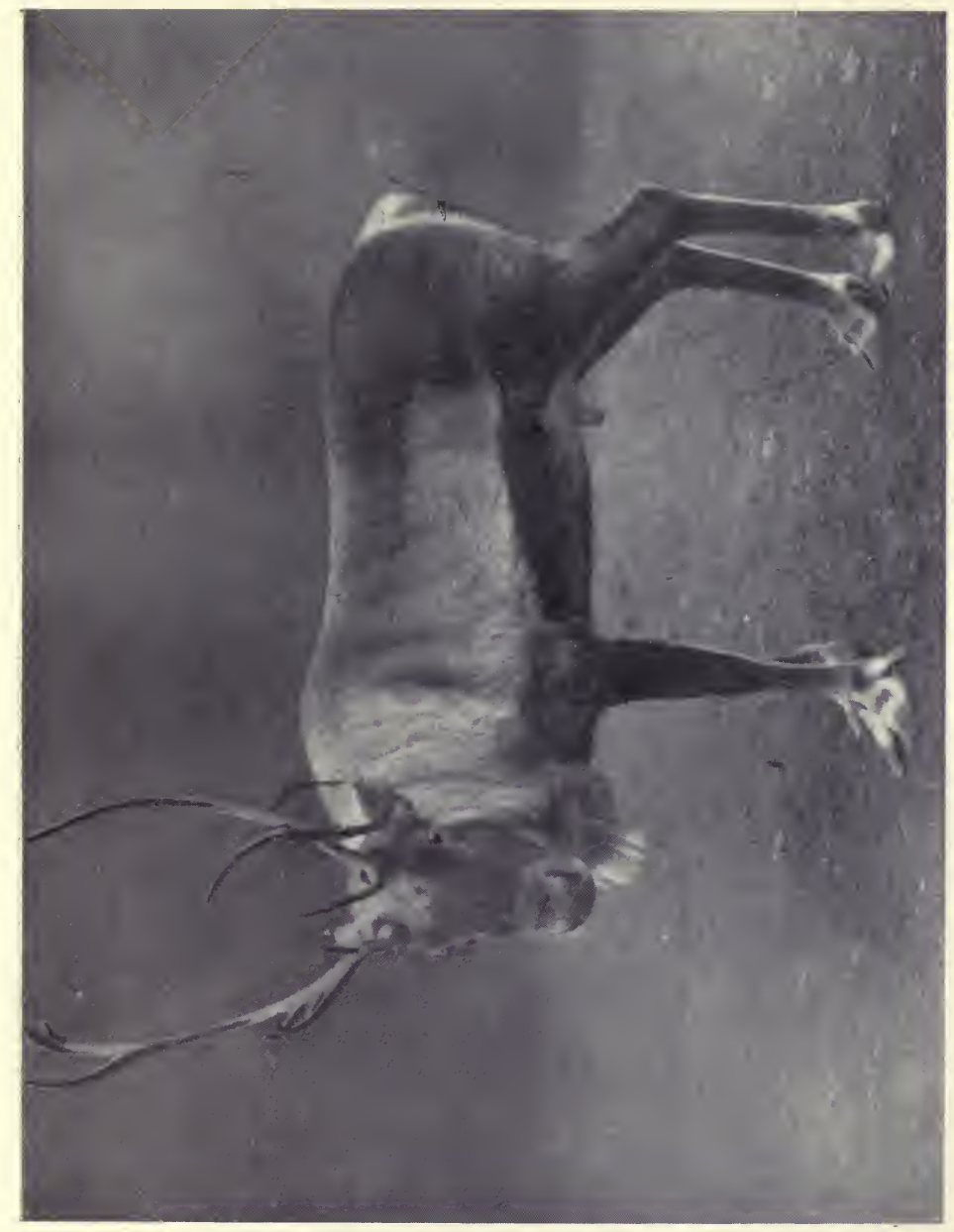

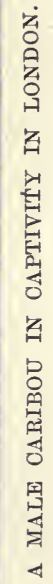

$\stackrel{\infty}{=}$ 

later without an apparent glance to establish its location in forest that I would have had to blaze a tree or two and take careful bearings if I was to be sure of ever finding the spot again. The shooting of the Indians-never brilliant-up to the present had been particularly bad. They are, however, seen to better advantage when hunting more or less alone, and when not unbalanced by over-eagerness to secure first blood; as they this day were. Continuing, the party shortly afterwards again dismembered; three of the Indians going off south-east, and the remaining two and self heading now more south-west. We sighted two Caribou standing in an open space, but they jumped off into the scrub so hurriedly that it was impossible to shoot. About this time the two Indians with me (the man who had asked me to come and another) appeared anxious to go off by themselves. Until now I had been an interested spectator, but not without inner excitement and inclination to try my luck, so suspecting nothing, and assuming we would meet again at the raft-crossing, I wished them good luck and struck into the forest alone. I had gone no great distance before I came on three, or four, Caribou feeding in low-lying scrub forest. Among them was a fine buck, and this animal I succeeded in bringing down, while the others vanished through the timber. My quarry was not dead, but it was not difficult to track him to where he had collapsed in a muskeg bottom a short distance away, and dispatch him with a fatal shot.

It was then about 10 a.m. It was still snowing, but less cold-not a bad day to stand about in; 
and as the Caribou was a fine animal I decided that this was a good opportunity to secure a museum specimen. Therefore I gave up further idea of hunting, got a good fire going near the carcass, and set about comfortably skinning the animal. I got through with my, task sometime about 1 p.m., having then the head, limb-bones, and skin complete. I then drank a refreshing brew of tea, for one always carries a pan for that purpose, and prepared to go back to the raft. I had brought my camera out, and food for another day : this weight I discarded for the time and left beside the carcass of the Caribou before I covered it over with a mass of 'spruce branches to frighten off prowling animals, particularly timber-wolves. The raw hide and limb bones and antlered head were then made into a pack and I started for home from a place I had never seen before and that I had entered with the guidance of Indians. Had it not been snowing my return would have been arrived at simply by following back on my old tracks, but these were covered an hour or two ago. However I had no doubt about the main direction, and about 3 p.m. I was at the narrows. Not knowing the country, I was at fault in meeting obstacles which I lost time in getting round, and, indeed, finally reached the chain of lakes below the narrows, having to work up-shore until I came to them. To my astonishment, when I reached the narrows, I saw that the raft lay across on the opposite shore. The Indians had gone home! They had not waited for me!

Not then, but later I learnt that they had done 
so to know if they could trust me in bushcraft. It was a test-perhaps a stern test-for think of it if $I$ had been a tenderfoot, and lost, and out at night in bitter cold; probably they did not even know if I had matches to make fire : if one had not, God help him!

There was nothing for it now but to face the crossing and endure a cold plunge, so, with my pack held high, I waded into the icy water, which I was glad to find came no higher than my chest, and I was able to cross without swimming, which would have been an even more unpleasant experience, with the current and heavy pack to deal with. Thereafter I passed onward to my cabin at a hurried pace to keep up circulation, so that my body and limbs would not be frozen. I reached my destination about 5.30 p.m., shortly after dark - and none too soon, for by that time the garments that had been under water were frozen stiff and rasped awkwardly against my limbs, while alarming cold was getting at my body.

Later in the evening I tramped through the woods into Fort Du Brochet and the Indians were glad to see me. I noticed, though I then knew not their purpose, that they exchanged furtive glances, but made no remark that might infer that my appearance was other than ordinary. ${ }^{3}$

At the Post the day's experiences were re-

1 I may here say that from that day I went among the Indians, and hunted and travelled with them, and knew I was henceforth accepted as one of themselves, and was given a Chipewyan name which meant "Caribou Antler" - a thing that was thin, but hard and strong. 
counted, and I heard that the total Caribou killed numbered fifteen.

My observations of the day record: The wind was from the south and the Caribou were travelling up-wind as is always their custom... . Ravens plentiful, following the Caribou.... Saw one fox, and heard another barking in thick timber.

Before daylight I was out again next morning back on my tracks of yesterday to bring in the fresh meat of the animal I had killed. At the narrows I took off my clothes before crossing and carried them over on my head. It was bitterly cold while undressing and while in the water, and I was so frightfully numbed and helpless by the time I was again dressed that I hastily kindled a $\log$ fire and cowered miserably over it until circulation returned. I had been foolish in undressing, but heated with travelling the trail from the cabin to the narrows I had underestimated the cold, and all but suffered frost-bite for my folly. After careful travelling over the ground hunted over yesterday, I got out to the neighbourhood of yesterday's kill and soon located my cache, though snow had covered it since I had left, and it was well I hâd blazed a tree or two for guidance. I thereupon made a pack of my camera and as much meat as I could carry, and started homewards again.

About midday I threw down my heavy pack, and made fire for a meal on the margin of a small lake. It was a good place to see Caribou if any were near, and before I was half through my meal I looked up from my seat by the fire to see four 
animals trotting across the ice. These $I$ at once commenced to approach and succeeded in wounding a young buck. When I came up to him he was not dead, but I thought he was helpless, and was carelessly approaching him when, to my astonishment, he rose and plunged at me. $\mathrm{He}$ had only antlers about the size of an adult doe, and I managed to avoid them, though his side brushed heavily against me as he passed. It was an action of despair, however, for the poor brute went no distance before he collapsed again, and I despatched him with a merciful bullet. I killed many Caribou later, but this is the only case when I experienced one of those animals attempting to show fight. It, however, bore out what the Indians had told me, for they said such a thing sometimes happened. After returning to my fire and finishing my meal, I cleaned my kill and left it lying, after covering the carcass with spruce branches as before.

It is strange to you, no doubt, but true of one's ordinary habits in the North, that it was fully two weeks later ere I trailed with dog-team to this lake, uncovered the cache and cut up the frozen carcass with an axe to load it on the sled; then, moving on to collect another hidden animal at another distant point, finally to carry them back to my cabin for food for my huskies (sleddogs).

However, to return to my pack : after caching the Caribou, I loaded up and continued homeward. On the way I encountered three more lots of Caribou but did not molest them. It is noteworthy that the wind was from the north 
this day, and the Caribou seen were all travelling north, up-wind, though it meant that they were going opposite to the direction they had been travelling on the previous day. The big lake (Reindeer Lake), which strong winds keep in motion after smaller lakes are ice-bound, was not yet completely and solidly frozen up, and the Caribou appeared to be feeding around the northeastern shores, possibly waiting to get out to the extensive surface and reach the rich feeding grounds on the countless islands. On the other hand the direction of the wind seemed to have strong influence on their movements.

Regarding pack-carrying, which I am reminded of by the burden this day carried, I kept the meat load intact that I brought in, which I had packed for five hours-possibly, in that time covering a distance of some twelve miles-over hill and muskeg, and through snow; and next day had it weighed at the Hudson Bay Post. It was $65 \mathrm{lbs}$. This is a fair load-a load that strained me to carry it the prolonged distance.

I am not physically a strong man, but I had been all summer on the canoe trail and was hardened and inured to the toil of portaging overland at bad rapids or inland to lakes. Judging things by the weight of the above pack I would say an able Indian could comfortably burden himself with 80 to 100 lbs. for a long distance. To expect him to carry more, if he was in your service, would be unjust, though I have found good Indians will attempt carrying excessive weights rather than admit the smallest sign of weakness to a white man. 
A pack load is a bundle bound firmly together after the shape of a flour sack, and a half-circle of cord, or leather thong, is formed into a carrying strap, so that when the pack is hoisted high on one's back between the shoulders, this cord is slipped over to the forehead, and rests there, and thus sustains the load in position, leaving the hands free to carry your rifle and assist in easing the pressure of the load from time to time. The chief strain you will feel, if you are unused to the pack trail, will be on the back of the neck, for the weight of the load is heavily on your forehead and tends to strain your head backward. Of course if your strap, or "tump-line," is of rope, a pad of cloth or grass will be placed between the rope and your forehead to prevent its cutting into the flesh. A made leather tumpline has a broad web where it passes across the forehead.

Those experiences I have recorded are similar to many that followed during the winter, too numerous to describe in detail.

In time I had secured, for museum purposes, handsome specimens of the Barren-ground Caribou in winter coat-an adult male, an adult female, and a yearling fawn (male).

To give an idea of the size of these animals, the male measured forty-eight inches from hoofs to the highest part of back (the haunch), the female forty-two inches, and the fawn thirty-seven inches. In colour the winter coat of the male is: Back, sides, legs, and head, medium dark umber-brown; fore-shoulders, and entire neck, above and below, dull white; tail shows white 
when erected, as it most often is (it is, however, brown on the upper side); breast and belly are brown like upper parts, but turning to white toward rear, between hind legs. A grey strip (a mingling of the white and the brown hairs) runs horizontally along the middle sides from the white of the shoulders to within eight inches of the hind-quarters; ears and upper forehead, grey. The adult female is, generally, much lighter in colour than the male; rear of back, legs, and nose were in this specimen the only parts brown; middle sides, hind-quarters, lower limbs, forehead, and ears, greyish ; remainder, white. The fawn was very similar in colour to the female. Both male and female have antlers, the males having a great backward, outwardcurving length ; the females short and symmetrical like those of a young buck. In early winter some of the bucks still carry antlers, but the greater number of animals have cast them at that time.

They are graceful animals, particularly graceful when they are in alert motion, and carry fine suggestion of indomitable pride. They trot with easy, swinging, far-reaching strides, with movement lithe and muscular. The forefeet are flung high with sharp-angled knee action (like a well-broken hackney), while the hindlegs stretch well back before they thrust the body forward. Caribou sometimes start off, if frightened suddenly, by rearing in the air with a powerful spring of the hindlegs.

The track of Caribou on snow is a line of single hoof-prints running out one point directly in front of the other-not any two hoofs together- 
not any hoof-print on the left side or right side. A typical measurement of the span between hoof-prints is twenty-five inches, from front of one hoof to rear of the next in front; an ordinary hoof-mark measures four-and-a-half inches by seven-and-a-quarter inches. The above of course refers to the track of a single animal. Caribou are much given to follow in Indian-file one after the other, and soon tread down a regular path of footprints in the snow.

During the next two months I travelled through regions that were wrapped in resolute Arctic winter, vast regions formidably hushed, incalculably desolate; more completely impoverished of life and activity than any words can depict. One moved in a soundless land, a land that was deaf and dumb and had no organ of expression; and one could understand, while living in this place of dead, why men go mad under the awful shadow of utter loneliness, and under the unspoken, fanciful questioning which unmitigated space will prompt and throw back unanswered, touched with a sense of discouraging mockery. In many places there are not even Caribou; not one single moving object in a day's trail over dreary snowfields. In such regions, in deep winter when the thermometer is anything from ten to sixty degrees below zero, one's salvation is companionship. At such a time I have learned that it is folly to go beyond the last outpost without a comrade, even if that comrade only be an Indian - and there is no finer, more unselfish comrade on a hard trail than just an Indian. Starvation, sickness, frostbite, madness : any of 
those might carry one "across the line" in but an hour or two if one was stricken when out alone in the all-forsaken land of merciless cold.

However, to return to the Caribou and the main object of this narrative, during my winter travels I was fortunate to see thousands upon thousands of those graceful animals.

Once in particular I witnessed the purposeful migration of Caribou. This was when returning in December, short of food and short of sleddogs, from the region of the Barren Lands, where no Caribou had been seen. Indeed, not one animal was encountered north of the locality I speak of, a point about sixty miles north of Reindeer Lake. Here one morning, after camping overnight on the edge of a small lake that only had a range of view of about a mile, from daylight until I struck camp about 11 a.m., I witnessed countless herds of Caribou crossing the lake in a south-easterly direction-one herd following another, company on company, regiment on regiment: and they were still passing when I left. It would be impossible to estimate them. One could not tell where the column began nor where it ended, nor if similar columns were passing behind us to the north or beyond vision in the south. I attempted to count some herds as they crossed; one numbered close on one hundred before it disappeared into the forest and I could count no further. Many were bands of between twenty and forty. All appeared intent on travelling, and were, as far as one could see, all does and fawns. The Indians assert that the does and fawns are now moving north again 
(December 20), and say that this is about their usual time for doing so. However, the migration I witnessed was going south-east, as I have said, though I cannot deny that if the wind veered to the north they would almost certainly swing in that direction. I have come to the conclusion that they always travel up-wind, and that they only gain distance in whatever determined direction they are travelling by going forward more rapidly in a favourable head-wind, and returned more slowly on an adverse head-wind. It appears to me something like incoming tide on the seashore ; waves washing forward and drawing back, but ever reaching further and further up the beach to the distance they are set to gain. I believe the strongest motive the animals have in travelling up-wind is a very simple one, that of comfort and warmth(as a seabird riding the waves), since the wind then blows the way the hair lies on the animals. A further motive is that in thus travelling they are assured that their keen scent will warn them if they are approaching danger.

Caribou I also conclude are rather an elusive quantity. They may be here to-day and gone to-morrow, and not an animal may be seen in a certain locality for a week or two weeks. Then one day you may find they have returned-or is it a fresh lot arrived? In December there were no tracks or signs of Caribou north of latitude $59^{\circ}$. Southwards, between latitudes $58^{\circ}$ and $59^{\circ}$, the great herds above mentioned were encountered. Yet when I got into Du Brochet Post again (a little south of latitude $58^{\circ}$ ) the Indians complained 
of the Caribou being very scarce, and all were anxious about meat. In January I travelled south on the great sea-like area of ice-bound Reindeer Lake. At that time Caribou were plentiful on the lake except toward the south end, where there were few, and the people at the Hudson Bay Post then had very little meat. Possibly Caribou came down after I left, for I believed the bucks to be still working south.

However, the Indians tell "me that when the Caribou fail to pass their neighbourhood as they have been accustomed to doing, they are sometimes forced to travel and camp in a favoured locality so that they may kill their winter store of meat and not starve.

Whenever I had the opportunity I closely questioned Indians regarding the numbers of the Barren-ground Caribou, and every individual was agreed that in the neighbourhood of Reindeer Lake and in the territory north of it, those animals were more plentiful in 1914 than in former days. There is one factor which perhaps accounts largely for this increase of Caribou, and that is that the Chipewyan Indians who inhabit the territory directly south of the Eskimo country, and who are called in their own language "The Caribou Eaters," are fast dying out, victims of interbreeding and consumption. It is sad, but woefully true. Philip Merasty, an old halfbreed, 61 years of age, who, when a child, came with his people from Ile à la Crosse to camp at the north end of Reindeer Lake, whence plentiful Caribou meat had drawn them, told me that when he came there were then three hundred Chipewyans in the 
$\mathrm{Du}$ Brochet territory, and in 1914 they numbered less than one hundred. If one estimates the Caribou kill, per male Indian per winter, at about forty animals (which is a common average in my experience, though it exceeds by double the number Thompson Seton estimates in his book The Arctic Prairies) and takes the adult male population as about one third of the whole population, one arrives at substantial figures which show, in a broad sense, how much less destruction is taking place among the Caribou at the present time owing to the decrease in Indian population. I arrive at figures in this way: If in 1864 100 Chipewyans killed 40 Caribou per head the total kill was 4,000 Caribou, and if in 1914 34. Chipewyans killed 40 Caribou per head, the total kill was 1,360. Therefore, at a broad estimate, 2,640 fewer were killed in that area in 1914 than fifty years ago; and each year the conditions are improving-for the Caribou. Moreover, the territory I speak of is at present far beyond the reach of the white hunter, and is likely to remain so at least for another century, so that there is no incoming race to counterbalance the outgoing Indian.

When first encountered the Caribou were feeding on withered marsh-hay, growing sometimes with tufts still above the snow, along the edges of the countless land-locked lakes ; and on moss of a pale greenish-white colour which grows on sandy hills, or more luxuriantly in low-lying muskegs. Later they fed on similar food, but had to dig through the snow for it-as I have previously described. In bad snowstorms the Indians say the Caribou yard together after the manner of 
frightened sheep, and that a man can walk in among them at such times; but this I have not witnessed. The Caribou invariably feed up-wind, as I have said, and travel overland through the woods from lake to lake along chosen paths long established. It is common about noon, when the animals are resting after their morning feed, to find Caribou out in the centre of a lake, lying down or grouped about resting in the sunlight, while the watchful old leader scans the open snows on all sides, and sniffs the drifting wind.

If you have found Caribou country in winter, and can put up with intense cold, you will find that the actual shooting of these animals is not difficult. They are stupid animals once you have frightened them with a shot, and if you get within reasonable range of a band on a lake you are certain to bag more than one of them, if you are anxious to secure meat or particular trophies, for if you bring down one with your first shot, and run on when they run, the others will almost certainly halt before they have gone far to look back for their comrade or to make certain where danger lies, and you will have opportunity for further shots. To give an instance of this : on one occasion a band of twelve Caribou came on to the lake where my cabin stood. This was bringing dog-feed to my very door if I could effect a kill - and the distance you have to carry meat from the point you kill to your camp is no inconsiderable detail if time and labour and sled-dogs are to be saved. Therefore I snatched up my rifle and a handful of cartridges and eagerly gave chase. Before long, by hard running and quick 

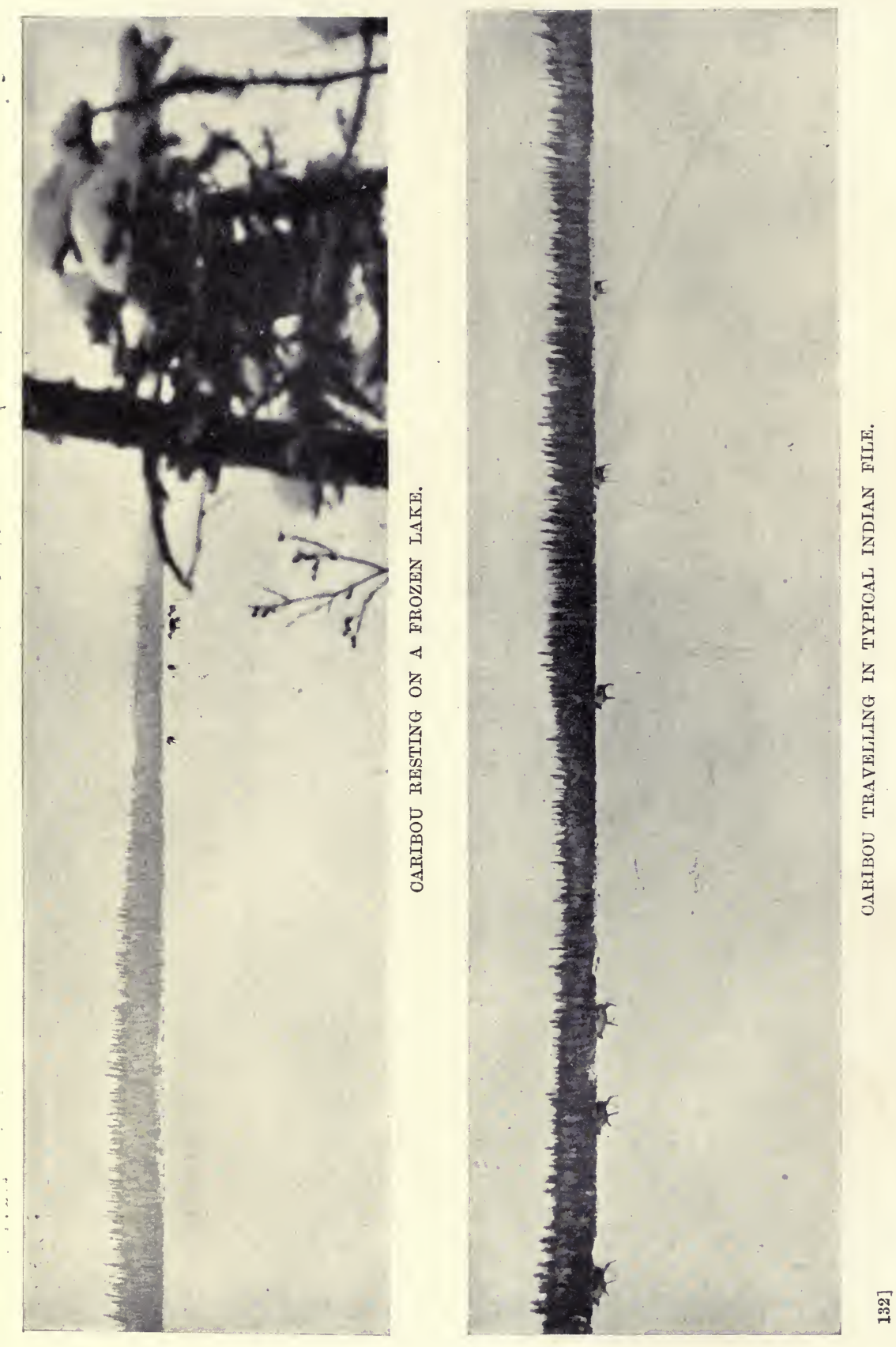

shooting, I had six carcasses lying one beyond the other in wake of the confused sheepsilly band, before the Caribou got into the forest at the north end of the lake; and if cartridges had not given out I believe very few would have got away. This illustrates what I have said, and what I have often experienced, for each time I fired the band started away, and I after them, until they made that fatal halt to look back, when I would halt also, and pause to fire againand so on, with the above result.

The best range at which to shoot Caribou is, in my experience, inside one hundred yards, and to shoot to kill the animal with a clean shot, for a wounded animal, badly hit, that gets away, is not pleasant to think of, especially as one may know that the poor animal will freeze to death once it ceases travelling. Again, a wounded animal that you might follow may take you miles off the course you happen to be travelling, and through overgrown country that you cannot afterwards take a dog-sled into, to gather the meat, in the event of your killing the wounded animal.

I have killed animals outright with $\cdot 303$ Ross rifle at 312 paces, and 447 paces, when I had no alternative, but, irrespective of marksmanship, those distances are too great to make certain of clean kills. Shooting in intense cold, unless you have a special-fingered glove and can shoot with it on, you will almost certainly get the fingers of your right hand frozen, if you fire more than one or two shots in succession with the bared hand which you have taken from the heavily lined deerskin mitten. I've had all the fingers of 
my shooting hand frozen, sometimes down to the second joint, but if attended to at once and thoroughly chafed with snow there are no serious consequences-nothing but the sharp pain of reviving circulation, and, sometimes, the skin will afterwards blacken and peel off.

I turn now to the Indians, and the extent of their Caribou hunting. It has been said that Indians kill less with modern weapons than they did in the past by primitive methods, but I think such a statement should be taken with reservation. I grant that Indians, as a rule, are indifferent marksmen, but it is well to remember that what they lack in that respect they more than make up for in bushcraft. They are undoubtedly skilled hunters, keenly intelligent hunters with a second sense-a wild sense which is essentially Indian and which makes it possible for them to get very close to animals, much in the crafty, patient manner of prowling wolf or fox that manœuvre to outwit and come within striking distance of their prey.

On October 21, 1913, an Indian of Fort Du Brochet was returning after dark on the ice of Reindeer Lake, after setting out a trap-line, when he heard the muffled thunder of countless Caribou passing north-east over the ice. No Caribou had been seen until then. It was the hour of their coming. This Indian got back to the Post in great excitement and soon spread the glad news among the half-dozen cabins on the lake shore. The following morning at the first faint light of dawn, the hunters of the settlement went out to kill, while the Caribou con- 
tinued to pass all day over the same route which herds had been tramping over all night-a route which was in full view of the Post when day broke. During the hunt that followed two Indians killed sixty Caribou, and three others, forty-four Caribou : a total of one hundred and four Caribou to five rifles. This was a good kill, for the conditions were perfect, since the Caribou had been found in the full flood of their migration, and no distance from camp. And is it not a better bag than five men would obtain by snare, and spear, and muzzle-loading gun, in primitive hunting ? for, as I describe below, it apparently took a much greater number of men to effect any like large capture in the past.

The method of killing Caribou in numbers in the past, in the territory immediately south of the Barren Lands, I here recount as more than one veteran Indian has described it to me: In olden days Caribou were largely caught in snares. The Chipewyan tribe in the whole neighbourhood combined in one grand hunt at the season of the Caribou migration. It was their custom to select a locality in the forest which they knew to be much favoured by Caribou, and there set snares, made of stout "babiche" (leather thong), by hanging them, at a height to form a head noose, between stout trees wherever old Caribou paths passed. They would set a hundred or more snares in this manner before The Trap was complete; whereupon the hunters who were armed with spears and muzzle-loaders took up their positions so as to watch the trap and encircle it when the Caribou approached. Thereafter 
they set themselves to wait and watch for the approaching herds, and sometimes they had to keep vigil for days. When Caribou came a large number were allowed to pass inside the watching cordon of Indians, who then formed a wide ring and commenced to humour them onward into the way of the snares. When the animals were fairly entrapped the Indians would close in from all sides, driving the Caribou to their doom, and shooting them down or spearing those that tried to escape. Sometimes none of the herd escaped (asserted to be as many as two hundred in some instances), all falling prey to the Indians' skill and active watchfulness. If one bears in mind the sheep-like tendency of Caribou to lose their heads when thoroughly alarmed, it will be understood better how hunting in this manner was practicable to men with endless resource in bushcraft.

Caribou, which are strong swimmers, are also killed in numbers when swimming lakes in their early Fall migration. Some Indians on the borders of the Barren Lands make kills in this way, but they are principally made in the Eskimo country, where the Eskimos, in their frail, activemoving kayaks, surround a herd of animals in the water and spear them to death.

Having cited those large kills of Caribou, past and present, I might be asked, 'Why such wasteful destruction? In answer, my experience bids me defend the Indians, for of all the Caribou I have seen shot by Indians (no inconsiderable number) I have never known of one being wasted. In the first place it is well to remember that 
the Chipewyans look on the Caribou as a thing sent solely to them by $\mid$ The Spirit, to feed and clothe them through winter. Caribou are essential to the existence of those people, for the Chipewyans depend largely, almost completely, on them for winter food, though otherwise absolute poverty is relieved by limited stores of frozen fish, and what few fish are netted below the ice. If one hears complaints at all, it is that not enough Caribou can be found: never that they have too many and would leave some to waste. There is greater use for large quantities of meat than one, at first thought, might imagine. Indians are voracious eaters at all times, particularly in the intense cold winter weather, and they eat Caribou meat extravagantly when they have it, and eating it, and it solely, three or four times a day, as they often do, a single animal is soon devoured. Then, too, and this is the chief factor to be borne in mind, Caribou are extensively used for dog-feed whenever procurable in numbers. If an Indian has ten sled-dogs to feed, one carcass cut into portions will barely feed them for three nights; the number of dogs is more often twenty, sometimes thirty or more, and the call on the food-supply accordingly greater. So it will be seen that, though Indians kill large numbers of Caribou, they have a definite need for them in a land where food is not bought; where red men wrest a livelihood from rivers and lake-waters, virgin wildernesses, and dreary snow-wastes; and where to be without food is to die.

It is hardly necessary to say that the flesh of 
the Caribou is splendid food. The choice parts the Indians select, when opportunity occurs, are the tongue, the heart, the kidneys, the brisket, all fat, and the limb-bones (after most of the meat has been removed) for the marrow therein. The tongue is undoubtedly the choicest part of all, and a delicious delicacy. In past days the Hudson Bay Company used to send out from $\mathrm{Du}$ Brochet Post many tongues and barrels of Caribou fat.

Indians, as I have already said elsewhere, have an observant and very intelligent knowledge of wild life. This is borne out in the Chipewyan manner of speaking of Caribou, when hunting them. They will not say, "There is a caribou," but will use a name which describes its individuality as well, since they have a series of names which discriminate at once the condition, or age, or sex, of the animals they encounter. Thus names mean: "a fat Caribou," "Caribou in poor condition," "a Caribou doe in fawn," "a young fawn," "a yearling Caribou," "a threeyear-old Caribou," "a five-year-old Caribou," "a doe Caribou," "a buck Caribou" -and so on.

As well as providing the Chipewyans with great stores of winter food the Caribou supplies them with skins for clothing. In the past, Caribou skins furnished them with all their material for clothing and the covering for their teepees. Now, when they can, they get white man's clothing, and canvas for their teepees, in fur-barter with the Hudson Bay Company and Revillion Brothers-a change which is decaying native skill and native beauty. There are 
still, however, smoked Caribou-skin teepees in use, while winter fur clothing, and moccasins made from Caribou hides, are universally worn. Summer clothing-top-boot leggings and shirts, made from flexible native-tanned skins, are now entirely out of use.

Caribou-skin products are prepared by the Chipewyans as follows :

Babiche.-Long lengths of tough leather lace, or thong, made from raw hide. Process of preparation: hair scraped from skin; skin dried; then skin soaked till soft, and cut into long strips by circular cutting. Skin in nowise prepared by the lengthy process required when dressing skins for moccasins, etc.

Skins dressed as Soft Leather.-Lengthy process requiring, chiefly, industrious hand-working. Skins soaked, and dried in the open air, and worked with hands; process repeated many times, each time becoming more soft and more white. When lying out, the clear, fresh air purifies the skins, as in ordinary bleaching. Skins finally soaked and rubbed in a solution of Caribou-brain (in the absence of brain ordinary soap is used): brain contains grease, which has the essential softening quality. The skins, when finished, are very soft and flexible like Chamois leather, and are, particularly if they be fawn skins, often pure white.

Dressed Fur Skins.-Hide dried first by stretching on the circular inside of teepee-thus drying by the heat of the fire alight on the ground in the centre of the interior; ; skin then rubbed with brain (or soap) and worked clean of all flesh, fat, 
etc.; a little water is applied during process of rubbing, but skin never allowed to become very moist. Inside skin soft and flexible when finished, and the outside hairs, untouched.

Caribou-hide is best (thickest) in spring, and no good in mid-winter (being then thin). The hair, apparently, feeds on, and derives nutriment from the skin, for when the hair is long in winter the skin is thin, and in the spring when the hair is new and short, the skin is thick and at its best.

Before leaving this subject I will endeavour to tell of a few experiences of photographing Caribou : experiences that were not very successful, because of the action of intense cold on the focal-plane shutter, but which give considerable detail of Caribou habits and winter hunting.

It was with old Philip Merasty, a halfbreed, and Eaglefoot, a Chipewyan, that I made my most determined attempt to photograph Caribou; and the last attempt I made, since cold and unsuitable apparatus completely baulked me from further effort.

Philip, without knowing it, was, like many an Indian, an unread wilderness naturalist. The clouds, the water, the fish, the land-the forests, the birds, the animals-all in his country he had studied for a lifetime, and, at ripe old age, he was full of wisdom of the wild. He had watched me skin and label specimens, watched my manœuvres to take wild-life photographs, watched my making pencil sketches; and in time had proved himself a staunch confederate in assisting my researches.

Eaglefoot, perhaps, had equal knowledge, but 
he was silent, almost, as the snow. Half a dozen words with Philip in the morning would decide a day's plans, and half a dozen sentences over the camp-fire at night record all the day had accomplished. But he was a splendid hunter and traveller, and a hard worker if there was work to do.

Neither of those Indians had ever seen a camera before they saw this one of mine, and to allow them to look through the view-finder or focusing screen afforded them great astonishment and delight, when they beheld the miniature pictures in the glass. It seemed to them witchcraft. They expressed the same excited astonishment in looking through field-glasses.

With those two Indians, and food, sleeping bags, and two dog-trains, we one day set out from my cabin to travel and camp on Caribou ground. And the days that followed I here record from the simple pages of my diary-written at the glowing log-fire o' nights, where comfort was before one, and cruel, hungry cold a yard beyond the camp circle. . . .

Philip and Eaglefoot outside my cabin at daylight (8 o'clock). I joined them in a moment, and we sped merrily away in a northerly direction over well-packed lake surface: the dogs fresh, and the sled-bells tinkling cheerfully.

Soon after starting Philip looked gravely into the even-toned, grey sky and prophesied that wind would rise, while to me the sky in that phase was unreadable. In a few hours wind did risekeen north wind.

On the trail outward Philip looked at his trap11 
line; traps set for Fox, Marten, and Mink, but none contained quarry. I came on a few Spruce Grouse, while halted, and while Philip was examining a Fox set, I, to Eaglefoot's astonishment, shot one with my catapult. He had never seen my "noiseless gun" before, and picked up the dead bird to examine it and reassure himself that I really had struck it to death.

Proceeding we travelled north up a long inlet bay to the north-east of Fort Du Brochet, thence over one long portage, and then through four small lakes and on to a big irregularly shaped lake named Sand Lake.

At first fire the sled-bells were removed from the dog-harness, for they are never used when serious hunting begins; obviously because of the sound.

Soon after first fire (three hours out-the first rest for dogs, and fire for a drink of hot tea), on entering Sand Lake, twelve Caribou were sighted, but they were, a moment later, disturbed by an Indian, who appeared ahead and gave chase. Before long, however, they doubled back towards our party, and Philip shot once without effect. When nearing the end of the north bay of this lake, about forty Caribou were sighted. At once the dogs were run into forest ambush, and we waited in hiding for the oncoming animals. Ultimately I succeeded in making four exposures of a few of those Caribou, but the main herd went away north-east. When there was no longer prospect of obtaining further photographs of this lot, Philip and Eaglefoot fired on them at 
long range, but neither brought any down. A little later a young buck, which had become separated from the main herd, came back past us, and this I shot for the night's dog-feed.

At the narrows between Sand Lake and the nameless lake beyond it, Philip and Eaglefoot chose a base camp, and the sleds were run into cover on a well-timbered low point of land. We were in good Caribou country, and it was intended to spend some time here and prepare unobtrusively to influence the direction of Caribou travel, so that they might come to pass before the camera.

Our procedure was this: to cut from the forest on the shores armfuls of spruce boughs and lay them, at widely spaced intervals, on the white lake surface of the upper lake to form a thin boundary line. This fence was laid after the tracks on the forested shores had been examined, and the wind considered, and Philip and Eaglefoot had decided that Caribou would possibly come from the west on the morrow. Where Caribou were expected to come on to the lake from the forest a few boughs were placed very close to shore, so that when our quarry stepped on to the lake the strange objects would not be observed until the animals looked back or tried to return by the path they had come. As will be seen shortly, Caribou will not pass near any suspiciouslooking object. Along both shores the fence was carried out, making short cuts across the bays; and after the: shores were laid the slim enclosure was completed by running a line of boughs from shore to shore across the centre of the lake. 
There then remained open, to any animal that might enter the enclosure, only the narrows leading into Sand Lake, where I and the camera would be hidden.

It was night when we had finished and returned to camp. Camp was made snug against the keen wind and bitter frost by building the usual barricade of spruce boughs and snow in a halfcircle, backing the wind; and within the circle, just beyond the length of an outstretched man, a great log-fire was built to blaze merrily (and to die out long after the fur-blanketed forms had gone to sleep). All the ten sled-dogs were tied up this night-an unusual proceeding-to keep them from wandering to the traps on Philip's line, and from chasing any Caribou that they might scent in the night. They were then given the whole of the Caribou that had been killed, and twenty fish - a repast intended to keep them. drowsily contented and quiet on the morrow.

The following morning we were moving about camp before daylight, preparing in earnest for deer-stalking. Any of the dogs that showed inclination to howl or whimper was securely muzzled with rope : the morning fire burned low : the ordinary quiet voices of the Indians sank to hushed whisperings-those precautions even although our camp was well back from the shore and in the shelter of forest where there was but slight likelihood of smoke or sound reaching the senses of any animals that might approach.

A hide for the camera and myself was built of spruce boughs on the outskirts of the point of land, and commanding the lake at the entrance 
to the narrows where the Caribou were expected to pass. The hide was built as small and insignificant as possible, and the outside-that which might be apparent from the lake-was sprayed with snow until it resembled the natural surroundings. The first two hours of daylight passed uneventfully, and it was not until about 10 a.m. that two Caribou were sighted. These animals came on to the ice south of the narrows --they had come off the shore past the camera -but the cunning Indians had foreseen the possibility of this, and a few spruce boughs barred the narrows, some distance beyond my outlook. At this fence the two Caribou were turned, and after a long wait they began to approach the hide. Of the leading buck I obtained one good exposure, and though slight was the click of the release the animal heard it, and swung round as if he had been shot at: there he paused for a second, proud head up and great eyes alarmed, while I remained motionless ; but in a moment more he turned and retraced his steps, smelling the ground suspiciously, while his companion followed.

After this there was a long period of patient waiting-not an easy matter in the numbing cold-and it was noon when the next Caribou were seen. It was then that a small herd of a dozen came on to the lake, and within the enclosure, from the west shore. They were very nervous, probably because of the "fence," and they made one or two short rushes as if they meant to risk galloping through the barrier that lay across the lake-only to come to a halt in the 
end, and to look about wonderingly. The wind was from the north, hence their inclination was to get beyond the fence across the lake, but each time they " funked" crossing between those harmless bits of spruce. Twice the buck that was the leader came half the distance forward to the narrows only to turn back again to the northwest, and mingle with the others in frightened bewilderment. Finally the buck made up his mind, and came for the narrows at a long-reaching trot, neck outstretched, head up and horns lying back over the shoulders. Without a halt he came right on, and I allowed him to pass unmolested-he was well ahead of the othersthen made some exposures of the following line of does and fawns that filed past the hide. They were fine fat deer, Philip decided, after they were past-he had, in his keenness, come quietly beside me to watch also-and he ran back to camp for my rifle to shoot at them, but luckily they were gone ere he returned and he couldn't spoil, by the noise of shooting, what chance there might be of other animals approaching. However, it was then getting late, and the light was failing, and we were on the point of leaving off for the day, when Philip, who had been moving around the shore a little way, came to tell me that a single fawn was approaching. This animal walked all along the fence, smelling the ground where the others had previously passed, and uncertain where to go. Finally it got on the fresh track leading to the narrows and came ahead quickly. As the animal passed I made two exposures, though the light was by then very 
poor. A little beyond me Eaglefoot dropped the poor brute, for food was wanted for the dogs; but one felt one would have been glad if it could have run on, and found the herd it had strayed from. It paid the full penalty for loitering behind.

It was now 3 p.m. and too dark for further camera work. It had been snowing lightly all day, and the light was not very good for making rapid exposures. However, what was really worrying me was the action of the intense frost on the focal-plane shutter. Twice it had absolutely stuck in the middle of an exposure, and twice, also, it had refused to act at all when beautiful Caribou pictures were possible. I was beginning to fear the shutter was going to spoil everything, and that I wanted a very simple instrument to replace this complicated mechanism, to which tiny frost particles clung and jammed the finer workings. Over the evening camp-fire I spent an hour trying to prevent any recurrence of a hitch in the shutter-workings. Before the heat of the fire it worked perfectly, and I laid it aside in the end with renewed hopes for the morrow.

The early hours of night were employed cutting wood, feeding the sled-dogs, and cooking a large meal of Caribou meat. Then we lay for an hour or two before turning in, the meditative Indians smoking, and from time to time piling fresh logs on the huge fire. Over the fire, in the upper flames, hung the ghost-like, blackened head of a Caribou, spiked on to a long green staff that was stuck back in the snow to hold the head 
up in position-and this was the manner of roasting our final tit-bit before going to sleep for the night. They are glorious, those night fires of a winter camp, not only warmth and light, but cheerful withal - the home-fire of the trail, where there is real content in the mind of the wayfarer as he watches the flames that incessantly shoot upward in bright spiral lines to wriggle like snakes into space or snap into tiny floating sparks which die out in the blackness and chillness of the surrounding night.

It snowed heavily overnight, and we awoke in the morning to thrust our heads through the foot of snow that covered us in our sleeping bags : the thermometer had dropped also overnight; and altogether it was in no way pleasant in camp before we got a roaring fire kindled. Fire and tea and breakfast soon warmed us up; and about daylight the sky cleared, and the snow, while a strong biting north wind sprung up.

At breakfast I amused and interested Philip in telling him of a strange dream I had had in the night. It was this : He (Philip) was driving his dog-team in a strange foreign country, when, while he stopped to shoot at something, his dogs ran away with the driverless sled, and it was finally seen careering through the streets of a great city. At this time, by arrangement of the strange freak settings with which dreams are embodied, Eaglefoot and I were coming along a side street in the same strange city when we saw Philip's dog-team tearing past on the main street like animals possessed; both of us gave chase. At a corner, where the sled slewed 
awkwardly, some bales and blankets were thrown out, and with those the exhausted Eaglefoot remained while I careered on. Finally I caught the dogs, but when I came to drive them they would not go. The difficulty - in the dreamseemed to be all because I could not recall the name of Philip's lead-dog. Think as I might I could not recall it. Meantime crowds had collected who had never seen a sled and dogtrain before. They were strange, tall, delicate people who spoke no words I could understand. In the end I led the dogs back to where Eaglefoot waited, and was again loading up the bales and blankets so that we might go in search of Philip-when I awoke ... and my first conscious thought was intensely concentrated on Musquar - the name of Philip's lead-dog. The old Indian was intensely interested in this yarn. In many ways Indians have the naive receptive intellect of children.

But, to return to the work of the day. The drifting snow on the lake had, when we looked out from our hide after breakfast, partly covered the spruce boughs of the "deer fence," and our first task was to travel round them all, lifting them, shaking them, and replacing them. After this we had a very long wait before any Caribou came, probably because our movements around the "fence" had frightened any that chanced to be in the immediate neighbourhood at the time. However, about noon, a single male Caribou came slowly on to the lake from the forest on the west shore, and then, apparently surprised, stood long, watchfully alert. Philip, who was 
with me at the camera, remarked in a whisper, "Him not alone, that's why he wait," and sure enough a little later a doe and fawn followed out of the forest, whereupon the buck lay down to rest on the lake surface. But when the others joined him they walked around uncertainly, not seeming to find the resting place comfortable, and so, in a little time, the buck rose and led on across the lake to the east shore, where all lay down in content. They were now, however, too comfortable for my liking, for after more than an hour's wait at the camera hide, the animals still showed no inclination to move. At last it was decided that Philip should make a wide détour through the timber on the east shore with a view to getting beyond the Caribou, and disturb and drive them toward the narrows. When Philip got round into position (he afterwards gave me the details of his movements) he snapped a small dry twig. Instantly the buck's head, which had been resting, turned in toward the body, flashed sharply upright, and he looked steadfastly in the direction from whence the sound had emanated. Again Philip snapped a twig, and at this the buck rose and faced the sound, then fully satisfied that danger lurked in the wood he half-turned and commenced to trot in my direction. Soon the others rose also and followed, but not before the buck was well away in the lead.

The buck passed very close to the camera, and I repeatedly tried to make exposures, but, alas! the shutter was frosted and refused to work. Then followed the doe and fawn, and renewed 
heartbreaking failure on the part of the camera, while the unalarmed animals even approached the hide to investigate the click of the shutter release, a sound which was apparently curious to them.

This was the end of patience. What use to continue? It needed no further trial to teach me that my focal plane shutter was useless in the intense cold. For the time I must give up. If I lived to return in other years I would know what to bring to overcome the cold.

So the dogs were harnessed into their traces, and we prepared to leave for Reindeer Lake. But before vacating camp the'wily Philip set two traps-one for Marten at the foot of a tree, and one for Fox at the remains of a Caribou carcass. The observant old native had seen Marten tracks on the snow near camp, and he told me "he come seek about camp after we go, that's their way."

About 3.30, when dusk was falling, we led the dogs from the forest to the lake and, muffled in our robes, started grimly homeward over withering snowfields. No one spoke-it was too cold - and the dogs laboured on unguided, knowing the home trail, while their deep breathing blew back and froze whitely to their shaggy coats.

Caribou and Caribou pictures were soon forgotten; indeed, every ambition seemed trifling -everything except the awful cold and the boundless, ice-locked land. 


\section{CHAPTER VII}

\section{SLED-DOGS OF THE NORTH TRAILS}

Withour sled-dogs there could be no winter travel over the great territories of the Far Canadian North, and consequently little or no fur trade. Possibly you have never had occasion to think of such a modern thing as commerce in connection with those great snow-bound wildernesses that lie beyond the white man's country: possibly it never occurred to you that the winter life of Indian and Eskimo could concern you in any way at all. Yet, since to them do we owe thanks for great stores of fur pelts, they touch on our lives in an indirect way even as far " back home" as London, Paris, New York, and in all cities; though few people who buy rich furs over city shop counters picture the drear surroundings in which fur-bearing animals are captured-interminable wastes of snow; intense cold, even blizzard; and lone men with patient wolf-dogs battling against bitter, merciless Arctic winter. Perhaps only Vikings of the ancient Hudson Bay Company, and others of the like who have traded in fur for half a century, really know how much is yearly harvested by the aid of the sled-dog. Just as civilisation cannot to-day do without railways, so the Far North 
cannot subsist in winter without dog-trains; dogs which are the means of gathering from great distances, and long trap-lines, the choicest furs for the markets of civilisation; and that gather also the fuel-wood and winter food that keep alive the dusky-hued races that hunt through the dark months of the year for treasures that are coveted by cultured people.

Let a stranger enter the North; let him come to a far-out fur Post, and he will be wonderstruck at the canine population; for if a Post contain ten hunting Indians it is highly probable that the whole foreground will be dominated by some 120 to 150 sled-dogs. The proportion of man to dog is usually on such an astonishing scale.

It is certain that the stranger will wonder to see such numbers of those uncommon beasts of burden, and possibly he will be somewhat surprised that the natives of the Far North so extensively rear dogs for utility, with much of the same purpose as his own people would rear horses in the civilised South.

And he cannot but remark the striking presence, and stalwart wolf-build of those dogs: some half-wild, disdainful, powerful; beautifully proportioned, beautifully coated; others less handsome cross-strains, rough-coated, unevenly coloured, but brim-full of courage and strong to endure.

To find the true type of sled-dogs, or wolfdogs, or huskies, or malamoots-call them what you will out of those names of the countryone must come to the far-out fur Posts ; for good dogs, like good Indians, lie nowadays beyond the 
outposts of the white settler. That the finest dogs are in the Far North is perhaps due to their untrammelled surroundings, and to the nature of their feeding, for, on the fringes of the Frontier, fish, the chief dog-food, is often scarce, and in demand for human food, whereas in the Far North fish are plentiful and little sought in the clear waters of the countless lakes and rivers that abound in those distant places. Moreover in Frontier settlements, and such Posts where white and halfbreed and Indian intermingle, and are unsettled by more modern enterprises than the old-world, patient, plodding fur trade, the sled-dogs are often outcast when their winter's work is done, and remain through summer no man's care, little better than thieving curs, kicked and abused by everyone.

If you are travelling north, particularly in summer, it is sure to be your misfortune on the early outward trail to run foul of those thieving fellows, who instil in you a firm distrust of every sled-dog in existence long before you have cleared their unhealthy habitat. All sled-dogs steal-even the best of them-but the untended outcasts of the Posts near the edge of civilisation are particular vagabonds. My most memorable losses by dog-thieves-memorable because they seriously shortened my carefully calculated food-store on a long outward canoe journey between two ports - was the loss of a shoulder of dried moose meat, stolen from over my head at night, and a week's baking of "bannock" (sour-dough bread) plundered a few days later from a grub box in camp during a heavy storm. 
It is not uncommon to find an outcast dog, or a lost dog, living along the shores of lake or river like a totally wild animal. Living thus they gather oddments of food from the water's edge, besides what live prey they catch, such oddments as dead fish that are washed ashore, or carcass of duck or gull; sometimes too they chance on a nest of eggs, while if there are berries ripening in the woods they will even devour those in their hunger. It is under such circumstances that one may observe the full reawakened wildnatured cunning of those brutes, for their sense of smell when roaming thus becomes keen and suspicious as a wolf's, and they will examine any particle of food with great care before daring to touch it, as if they feared poison or a trap with all the dread of a once caught, once escaped, wild thing. If you want further proof of how close they are to their wild forefathers, watch them at dusk, cunning as wolf or fox, and as naturally stealing through the pine woods over dry, moss-grown knolls, eyes and ears and nose alert, treading stealthily with head forward and tail straight, ready instantly to pounce on grouse or rabbit or any living thing the highstrung senses may detect.

There is one thing in the way of food that, as far as I know, a sled-dog will not touch, and that is mice. I've seen dead mice lying outside cabins for days untouched, where ravenous sleddogs existed. This is peculiar, because some domestic dogs will eat mice, though it is true they are often sick after doing so.

I have said that all sled-dogs will steal. I'm 
afraid that is true, and I cannot revoke even such sweeping judgment, but what I like about the dogs in the Far North is that they have the grace to acknowledge themselves rascals, for they stand aloof from mankind, half-wild, half-afraid, making no overtures or pretences of friendship - and they steal whenever they can. On the other hand, poor-caste mongrels of the Frontier may sidle up to you in friendly fashion, and you, in good humour, may treat them kindly-then turn your back, and they sneak into your tent and plunder whatever is at hand. This sort of thing can be very annoying, and the only thing to do is to steel one's feelings against all and treat them as rogues-every one.

I will leave now the sled-dogs of the Frontier and deal entirely with the more pure, more attractive types of those that are common to the borders of the Arctic. Perhaps some of the finest dogs I have seen were at Fort Du Brochet, at the north end of Reindeer Lake, where the Hudson Bay Company have stretched a tendril through inland wilderness almost to the line of the Eskimo country, and there established a Trading Post for Chipewyan Indians and those said Eskimos, so that they be induced to bring out the fur of a large inland area of the Barren-grounds and lay it on the rude barter counter of the Fur Traders' Store and purchase in exchange such luxuries as flour, and tobacco, and tea, and ammunition, and beads, and coloured cloths, and all such sort of things as are eagerly sought by simple, primitive natives. Once a year a small band of Eskimos travel south with fur- 


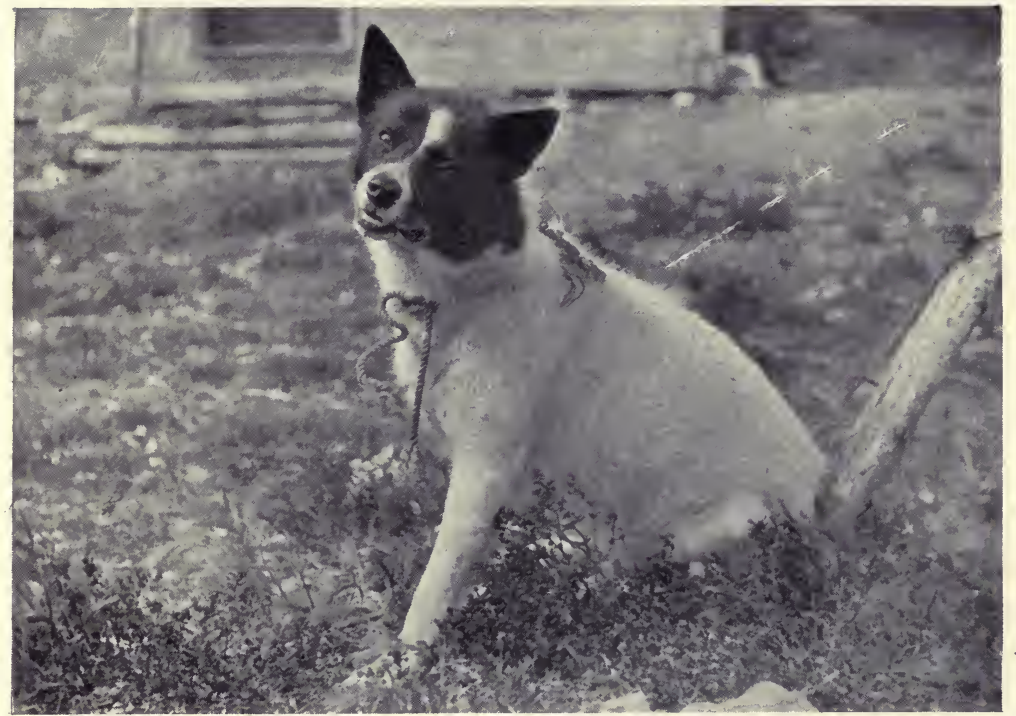

HUSKY DOG.

A fine train-leader, wonderfully intelligent, one of the finest dogs I ever encountered.

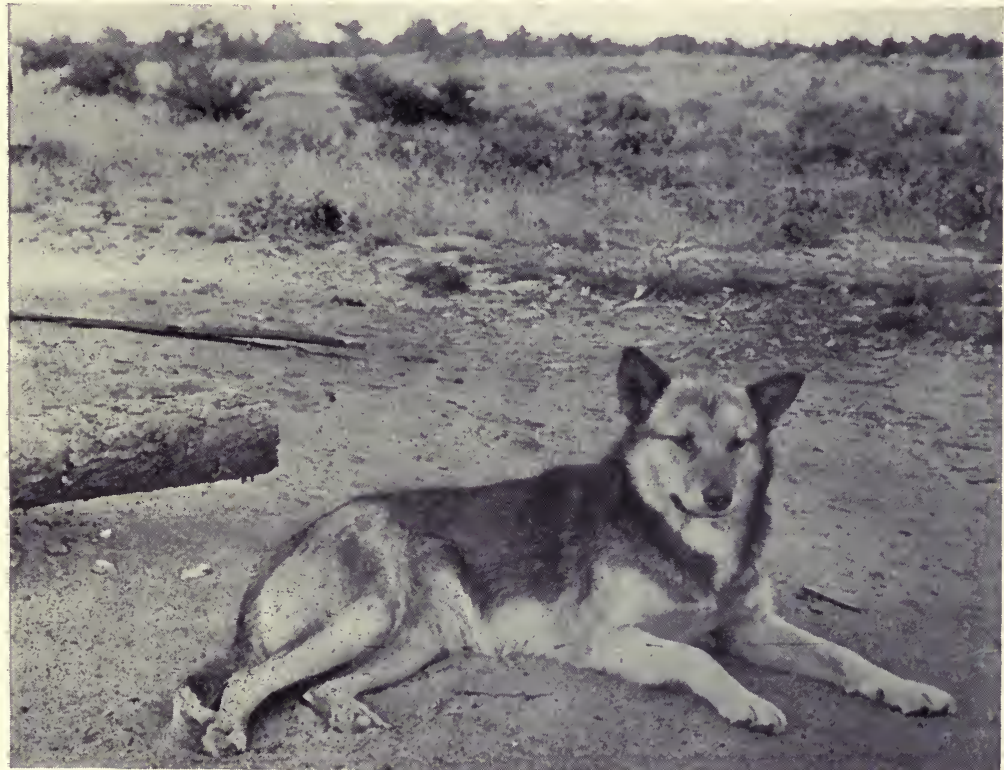

PURE HUSKY FEMALE. 

loaded sleds to Fort $\mathrm{Du}$ Brochet. Thereafter they are neither seen nor heard of until another year comes round. They bring with them pelts of White Wolves, Arctic Foxes, Bears, Wolverine, and a few Musk-ox skins-the last-named animals believed to be rare nowadays, but perhaps not so rare as it is written down to be for it inhabits, in most cases, country almost totally unknown to white men, and unapproachable. Sometimes the Eskimos bring a few Mink skins in their packs, but never Marten, which are indigenous to forested country.

But to return to the subject of sled-dogs; there are eight cabins at Fort $\mathrm{Du}$ Brochet, including the fur-traders', and the inhabitants of those owned twenty-two trains of sled-dogs: that is to say, 110 adult dogs, while a conservative estimate of pups-three to six months oldwould add some forty head to the total dog population of the Post. Remember that only records the number of dogs within that tiny settlement, for beyond, on lone lake and river, at the isolated cabins of the nomad Chipewyans of the territory, were the dog-trains of each hunting Indian-perhaps three hundred to four hundred dogs in all in that district, if one might guess a broadly approximate estimate.

And there are times, if one camps at Fort Du Brochet, when one is very forcibly reminded that there is a mighty congregation of dogs there, for, on certain nights, without visible cause, it is the custom of the whole dog tribe to point their muzzles to the moon, and in one voluble, blood-curdling chorus to break in on 
the unbounded silence of the northern night with their wolf-like, melancholy dirge-longdrawn-out howlings, oue ...... worw ... wow. . . wow. . . oue. ........... Abruptly as the dogs commence, so is the wild call hushed, after giving but a minute's utterance to the wild sad spirit that has been handed down to them by nameless forefathers from generation to generation. Particularly on stormy nights do those strange animals show restlessness and their desire to voice their wolf-howl to the whole world.

They howl also in this same deep, melancholy way when a permanent camp is broken up and their masters embark in canoes for fresh huntinggrounds. Then they will sit and howl their very souls out before they bid good-bye to their old haunts and follow the canoes along shore. It may be that they howl in dread of the unknown journey before them, or with wish to send their dog-message of departure through shadowy forest that holds the secrets of many wanderings and of many wild things. Be that as it may, in due course they depart, and commence the hard task of following the canoes, for to keep in touch they must at time swim from point to point of deep bays, and cross wide rivers, and in a day fall far behind in surmounting the difficulties in their path. At night they may overtake their masters. But only the robust and hardy dogs get through with the canoes, for the weaklings fall out and are lost, and may only reach camp in a starved condition a week or two after the others if they have been persistent and intelligent in following the trail of their fellows. 


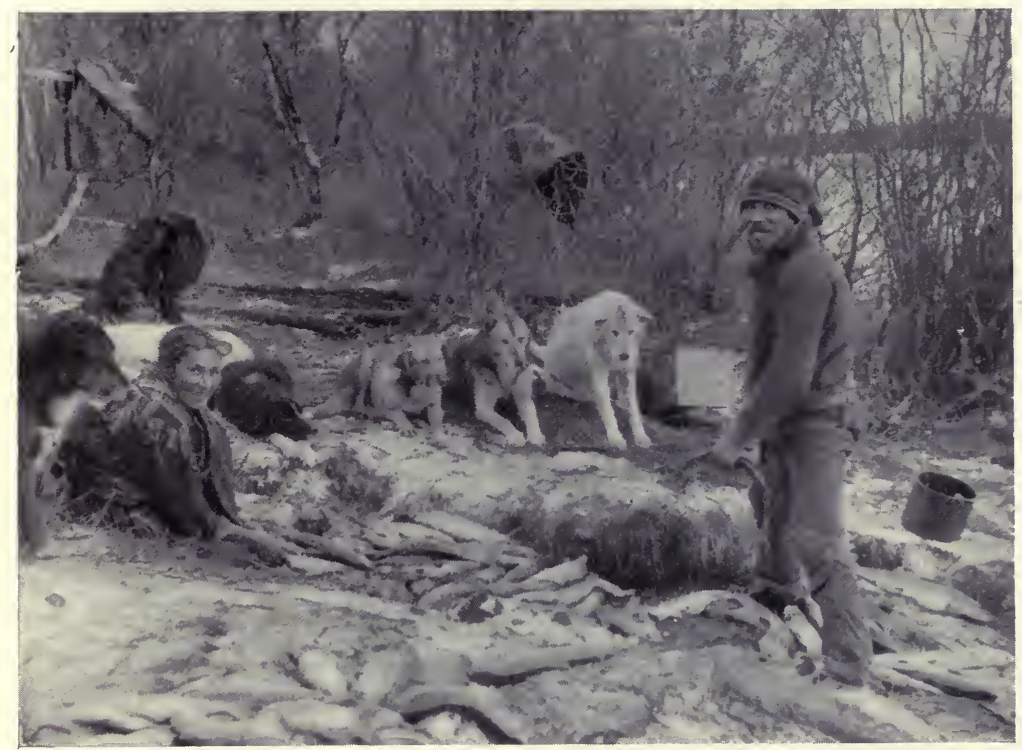

EXPECTANT, EVER-HUNGRY DOGS.

Harvesting fish for the winter in the late Fall.

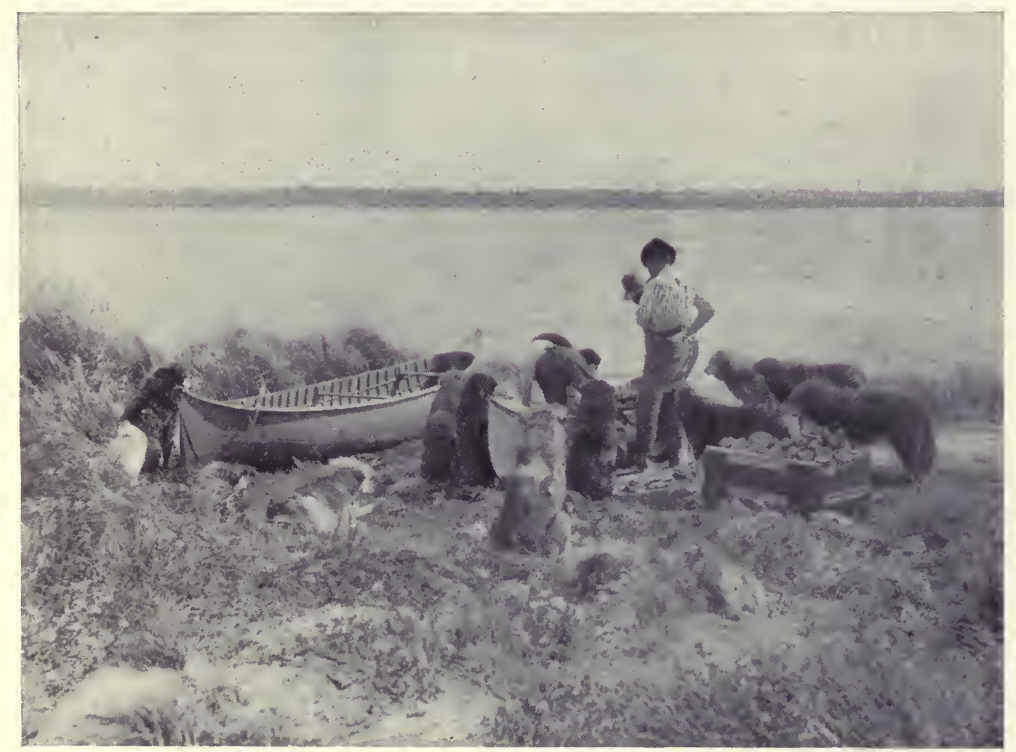

DOGS INTERESTED IN THE MORNING CATCH OF FISH. 

It will have been gathered that all sled-dogs are idlers in summer; many but little cared for, since the caring means work; others are more fortunate who have masters who consider them their property summer and winter.

Every summer day, except when storms of wind prevent them, canoes go out to fishinggrounds from Fort Du Brochet to lift their gillnets and bring in fish for human food and dogfood. And every day the keen eyes of many eager dogs watch from the shore-front for the return of the canoes, which they welcome at the water's edge, in a body-much in the manner that hand-fed colts cluster to their grain-trough at feeding hour. If the catch allows it, each dog gets one fish per day in summer-Whitefish, Jackfish (Pike), or Trout, weighing $2 \frac{1}{2}$ lbs. upwards. Down by the water's edge, when a canoe runs ashore, there are gathered other dogs besides those belonging to the two fishermen at the moment landing. Therefore, when they are ready to feed the dogs, one Indian steps ashore armed with a stout stick or pole and stands among them to preserve order, and guard against the interlopers, while the other calls the name of a dog in deep tones as he tosses a fish from the canoe into the air toward the dog he has selected, which dog adroitly catches the fish in the air, rounds his shoulders protectingly over it, and commences to tear it to pieces while holding it between sharp-clawed fore-paws. Thus the fish are distributed to the rightful dogs. There is seldom any mad rush; both dogs and men know their business. The fish, once dealt out, are 
devoured in ravenous, hasty gulps, while the strange dogs pounce in now and again to try and steal from the rightful owners, the while emitting fierce snarls and teeth-gnashings with thought to overawe the one assailed. But the Indians watch with their poles, and lay about them whenever a row arises; and growls and sounds of fierce battle are immediately succeeded by the sharp yelp of a beaten dog-then peace. Sometimes a dog carries his fish into shallow water away from the others and tears it asunder with head under water; finally seeking below the surface to be quite assured that no bits have been overlooked. In barely a minute the repast is over, so powerful are the wolf-jaws of those animals, so great their ravenous haste to devour their prey.

Everywhere in the North native laws of man and beast are stern, even merciless; the outcome, perhaps, of living half the year face to face with the powerful elements of winter, eternally fighting for an existence within the zone of the greatest counterforces of life to be met with in the whole wide world. Thus it appears, at first sight, brutal to a stranger to witness the Indians punish their dogs on the slightest provocation, and it is brutal in a delicate sense, but not so in the mind of Indian or dog, for both are of a vigorous outdoor world, and of primitive hardihood. Indians have full experience of sled-dogs. They are masters of the situation; were their dogs allowed to run unchecked all summer, or be humoured by pampering kindness, they would be useless as sled-dogs when the snows came. Hard blows teach them always to respect the 
power of man, and to stand back at a respectful distance and in due humility.

Regarding dog punishment, I have only once witnessed a squaw severely deal with one of those provoking animals. Her men-folk were away hunting, and her peculiar method was to tie the culprit to an alder bush and belabour him mercilessly with a heavy pole until one thought that if she did not cease speedily the dog would be beaten to death. He had stolen something, poor hungry, wolf-natured brute-and he would steal next hour, I wager, if the chance arose, licking or no-only with a little more caution, a little added resolve that his cunning would outwit his masters.

At freeze-up I have seen young dogs that have never before been caught and harnessed prove so savage when handled that they could not be put in the traces until stunned with a blow on the head. For two or three days such dogs are unmanageable, but in the end they become tractable and often prove splendid, hard-working, high-spirited beasts of burden.

You will have gathered from these remarks that the sled-dog is for ever in the foreground at the Far North fur Posts-numerous beyond all other things-and that is true of them.

I will deal in detail with the foods on which sled-dogs are fed, and then take you to the sled and the snowfield; that which is their purpose of existence, and where their endurance and courage overcome the bleakest wastes in all God's Universe.

What food the natives subsist on is also the food of their dogs. The year round the native 
and dog community of Fort Du Brochet, and of many Far North Posts, live almost exclusively on fish with the addition, in winter, of what deer-meat the Caribou migrations provide. Raw fish, fresh from the water in summer, or frozen in winter, is the chief dog-food the year round, and on this they thrive. And, in this respect, it is certain that the fish on which the dogs of the outermost Posts are fed has played an important part in retaining, perhaps even developing, the fine physique which the breed obtain along the trails of the Hinderland, for the fish from the pure cold waters of northern lakes are of surpassing excellence. The dogs themselves, when occasion occurs, show discriminating taste, and marked preference for their home fish, for, in the winter, should any dog-team go south to the Posts of the Frontier it is noticeable that while being fed on fish from inferior waters they will eat without relish and with an air of distaste, and deteriorate in weight and strength.

Sled-dogs as a rule will eat any of the varieties of fish that are caught in the North-Whitefish, Trout, Jackfish (Pike and Pickerel), Black and Red Suckers, and Dory-but when not ravenously hungry, and the opportunity offers, they will show a nicety of taste, and their preference, by I selecting the Whitefish, which is the choicest to the human palate also.

In a country where food is the one great problem of existence, providing for the sled-dog is no small matter, particularly in winter. Therefore on the eve of the great freeze-up, with purpose to store a large supply of fish for winter dog- 


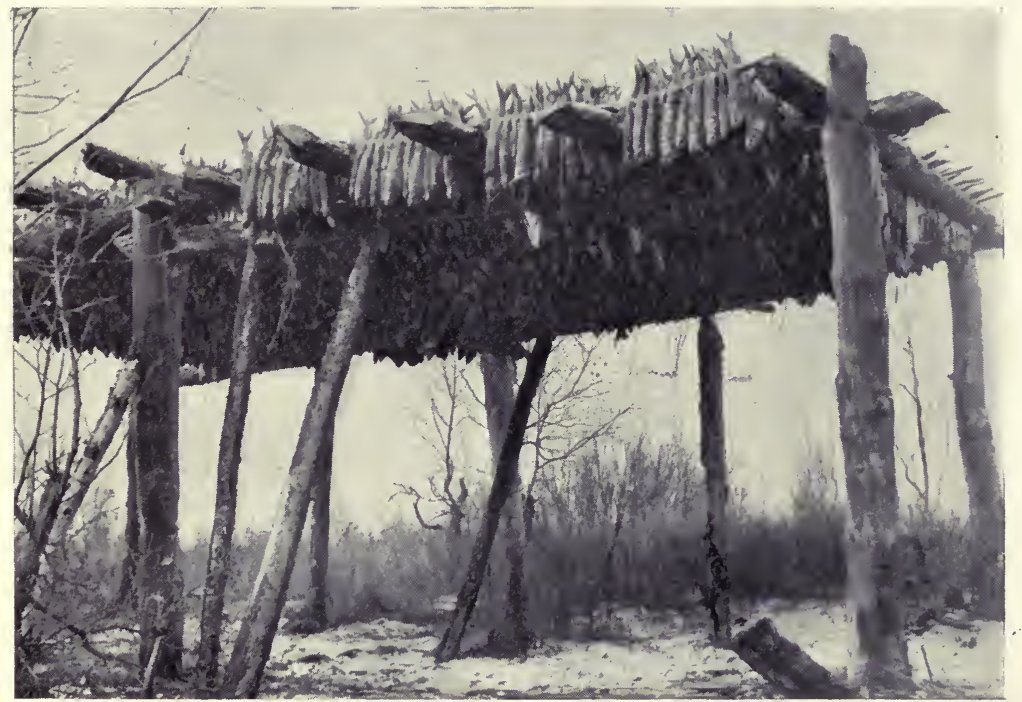

TIMBER STAGE ON WHICH IS HUNG THE AUTUMN CATCH OF FISH FOR DOG-FOOD.

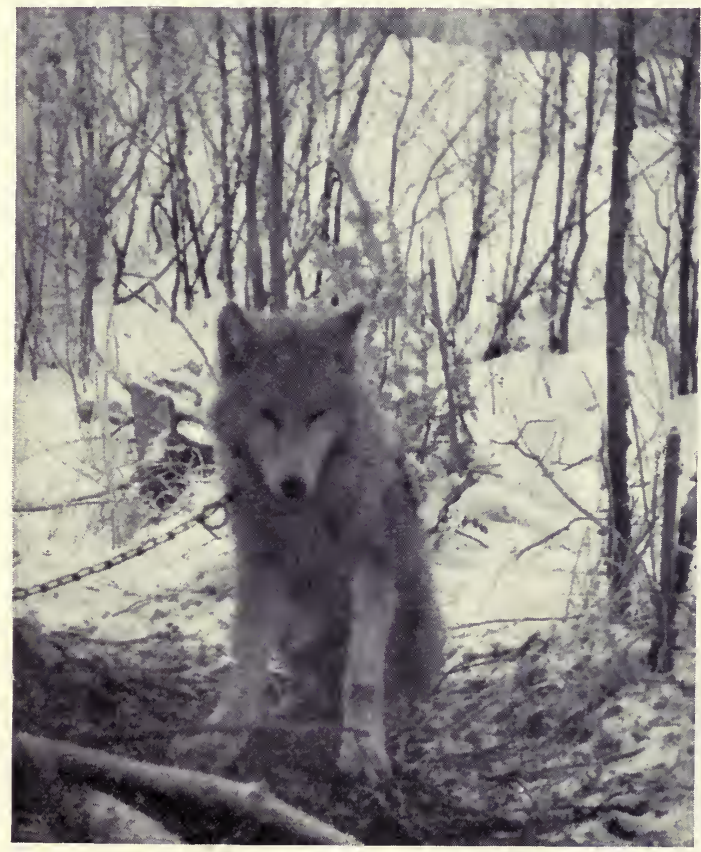

PURE TIMBER WOLF FEMALE: IN CAPTIVITY, TO IMPROVE BREED OF SLED-DOGS. $162]$ 

feed, Fall fishing on an extensive scale is yearly undertaken by the Indians. When the weather turns cold in late September or early October, all the Indians of a permanent camp depart to their well-known fishing-grounds-women, children, dogs, teepee-covers, cooking-dishes are bundled into canoes by their menfolk, and all set out for the various river outlets, where fish at that season congregate in their quest of spawning grounds. Each Indian will set from three to four long gill-nets (usually 200 feet $\times 4$ feet, with 2-inch mesh-manufactured, not native made), and those he visits once a day in the cold grey autumn dawn before wind rises; and as a rule he brings in between one hundred and two hundred fish. When landed the Indians and their squaws slit the fish through the body some little distance from the tail, and truss them in tens on green willow-rods of about two feet length. They are placed in groups of ten so that one stick conveniently allots a day's rations to a five-dog train - the usual number driven in northern territory. Large stages constructed with the trunks of trees are erected, and across the stalwart framework, from side to side, poles are spaced overhead to form racks that receive the short rods of trussed fish, which then hang suspended, head-downwards, well. out of reach of dogs or wild animals. Here the fish are frozen-sometimes completely, sometimes partially, depending on weather; and keep, on the whole, almost completely fresh until the hour the thermometer drops to zero and the great freeze-up sets in.

When heavy snow has fallen, and sleds are out, 
the frozen fish are transported from the stages at the fishing-ground, and stored at the Indians' cabins.

The total fish caught in this way varies. If a complete freeze-up does not set in over-rapidly, one man may have 8,000 , another 4,500 , another 3,000 - which is sometimes governed by the number of dogs to feed, and sometimes by the ability and energy of the fisherman. Also there is good luck and bad luck.

The following are some carefully kept, strange old records of the autumn fish-catch at a Far North Post in 1880-almost forty years ago!

Fish-catch :

$$
\begin{aligned}
& \text { Nov. } 2 \text {. } 833 \\
& 3.515 \\
& \text { 4. } \quad 507 \text { Caught with six nets to each man-four } \\
& 5-501 \text { men fishing. Twenty-four nets in all. }{ }^{1} \\
& 6.500 \\
& 8 \cdot 829 \\
& \text { Total . } . \overline{3,685}
\end{aligned}
$$

Nov. 2-Heavy snow fall; weather mild, ice still weak.

Fish-catch :

$$
\begin{aligned}
& \text { Nov. } 9 . \quad 480 \\
& 10.600 \\
& 470 \\
& 780 \text { Caught with eight nets to each man, } \\
& .634 \\
& 980 \\
& 660 \\
& 434 \\
& 438 \\
& 606 \\
& 496 \\
& 23 \text {. } 250 \\
& 194 \\
& 25 \text {. } 200 \\
& \text { Total . } . \overline{7,222}
\end{aligned}
$$

four men fishing, thirty-two nets in all. Nov.23, Whitefish, finished spawning and leaving river. Nov. 25, took nets from river and set at usual winter fishing-ground. Fishing in river never failed so early before.

1 Half the total number of nets are set each day. Meanwhile the other half - that have been lifted with the fish-are being disentangled and dried and prepared for resetting the following day. 
Nov. 11, 1880-Ten above zero, north wind.

Nov. 13, 1880-Ten below zero, waiting news of Caribou.

Nov. 14, 1880-Strong gale from west, and thawing all day, fow drops of rain-a wonderful occurrence. Next day four below zero.

Nov. 19, 1880-First real bitter weather this Fall. Twenty-nine below zero.

Fish-catch :

Nov. 27

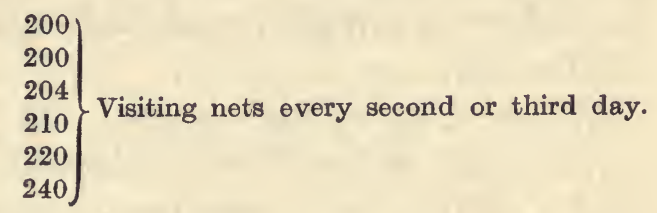

Total

$.1,274$

Dec. 13-All nets lifted-no more fishing. Total catch, 12,181 fish.

\section{Trailing over Ice and SNow}

It was a starlit morning, about an hour from daybreak, and cold as the very devil. I had got my five dogs into their harness in the awkward, persevering fashion of a man with numbed, halffrozen hands working amongst frozen collars and traces in the biting cold, while circulation is yet asleep. And now my team whimpered to be off on the trail, while they shivered and looked miserably cowed with cold.

But there was a hitch this morning, one sled was not ready to start. Mistewgoso was groping about the tree-bottoms and bushes of the forest, trying to uncover a lost dog that was buried and hidden in the snow and not inclined to turn out, being, no doubt, overtired with the hard travelling of the past few days and comfortable where he was. The Indian had circled closely around camp without success, then set out upon a wider circle, and that unavailing he tried still another, calling Natcheleaze-the dog's name-ingreatimpatience, 
and voicing the while his disapproval of the dog's conduct. Suddenly a yelp-Mistewgoso had unsnowed the culprit! Fully one hundred yards from camp the Indian's hawk-eyes had detected the dog, though he had had to search so widely to find its snow-lair, and had not overlooked it in the dark.

'We were now ready to go. The dogs stood or. lay, one before the other, in their harness - harness made up of long, continuous side-traces connected to saddle, and belly-band around their middles, and to head-collars which rested on the foreshoulders and received each dog's pulling weight. But, having been left standing, of course some of the dogs had got mixed up in their harness : they invariably do, as that is accomplished by merely turning round or getting a leg or two over the traces. Some mix-ups can be righted in a second; others take minutes and the undoing of many buckles or thongs. However, traces were soon straightened out this morning, while impatient dogs gave voice to their wolfhowls in eagerness to start. Then each driver called out to the leaders and we were off, while it was " Mush, Toyfayr! Mush, Corni! Tuok! Tuok! Tuok!...Ge-kook! Ge-kook!" (to incite them to break into a gallop and warm up). Then, "Ah! .. Peesu!" in reproachful tones, as you note the traces of that particular dog slacken, and how he is not pulling his share. Again, when it is desired to change your direction, the cry is " $\mathrm{Hu}$, Corni (leader), $\mathrm{Hu}$ !" if the lead-dog is wanted to turn to the right, or "Chac, Corni, Chac!" if to the left. 
There were three dog-trains on the trail, for two Indians were with me-Mistewgoso and J'Pierre. We had been out a week, and were still heading north.

North, always north, even against the stirring warnings of the voices of the vast unknown, and the threatened overpowering grip of the giant elements of heartless Arctic cold. At times it seemed preposterous that against those forces such little things as we, mere dust-specks in such mighty company, should dare to go on, and go on.

Ah! there is power in the North, an almost overwhelming strength of surroundings. You know you are up against it; within you you are almost sure it will get you in the end, if you go just a little too far, or are contemptuous for an hour of its antagonism.

On this occasion we were travelling far and travelling fast. Those long, speedy-looking sleds, running lightly on the surface, contained but a few "sticks" of fish for dog-feed, our rifles, axes, snow-shoes, cook-cans, and deerskin sleepingbags. We carried no freight, though, if necessary, the sleds could be loaded up to $100 \mathrm{lbs}$. per dog.

Light-fashioned those sleds looked; narrow, flat-boarded things with curling, upturned prows, rear upright back-rest, rope side-rails from back to front, and thereto attached the coffin-like body of tough parchment skins which were laced up the sides and across the bottom. But into such sleds an astonishing load can be packed. When fully loaded the bundles of freight are piled to a height of two feet or thereby, particular care being 
taken to have the whole well balanced over the sled-boards; then all are laced into final position with vice-tight ropings to prevent the load from slipping when the sleds slew at turnings, or jar as the dogs lead overland, between lakes, and the sleds dip into hollows, and over hillocks and fallen tree trunks.

In weather we were fortunate, for there had been no deep snowfall recently, and the powdery snow had drifted and packed and the surface on land or lake was everywhere firm. Snowshoes had been discarded. No trail required breaking. Overland between lakes (for it was altogether a country of alternating lake and land) we sped, light-footed in our duffel-lined moccasins behind ever-nimble dogs, alert to keep the sled-head from being dashed against upright stumps or dead logs that lay in our path

The hardest sled-driving is when passing overland: guide-rope in hand, at one time urging the dogs uphill, at another time righting the sled if a bad canting slope, or a hidden stump, has overturned it. Then, perhaps, a mad scramble downhill, guiding the sled, sometimes with somewhat random effort, as it sways from side to side in its impetuous movement, buffered off the shallow banks which it encounters on the margins of the trail. Finally, at sight of a lake ahead, the dogs break into a gallop at prospect of getting on to the level again, and the line of sleds debouch on to the lake from the forest like a veritable cataract. Breathless, or if not breathless, perspiring, we run alongside our sleds, board the protruding ledge at the rear, and step over into 
the body to settle down for a rest while still watching the dogs and urging them on. But before long we are out on the ice again, trotting patiently behind the dogs, encouraging them, and using the whip on any caught slacking (if not foot-sore, and slacking with a cause), glad of exercise to keep up warmth against the cutting cold wind we faced, and that swept over lake ice with the freedom of wind on the sea.

Travelling light, and on packed snow, with no trail to break, neither hunting en route nor trapping, it was estimated that the dogs were travelling from four to five miles an hour. 'We were travelling in three stages each day: that is, we halted to make two "fires" between morning start and night camp. In each stage the dogs ran between two and a half hours and three hours. Therefore the minimum distance of travel per day was thirty miles, and the maximum forty-five miles.

"When it was time to make "first fire," a well timbered, sheltered place was selected and the dogs run in to the lake edge. Straightway a few spruce trees were felled on to the lake ice, their branches lobbed off and spread mat-fashion on the snow to accomodate the dogs, whereupon the teams, still harnessed to their sleds, were led on to those "carpets" to there lie down, panting and tired, to cool off while their feet and bodies were safeguarded from contact with ice and snow. Back a little way in the shelter of the woods we then kindled a camp-fire, filled the cans with water from a hole cut with an axe through two feet of lake ice, and soon each one of us was enjoy- 
ing fragrant hot tea and pemmican, or lumps of cold Caribou meat saved from the previous night's cooking. Afterwards pipes and laughter while we stood, first back, then front, basking in the luxurious warmth of the log-fire.

The time of making "fires" of course varies. There is really no mechanical measurement of Time in the Far North; only are the spans of daylight measured by the sun, or by unfailing instinct if there is no sun. However, a fair guide to halts on the winter trail are: Morning Fire, 6.30 a.m. (about an hour and a half before daylight); First Fire Halt, 9.30 a.m.-10 a.m.; Second Fire Halt, 2 p.m. -2.30 p.m. Night Camp, 5.30 p.m. (about an hour and a half after dark). It is on account of those customary halts that Indians always answer questions as to how long a journey will take by giving you the number of times they sleep or make fire. Thus they say : "To go Eskimo camp, we sleep ten times" (twelve days' travel); or again, "To go Gullfoot's wigwam, we make two small fires" (about six hours' travel); or "two long fires" would mean about nine hours' travel.

Throughout the day we kept trailing into the North over river and lake and land that ever changed in line and aspect yet never lost the dead white countenance of frigid snow. The "first fire" we left behind, and the second, as we had done on the days before-each marking so much gained on the scale of man's ambition to explore, yet piling up the leagues of snow that lay behind, lengthening the gulf between solitude and the voices of fellow-mankind. 
Even after the short winter's day had ended we were still calling to the dogs and urging them onward as they flagged at the end of a hard day's work. The wind had dropped, it was some degrees more intensely cold, and, outside our small activities, the whole vast land was deadly still with silentness. On, ever on, like a shaft of black shadow, the line of sleds crept toward the head of the large lake we were crossing, until our moving forms were brushed from the level white surface and engulfed in the darkness of the dwarf forest on shore.

Among the trees we made camp. The sleds were drawn into position to barricade our sleeping ground against the dogs and the cold; and then the dogs were released from their harness. Boughs were cut and laid for the dogs to rest on, and then all hands turned toward making the night's camp. Space was cleared sufficient to accommodate a large log-fire and our outstretched forms. The fire was kindled at the edge of the space down-wind; up-wind, the full length of our bodies from the fire, the back of a two to three foot barricade was built, while similar sides enclosed our camping space to the fire, which counted the fourth side of our enclosure. This threesided barricade before the fire was partly formed with sleds, and completed with felled trees and snow-banking.

As soon as the fire was well ablaze the "sticks" of fish were ranged before it to partially thaw out before being fed to the dogs. While this was being done the camp was laid with a thick mattress of boughs so that we would not sleep 
directly on the snow. Also a great pile of dead timber was gathered for the night fire.

Those things were completed and the dogs fed ( $t w o$ fish each) before any attention was given to our own wants. Thereafter pots of meat were boiled over the blazing fire, and tea, and we ate with the deep content of lean and hungry men.

In time the camp was ready to sleep. Beyond the fire glare most of the dogs had ceased to move and had dug themselves holes beneath the snow. Mistewgoso made a final round outside the barricade to make sure the sleds were thoroughly protected from ravaging dogs-some of whom would prowl stealthily round camp like wolves after we slept-then, when he returned satisfied, clad as we were in our heavy fur clothes, we curled into our fur-lined sleeping-bags-feet to fire, and sheltered by the barricade from wind-and forgot the cold and the trail in dreamless sleep.

I have endeavoured to describe a day on the north trail, particularly the mode of travel. I have known many such days-their food-shortage: no Caribou : dogs weakening, dogs footsore, dogs dying : and Indian companions losing faith. Travelling north is not free of risk at any time, it is far from pleasant then. But when without food in bitter weather those dogs of endurance will gamely do their best for three or four days and may save an anxious situation in the end. It is then that one learns the greatness of their strength, and the spirit that resists to the last blood-drop, unmurmuring, Big as the sterndisciplined North that has mothered them. 


\section{CHAPTER VIII}

THE TRAPPER

DAY was breaking, and cold mist, less white than the virgin snow, hung over the land; slowly it was lifting now that the long winter night was over.

Gullfoot came to the door of his cabin, fumbled a moment to release the wooden peg-latch, coughed heavily, and looked out in grave contemplation of the dreary scene while chill air searched like deadly serpent in through the open door. The clearing, the great expanse of frozen lake to North and South, the dark forest background: all were familiar and dear to his heart. But to-day he saw them not in appreciation, for his thoughts were with the weather and its overnight effect on his long trap-line.

A little fresh snow had fallen; enough to spoil Fox-traps on the lakes if wind should arise and drift it: but, wind or not, other traps, set in the shelter of the forest for Marten, and Mink, and Wolverine were safe from being smothered, and the better disguised from human scent, now that they lay beneath this light, fresh covering of snow. . . . Hud! there was no need for anxiety this day: traps were not buried in two or three feet of fresh snow; and there was no indication of storm. 
Gullfoot did not stand long at the door : a moment was enough to idle there in zero weather when warmth was within; and enough time, too, for him to read the weather and make deductions. But even in those moments in the morning air that racking lung cough of his broke out again and shook the very foundation of his frame as he closed the door behind him. Alas! it was often so with him in those bleak winter mornings, for this strong, athletic figure of a man, whom you might think could not know sickness, was touched with the Indian plague and had in him the seeds of consumption, though no hectic flush could ever mantle his copper-bronzed face to betray in that its presence.

Gullfoot's winter cabin was of logs, built with care with the stunted scrub pine of the surrounding country. It was a small low building of sturdy appearance; the four corners were notched together with the accurate skill of a practised axeman; the walls were straight, and grey as stone with the clay-mud which filled the cracks between the timbers; the roof, which was thickly thatched with marshhay, pitched steeply and threw deep shadows at the eaves-a simple, primitive dwelling, but true to its purpose to withstand the rigour of Arctic winter and afford full shelter for its inmates.

Indoors there was warmth and comfort, and pleasant scene of native homeliness. The low room, to which Gullfoot returned from his survey at the door, was dimly lit from a single small window opening in the south wall, across which was stretched a sheet of clear skin parchment 
to serve as "glass." The walls were ornamented with beadwork, some old bows and arrows, a powder-horn, and a muzzle-loading, leadball, flint-lock rifle hung from wooden pegs in rare disorder. The bed, which nestled close to one wall, was framed with boughs from the forest and filled in across with light branches to form the "spring," while, over this, laced hay-grass furnished a mattress : the whole was abundantly covered with thick warm Caribou rugs. A crude table and three chairs occupied the centre of the floor, articles hewn smooth with axe and knife, and much labour, from the woods of the forest, and grained naturally with constant use. In the far corner a log-fire blazed brightly in a hooded, stone-built fireplace, and threw its light in dancing wavelets along the darkly smokefumed timber of the rude-cut ceiling beams. A black iron pot hung over the fire, hooked to a rod; a dwarf wooden stool was by the hearth. On the wall close to the fire, pots and pans filled a shelf close to the floor. Overhead a string of dry medicine roots and a fire-bag hung from a rafter. At the fire an Indian woman was preparing food, and, as was her habit, she but glanced up as the man came in and continued her duties without a word. Her face was set and grave as became her age, for the countless withered wrinkles told that she was in the autumn of life Hers was a shrunken face rather than full, and the skin was bronzed as with a deep sunburn. In the profile lay character, for the outline was straight and refined, and firmly chiselled with the impression of endurance and patient strength. En- 
hanced by jet-black hair and deep dark eyes there lurked still in this face the shadow of bygone comeliness and of proud native womanhood. The figure, which was clothed in black European clothing, excepting the tanned moccasined feet, was tall and erect, unbent with the weight of years, and hers was a bearing that bespoke activity unusual to one of her years, even among the tribes of her own enduring people.

Her name was Nokum, the squaw of Gullfoot.

There were no children in the cabin. Two sons and a daughter there had been, who had married and gone to hunting-grounds of their own.

Gullfoot himself was a pure Chipewyan Indian : chief of hunting people in manhood, child all his life of the waste places near to the edge of the Barren Grounds where the Eskimo is neighbour over the marches to the north. He was a handsome man even at fifty; a very handsome man. $\mathrm{He}$ had beautiful, even features throughout: a broad forehead-typical of the Chipewyan race-high cheek-bones, a finely shaped nose, a strong, square chin and a firm, clear-lipped mouth. In stature he was tall for an Indian, being not much under six feet, perfectly set up, active in every movement; lean; an athlete, every inch of him; and at times this man's bearing and reserve was that of a monarch, a man whom you instinctively felt had pride of race, and on whom you could never look as an inferior. But he was no monarch, and made no pretence to be. The days of the Great Chiefs were over, though drops of their blood remained. Gullfoot was Indian, and therefore a hunter and wanderer 
by instinct, and to know him at heart you had to look in his eyes, eyes that were dark almost to blackness yet alive with light and activity; to know him still better you had to go with him out on the trail and marvel at the skill and resource of this primitive man, while realising how far his education and intelligence were ahead of your own in reading every mood of the wilderness-the elements and the creature things-on which the welfare of white man or red wholly depend if they are to exist in his country. . . .

About noon on the previous day I had landed at Gullfoot's cabin greeted by the fierce barking of his dozen sled-dogs, whose clamour he came out to quell while welcoming me in. It was then bitterly cold-zero weather, with a strong wind blowing from the north-west. Sun-dogs, or parhelion, a bright mark of short perpendicular lines of softly hazed, luminous rainbow tints of almost similar radiance to the sun, had been showing in the morning sky on either side of the low winter sun at wide but equal intervals from it; phenomenon peculiar to the dead of winter. And it was indeed that season-the Dead of Winter : Gullfoot, the following morning, quaintly. showed me his record that it was so, in pointing to the rising sun where it struck through the window into the very corner in the north-east interior of his cabin. It was thus in his home that he measured the shortest days, and the longest days : in the height of summer, he told, "it reaches away to that axe-notch in the centre of the north wall."

Gullfoot made me welcome, and I was glad of 
the luxury of shelter of a house-roof, and to obtain food for my far-spent dogs. Do not ask me where I slept in this single-room cabin. I did not turn the good people from their couch, and I was comfortable nevertheless, and thought it considerable good fortune to be indoors.

In the meantime I had arranged that I would accompany Gullfoot on his next round on his trap-line.

He would go to-morrow, he told me on his return from his morning weather survey through the door, for he thought the wind would rise later in the day, and if so his traps on the lakes in exposed positions would require resetting. $\mathrm{He}$ had been out six days ago, to-morrow would be the seventh day, and the weather in the interval had been particularly good and promised some pelts.

So I had a day to wait at the cabin.

Gullfoot employed part of his time on the construction of a new sled-a sled with runners on either side of about a foot depth below the sled-board bottom; not the flat-bottom, runnerless sled of the type common to the Indians a few degrees further south, where larger wood for broad boards is obtainable. The runners he made were peculiar, for they had no frame, no iron "keel"; just layer after layer of wet moss laid on and frozen stiff until the runners were fully formed and shaped, when they were then axe-pared, and planed to smoothness, and iced over by applications of coatings of water. They were, on completion, veritable planks of rigid ice, with stout adhesion, and latitude for 
expansion and contraction secured by the admixture of fibrous moss. A sled so made serves well; verily " necessity is the mother of invention."

While thus working, outside the cabin door Gullfoot's dogs, and my own, prowled about; but to those he paid no visible heed. An Indian has no warm affection for animals, and Gullfoot was no exception. However, in reply to my questions, he pointed out his best team, and named them in Chipewyan-which names were in English translation Day Star, Raven, Smoke, Evil Eye, Lynx!

Those dogs were typical of an Indian's team in the north, and therefore, perhaps, worth brief description: RAven : A very big husky, larger than the common, and with longer, almost shaggy hair. He was black in colour except for a fawn mark on the eyebrow over each eye. Gullfoot used him in his team as the sled-dog-the dog next to the prow of the sled-where his weight served well to steady the slew, or buffeting, of the sled when in motion.

SMOKE : A dog of striking colour, and purity of breed. A splendid-looking husky in form; and white throughout with just a tinge of buff. He was such a dog as everyone in a city would turn to look at in admiration and wonder, did you transport him there. He was a good worker and well broken.

EvIL EyE : This unfortunate dog was blind in the right eye, which shone glassy green. Otherwise he was without blemish and a fine, powerful, active-looking dog. He was grey-wolf colour except for an old white left-shoulder mark. 
Gullfoot reports him bad to harness, being restless and excitable, and always twisting himself in the traces at a halt ; but he was a good dog otherwise.

Lynx : A little short-limbed active dog, about the size of a highland collie, with a much-scarred nose and a reputation for fighting. He was a crossbred dog with drooping ears, and was chiefly black in colour, with brown belly and paws. A dog one would not look at twice, but worth his weight in gold. "My best dog," said Gullfoot; "pulls hard, has a great heart for work, and doesn't know when to quit." He looked it : game through and through.

Day STAR: Neither a husky nor a cross-bred sled-dog ; just a mustard-yellow terrier-hound mongrel with scant, close-set coat of hair to withstand cold. She had a white star-mark on her forehead, but she was well named on a second score, for she it was who guided the team at Gullfoot's bidding. This was Gullfoot's leader; an animal of wonderful intelligence, he told me, in following snow-covered trails, and with a memory almost more acute than that of a human being for places she has once passed. Gullfoot showed his appreciation of her in covering her short-haired body with a blanket-rug to help keep her warm when on the trail ; a considerable, and rare, condescension on the part of an Indian toward a dog.

After discussing dogs, we talked foxes. Everyone in the North talked foxes in 1914. With the floating of Fox Farms in the Eastern Provinces the demand had gone up for live fox cubs of all kinds, and hunters were tremendously stimulated 
by the enormous prices given for silver or black cubs, which to the fortunate captors represented a veritable gold-mine.

In April and May, when the fox-dens are located and the cubs dug out, places such as Big River and Ile à la Crosse were "fox-crazy," and the whole territory within reach was being scoured for Reynard.

This wholesale capture of foxes serves the mood of the moment, but I fear there are yet to be many regrets when both trapper and foxmerchant come to realise that they have killed "the goose that laid the golden egg."

If wild-fox fur is to remain a valuable asset to Canada, digging out the young in the early spring should be made illegal by law, or limited by law to a very stringent degree. The export of live foxes is governed in a degree by the issue of permits, but these permits in 1914 were generously given, it seemed to me, and, moreover were often evaded; nor was it possible in out-of-the-way places to follow the movements of keen buyers or the extent of their purchases.

Again, in 1914, by a recent revision of the Game Act, it was unlawful to take foxes before May 15. This restriction was seldom observed north of the frontier, cubs were dug just when the dens contained them, and kept until they were wanted by the buyer. Such a state of affairs would cease if it was unlawful to dig out foxes and unlawful to buy foxes, except, perhaps, in a very limited degree, and only under Government supervision. Obviously, if it is desired to preserve a declining species of any kind, man- 
kind must protect it at the time it is bringing forth young. And it should be borne in mind also that many of the foxes are dug out of their dens when but a few days old, and a large percentage totally lost during early captivity, when artificially mothered and artificially fed.

Moreover, it may be doubtful if Fox Farms, the booming of which has been a means of entertaining public speculation, will have any great success beyond a temporary one. Foxes roam far, and are very restless in their wild state, and it seems idle to expect other than an inferior race from production in confinement, even though the farms succeed in increasing the number of Black and Silver Foxes, which is their object. Temperament, freedom, food and temperaturefor the further north the better the fur-all seem to point to this. Thus trapping the adult fox in its wild and natural haunts, in the few months when the fur is at its prime, is conceivably the fairest way, and the best, to encourage lasting fur trade, while, at the same time, such trapping does not reduce the stock unduly. Furthermore, trapping the fox in its native haunts worthily helps the Indians to a means of obtaining what little luxuries they have; and those of them that remain of the race of peoples whose country we have overwhelmed deserve every consideration that can be given. It would be surely a pity to take away from them a part of the trade which they have always had since their first meetings with the white man.

The fur of those foxes under discussion is that which eventually finds its way in great bales 


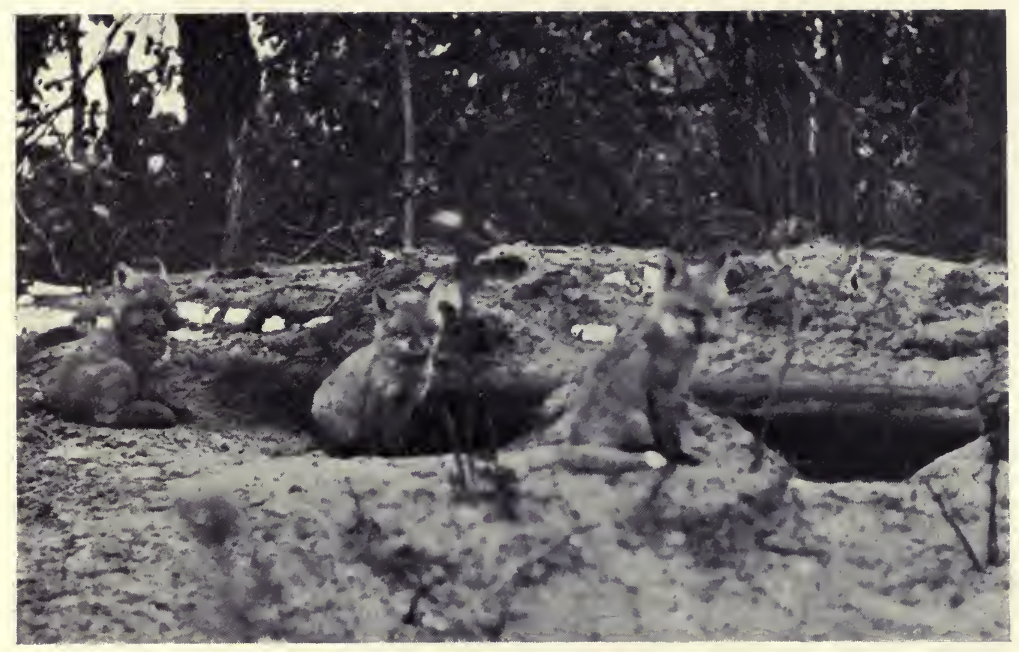

LISTENING ATTITUDES.

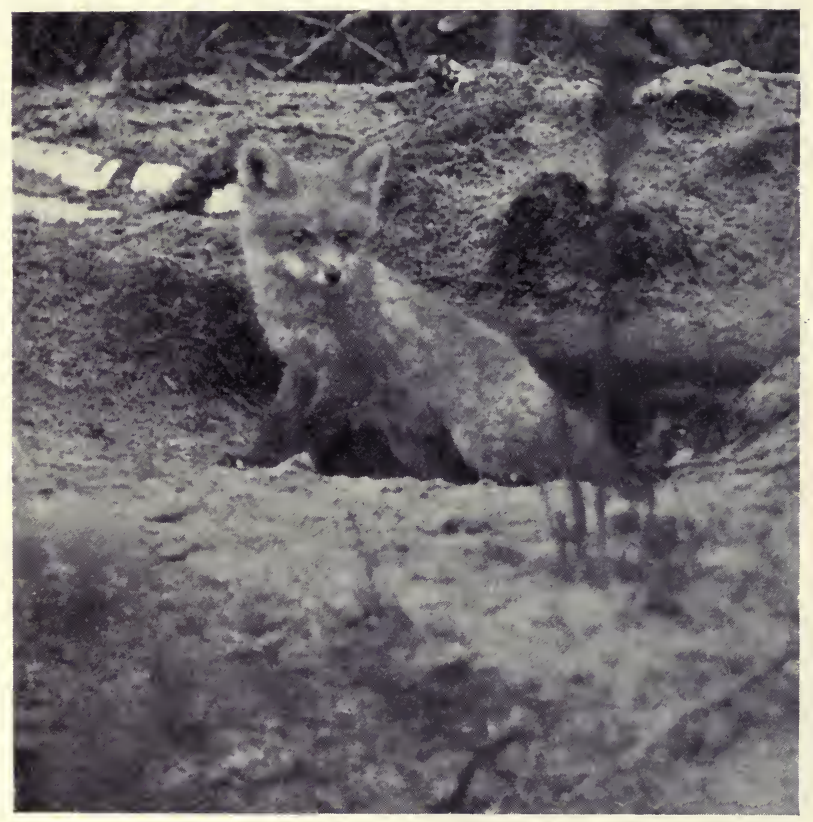

IS ALL CLEAR? 

to London and Paris and New York, to be eventually made up and marketed in costly robes. And it may be of interest to here set forth some description of their definitions in the country of their birth.

There is, as there is a wide range of colour, a wide range of values in fox fur in the raw state. A prime black fox pelt may fetch, in accordance to size, $£ 100$ to $£ 55$, and the all-silver fox $£ 30$ to £16. Between those prices are graded the threequarter-black (three-quarter-neck is the term of the traders), half-black and quarter-black, whose definition of colour $\mathrm{I}$ will describe further on. But those are the rare skins; the typical red, and ordinary Cross fox, are worth about $£ 16 s$., the good Cross about $£ 28 s$.

Pelts are bartered by the Indians for tea, sugar, tobacco, ammunition, clothes, etc., etc., though sometimes a small percentage of the transaction is in cash. All goods that pass in barter are highly priced, for the heavy cost of man-transport over the long difficult trail to the post has to be added, as also have losses en route, and various percentage margins. So that stores that might be bought for $£ 30$ at Prince Albert might be valued at say $£ 50$ at Fort Du Brochet at the end of a summer's transportation.

Dealing now with the range of colours : if one said that one Black or Silver Fox was caught in every fifty foxes trapped, one would be somewhere near the proportion of their rarity. I have arrived at such a proportion from actual figures of catches in 1913. Estimates many years ago, from one Hudson Bay district, of foxes caught 
over twelve years-from 1848 to 1860 -stated that $\frac{2}{15}$ were silver or black, and of the remainder $\frac{7}{15}$ cross, and $\frac{6}{15}$ red. $^{1}$ Since then the black and silver foxes have become more rare.

All foxes in the north of Canada, excepting the Arctic or White Fox, are of the same species, though separated in trade, on account of the varieties of colour, into four classes: Black, Silver, Cross, and Red. There are grades of shade between the pure Black Fox and the pure Red, but the above are well-defined limits to work on. Only in two places is the colour unchanging, for the tip of the brush and a small mark on the forebreast remain always white.

Regarding the actual production of the different varieties : the offspring of two Silver Foxes might be silver; on the other hand, such mating might throw back to Cross or Red ancestors. But in any event foxes, in their wild state, do not cohabit strictly in pairs. At the season of propagation a number of males accompany a female much in the manner of dogs, and fight violently for possession of her; and as those males may vary in colour, so may they give rise to the varieties which may be found in a single litter.

The perfect Black Fox is glossy jet-black throughout, excepting the small white mark on the forebreast and tail-tip, while there may be a very few silver hairs on the back over the rump.

The Silver Fox is similar to the Black Fox, but may have a greater or lesser area interposed

1 Through the Mackenzie Basin, notes on mammals by Roderick MacFarlane. 
with silver hairs, and those areas are usually designated in the Fur Posts by the terms, "threequarter-neck," "half-neck," and "quarter-neck." A three-quarter-neck Silver Fox is all black except over the rump and hindquarters, which area is lightly interspersed with silver-grey hairs; a halfneck Silver Fox is the same, except that the silver hairs extend to the middle-back; while a quarter-neck has the whole black body interspersed with silver hairs excepting the head and neck, which are all black.

The handsome Cross Fox has many variations of colour, brought about by a greater or lesser amount of greys and a corresponding variance of the extent of red. However, a typical Cross Fox has the entire back and hindquarters thickspeckled stone-grey, and the forehead and sides of head the same colour; the rear of the hindquarters and the root of the tail, underneath, show pale whitish buff; the tail is black on the upper side, excepting the white tip, and paler buffish black below; the under-jaw, throat, breast, belly, and all limbs are black; the sides behind the foreshoulders, and the neck behind the ears, are reddish buff ; the back of the neck is reddish-tinged grey with more black showing than on the back; the back of the ears is velvet black; the nose to the eyes is black with a few silver hairs.

Lastly, a typical Red Fox has a general body colour of medium yellowish-red buff, with the belly and legs and the back of the ears black. But it must be borne in mind that the Red Fox has degrees of variation from this colour leading 
out toward the most reddish-grey varieties of the Cross Fox. ....

By night Gullfoot and I had exhausted our fox-talk, which had been sustained by my interest in his collection of freshly trapped pelts, which he took some trouble to show me.

As full night came on, accompanied by inevitable increase in low temperature, and Arctic array of Northern Lights, we turned in to sleep with thoughts of an early start on the morrow.

Two hours before daybreak next morning we were astir in the cabin, and, aided by a glimmering, fitful light from a vessel containing liquid grease rendered from wolf fat, which fed a piece of twisted rag to which light had been applied, we robed in our outdoor clothing of Eskimo Caribou suits, and prepared and partook of food.

An hour before daylight, out in the bitter cold, our dogs were harnessed and ready to start.

All day we travelled on Gullfoot's trap-line through forest and over lakes and rivers. By night we must have covered some thirty to forty miles, and had visited forty traps, from which had been taken one Cross Fox, one Red Fox, one Wolf, four. Marten, and three Mink: which Gullfoot assured me was a successful and gratifying result.

From this it may be gathered that trapping is not a simple task, and animals not to be picked up in any abundance even on a wide range. Broadly speaking, Gullfoot had one trap set to every mile, and those sets resulted in one animal captured to every four miles. If one assumes that Gullfoot trapped with equal vigour during 
the best three months for fur, viz. November, December, and January, and visited his trapline every week with equal success, his total catch (thirteen weeks $\times$ ten animals) taken in a season would represent practically three animals to every mile of territory. One hundred and thirty animals, the total thus arrived at, is, however, a much larger catch than is common, and would in all probability, on an average, be much reduced by spells of bad trapping weather lasting over a week or two, and consequent less productive days than the one I write of, which was in any case, apparently, a particularly successful one. Then, too, traps are sometimes changed to fresh localities, often as far afield as three days from the trapper's cabin, which vastly increases the area covered; so that, all things considered, it may even be doubtful if one mile can produce to the trapper one furbearing animal in a season in the Far North country immediately south of the Barren Grounds.

All fur-bearing animals, whose kind have been hunted and trapped for generations, are exceedingly wary, and it is a revelation to a novice to watch an Indian gravely make his sets with superb cunning, sufficient, in some instances, to outwit the most wily of quarry.

I will endeavour to describe how Gullfoot's traps were set, which are the usual Indian methods.

His fox-traps, without exception, were always set in the open snow on the ice near some prominent shore point of an expansive lake, or near an island; or in the narrows which sometimes con- 
nect two or more lakes. He had twelve traps set in such locations, strong double-spring traps of the size known as No. 2. Those traps were chained to a pole about six feet long and of calculated weight to prevent an animal from travelling far, while at the same time it would give if severe strain was put upon it; this latter to prevent the fox from obtaining sufficient direct purchase on the trap in endeavour to break its foot clear when caught. When a favourable spot had been chosen, the log was carefully buried beneath the surface of the snow, and the trap set, with a fine sheet of tissue paper-carried for the purpose, and obtained at the Fur Postlaid over the pan and jaws to prevent snow filling below, where it would choke the drop, and the whole then covered with a light powdering of snow until every sign of human disturbance was erased. A few morsels of meat or frozen fish were then spread near, but not necessarily directly at, the trap, for it often allays suspicion of a trap's actual presence to allow the animal to find food in safety during its first timid approach, when it naturally then becomes more bold. The situation of the trap was usually near the top of a small mound of snow, natural, or made up with snow, and somewhat resembling a buried stone, for it is known that foxes are prone to investigate such objects, probably in the hope that it is a snowed-over carcass of some kind, or retains the scent of a comrade who has passed before.

Twice Gullfoot's fox-traps were set in the neighbourhood of a Caribou carcass, and one of 
the foxes taken was there caught. In those cases the traps were not set at the carcass, but some distance away, where the foxes would circle suspiciously before daring to approach this quarry.

Traps for Marten were set in the forest at the foot of dark spruce and pine trees. Gullfoot's method was to make there a tiny enclosure which in plan was like a U lying on its side, the bottom of the $U$ being the tree trunk, and two little palisades forming the sides made with closely set upright stakes stuck into the snow. As in the top of a $U$, there then remained an opening : and there the trap-a single-spring No. 0-was set just within the entrance, while beyond the trap, inside, next the tree trunk, was placed a fish head pegged down with a stick: to reach this bait any animal desiring it must pass over the trap. Over the top of the palisade; to shelter the trap from snow, and the bait from the eyes of the thieving Canada Jay, a number of spruce boughs were laid, and covered with snow to resemble the surroundings. Footprints were then carefully obliterated for some distance as we retraced our steps, and the set was then complete.

Mink-traps were often set in much the same manner, but in very different surroundings; the chosen situations being about the overhanging banks of narrows between lakes, or of frozen streams, for those animals frequent the neighbourhood of water. In some cases Mink-traps were set in naturally formed narrow runways at the bottom of a bank, along which a small animal was almost sure to pass if it came that way. Such sets were unbaited. 
At one point in the forest Gullfoot had a cache of Caribou meat, and below this he had set two powerful traps on the chance of the store attracting a Wolverine. The cache was constructed with three triangularly placed upright poles of length a little more than man-height; the tops of those uprights carried horizontal poles, which formed a V, and across this was laid a platform of branches, upon which the frozen meat was stored. The three upright poles were dressed free of bark, and thus smoothed to prevent Wolverine from securing claw-hold, if any should endeavour to climb to the platform overhead; and there, on the snow below the cache, the traps were placed, so as to ensnare any such thief at his foul work-two traps required to hold this gluttonous animal, which has a tremendous reputation among the Indians for strength and capacity to break free after being caught.

By late afternoon we had reached the far end of Gullfoot's trap-line, and there encamped for a few hours to rest the dogs before resuming on our way back to the cabin on a wide détour so as not to further disturb the neighbourhood.

About 6 p.m. we started back through the bleak silent land of snow, lit on the way by the whiteness underfoot and a clear sky overhead, sparkling, in the crystal-clear atmosphere, with more stars than one will see anywhere else in the world, unless it be at the North Pole. Gullfoot and his dogs leading, with unerring intuition finding their way through this land of awful greatness and sameness without apparent trouble, as I might at home travel a road familiar to me. 
At midnight we reached his cabin.

There was Nokum sitting by the fire, and the pot, filled with Caribou meat, simmering slowly, awaiting our return.

Frozen sticks of fish were brought in from outside, and set before the blaze to thaw out for food for the tired dogs ... the teams were unharnessed and fed .... and their snarling ceased while we gathered indoors to our wellearned repast and repose. 


\section{CHAPTER IX}

\section{LEAVING THE LONE LAND}

"The winter! the brightness that blinds you, The white land locked tight as a drum, The cold fear that follows and finds you, The silence that bludgeons you dumb. The snows that are older than history, The woods where the weird shadows slant; The Stillness, the moonlight, the mysteryI've bade 'em good-bye-but I can't."

Robert W. Servioe. ${ }^{1}$

IT was with many such feelings that I turned finally into the South to depart from the strange North land that was so desperately stern in its character of wild overwhelming vastness and rigour of elements, although forever alluringly attractive withal.

Unsettled in my ambition to go on by the news of my country involved in war-which had, perchance, come to me through a trapper about a month before-and by food problems confronting me at the edge of the Barren Groundswhich would take months, if not longer, to overcome-I had, on November 29, when I and my two Indian companions were out of food and losing our dogs and our courage, turned at the edge of the Barren Grounds, and regretfully abandoned the fond hope that I had enter-

1 In The Songs of a Sour-Dough, by Robert W. Service. 


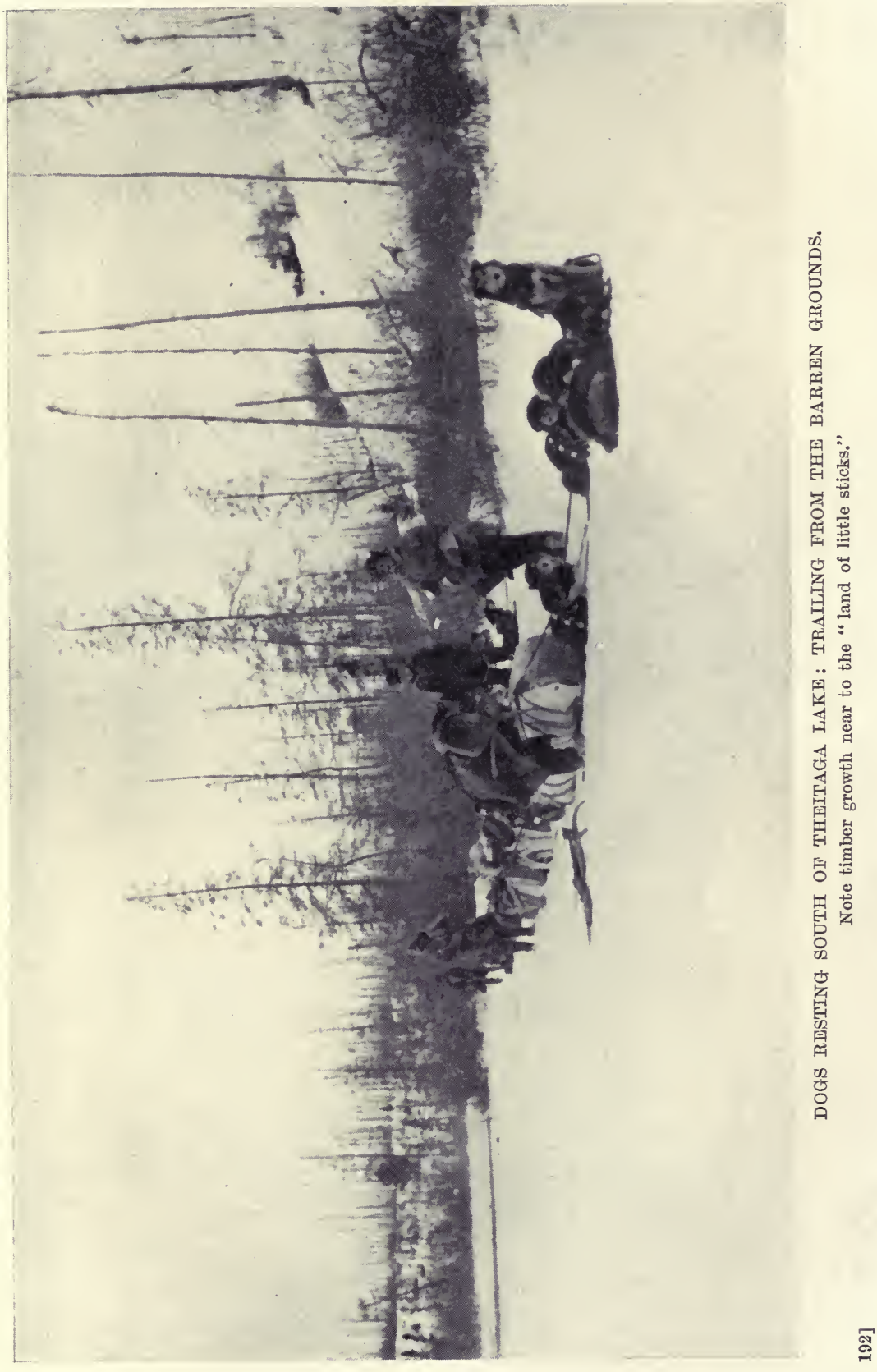



tained of spending the following summer right over on the Arctic coast.

Two entries in my diary at this date refer to the condition of my dogs :

"November 28. - Snowstorm all day drifting wickedly on a strong east-wind blizzard. Onward throughout the day, crouching like distressed animals, we fought our way ahead over shelterless lakes. Peesu, one of my dogs, will not eat to-night, so utterly done-up is the poor brute. He lies in his lair in the snow, unwilling even to raise his head. I finally coaxed him to swallow a few tit-bits of dried meat ere turning in to sleep.

"November 30.-Off on the trail at daylight. Meadowsteuce-my lead-dog-dying, and had to be destroyed before leaving. Peesu somewhat recovered, but he, and Musquaw, and Whisky are all lame. I have but one sound dog. Travelling in yesterday's blizzard was too much for them. Some of the Indians' dogs are exhausted also."

I fancy no one cares to give up and admit a total, or certain amount of, defeat in the midst of furthering a big enterprise ; it is indeed heartbreaking to do so: and yet one can be so overwhelmed by circumstances that it becomes foolish to go on, and wise to bow to the grim hand of Fate.

Though there were difficulties lying before me on the foodless, snow-covered wastes of the Barren Grounds, these were possible to surmount in time, but I could in no way, in this land where 
one has plenty of opportunity to think, and where one's thoughts are prone to probe one's conscience, justify the continuance of a personal ambition while I knew my country had need for my service, and kinsfolk expected my homecoming to rally to the Flag.

Therefore, abandoning further-north travel as I have said, I returned reluctantly to my basecabin north of Fort $\mathrm{Du}$ Brochet and stayed in that neighbourhood until Christmas in the forlorn hope that the yearly Christmas packet, due from the south at that date, might contain some more favourable news of the War; hoping even that the astonishing storm of arms which had so quickly risen, had as quickly subsided-perhaps even ceased.

Vain, unnoticed hope!-doomed to be utterly wrecked as wave upon wave grew upon the rising tide of warfare, and engulfed every other thought or desire; its vast upheaval searching even to the far-distant doorstep of my log-cabin to find therein a victim.

Christmas came, but with it no packet; strange, unheard of delinquency that bore gravity to the hearts of the trader and the mission priest at the Fort. "There must be something seriously wrong," they thought, and, most dreadful thought of all, "Could war possibly be going ill with our country?"

We gathered in grave consultation hour after hour, and our one topic was war ; trapping, furtrading, religion, had ruthlessly gone by the board. Hours were spent in conjecture; ideas constructed from our slim store of early war 
news; hopes and forebodings voiced of sheer imagination; but from all it was not in our power to raise one single conviction of comforting reliable substance-we were beyond the voice of our kind; conjecture as we might, there could be no answer, unless the vast snow waste was pierced, and jingling, joyful sled-bells should herald the packet from the south.

Each day we watched over the sea of lake ice to the south, each night sealed down the envelope of another span of expectancy and disappointment.

From the 23rd to the 27th I had waited at the Fort; on the night of December 27, which was a Sunday, I made final preparations to go-no hope of the packet remained, no gladsome transformation to justify my staying on and a renewal of north travel.

On the morning of the 28th a group of natives gathered about the sleds as we harnessed up.

J'Pierre and Mistewgoso were to accompany me to Pelican Narrows, which was a post in touch with Cumberland House on the Sturgeonweir River Route, which, in turn, was not very far from The Pas, which terminated the newly projected Hudson Bay Railway. They were to drive two dog-sleds loaded with specimens: chiefly Caribou, Barren-ground Wolves, and Foxes, for most of the bird-skins collected had previously been sent south by arrangement with the Furtrader.

With warm hand-shake I bade good-bye to the untrammelled, upright redskin children of the wild who were standing almost shyly about 
on the snow to wish me bon voyage and au revoir, for all had told me they hoped I would some day come again amongst them. It was a somewhat touching farewell to me, for it bore the final goodwill of rude men, not easy of approach, who had come to acknowledge me their friend, and theirs was friendship I valued. Only a day or two before the priest at the Fort had taken upon himself the task of telling me of the feeling of the Indians toward the white stranger. $\mathrm{He}$ had summed up his kindly meant remarks with : "If at any time you come back to this territory, you will have many friends among the natives ready to help you in your work, and glad to go with you on the trail, for they feel you are as one of them, and they understand and trust you--all say the same, and they are quick to distinguish." Who would not feel, who had lived among a strange race, touched and deeply grateful for such acknowledgment of comradeship?

Thus warm hand-shakes, which had nothing of conventionality about them, sent me on my way, while a parting volley of rifle shots followed from the shore as we mushed the dogs and sped out over the frozen lake on the trail into the South.

As we drew away I looked back on that diminutive settlement of cabins, husbanded together and wholly human in that vastly desolate land, and loving the strange wild North and its freedom, and its people, was disposed to repeat: "I've bade 'em good-bye-but I can't."

Gewgewsh and Napisis, who had also harnessed their dogs, ran with us till we camped at our first 
"fire," breaking the trail thus far, and making the going for our sleds easier; a final act of goodfellowship arranged by the people at the Fort. Gewgewsh had trailed with me to the edge of the Barren Grounds and had taken upon himself this delicate manner of showing friendship which is typical of the refinement and chivalry of the best of the Indians, who are sometimes, at heart, true men.

With a purpose I have dwelt at some length on the friendship of natives, for I believe that anyone who wishes to enjoy travel or sport far afield in any land should always try to accept the native as a well-meaning character, no matter how strange their lives and manners may be in contrast to our own; they are, after all, but children of circumstance, with colour, character, environment, irrevocably inherited. Their seeming stupidity, or sullen nonchalance, especially if confused by overbearing command or reproach, does often, it seems to me, come about through lack of full understanding, particularly in language, for one may not be able, in their native tongue, to say explicitly that which one means, and they, on their part, may not be capable of phrasing their own language to convey to the stranger addressed the full significance of their reply.

In any case, if early contact with natives prove difficult and trying, it is well not to be disheartened and suspicious of them, but to persevere while accepting them as strange, rude people. In the end, if this is done, there will result at least a measure of mutual understanding, and the 
stranger will find in the native many good points to counterbalance the bad. And much really good service can thereby be gained, to further the enjoyment and results of any undertaking, for undoubtedly the natives can give one valuable information of their country, which is open as a book to them, if they are anxious to be friendly, and to serve.

I have on rare occasions heard impatient people express the opinion that natives are fools; and in such cases I have been prompted to think that they have taken the natives, for the most part, in the wrong way; and that such an opinion can seldom be altogether justified. It is surely much more fair to begin with the idea that they are not fools, but just simple and untutored people, and I feel sure that if that is done in the right spirit the result in the end will bring its reward, and at the same time full appreciation be gained from the native of the standard the true white man upholds of fair play; which is also the standard he will attribute to our country.

Furthermore, dealing now with native ability, as far as the North American Indian is concerned, few white men, unless they are bred on the edge of civilisation or long accustomed to life beyond the frontiers, in my humble opinion, can compare with the red man in travelling great tracts of unmapped territory when they enter country they themselves have not known before. The speed at which they can cover rough country, and their instinctive sense of true direction, are incomparable and little short of miraculous; and often leave the white man's 
prowess far in rear. Nor is this logically to be wondered at, for the nomad primitive Indian is born and brought up to bush travel; it is to him second nature, while to our more gently cultured race it often carries the experience of an unexpected robust education.

Creatures of the wild, and akin to animals in their adaptability to their surroundings, Indians have from their beginning been a race of able hunters and wanderers; lithe of sinew, sound of lung-enduring, and, most highly developed characteristic of all, endowed with peculiar, unerring, intuitive scent for trail or direction.

One could not wish for better henchmen on the trail, but, at the same time, it is difficult to enlist their service, particularly if the journey proposed is to be a long one. There are two prominent reasons why the red man, on most occasions, hesitates to accompany a white stranger on a long trail. Firstly, it is seldom the red man's custom to leave his lodge of women and children for any lengthy period, for they are largely dependent on him for food and management of camp life; while, at the same time, the man's presence is to his women-folk a safeguard against danger of any kind. Secondly, they are dubious that the white man may possess strange ideas in his pursuit of his objective, and that he may not foresee the dangers and hardships ahead as clearly as they do in their fuller experience; which prompts the fear that the white man might lead them into a tight corner and needless dangers, against which they, when by themselves, would accurately forecast and avoid. All of 
which is of course reasonable from the Indian's point of view, and should be understood and considered if one meets with rebuffs when setting out to look for guides. They are, however, individually open to the persuasion of a stranger, and it is nearly always possible to find the right man in the end. And once this initial step is accomplished toward mutual understanding, and the stranger becomes known and trusted on a territory, his difficulties in that direction largely cease.

And now, to return from this brief digression to the south-bound sleds that had left Fort Du Brochet, we were soon far out on Reindeer Lake beyond all sight of dwelling or fellow-mortal; we might have entered a land of the dead, so soon had all vestige of that tiny, closely infested settlement been overwhelmed by vast surroundings.

This journey undertaken, so far as I was concerned, was now simply a question of straight trailing. Four hundred miles away, following a route almost due south, lay the Pas and the Hudson Bay Railway: for that point I was heading. The first stage on the way was Pelican Narrows ; thus far were J'Pierre and Mistewgoso to transport the sled-loads of specimens, and thence return on their back trail.

But from day to day I will briefly deal with my onward-hurrying journey to the south over frozen lakes and forests lain deep with snow.

December 29.-Travelled all day on Reindeer Lake, Frozen-over ice floes were very bad all along 
the north shore of Porcupine Point, where windpressure, before the ice was very thick, had broken through the weak areas and piled up angular blocks on the resisting lake surface. There, accordingly, progress for the sleds was for some considerable distance awkward and slow, and some time was lost.

The day was bitterly cold, so cold that when I took a photograph in an exposed position on the lake, and removed my right-hand mitten to do so, I had my finger frozen in but a brief time. Application of snow rubbed on vigorously soon restored circulation.

Ten Caribou were sighted between our second fire and night camp, and we gave chase to secure dog-food. Both Indians (one of whom used my rifle) brought down a buck apiece, and at long range I, later, dropped a third from the same herd. Each then hoisted a dead animal on the top of the sled-loads, and roped them securely; and when this was done we resumed our way until it was time to camp for the night. At camp the Caribou were off-loaded and cut up, and the dogs well fed, while the remainder, excepting that which was required for our personal needs, was cached by the Indians for use on their return journey.

In camp we slept on spruce boughs on the snow, snug in our Caribou-skin sleeping-bags before a great log-fire, as was ordinary custom on the winter trails.

December 30.-Left our night camp about an hour before daylight, and made good progress throughout the day. There had been no snow- 
storm so far, but the air to-day was heavy, and fog hung over the lake in the distance, while it remained bitingly cold, and the dogs, as usual, were white with the back-flung frozen moisture of their breathing.

A few Caribou were sighted far off at dusk, but we did not attempt to follow them. At no other time this day did we see a single living creature on the great motionless wastes of snow.

December 31.- To-day heavy white fog enwrapped Reindeer Lake until late afternoon, and all landmarks were hidden. After our first fire the Indians lost their true direction and were for a time at a loss. Soon, however, they doubled back on their tracks, and eventually picked up old signs to eastward.

This night we camped at a Cree's wigwam on the east shore of Reindeer Lake, about half a day's journey from the south end. Here we partook of the Indian's hospitality within the crowded smoke-filled confines of his primitive dwelling. Food was soon forthcoming from the large black pot which hung in the centre of the teepee over a good fire from which the wood-smoke leisurely ascended, to finally percolate through the opening at the peak overhead or sneak through the seams of the small door-flap. When food was ready, we strangers were first served, with vessels piled to mountainous heights, with Caribou meat, which was placed on the ground before us by the women-folk. Soon the two men of the Cree family also commenced their meal, after withdrawing a little apart; and I passed on to them a portion of my sugar store and bannock, as 
was customary, and they in their turn, as they invariably do, reserved some of these dearly loved delicacies for their women and children, to whom the leavings of the men's repast is always finally passed.

The full meal over, pipes were brought out and filled from my store of tobacco, and we sat and talked in low Indian voice in an atmosphere that was thick, and hot, and stifling, and decidedly uncomfortable to a European, though unremarked by the Indians, to whom it is habitual-small wonder they breed consumption! The meanwhile the two elderly women squatted cross-legged on the floor in the Indian fashion and patiently laced with sinews the snow-shoes they were making, much as a white woman employs herself with knitting; also one of the men whittled wood for sled-pieces, while three girls amused themselves over the ornamentations which one of them was sewing on a pair of moccasins for a lover.

Exchanging stories to pass the evening, the eldest Indian of this camp told the following : "There was once an Indian on Jack Fish Lake who successively married six wives, each of whom died within a year after marriage. When the sixth wife died he despaired, and said: 'Is there a Great Spirit?' Furthermore, in his distraction, he told his kinsfolk that he would go in his canoe down the Cochrane River, avoiding not the awful rapids down which no man had been known to pass ; "for if there is a Great Spirit, as people say, he must be strong enough to protect me from the hungry waters." Launching his 
canoe, caring for nothing in the world, he set off on his hazardous journey. Miraculously-so the story goes - he made the voyage, and reached Reindeer Lake in safety, and thereafter firmly believed that there was a Great Spirit. Moreover, he married a seventh wife, who did not die as the others had done."

January 1, 1915.- In the afternoon we reached the Fur Post at the south end of Reindeer Lake, after having been almost five successive days in travelling down the great lake.

At the Post we took on sufficient frozen fish to feed our dogs to Pelican Narrows; then pulled out again and trailed onward until an hour after dark, when we camped for the night at the first rapid on the upper reaches of the Reindeer River.

January 2.-Travelled hard all day overland through rough, hilly country west of Reindeer River, while it snowed incessantly.

Reindeer River.course is not used as a winter route by the Indians, a more direct and untwisting course being chosen in preference to the west of it.

January 3.- In the dark of early morning, as was customary, we moved out to take up the trail again. When day broke the sky was dull and despondently grey, but the snowstorm had ceased. The trail to-day was like that of yesterday: hard and difficult when traversing the country overland between the lakes, seven of which we travelled through before making connection to Reindeer River, which we reached about noon. 
Toward evening we passed out of Reindeer River on to the Churchill River, and thence through an overland route east of Frog Portage, on to the Lake of the Woods ; where we camped for the night within one day's journey of Pelican Narrows.

The inland country which we passed through to-day was irregular and mountainous, necessitating steep climbing and awkward descents for our sleds. Poplar trees are now encountered in plenty, which trees were rarely seen in Fort Du Brochet territory.

January 4.-Pushing onward, we kept the sleds going steadly all day, often over long and bad overland bush-trails.

This day was dull in the morning, but the afternoon broke particularly fine; bright sunshine shone in a soft, wistful sky, and there was no bitter wind; fresh-fallen snow lay unruffled on the lakes, white as the finest linen; sunbeams glittered; and to add to this, we were passing through particularly picturesque country-narrow lakes lying peacefully between high, forest-covered hills.

About twelve miles north of Pelican Narrows we crossed fresh tracks of Woodland Caribou, which was the first and only retreat of this animal encountered throughout the expedition.

About 5 p.m., considerably excited at the prospect of reaching a settlement, we neared Pelican Narrows, and soon afterwards drew up before the Hudson Bay trading store, to be made cordially welcome by the Factor.

Before reaching the Post, J'Pierre had pointed 15 
to some horse-tracks in the snow; in some excitement, and with a broad smile, saying : "Not dog, not deer-what you call it ?" Meaning that here was something closely associated with the white man, and therefore drawing my attention to that which he thought must be dear to me. At $\mathrm{Du}$ Brochet horses were unknown, but in full winter they travel over the ice to the post we had now reached with substantial loads of such stores as once a year recuperate the Far North Trading Posts.

It is 230 miles from Fort Du Brochet to Pelican Narrows on the map; possibly it is 250 miles, or more, by the trail we followed. We had trailed the distance in one straight run in eight days, thereby averaging thirty-one miles a day ; accomplishing under thirty miles a day when the country or weather conditions were distracting, and over thirty miles when the trail was favourable. Such steady travelling, with formidable loads, is tribute to the endurance of sled-dogs, and to Indian skill in keeping, unguided by map or mechanical record, on a direct course to a faroff destination.

January 5 and 6 I spent at Pelican Narrows; resting the first day, and delayed on the second on account of the Indians who I had arranged were to go with me to transport my specimens, for here my Du Brochet Indians had completed their task, and would return home.

At Pelican Narrows I found letters from home -those that should ordinarily have travelled by the Christmas packet to Du Brochet. The delay of the packet was here solved: the war 
had dislocated the fur trade, and the Hudson Bay Company were not anxious to continue buying until the world-wide confusion in commerce steadied, and pointed to some definite stability. Prices of furs were away down, which the Fur Posts already knew. There was no change at Christmas, and thus the officials in authority were waiting and hoping for change in the prospects of the trade; if that came, then would they send forth their sled-packets to carry news that their Posts would welcome.

My letters were enlightening in regard to the war, and brought relief in that all was well at home; but they left me more restless than before to hurry on to the south.

At daylight on the 6th I bade good-bye to J'Pierre and Mistewgoso, and watched those sturdy travellers and their splendid dogs start back north on their long trail home. Should they go back as quickly as they came (and they would probably now go faster without loads) they would have covered five hundred miles in sixteen days, with but one day's rest.

John and Philip, two half-bred Indians, have here taken over my sled-loads of specimens, and so I resume my journey, to-morrow, with strangers.

I passed the day very agreeably with the Hudson Bay Factor at Pelican Narrows, and greatly enjoyed conversing with a fellow-countryman. He was a man who fully came up to one's pictured ideal of the fine old type of Hudson Bay servant; strong and of the outdoors, yet gentlemanly without the telling or prompting of neighbourly society. He was one of the fine 
old school of pioneers, for he had served all his life with the Company, as had his father before him. He had had one break in his life, when he had as a boy been sent to Scotland to be educated. A point which proved the Factor's worth was the fact that he was popular among the Indians, not only at his own Post, but far out on the trails : indeed, in this way I had heard of him long before I met him. And Indians are sure in their judgment, for they are gifted with extraordinarily keen penetration, and are, moreover, very exacting critics.

In the early morning of January 7 , with strange companions and fresh dogs, I resumed my journey south on Heron Lake.

We travelled hard all day and camped at night at a settlement of Cree Indians, a little above Birch Portage on the Sturgeonweir River. Here, at this settlement, one could surely tell, in the manners of the Indians, of nearer approach to civilisation, for in small but essential ways they differed from the natives in the Far North; their reserve and inherent culture-if I may use the word-were less.

Especially were the children more bold. In the Far North they were wont to retire, at a white man's approach, to hiding within their teepees, like frightened rabbits to their warrens; here, however, they ventured outdoors to stand in awed groups some distance in the background, gazing in wonderment at the white man and his belongings, the while their eyes, and downcast glances at each other, plainly told their full curiosity. 
January 8.-Two hours before daylight we left the Cree settlement and travelled overland the greater part of the day, thus avoiding the indirect course of the Sturgeonweir River, which we did not again come out on, until late afternoon, when we followed its course until after dark, to camp finally on the north shore of Beaver Lake.

I might here note, since we are travelling longer hours to accomplish a full day's run, that the dog-trains of the Indians now with me are a very mixed lot in breed, and of diminutive size; and far below the standard of the stalwart Du Brochet huskies. It is but another omen of approaching civilisation; and, had I wanted further evidence, I saw to-day, on passing some cabins, a cowwhich, without mistake, brings one near to the old familiar world.

January 9.-We passed through Beaver Lake when setting out this morning; a lake where gold was discovered late last Fall, but which, I learned at Pelican Narrows, had not so far realised the great things that were hoped for by those who rushed to the claims. Nevertheless shacks had sprung into being, and those and other signs of human occupation invested the lake, even in the dead of winter. And it was here that a husky in John's train, the only pure looking dog in the lot, grew wildly excited as we passed a horse-sled, and strained on the traces to give chase, apparently mistaking the horses for deer. I asked John where the dog had come from, and he replied "Patatawogan," a post on the Lower Churchill River, where Caribou frequent. The dog was a 
beast of the wild places and yet untamed to civilisation.

Before trailing far to-day, Philip's dogs began to give out, and consequently the loads had to be altered and his sled much lightened.

After leaving Beaver Lake we crossed overland for twenty miles through forest country to Cumberland Lake, which lake we crossed before finally drawing up at Cumberland House. It was then so far into the night that all the inmates of the Fur Post were in bed, but necessity of food and desire for shelter forced me to awake the inmates, who in due course, in spite of my rude intrusion, bid me welcome in by the light of flickering candles.

We had trailed forty-five miles this day and, moreover, had run incessantly behind the sleds on account of the played-out dogs-truly we were ready for food and rest.

Here ended, in memorable fashion, my travels with dogs, 350 miles south of Fort Du Brochet, or 550 miles south of the edge of the Barren Grounds.

January 10.--I remained at Cumberland House during the day, while arrangements were made for a sled drawn by horses to carry myself and my specimens to the Pas on the morrow.

Cumberland House had lost much of the old character of a Fur Post, and had the appearance of fast becoming a white man's frontier station : a change no doubt aggravated by the discovery of Gold at Beaver Lake, and the consequent invasion of miners and prospectors; while also it is influenced to change by the advent of the 
new Hudson Bay Railway to the Pas, which brings a measure of civilisation in proximity.

Nevertheless I spent a very pleasant day there, conversing with people of my own kind in my own tongue; even though I missed the rarer atmosphere of the wilds, and the wild man's ways, that appertain in the Further North.

January 11. - The remainder of my journey south was of little account and may be briefly told.

Leaving Cumberland House, I travelled all day by horse-sled, and camped for the night in the Saskatchewan Valley about fifteen miles west of the Pas; and next day completed the distance to the railway terminus.

The following day I boarded the train and, via Prince Albert, reached Regina, my destination, at midnight on January 14 .

One or two peculiar and amusing incidents occurred in those first days of my return to civilisation.

I had, of necessity, no European clothing, and was therefore, to my embarrassment, clad in my rude Eskimo costume. I will not readily forget the steward on the dining-car on the train when, in this garb, I first entered for a meal; nor his subsequent astonishment when I requested him to bring me vegetables only-first one course; then another; and yet another, while his face lengthened in perplexity; and he finally told me there were no more vegetables on the train. I probably looked a grim customer, but by the time he had finished serving me I felt satisfied that he thought I was mad. Nor did he look 
altogether credulous when I told him at the end of the meal that I had not tasted vegetables for nine months, and that prolonged fish and meat diet had given me a tremendous craving for them; and that therefore he had given me the finest meal I had ever enjoyed.

At Prince Albert my clothing afforded me further embarrassment, for I was an odd figure among the city population, but particularly were the dogs in the streets disconcerting, for they scented the strange smell of the Caribou skins (for they retain a peculiar, ineradicable scent of the type one associates with Harris tweed) and would circle behind me to follow curiously, and sometimes to bark alarmingly. At times as many as half a dozen dogs had gathered about me in this way, until I found it expedient to turn down a side street and chase them away.

Still further, my home and worldly belongings of the previous year were at Craven, twenty miles away from Regina, so when I reached the latter city, I had to spend the day in Arctic garb. In the evening I dined with some old friends, who were amused and kind enough to take my Eskimo clothing in good part. Moreover there was a fancy-dress Carnival at the skating-rink that night, and they persisted in persuading me to accompany them there. This, in the end, I consented to do, and on reaching the rink skated on the ice until the costumes were judged, whereupon I was awarded the first prize-and I had not changed an article of my everyday Far North Caribou clothing. ... 
So had I come off the long trail to my own people. Soon was I speeding east, and to England, and to war, but carrying memories that nothing could erase of the wonderful country I had seen in a virgin land of the Wild.

The years of war have passed since then, yet so great is the attraction of that vast lone land that sleeps in the lap of a mighty Destiny, through endless summers of lovely garbing, and winters of drear snow wastes, that I still can repeat, "I've bade "it' good-bye-but I can't." Some day, if I live, I will go back. 


\section{CHAPTER $\mathrm{X}$}

\section{ANIMALS AND BIRDS COLLECTED AND OBSERVED}

Iist of Mammals, and where Collected and Noted DURINg this Expedition of 1914. ${ }^{1}$

Moose.-Observed Crooked River, May 13. Two observed above Pelican Rapids, Churchill River, June 2. Had fresh meat from Indians on Sandy Lake on the Churchill River, June 9. Many tracks of moose on the clean, soft riverbottom in neighbourhood of White Sand Rapid, Reindeer River, June 30. Few in neighbourhood of south end of Reindeer Lake ; report of Solomon Cook, July 1. Willows on shores of lower reaches of the Cochrane River much eaten by those animals, July 19. Many signs of moose on inland lake shores west of Cochrane River, July 23. Some skins of both adult and young moose at Fort du Brochet, August 21. Few tracks in the snow encountered west of Reindeer River, on return journey, January 2, 1915.

Woodland Caribou.- In two instances the tracks of this species were seen in the snow about twelve miles north of Pelican Narrows, January 4, 1915. Some nice heads of this species in Hudson

1 See also Report of Chief Game Guardian, 1914, pp. 33-4, Regina, 1915. 
Bay Factor's cabin at Pelican Narrows, January 15.

Barren-ground Caribou.--See Chapter VI.

MusK-ox.-A number of skins were seen east of White Partridge Lake, twenty miles south of the Barren Grounds, November 26. They had been taken by Eskimos in territory further north.

Woodchuck.-One trapped Beaver River, May 19.

Chipmunk.-Observed on an island on Sandy Lake on the Churchill River, June 11. The first specimen seen for a long time; and the only one noted during the remainder of the expedition.

Réd Squirrel.-Feard chattering in spruce forest on shores of Black Bear Island Lake on the Churchill River, June 14. Observed on shore of Rapid River Lake, Churchill River, June 24. One taken on shore of Sucker Bay, south end Reindeer Lake, July 5. Observed Cochrane River, July 24. One taken north of Fort Du Brochet, October 31.

Musk-Rat. - Observed on Sandy Lake, Churchill River, June 9, and in marsh in neighbourhood of Fort Du Brochet in August.

Canadian Beaver.-Few dams observed north of Fort Du Brochet in September.

Porcupine.-Observed Ile à la Crosse Lake, May 27. Observed swimming in water Sandy Lake, on the Churchill River, June 11. Again observed this species swimming on Island Lake, Churchill River, June 26. Later the animal climbed a poplar tree.

VARYing HARE, or White Rabbit.-One male taken inland west of $\mathrm{Du}$ Brochet Lake : this the 
first " rabbit" seen since leaving Lake Ile à la Crosse. Many signs of "rabbits" on shores of Du Brochet Lake, August 2, but not a single one seen. One shot north !of Fort Du Brochet, October 1, but this territory, at least for the present, appears almost barren of this species. It is highly probable that rabbit plague has recently devastated the territory of this species, for there remain everywhere old signs of great numbers.

LyNX.-Observed tracks of this species in the snow when journeying south, which tracks were the first encountered. No tracks or pelts noted in the Far North-my position, when tracks encountered, was in very broken, rough country west of Reindeer River, January 2, 1915.

Timber Wolf, Grey Wolf.-Few stated to be in neighbourhood of south ena of Reindeer Lake by Solomon Cook, halfbreed servant, July 1. Found den at edge of small mossy swamp in large muskeg, Du Brochet Lake, August 3. There was a great gathering of small twigs, grass, moss, etc., at entrance to den, and inside; tracks of wolf in many places on the lake shore, which was not far distant. Meat cache plundered near Thanout-Tua Lake, latitude $59.5^{\circ}$, on November 24 , by Wolves, Wolverine, and Foxes, whose tracks were numerous in the snow. Few skins seen east of White Partridge Lake, twenty miles from the Barren Grounds, November 26. Two specimens taken east of the north end of Reindeer Lake, December 22, in same locality as White Wolves-all being attracted by the carcass of a Caribou. Two 
Wolves, which appeared to have run amok, were shot at the cabin doors of Fort Du Brochet on December 19, 23, after causing much fear and excitement among the natives. I examined the second animal which was killed, and found it mangy and lean and frothed at the mouth; it was quite evidently insane. One blackishbrown specimen observed on Beaver Lake, January 9, 1915.

Barren-ground Wolf, White Wolf.-Many skins seen in trapper's cabin east of White Partridge Lake, twenty miles south of the edge of the Barren Grounds, November 26. Specimens, all white except for small black mark on the upper side of the tail near the base, were taken east of the north end of Reindeer Lake on December 22 ; they were male and female, and are now mounted in the Provincial Museum, Regina, Saskatchewan.

Cоуоте.-Single one observed at Big River, May 10, and many heard howling at night. None seen or heard at Ile à la Crosse Lake. Note on Sandy Lake, Churchill River, on June 10, that I have not seen or heard this species since reaching Ile à la Crosse Post. Solomon Cook, halfbreed servant, tells me there are none in neighbourhood of south end of Reindeer Lake.

Foxes-Red, Cross, Black.-Red foxes observed Sandy Lake, Churchill River; June 8; Dead Lake, Churchill River, June 17. One observed north of Fort Du Brochet November 5 (see "Timber Wolf," November 24). A good specimen of Cross Fox taken near Fort Du Brochet on December 17. One Red Fox seen feeding at 
remains of Caribou carcass, Reindeer Lake, December 20. Measured great fox-jumps in the snow-they were $9 \mathrm{ft}$. $9 \mathrm{in}$. apart from forepaws to fore-paws. West of Reindeer Lake, January 2, 1915.

A beautiful male Black Fox trapped by Jaumeri Merasty, jet-black except for few silver hairs over rump, and white tail-tip. Taken south of Fort Du Brochet, December 9 : eventually purchased by Revillon Brothers, Factors, for $\$ 200=£ 40$.

Arctic Fox, White Fox.-Many skins were seen east of White Partridge Lake, twenty miles south of the Barren Grounds, November 26, and this species was known to be common in the neighbourhood. One taken north-east of Reindeer Lake, December 22.

Black Bear.-Observed below Knee Rapid, Churchill River, June 5.

Brown Bear.-Very large specimen observed below Key Falls, Churchill River, June 25.

OTter.-Observed on Crooked Lake, May 12. Skin seen in trapper's cabin on island at north end of Reindeer Lake, December 29.

Skunk.-One trapped on Beaver River, May 20.

MrNk.-Observed carrying an eel in the water, Island Lake, Churchill River, June 26. Two Mink skins seen east of White Partridge Lake, near the edge of the Barren Grounds, November 26. Tracks in snow noted near Pelican Narrows, January 4, 1915.

WEASEL. - Secured specimen in summer fur near Fort Du Brochet, July 16. Observed Cochrane 
River, July 24. One taken north of Fort Du Brochet, December 5.

Marten.-Observed on Theitaga-Tua (Lake) near latitude $60^{\circ}$, November 25. Many skins looked over east of White Partridge Lake, twenty miles south of the Barren Grounds, but no Marten among them, November 26. One taken north of $\mathrm{Du}$ Brochet Lake, November 29.

Wolverine.-See "Timber Wolf," November 24. Skins seen east of White Partridge Lake in latitude $60.5^{\circ}$, twenty miles south of the edge of the Barren Grounds, November 26.

List OF BIRDs, AND WHERE COLLECTED AND Noted DURING this Expedition of 1914 ${ }^{1}$

Note.-Where name of species is not within square brackets, specimens have been carefully examined and identified by Mr. J. H. Fleming, C.M.Z.S., C.M.B.O.U., and the references to actual skins, which are made in the following list, are those which he has kindly made in writing a paper on the collection.

A few more species might have been added to the list of those observed, but their identities were not positively established and they are omitted for the present. The data below contains the names of a great many species, but owing to limited time, and to the virgin nature of the North country, its vast extent, and the unlimited cover it affords to bird or beast, it is not possible that all birds common to the territory have yet been noted.

I Seo also Report of Chief Game Guardians, 1914, pp. 33-4, 37-9, Regina, 1915. 
Bird life was found most plentiful in the territory west of Stanley Post, on the Churchill River, and south to the point of starting on Lake Ile à la Crosse, and the various other waterways. Along that part of the route the land and vegetation and forest were of a richer, more attractive nature than further north, and no doubt that accounted for the greater presence of bird life.

In travelling through the somewhat barrenlooking territory of the Far North, birds, with few exceptions, were encountered at rarer intervals and in fewer numbers. Ducks were notably very scarce, while, on the other hand, some of the sparrows were numerous and had their first encountered breeding-grounds north of latitude $58^{\circ}$.

[HoldBøLl's Grebe (Colymbus holbœlli)].--Set of five eggs taken on Churchill River, June 6 ; bird seen at close range. Nest a pile of rotten weeds, in open water among scant floating raft of dead weeds. Nest elevated two or three inches above water limit, but the whole watersoaked. Nest close to marsh shore in narrow inlet in Churchill River, some ten or fifteen miles below mouth of Haultain River.

Observed Beaver River, May 19, 20, and in marsh above Sandy Lake on the Churchill River, June 8.

[Horned Grebe (Colymbus auritus)].-One pair observed on inland lake east shore Ile à la Crosse Lake, May 30; female taken.

[EARED GREBE (Colymbus nigricollis californicus)].-Observed Crooked Lake, May 12, 13; Beaver River, May 19. 
Loon, Great Northern Diver (Gavia immer).-An adult takenl on Reindeer Lake, July 8.

Observed Crooked Lake, May 12. A few observed Sandy Lake on the Churchill River, June 10. Two observed on Black Bear Island Lake on the Churchill River, June 14. Observed Otter Lake, Churchill River, June 20. Two observed in neighbourhood of the mouth of Reindeer River, June 27; heard calling at night now, or before high wind rises : a solitary drawnout call, cool ... ou . . .; a most striking call of the northern wilderness. Many observed at south end of Reindeer Lake, July 3, 4. Observed Reindeer Lake, July \%, noted to be not so numerous on July 9. Few observed Reindeer Lake, July 10: when in flight the feet project conspicuously behind, like a tail. One observed Reindeer Lake, July 13. Observed Cochrane River, July 21. One male taken on the Cochrane River, July 23, length 30.5 in; bones of small fish in stomach. Observed July 24, 26, 27 on Cochrane River; Du Brochet Lake, August 5 ; calling before onset of a storm, and flighting restlessly. Observed north end $\mathrm{Du}$ Brochet Lake, August 10, 12 ; Cochrane River, on return journey, August 14, 15.

[RED-Throated Loon (Gavia stellata)].-Observed for first time in Sucker Bay, south end Reindeer Lake, July 6. Observed one pair on Reindeer Lake, July 8 : birds wild, and difficult to get within gunshot. One observed Cochrane River, July 19. Few observed on inland lakes west of Cochrane River, July 23, 24, 26. One 
observed Cochrane River, July 27: these birds seem impossible to secure, so wild are they. Four observed Du Brochet Lake, August 7, warned of their presence by their cat-like Awe-Awe call ; a cry very different from the harsh, rumbling quack which they utter when flying. Observed north end $\mathrm{Du}$ Brochet Lake, August 10, 12 ; fairly numerous on this lake, but all very wary. Observed on Cochrane River, on return journey downstream, August 13, 14, 15.

[JAEGAR? (Stercorarius parasiticus?)].-Single bird observed on Sandfly Lake on the Churchill River, June 12. Specimen dark above, white below from bill down, with dark ring circling under neck. This was the only Jaegar observed throughout the expedition.

[CAliffornia Gull? (Larus californicus?)].Three observed over the Saskatchewan River, Prince Albert, May 5. One taken Shagwenaw Lake, Churchill River, June 1. Nesting on island on Sandfly Lake, Churchill River, in company with common Terns, but the nests of this species were all together among tufts of grass growing on the higher parts of the island. Nests contained generally three eggs, one contained four, June 11. Observed Otter Lake, Churchill River, June 20, and Key Lake, June 24. Few observed Island Lake, Churchill River, June 26 ; Reindeer Lake, June 28. Halfbreed, Solomon Cook, tells me that Indians eat Gulls, particularly this Gull; south end Reindeer River, July 1. Observed at south end Reindeer Lake, July 6 ; Reindeer Lake, July 7, 9. Few nests found on an island where many common Terns were 
nesting, one nest contained young newly hatched, Reindeer Lake, July 12. Observed lower reaches Cochrane River, July 18, 21 ; west of Cochrane River, July 24; Cochrane River, July 25, 26, 28, 30, 31; Du Brochet Lake, August 1, 5, 6; north end Du Brochet Lake, August 10; Cochrane River, on return journey, August 14, 15.

ShorT-BILled GulL (Larus brachyrhynchus).An adult female taken on Reindeer Lake, July 9, one more seen on same date; this is very far east for this gull. "Iris clear blackish-grey; edge of eyelid surrounding eye deep orangechrome; corners of mouth pure orange-chrome; bill evenly coloured dead yellow; feet pale whitish-yellow." Dr. Oberholser regards this gull as a subspecies of Larus canus. ${ }^{1}$

Ring-Billed Gull (Larus delawarensis).-A male taken on Ile à la Crosse Lake, May 23 ; adult except for the black primaries and terminal band of the tail; probably a non-breeding bird. "Bill medium dark greenish-yellow, with strong black ring around bill a short distance from tip; eyelids, and corners of mouth, deep orangechrome; feet pale greenish-yellow." Seventeen others seen with this bird.

An occasional Ring-billed Gull observed Ileà la Crosse Lake, May 25.

Bonaparte's Gull (Larus philadelphia).-Four specimens, an adult male (thought by the collector to be a non-breeding bird), taken on the Cochrane River, July 20. "Iris dark; bill black ; legs and feet, orange-chrome." An adult

$$
1 \text { Auk, xxxvi, 1919, pp. 83-4. }
$$


female, taken on Cochrane River, July 25. "Iris dark; eye-ring dark crimson; bill black; corners of mouth reddish-flesh colour; legs whitish orange-chrome; feet more rich chrome." Two juvenile birds taken on Lake Du Brochet, Cochrane River, August 1: one of these, a female, is marked "Iris dark; bill medium dull blackish grey; both mandibles dark from nostril out; legs, feet, and webs whitish skin colour with pale brown joints." This species is believed to breed in trees, and it is unfortunate in view of the young birds taken, that the nesting site was not found.

One pair observed Crooked Lake, May 12 ; small colony seen on inland lake off the Beaver River, May 19; birds commonly perched on limbs of dead trees on the edge of the forest which surrounded the lake on three sides. An occasional bird of this species observed Ile à la Crosse Lake, May 25. One observed Cochrane River, July 26 : three observed Cochrane River, July 27.

Sabine's Gull (Xema sabini).-Three seen, and a pair of adults taken, on Sandy Lake, Churchill River, June 9 ; the female is marked" iris black; pure red eye-ring; bill, black to one-eighth beyond nostril, remainder of tip medium dull lemon-yellow ; feet black."

Common Tern (Sterna hirundo).-A juvenile female with pinions not fully grown, taken on Cochrane River, August 14. Seen in company with parents and another young bird.

Few observed Beaver River, May 21, and Ile à la Crosse Lake, May 25. Breeding haunts observed on Pelican Lake, June 3, 4. 
Breeding on small low stony island at last bend on the Churchill River above Sandy Lake, June 8. Nest, small hollows crowded together; grass-lined isometimes. They contained generally two eggs and three eggs each, a few held a single egg. Estimated there were some three hundred eggs on this island. Observed Sandy Lake, June 9. Nesting as above on islands on Sandfly Lake, Churchill River, June 11.

Nesting on two small islands in Island Lake. Few nests contained two eggs, but the general rule was three. All eggs were well incubated, but in no case had young hatched; Churchill River, June 26. Nesting on island above Kettle Falls, Churchill River, June 27 ; observed Reindeer River, June 29; Reindeer Lake, July 3. Visited island where those birds were nesting; no young hatched out yet, south end Reindeer Lake, July 4. Observed numerously in Sucker Bay, Reindeer Lake, July 6. Observed Reindeer Lake, July 7. Visited island where colony nesting, and there saw first young birds, which were just hatching out, chipped eggs and moist chicklets being numerous, Reindeer Lake, July 12. Observed Cochrane River, July 18, 24, 25, 26, 29, Du Brochet Lake, August 1, 6; Cochrane River, on return journey, August 15.

[Black TeRN (Hydrochelidon nigra surinamensis)].-Observed Beaver River, May 19, 20. So far no birds of this species observed on Ile à la Crosse Lake, May 25. Numerous on inland lake on east shore at north end of Ile à la Crosse Lake, May 30. Colony of birds found just commencing to lay in same locality, May 31. Single 
eggs in the few nests that contained any. Hundreds of birds nesting on the water surface at the outer edge of the weeds. Breeding haunts found Pelican Lake, Churchill River, June 3. Observed Knee Lake, Churchill River, June 6; Sandy Lake, Churchill River, June 9.

[White Pelican (Pelicanus erythrorhynchos)].None seen on Pelican Lake, Churchill River, June 3, 4. About thirty observed at rapids between Sandfly Lake and Black Bear Island Lake on the Churchill River, June 12.

Merganser (Mergus americanus).-A male in very worn immature plumage taken below Ile à la Crosse Lake, on the Churchill River, June 1. "Iris dark; bill medium deep crimson, crown of upper mandible black; feet bright orange-chrome.

Observed Pelican Lake, Churchill River, June 4; Trout Lake, Churchill River, June 15 ; Reindeer Lake, June 28; numbers at south end of Reindeer Lake, July 3. Few observed Reindeer Lake, July 10.

Red-Breasted Merganser (Mergus serrator).- - An adult female taken on Ile à la Crosse, May 23. "Iris clear deep umber brown; bill all red except along crown of upper mandible, which is dark horn-brown; legs and feet rich reddish orange-chrome."

A downy young female, length $14 \cdot 75$ in., taken on the Cochrane River, August 15. "Iris pale clear brownish sage-green; bill blackish brown over crown of upper mandible for entire length except tip, sides of upper mandible and entire lower mandible pale dull buffish yellow; legs 
and feet dull brownish grey; neck dull umber brown. Bird in company with mother and about a dozen young."

Set of twelve eggs taken on rocky island in Reindeer Lake, July 12. " Nest found on ground concealed beneath ledge of rock, eggs almost hard on rock, and rim of nest composed of small leaves and twigs profusely mixed with blackishgrey down."

Two pairs observed south end of Ile à la Crosse Lake, May 22. Large numbers observed on Black Bear Island Lake on the Churchill River, June 14, and above Trout Lake on the same river on June 15. One observed Otter Lake, Churchill River, June 20. Few observed at rapid above Key Lake, Churchill River, June 24. Numbers at south end of Reindeer Lake, July 3. 4. Numerous in Sucker Bay, Reindeer Lake, July 6. Observed Reindeer Lake, July 7, 9. Numerous Reindeer Lake, July 10. Observed Reindeer Lake, July 12 . Observed Cochrane River, July 24, 28, 29, 30, 31 ; Du Brochet Lake, August 1, 2, 6; north end Du Brochet Lake, August 12.

[Mallard (Anas platyrhynchos)].-Observed Polwarth, Sask., May 6; Big River, May 9; Crooked Lake, May 12. Nest containing three eggs found on May 13. Observed Beaver River, May 19, 21. Few observed on Ile à la Crosse Lake, May 25. Five observed inland from Ile à la Crosse Lake, May 30. Numerous on Shagwenaw Lake, Churchill River, June I. Nest containing nine eggs found in dry grass marsh ; nest composed of blackish down and a few dry pale-yellow grasses, 
situated beneath a tussock of grass, Churchill River, June 2. Numerous Pelican Lake, Churchill River, June 2, 4; observed below mouth of Haultain River on Churchill River, June 6.

Found nest with eight eggs in damp dead weeds at the very edge of marsh shore; site more in swamp than is usual. Mallard very numerous in marsh above Sandy Lake on Churchill River, June 8. Observed on Sandy Lake, Churchill River, June 9. Few observed on Black Bear Island Lake on the Churchill River, June 13. Few observed Dead Lake, Churchill River, June 17. Duck, on this lake, very scarce. Duck most plentiful, so far, in neighbourhood of Pelican Lake. One or two observed on Island Lake, Churchill River, June 26 ; still remark that ducks are very scarce.

On island above Kettle Falls found three mallards' nests containing respectively ninenine-and eight eggs, all in early stage of incubation, Churchill River, June 27.

One or two observed Reindeer River, June 28, 30 ; south end Reindeer Lake, July 4.

Observed female with nine young in water, but this species appears very scarce here, as those are the only ones seen during the last few days, Reindeer Lake, July 8. Female observed on lower reaches of the Cochrane River, July 18. Female with few young observed Cochrane River, July 21 ; another with young on July 23 . Two observed, Cochrane River, July 27. Observed with young almost fully grown, Cochrane River, July 28. One observed north end Du Brochet Lake, August 10. Observed family of full-grown 
young chased by falcon-like hawk, which I was unable to positively identify, Cochrane River, lower reaches, August 15. Hunted duck for food north of Fort Du Brochet on September 23, 24. Noted duck very scarce. After searching far for them during two days, secured six mallard, one wigeon, one Golden-eye, and only saw two others. Searched for duck north of Fort Du Brochet on October 6, but saw none. Have concluded during last few days that all duck species from the Far North have now migrated south. First heavy fall of snow on October 3, again on October 17.

[AMERICAN Wigeon (Mareca americana)].Observed at Big River, May 9; above Sandy Lake on the Churchill River, June 8, and on Sandy Lake, June 9. One taken north of Fort Du Brochet, September 24, and observed in same locality on September 26.

Green-winged Teal (Nettion carolinense).A pair taken on the Beaver River, May 18.

Fairly common on Beaver River, May 21. One pair observed Ile à la Crosse Lake, May 25; numerous on Shagwenaw Lake, Churchill River, June 1, observed on marsh above Sandy Lake on the Churchill River, June 8.

[Blue-winged Teal (Querguedula discors)].Observed Big River, May 9 ; Beaver River, May 19, 21. Drake Blue-winged Teal shows large cobalt-blue mark on shoulder when flying; drake Green-winged Teal shows red head prominently. One pair observed near mouth of Haultain River on the Churchill River, June 6. Few observed in marsh above Sandy Lake on the Churchill 
River, June 9. One pair observed below Du Brochet Lake, Cochrane River, July 31.

[Shoveller (Spatula clyplata)].-Pair observed Crooked River, May 15. Numerous Shagwenaw Lake, Churchill River, June 1, and Pelican Lake, June 3. Observed on Knee Lake, Churchill River, June 6.

[Pintail (Dafila acuta)].-Observed Big River, May 9; Beaver River, May 19. One pair observed Ile à la Crosse Lake, May 25. Numerous Pelican Lake, Churchill River, June 3. Observed adult with brood of young about eight days old on island above Kettle Falls, Churchill River, June 27. Caught two of the young. One adult and three full-grown young taken for food on $\mathrm{Du}$. Brochet Lake, August 6; eighteen in flock altogether.

[Scaup Duck (Marila marila)].-Observed Big River, May 9 ; Crooked Lake, May 12. Beaver River, May 19, 21. Three pair observed on inland lake on east shore at north end of Ile à la Crosse Lake, May 30.

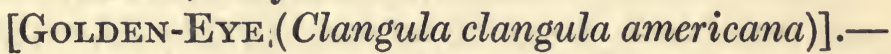
Observed Big River, May 9. Very numerous Crooked Lake, May 12, 13, and Beaver River, May 19. Numerous, in flocks, Shagwenaw Lake, Churchill River, June 1. Observed below Knee Lake, Churchill River, June 6. Observed number of duck on Cochrane River, August 13, which I think were this species in winter plumage; remarked that birds flocked and probably beginning to move slowly south in migration. One taken north of Fort Du Brochet, September 24. [White-winged Scoter (Oidemia deglandi)].- 
Observed Crooked Lake, May 13. Single bird observed on Black Bear Island Lake on the Churchill River, June 14. Three observed on Dead Lake, Churchill River, June 17. One pair observed with small flock of Surf Scoters on lake expansion on Reindeer River, June 30. Three observed Reindeer Lake, July 10.

Surf Scoten (Oidemia perspicillata).-Three specimens, one adult male taken on Ile à la Crosse Lake, May 31 ; two adult females taken on the Reindeer River, June 30. "Flock of about twelve Scoters together, all in pairs."

One specimen observed on inland lake on east shore at north end of Ile à la Crosse Lake, May 31. One pair observed in false bay above Sandfly Lake on the Churchill River, June 11. Those birds appear to prefer dead-water lakes (lakes without current). Four specimens observed on Black Bear Island Lake on the Churchill River, June 14. Six birds observed below Frog Portage on the Churchill River, June 2\%. Flock observed on inland lake north of Fort Du Brochet as late as September 30, passing in migration; they remained only one day on this lake, which was under constant observation at the time.

[SNow Goose (Chen hyperboreus hyperboreus)]. - Flock passed westward over Ladder Lake, Big River, May 9, in spring migration.

[CANADA Goose (Branta canadensis canadensis)]. - Observed one pair south end Ile à la Crosse Lake, May 24. One adult male taken on the Cochrane River, July 27. Stomach contained grasses and grit. Female with brood of young 
also seen in marsh at river-bend. Those were the only geese found in their breeding haunts.

[BITtern (Botaurus lentiginosus)]. - Observed at Polwarth, Sask., May 6 ; Beaver River, in marshy lower reaches, May 20. One observed below the mouth of Haultain River on the Churchill River on June 6. One observed at the mouth of Reindeer River, June 27. Two observed Reindeer River, June 29.

[Sandhill Crane? (Grus mificana)].-Flock observed settled on prairie grass, Craven, Sask., May 4, north-bound migration.

Nest containing two eggs found on inland lake on east shore at north end of Ile à la Crosse Lake, May 30. Only one pair breeding; locality completely isolated from mankind. On no other occasion were the breeding haunts of this species found. The eggs were medium sienna-buffish and had dark spots and splashes of darker colour. (See further description in Chapter III.)

Observed flock of this species passing south over mouth of Cochrane River, September 23. Birds giving voice to their unmistakable call as they planed overhead in easy view of my fieldglasses.

[Sora RaIl (Porzana carolina)].-Observed four in marsh off Beaver River, May 20. Observed on inland lake on east shore of Ile à la Crosse Lake, May 30. Nest with two eggs found in reeds in locality above noted, May 31.

[Coot (Fulica americana)].--Observed Beaver River, May 19. A number observed in marshes above Sandy Lake on Churchill River, June 8the first seen for some time. 
Red Phalarope (Phalaropus fulicarius).---A male taken on Sandfly Lake, Churchill River, June 11. On no other occasion was this species observed throughout the expedition.

Wilson's Phalarope (Steganopus tricolor).Two specimens : an adult female taken on Crooked Lake, May 13. "Bird alone, resting as if tired out, perhaps migrating." The other an adult male taken on the Beaver River, May 19. "Male and female together on floating weeds, on edge of small lake off Beaver River; birds in company with pair of Dowitchers, and a lesser Yellowleg."

Six pairs observed on inland lake on east shore, five miles from north end of Ile à la Crosse Lake; all birds breeding on south side of inland lake on limited area of swampy, mossy ground, but failed to find eggs, though birds flew and fluttered closely in great distress, May 30.

WILson's Snipe (Gallinago delicata). - Nest taken near Lake Ile à la Crosse, May 31. "Four eggs, slightly incubated, nest of damp grasses on ground among low snowberry bushes. Flushed bird off nest three or four times to-day and yesterday."

Three observed, May 30. Few observed over marsh drumming high in the air near mouth of Haultain River on the Churchill River, June 6 ; the first birds seen drumming. Two observed, flushed from marsh inland from $\mathrm{Du}$ Brochet Lake, August 9 ; noted that this species had not previously been seen for a long time.

Dowitcher (Macrorhamphus griseus griseus).Five specimens : a pair taken on Crooked Lake, 
May 13, have been compared with a series of this form and of $\boldsymbol{M}$. g. scolopaceus. Another pair taken on the Beaver River, May 19, and a male on Lake Ile à la Crosse, on May 23.

White-rumped Sandpiper (Pisobia fuscicollis). -A female taken on Sandy Lake, Churchill River, June 10, and a male taken on Sandfly Lake, Churchill River, June 11.

BaIrd's Sandpiper (Pisobia bairdi).-Four specimens : a female taken near Fort Du Brochet, Reindeer Lake, on July 17; and a male and two females taken on the Cochrane River, July 23.

Two observed below Du Brochet Lake, July 30.

Least Sandpiper (Pisobia minutilla).-Four specimens : a female, Reindeer Lake, July 13. "Bird alone breeding on island, apparently had nest." A female taken July 29, and a pair taken July 30 on the Cochrane River.

Two others observed on the Cochrane River, July 28.

Red-Backed Sandpiper (Pelidna alpina sakhalina).-A female, Churchill River, June 8, above Sandy Lake, "shot on small stony island, in company with seven semipalmated Sandpipers."

Semipalmated Sandpiper (Ereunetes pusillus). - Two pairs taken on the Churchill River below Pelican Rapids, June 2, from a flock.

Observed on Sandy Lake on the Churchill River, June 9, 10.

[Lesser Yellowlegs (Totanus flavipes)].-Few observed Crooked Lake, May 12. Observed Beaver River, May 9. Numerous on inland lake on east shore at north end of Ile à la Crosse Lake, May 30. Observed on lower reaches of the 
Cochrane River, July 18 : not seen for a long time. Bird calling, in alarm for nest or young, from the very top of a spruce tree, which seemed a ridiculous perch for a shore bird-yet it is one this species quite often chooses. Observed Cochrane River, July 20. One taken Cochrane River, July 26. Observed Cochrane River, July 28; Du Brochet Lake, August 2.

SANDERLING (Calidris leucophaea).-Three specimens taken from a flock of four, Cochrane River, July 21, "probably non-breeding birds."

SOLITARY SANDPIPER (Helodromus solitarius solitarius).- "A female with large egg in oviduct," Beaver River, May 18. Observed Cochrane River, July 20.

Spotted Sandpiper (Actitis macularia).-Two adults : a male, Crooked River, May 15, and a female, Lake Ile à la Crosse, May 23. Two sets of four eggs each, taken on Snake Lake and above Black Bear Island Lake, Churchill River, June 10,13 , also a downy young taken on the Cochrane River, July 29.

Observed Shagwenaw Lake, Churchill River, June 1; Sandy Lake on the Churchill River, June 9, 10 ; Sandfly Lake on the Churchill River, June 12. Trout Lake Churchill River, June 15. Have come to know this species as the most common shore bird in the territory. Saw one of this species being chased by a Red-tailed Hawk, Island Lake, Churchill River, June 26. Found nest with four eggs on island above Kettle Falls, Churchill River, June 27. Observed Reindeer River, June 29; south end Reindeer Lake, July 4. Noted on Reindeer Lake on July 9, 
and remark that very few seen at that date, though previously quite common. One observed Fort Du Brochet, July 17 ; nest containing four eggs found on dry, moss-covered hillside, near the foot of a pine tree. Observed Cochrane River, July 19, 26. Observed below Du Brochet Lake, Cochrane River, July 30.

American Golden Plover (Charadrius dominicus dominicus):- An adult female taken when in company with Kildeer Plover at the mouth of Mudjatick River on the Churchill River, June 2. "Eye, bill, and feet black."

Kildeer (Oxeyechus vociferus).-Seen in company with the Golden Plover, but no specimens taken. Observed at Polwarth, Sask., May 6 ; Big River, May 7, 9.

Semipalmated Plover(Agealitis semipalmata). - Four specimens : a male, Ile à la Crosse Lake, May 23; a pair Cochrane River, July 23; and a female taken 29 July, also on the Cochrane River.

Ruddy Turnstone (Arenaria interpres morinella).-Four specimens: a female found alone on Lake Ile à la Crosse, on May 22; a male also found alone on the same lake on the 23rd; and two females taken from large flock on June 9 on Sandy Lake on the Churchill River.

Observed on Sandfly Lake on the Churchill River, June 12.

Hudsonian Spruce Partridge (Canachites canadensis canadensis).-Eight specimens : six adults, and two downy young. A pair with nest and eggs taken at Lake Ile à la Crosse, May 25 ; male not preserved. "Eggs six in number, 
fresh; nest on ground close in at foot of alder bush; site dry open poplar knoll, surrounded by dense spruce and tamarack swamp; nest of dry leaves, same as carpet of surrounding ground, a few feathers lining nest." A male same locality, May 29. A female in moult, and a downy young, Reindeer Lake, July 10; the female has pin feathers on the sides of the head, and new tail feathers are appearing. A downy young, Cochrane River, July 20; was with other young and female parent when taken. A male taken, August 3; a female, August 4; and a male, August 7-all adults, Lake Du Brochet. The young could fly, though the first was only five inches in length.

Male observed below Frog Portage, Churchill River, July 27. Two shot north of Fort Du Brochet, October 9, and one on October 13, 16. Four shot near mouth of Cochrane River, October 19. One shot, October 30, in same locality. Note that there are a few north of Fort Du Brochet, November \%. One taken in same locality on December 10; this species evidently winter as far north as this point, but none seen any further north than latitude $58.5^{\circ}$. Two taken Fort Du Brochet, December 14. Flushed one at night on December 16 and noted bird had apparently no trouble to see in the dark.

[RufFed Grouse (Bonasa umbellus togata?)].Observed Crooked River, May 13; secured very reddish-brown female at head of Reindeer River, July 14. One taken north of Fort Du Brochet, October 1. This species appears rare in the Far North. 


\section{ANIMALS AND BIRDS COLLECTED}

Willow Ptarmigan (Lagopus lagopus lagopus). -One specimen, Fort Du Brochet, Reindeer Lake, November 4. "Same day first Barren-ground Caribou of the season were shot."

Natives at Fort Du Brochet say that this species arrives there about mid-October. "Diary of halfbreed, Philip Merasty, records : 'White Partridge seen at Fort on October 6, 1913, snow having fallen ere that date." Four specimens observed north of Fort Du Brochet, October 27; the first noted to arrive this winter. An Indian reported two seen on October 30 .

Note on November 7 that this species is now common north of Fort $\mathrm{Du}$ Brochet; birds rise with a startling flutter of wings out of the snow at the foot of the Scrub Pines. This species plentiful in neighbourhood of Thanout-Tua (Lake), Thlewiaza Or River, November 23 ; noted that those birds sometimes call exactly like Red Grouse when startled to flight.

There is a lake named "White Partridge Lake," or Kasba Lake, twenty miles south of the Barren Grounds, near neighbourhood where this species noted as plentiful.

Two observed north of Fort Du Brochet, December 12, and large pack seen on December 13. Observed December 15. On December 18, after searching three days without observing single bird of this species, I note : It is strange how those birds appear to come and go ; it may be because the food-supply of willow-shoots, and Labrador Tea-buds, on which they now feed, is so scant above the snow that they are soon picked bare, and then the birds move on to fresh feeding- 
ground. One taken on Reindeer Lake thirty miles south of Fort Du Brochet, December 30.

[Marsh Hawk (Circus hudsonicus)].-Observed Beaver River, May 20. First one seen since leaving the prairies. Apparently not numerous in this territory. One observed Sandfly Lake on the Churchill River, June 11. One observed Du Brochet Lake, Cochrane River, August 11; a female or young bird in brown plumage. This was the only specimen of this species seen to date in the Far North. Two young birds observed Cochrane River, on return journey, August 14.

Sharp-skinned HaWk (Accipiter velox).-An adult male, taken at Otter Lake, Churchill River, June 20.

American Goshawk (Astur atricapillus atricapillus).-A female, and set of three eggs, taken on Beaver River, May 16. Nest described in Chapter II.

[Western Red-taIled HaWK? (Butes borealis calurus)].-Observed single bird, Beaver River, May 16, 21; Black Bear Island Lake on the Churchill River, June 13. One observed chasing a Spotted Sandpiper, Island Lake, Churchill River, June 26.

Broad-wINGed Hawk (Butes platypterus).Three specimens: a melanotic male, Crooked River, May 14, is chocolate brown except for the tail-bars, which are normal; a male taken in same locality on May 15, and a female taken on Beaver River, May 16.

[Golden EAGLE? (Aquila chrysaëtos?)].-Observed two dark eagles (?), which appeared to be this species, over Black Bear Island Lake, 
Churchill River, June 13. One observed Trout Lake, Churchill River, June 16. One observed Island Lake, Churchill River, June 25. One also at mouth of Reindeer River, June 27, 28.

Northern Bald EAgle (Haliceetus leucocephalus alascanus).-An adult and three downy young taken: the first a male taken on the Churchill River, June 12; the downy young taken on Reindeer Lake, two on July 7 and one on July 10; these are marked: "Iris dark umber-brown; bill dark horn colour ; cere slightly more light brown; corner of mouth pale whitish yellow ; legs and feet pale whitish yellow." Nest of the first young was at the top of a spruce tree, which stood about twenty-five feet high in thick forest on an island of high, rocky elevation. The large nest was constructed with dead twigs of many sorts and sizes, and was lined with moss, grass, and feathers.

Nest found containing one young bird, six to ten days old. Shell of egg was white. Nest on top of dead spruce tree on a prominent point of land on shore, Knee Lake, Churchill River, June 5.

Three observed Black Bear Island Lake on the Churchill River, June 13. One observed lower reaches Cochrane River, July 18. One observed Fort Du Brochet, September 4.

Hawk ? Duck Hawk, or possibly [Gyrfalcon? (Falco rusticolus subsp.?)].-I'was greatly surprised in full winter to observe a fairly large Hawk (?) giving chase to Spruce Grouse near Fort Du Brochet, December 15. Again observed same species of Hawk (?) flying across a lake in same 
locality, December 24. On December 28, on Reindeer Lake, I noted: "Saw hawk again to-day and almost got within gunshot; believe it to be Gyrfalcon." On Cumberland Lake observed two winter-hawks : greyish white underparts, speckled probably lightly; clear black spot on ear coverts; upper parts dark; tail longish; bird large, would say about twenty inches, January 9, 1915. Possibly those latter were Goshawks?

Pigeon Hawk (Falco columbarius columbarius). -Seven specimens. An adult female (two other birds seen), Reindeer Lake, July 13. A female in company with four or five almost fully fledged young, three of which were taken, Lake $\mathrm{Du}$ Brochet, August 3 ; the young have the wings and tail not fully grown, and traces of down on the head; the old bird is in very worn plumage with one fresh blue tail feather, but showing no other sign of the blue plumage. Two fully fledged young birds (two others seen), Lake Du Brochet, August 7.

Observed on Lake Du Brochet on August 8, 11.

[SPARRow HawK (Falco sparverius sparverius)].-Female observed Big River, May 10.

American Osprey (Pandion halliaëtus carolinensis).-Three specimens. A female, Crooked Lake, May 13. A male taken at nest, Lake Ile à la Crosse, May 25 ; " nest containing single egg on very top of broken-off dead Jack Pine, nest mainly built of dry twigs, inside thickly lined with damp mud, grass, and moss; fish scales on edge of nest ; the male bird was bringing both talons full of damp moss to nest when 
shot." A female taken with nest and two eggs, Knee Lake, Churchill River, June 6.

Found nest of this species on Sandy Lake, on the Churchill River, June 10. Female on nest, but did not disturb her.

One observed at narrows entering into Key Lake, Churchill River, June 24. Observed south end, Reindeer Lake, July 4. Single bird observed Cochrane River, July 20, 21. One observed carrying a fish lengthwise, parallel to the body and head facing onwards, Du Brochet Lake, Cochrane River, August 11. One observed near Fort Du Brochet, September 2.

[GReat Horned OWL (Bubo virginianus subsp.?)].-Nest found on Crooked River, May 15, containing two downy half-grown young; one a beautiful buff-cream colour, the other more grey. Adult female on nest when found. Nest not large in comparison with size of bird, and situated in strong fork of Black Poplar tree; tree not yet in leaf. Nest composed of dead poplar and lichen-grown spruce twigs, and lined with rabbits' hair. Noted on Ile à la Crosse Lake on May 25, that have not heard any Great Horned Owls calling at night in this locality. Previously had heard them every night. On reaching north end of this lake this species was again heard on May 29.

AMERICAN HAwK OwL (Surnia ulula caparoch).-A male taken on Lake Du Brochet, August 1.

[Belted Kingfisher (Ceryle alcyon)].-First pair observed on Beaver River, May 16; few pair Beaver River, May 19. Observed Churchill River, June 1, in neighbourhood of Shagwenaw Lake. 
One observed Pelican Lake, Churchill River, June 3. Few observed below Knee Lake on the Churchill River, June 6; also above Sandy Lake on the Churchill River, June 8.

Nest found in hole at the top of a rocky bank of about twelve feet elevation. Nest situated about ten feet above shore. Straight tunnel in, then the nest in a slight hollow $2 \mathrm{ft}$. 6 in. from the entrance; nest unlined, except with a few small fish-bones, and contained six young about eight days old. Foot of Grand Rapids, Churchill River, June 25. Note on Cochrane River on July 23 that none of this species now seen. Single specimen observed near Fort Du Brochet on September 22.

[Northern Hairy Woodpecker (Dryvbates villosus subsp.?)].-Found nest containing three young almost fully fledged on green poplar tree on island above last rapid, above Black Bear Island Lake on the Churchill River, June 12.

Arctic Three-toed Woodpecker (Picoides arcticus).-An adult male taken on the Cochrane River, July 31 ; yellow crest much worn, exposing the white bases of the feathers.

Alaskan Three-toed Woodpecker (Picoides americanus fasciatus).-An adult female, Fort Du Brochet, October 22.

Yellow-Bellied SAPsucker (Sphyrapicus varius varius). - Two males taken at Big River on May $7,11$.

Nest found containing young in hole in green poplar tree. Hole about eight feet up, and facing south-east. Did not disturb nest; below Key Falls, Churchill River, June 25. Believe 
one specimen seen Cochrane River, July 23; but identity not absolutely certain.

Boreal Flicker (Colaptes auratus borealis).One female Cochrane River, July 31, the male seen. There is another adult female in the W.S. National Museum, taken at Lake Du Brochet, September 26, 1890. This form is included in the range of luteus in the A. O. W. Check List.

[Flicker. Golden-Winged Woodpecker ( $\mathrm{C} O$ laptes auratus subsp.?)].-Observed at Big River, May 7. Pair mating, Big River, May 9. Manner of courtship : they sit side by side on tree-trunk and at intervals gesticulate with their heads, thrusting them up and down, and softly emitting "Thuca, Thuca, Thuca," Then they pause for an interval and are motionless except that their eyes roll rapidly and show white by the glint of the overhead sun. The male Flicker shows more golden yellow under the wings when in flight.

Species numerous, Beaver River, May 19.

Observed Pelican Lake, Churchill River, June 4. Numerous ,Sandy Lake neighbourhood, Churchill River, June 10.

Found nest containing ten eggs in green poplar tree, nest about ten feet up tree-trunk, Churchill River, June 11.

Nest found on top of dead birch-stump, at elevation of about fifteen feet, on Trout Lake, Churchill River, June 17; nest not disturbed. Observed below Frog Portage on the Churchill River, June 27; Reindeer River, June 29; south end Reindeer Lake, July 4.

Found nest containing well-fledged young on shore of Reindeer Lake, July 10. Did not dis- 
turb nest. Not many Flickers observed in this neighbourhood.

Observed Fort Du Brochet, July 17 ; Cochrane River, July 18, 25 ; Du Brochet Lake, August 2.

Possibly some of the birds observed north of the Churchill River were the Boreal Flicker (Colaptes auratus borealis), but this I could not decide merely by observation.

[NIghtнawк (Chordeiles virginianus subsp.?)].Observed at Stanley Mission, Junc 23, where I noted that they had been commonly seen along the entire route to that point on the Churchill. Observed mouth of Reindeer River, June 27, 28. Single bird observed Reindeer Lake, July 9previously a most common bird. Observed Fort $\mathrm{Du}$ Brochet, July 16. About a dozen seen, Cochrane River, July 18. Observed Cochrane River, July 24, 25, 26, 28 ; Du Brochet Lake, August 6, 8. Note that this species feed through the day after a bad storm, probably through said storm hindering them from feeding properly at evening and morning as usual; also they feed in the daytime when the atmosphere is very close and still before rain. Observed Cochrane River, on return journey, August 13, 15.

[KInGBIRD.(Tyrannus tyrannus)].-Observed above Island Lake on the Churchill River, June 25.

Phobe (Sayornis phobe).-A male taken on Reindeer River, June 30.

Nest containing five eggs well incubated found in false bay above Sandfly Lake on the Churchill River, June 11. One observed Reindeer River, June 27.

Olive-sided Flycatcher (Nuttallornis bore- 
alis).- Two males taken on Lake Ile à la Crosse, May 27, 28.

Observed on Sandy Lake on the Churchill River, June 9.

Alder Flycatcher (Empidonax trailli alnorum).-Three specimens: a male, Churchill River, June 6 ; two from the Cochrane River, July 27, 28, the latter a female; all taken in willows at edge of marsh.

Observed below Du Brochet Lake, Cochrane River, July 29.

Least Flycatcher (Empidonax minimus).A female taken on Lake Ile à la Crosse, May 29, and a male, Reindeer River, June 28.

Identified certainly on Reindeer River, June 29, but have heard those birds singing in the forests for the past month, and now know to whom the sweet, clear song belongs.

[HoRNed LARK (Otoeoris alpestris subsp.?)].Observed Big River, May 10 ; south end Ile à la Crosse Lake, May 23. Noted at Fort Du Brochet on September 18 that numbers have passed south during the stormy broken weather of the last three days. Flocks observed, restlessly cheeping and flighting close to the ground, near Fort Du Brochet, September 22. Observed north of Fort Du Brochet, September 25.

Canada JAY (Perisoreus canadensis canadensis). - One immature bird, taken in Reindeer Lake, July 11, is somewhat difficult to place. It compares well with one of about the same age from forty miles south-west of Calgary, Alberta, August 4, 1895 ; and is not so dark above as a younger bird from near Latchford, Ontario, 
June 10, 1906. Preble refers to a breeding bird from Pelican Narrows, Churchill River, in the W.S. National Museum, ${ }^{1}$ and in fact Reindeer Lake is well within the known range of canadensis.

Observed south end Reindeer Lake, July 4; Sucker Bay, Reindeer Lake, July 6 ; Fort Du Brochet, July 17; lower reaches of the Cochrane River, July 20, 21, 23, 24. Observed Cochrane River, July 27, 29, 30, 31. There is an inland lake, some twenty to twenty-five miles long, west of Cochrane River, named by the Indians Wiskajon ${ }^{2}$ Lake. This neighbourhood appears to be their regular habitat. Observed Du Brochet Lake, August 6, 8; north end Du Brochet Lake, August 11; north of Fort Du Brochet, September 26 and November 5.

The Northern Shrike is called by the Indians the "White Wiskajon," and certainly its light flight among thickets resembles that of the true Wiskajon.

Northern Raven (Corvus corax principalis).Five specimens: three from Churchill River, a young bird taken when just fledged and flown from the nest above Pelican Rapids, June 2; an adult female below Great Devil Rapids, June 18; and a young bird fledged and in company with parent and two other young, Otter Lake, June 20; two adult males taken December 15, one on Lake Du Brochet, the other on Reindeer Lake.

Found nest in cleft of low rock cliffs on shore of

1 North American Fauna, No. 27, 1908, p. 402.

- Canada Jay. 
Pelican Lake. Six partly fledged young perched on ledge adjoining; a nest found two days ago was in fairly high poplar tree, Churchill River, June 4. One observed below Knee Lake on the Churchill River, June 6. One pair observed Black Bear Island Lake on the Churchill River, June 13. One observed Island Lake, Churchill River, June 26. Observed south end Reindeer Lake, July 4. Four observed Reindeer Lake, July 8. Two observed lower reaches Cochrane River, July 18. One observed Cochrane River, July 21, 23 ; observed July 24. Few observed below Du Brochet Lake, Cochrane River, July 30, 31. Observed Du Brochet Lake, August 2, 5; Cochrane River, below Du Brochet Lake, August 14. Two observed Fort $\mathrm{Du}$ Brochet, September 4. Number of Ravens observed following the southward migration of Caribou north of Fort Du Brochet, November 5, 8, after the manner of Vultures. They sometimes voice brief musical calls from the depth of their throat: p-r-r-o-o uttered singly, and repeated at longish intervals; and crr.... crr.

One observed Theitaga Lake near latitude $60^{\circ}$ on November 28, probably following Caribou. One taken near Fort Du Brochet, December 14. Those birds appear to remain in vicinity of the Caribou herds all though winter.

Crow (Corvus brachyrhynchos subsp.?).-An immature female taken on the Reindeer River, June 29 ; this bird compares well with a breeding female from Craven, Saskatchewan, much better than it does with Ontario birds, and may better be placed with the Western Crow (C. b. hesperis), 
but owing to lack of material of comparable age I hesitate to do so.

Observed Big River, Sask., May 7, 9. Large number nesting in wood at back of Ile à la Crosse Post, May 22. Noted June 2 that I see crows every day : at that date entering Churchill River from Ile à la Crosse Lake. Numerous in neighbourhood of mouth of Haultain River on the Churchill River, June 6.

Observed above Sandy Lake on the Churchill River, June 8. Numerous Sandy Lake on the Churchill River, June 10. Observed Sandfly Lake, Churchill River, June 12. Few observed Otter Lake, Churchill River, June 20. Crows at Stanley Mission, June 23. Observed neighbourhood Island Lake on the Churchill River, June 25; Reindeer River, June 29, 30, but not so commonly seen during the last two days. Observed Reindeer Lake, July 11 . Observed in neighbourhood of deserted teepees on the Cochrane River, July 27: this species not seen for some time. Observed Du Brochet Lake, August 8.

Yellow-HEAdEd BlackBIRD (Xanthocephalus xanthocephalus).--Specimen taken at mouth of Mudjatick River, Churchill River, June 2. First of this species seen this year.

Breeding haunts encountered in marsh at entrance to Pelican Lake, Churchill River, June 3.

[RED-WINGed BlackBIRd (Agelaius phoniceus subsp.?)].-Observed Big River, May 9; Beaver River, May 21; inland lake on east shore at north end of Ile à la Crosse Lake, May 30 ; Pelican Lake, Churchill River, June 2. Nest with three 
eggs found on Churchill River, below mouth of Haultain River, June 6. Observed in marsh above Sandy Lake on the Churchill River, June 8. Number observed neighbourhood Island Lake, Churchill River, June 25.

Rusty BlackBird (Euphagus carolinus).Three specimens from Lake Du Brochet, August 7 : an adult male, "iris clear yellowish white"; an immature (female?), "iris medium clear umberbrown"; and an immature male, "iris pale sage-green."

Observed Cochrane River, July 21; Du Brochet Lake, August 6.' Observed during first two weeks in September at Fort Du Brochet, feeding apparently chiefly on ground cranberries and bilberries.

[BREWER's BLACKBIRD (Euphagus cyanocephalus)].-Numerous atBigRiver, May 7. Two pair observed Cochrane River, July 19, 20. Observed Cochrane River, July 26. Observed a bird with food in bill for young, July 27. Observed July 28, 29, 30, below Du Brochet Lake.

[BRONZED GRACKLE (Quiscalus guiscula ceneus)]. - Numerous at Big River, May 7. Observed Beaver River, May 21. One pair observed on inland lake east shore Ile à la Crosse Lake, May 30 ; Pelican Lake, Churchill River, June 3. Observed on Sandy Lake on the Churchill River, June 9, 10; Sandfly Lake, Churchill River, June 12. Number observed neighbourhood Island Lake, Churchill River, June 25, 26.

[Pine Grosbeak ? (Pinicola enucleator subsp.?)]. -Observed bird which I thought was this species on the Cochrane River, July 25. 
PURPLE Finch (Carpodacus purpureus purpureus).-Two adult males taken on Big River, May 9 ; a female seen with them.

(Observed some wild flocks of finches flying over the forest which I think were this species, Cochrane River, July 21. There is just a possibility of confusing them with Grosbeaks or Crossbills, so this note is given with reservation).

REDPOLL (Acanthis linaria linaria).-Three specimens :I an adult male with rosy breast, Cochrane River, July 21, "bird in company with one young, bill dark brownish," two males, an adult and young, Lake Du Brochet, August 10, "bill flat, black" in the young.

Observed Cochrane River, July 23, 24, 28, 29, 30, below Du Brochet Lake. Great many observed in flocks feeding on birch catkins, Cochrane River, below Du Brochet Lake, August 13, 14. Observed north of Fort Du Brochet, October 25, those birds feed on small shoots of the tamarack tree (American larch) in late Fall, though at earlier date birch catkins appear to be their general and favourite food. This species still commonly seen, and heard giving voice to their small companionable twitter, north of Fort $\mathrm{Du}$ Brochet, November \%. Observed TheitagaTua (Lake) near latitude $60^{\circ}$, November 25 . No specimens secured, as shot-gun behind at Du Brochet.

Snow Bunting (Plectrophinax nivalis nivalis).One specimen Reindeer Lake, October 23. "Large flocks of these birds for the past fortnight."

Single bird-the first appearance of their migration into the south-observed Fort Du 
Brochet, September 2. Plentiful north of Fort $\mathrm{Du}$ Brochet on October 18, 19; birds migrating.

Very large flocks about on October 23 : recorded still plentiful October 26; noted October 29. Three observed south of Cumberland Lake, January 11, and noted that those the first observed since leaving the Far North.

[LAPLAND LONGSPUR (Calcarius lapponicus lapponicus)].-Observed single specimen south end Ile à la Crosse Lake, May 22. Large numbers of Longspurs passing in migration; Lapland, only species certainly identified, Fort Du Brochet, September 18.

[Chestnut-Collared Longspur (Calcarius ornatus)].-Observed Crooked Lake, May 12.

Savannah Sparrow (Passerculus sandwichensis subsp.).-Three specimens : one from Lake Ile à la Crosse, May 27; an adult male from Fort Du Brochet, July 17 ; and a juvenile female, Cochrane River, July 28. These are very dark birds, much more so than alaudinus should be, and very different from the light race that breeds in Southern Saskatchewan, which is no doubt nevadensis.

Observed east shore Ile à la Crosse Lake, May 30. Observed at Stanley Mission on the Churchill River, June 23. One taken from talons of Pigeon Hawk on Du Brochet Lake, August 7. Observed during autumn migration at Fort Du Brochet, September 18.

Leconte's SParrow (Passerherbulus lecontei). -Two specimens : one of a pair, Churchill River, June 2 ; a male, Haultain River, June 6 ; " birds breeding here."

Harris's Sparrow (Zonotrichia querula).- 
Seven specimens. An adult female and a juvenile male, Cochrane River, July 26 ; an adult male, Cochrane River, July 30. "Male and female with fledged young," a female, and young bird, Cochrane River, July 31 ; a female, Cochrane River, August 3, "bird in company with others, probably her fully fledged young"; an adult female, Lake Du Brochet, August 6-adult's " bill dull sienna-brown," juveniles" "bill blackish brown, yellow along edges of mandibles and at corners of mouth." So little is known of the early plumage of this sparrow that a description of the young of July 31 may not be out of place: "Length 3.75 in.; pileum with feathers brownish black, indistinctly edged with greyish buff, producing a dark crown with a few greyish-buff spots; throat and chin greyish buff, throat with a few blackish-brown spots; chest brownish buff streaked with brownish black; flanks buff with brown streaks ; rest of under parts buffy white. Above brown streaked with black, upper tail coverts brownish buff, tail darker than in adult; wing coverts tipped with buff.

Three observed south end Ile à la Crosse Lake, May 24. Their first encountered breeding haunts were found on the Cochrane River about latitude $58^{\circ}$. Country fairly mountainous, and the hillside, which the birds frequented, was bare of tall growth, and bouldered and thickly strewn with dead timber-for at some past date the countryside had been swept by forest-fire. Small spruce and scrub pine, of a height of two feet to six feet, grew here and there, while willows, tamarack, and small spruce grew somewhat more densely 18 
along the margin of the river; thus appeared the breeding haunt of the Harris's Sparrow, Cochrane River, July 26. Observed Du Brochet Lake, August 2: note that I have not heard this species sing : they have a loud, sharp alarm chirp when disturbed near young. Adult and fledged young observed $\mathrm{Du}$ Brochet Lake, August 9. Observed north end Du Brochet Lake, August 10. Gambel's SPARRow (Zonotrichia leucophrys Gambelii).-Three specimens : an adult male and a juvenile male, Reindeer Lake, July 16 ; and a young male, Cochrane River, July 26.

Observed Ile à la Crosse Lake, May 24. Observed Fort Du Brochet, July 14; and noted that birds appear to be nesting there. On July 17 noted that this species plentiful in neighbourhood of Fort $\mathrm{Du}$ Brochet, but that they had been nowhere seen in their breeding haunts until this post was reached. Observed Cochrane River, July 21, 28. Observed below Du Brochet Lake, July 31.

[White-Throated Sparrow (Zonotrichia albicollis)].-Observed Big River, May 10; Crooked Lake, May 13 ; inland, on east shore, at north end of Ile à la Crosse Lake, May 30. Noted on June 2 that this species are encountered every day, at that date had entered the Churchill River. Observed below Dead Lake, Churchill River, June 18, and noted that this species had not been seen for some days. Number singing at daybreak at Stanley Mission, June 24. Observed south end Reindeer Lake, July 4; and on Reindeer Lake, July 7.

Tree Sparrow (Spizella monticola monticola). 
-A male taken on Reindeer Lake, July 11 ; "two pairs breeding on an island, first of this species seen on this expedition." A female, Fort Du Brochet, July 17; " bird had young almost fully fledged."

Observed Cochrane River, July 20, 21, 23 ; and again on July 26. Noted that this species appears to breed numerously below Du Brochet Lake, Cochrane River, July 29, 31. Du Brochet Lake, August 1, 2, 6, 9. Observed as late as September 26 north of Fort Du Brochet.

Chipping Sparrow (Spizella passerina passerina).-A male taken on Lake Ile à la Crosse, May 27.

Observed on inland lake on east shore Ile à la Crosse Lake, May 30. Nest with four eggs found on shore of inland lake, May 31; bird secured. Observed Pelican Lake, Churchill River, June 4. Nest containing one egg found on island on Sandy Lake on the Churchill River, June 11. Single specimen observed above Trout Lake on the Churchill River, June 15, also on Dead Lake Churchill River, June 13. Those birds always seen in neighbourhood of, or on, spruce trees.

Few observed on Rapid River Lake on the Churchill River, June 24. Observed below Frog Portage, Churchill River, June 27. Very plentiful, Reindeer River, June 30, and at south end of Reindeer Lake, July 3. Observed Sucker Bay, Reindeer Lake, July 6 ; Reindeer Lake, July 7. Observed Du Brochet Lake, August 3 ; previously this species not seen for some time.

[Slate Coloured Junco (Junco hyemalis hyemalis)].-Observed at Canford, Sask., May 6. Nu- 
merous at Big River, May 7. Observed one pair Otter Lake, Churchill River, June 20. Observed Reindeer Lake, June 29, and at south end of Reindeer Lake, July 3. Observed Reindeer Lake, July 6, 7, 9. Common on Reindeer Lake, July 10. Observed Cochrane River, July 19, 21, 24, 28 ; $\mathrm{Du}$ Brochet Lake, August 3, 6, 8. Number observed, as if beginning migration south, at Fort Du Brochet, September 2. Few still near the Fort on September 18, 22. Observed as late as September 30 north of Fort Du Brochet.

Song Sparrow (Melospiza melodia melodia).A pair taken on Reindeer River, June 28.

Observed Big River, May 10. Fairly plentiful on lower reaches Beaver River, May 21. Singing at midnight north-east shore Ile à la Crosse Lake. Noted June 2, when entering Churchill River, that this species seen every day. Nest containing five eggs found in tall dry hay-grass where willows grew at wide intervals. Nest lined with very fine grasses, Churchill River below mouth of Mudjatick River, June 2. Observed Pelican Lake, Churchill River, June 4. Nest containing six eggs found on shore of Sandfly Lake on the Churchill River, June 12. Nest containing three eggs and two newly hatched young found on ground among grass near trees on wooded island above Trout Lake, Churchill River, June 15. Nest containing six eggs found in grass among dead tree-stumps in country burnt by forest fire, Trout Lake, Churchill River, June 17. A number observed at Stanley Mission, June 23. Song Sparrows often heard singing on small almost bare islands, and they are the only 
small birds that appear to inhabit such a place, Churchill River, June 25. Observed below Frog Portage, Churchill River, June 27; south end of Reindeer Lake, July 3, 4; Reindeer Lake, July 7, 11. Note that no Song Sparrows Cochrane River, July 23.

Lincoln's SPARRow (Melospiza lincolni lincolni).-A male taken on Reindeer River, June 29.

Swamp Sparrow (Melospiza georgiana).-A male taken below mouth of Haultain River, Churchill River, June 6. "Small colony of these birds breeding in this place."

Observed at Big River, May 7.

Fox Sparrow (Passerella iliaca iliaca).-Four specimens; all males : one Reindeer Lake, July 11; three Cochrane River, July 18, 24 and August 3 ; the first bird seen was carrying food to its fledged young. Fledged young taken, but specimen too much damaged to make a skin of.

Observed Reindeer Lake, July 13; Fort Du Brochet, July 17; Cochrane River, July 19, 20, 21, 28 ; Du Brochet Lake, August 1 ; north end Du Brochet Lake, August 10.

[House Sparrow (Passer domesticus)].-Those were at Big River Town-site, and even as far afield as Ile à la Crosse Post. To an extraordinary extent those birds have spread since first imported to America.

CuIfF Swallow (Petrochelidon lunifrons lunifrons).- Two females taken on Sandy Lake, Churchill River, June 9 ; a pair, Cochrane River, August 6 ; fully fledged young in company with these last. Those latter were the first of this species to be observed since leaving Sandy Lake. 
Tree Swallow (Iridoprocne bicolor).-Two specimens : a female, Crooked River, May 15; a young male, Du Brochet Lake, August 6. Two sets of eggs taken on Sandy Lake on the Churchill River, June 11, nests in old woodpeckerholes in dead poplars.

Observed Crooked Lake, May 12 ; Pelican Lake, Churchill River, June 4. Numerous in Knee Lake neighbourhood on the Churchill River, June 6. Observed on Sandy Lake on the Churchill River, June 9, 10, 11. Numerous at Stanley Mission on the Churchill River, June 23. Observed one near south end of Reindeer Lake, July 7; the first of this species encountered for some time. One pair observed Fort Du Brochet, July 17.

Bank Swallow (Riparia riparia).-A male taken on Sandy Lake, Churchill River, June 9.

Colony of this species nesting on sand-bank at the river-edge. Many young flown from nests, and in the air with their parents. The nestingholes were at both high and low elevation in a steep sloping bank of some twenty feet. Opened one cavity, from which a swallow flew out, and found the nest at the end of a $2 \mathrm{ft} .6 \mathrm{in}$. tunnel, containing three eggs-all of which were addled. Birds flew out of many holes, and therein were probably nests of young or a second complement of eggs.

Bohemian Waxwing (Bombycilla garrula).Two specimens from Cochrane River : a juvenile male taken July 28, "iris dark-not reddish brown like adult"; an adult female, July 30.

Observed Cochrane River, July 18, 19, and 
noted that they appear to be breeding here. Numbers observed Cochrane River below Du Brochet Lake, July 29.

Cedar "Waxwing (Bombycilla cedrorum).-A male taken on Key Lake, Churchill River, June 25. Female taken also, and dissection proved it to be in breeding condition.

Adult bird was taken from stomach of a pike weighing $3 \frac{1}{2} \mathrm{lbs}$., caught on Island Lake, Churchill River, June 25.

Northern Shrike (Lanius borealis).-A male taken on the Cochrane River, October 19.

A young bird observed below Du Brochet Lake, Cochrane River, July 31. This species is called the "White Wiskajon" by the Indians, and in light flight through thickets the bird certainly closely resembles the Canada Jay at times.

Red-eyed Vireo (Vireosylva olivacea).-A male taken at Dead Lake, Churchill River, June 17.

Secured one specimen above Sandy Lake on the Churchill River, June 8. Observed above Island Lake on the Churchill River, June 25, 26. Observed below Frog Portage on the Churchill River, June 27, and at south end of Reindeer Lake, July 3.

Blue-headed VIREo (Lanivireo solitarius solitarius).-A male taken at Lake Ile à la Crosse, May 28.

Black ANd 'White Warbler (Mniotilta varia). -A male taken on Beaver River, May 17.

Tennessee Warbler (Vermivora peregrina).Three males taken: two from Lake Ile à la Crosse, May 27 and June 2; one from Dead Lake, Churchill River, June 17. 
Observed on Rapid River Lake, Churchill River, June 24. Note that at this point bird-life is disappointingly scarce. Observed below Frog Portage on the Churchill River, June 27, and on Reindeer River, June 28, 29. Noted as being very plentiful, Reindeer River, June $\mathbf{3 0 .}$

Yellow Warbler (Dendroica astiva astiva). -Two males taken: one Lake Ile à la Crosse, May 27; the other Reindeer Lake, July 4; this latter is only a little more worn than the May bird.

Observed Sandfly Lake on the Churchill River, June 11. One specimen observed above Trout Lake on the Churchill River, June 15; also on Dead Lake, Churchill River, June 17. Few observed Island Lake, Churchill River, June 25, 26. Observed Churchill River, June 27; Reindeer River, June 28 ; south end of Reindeer Lake, July 3 ; Reindeer Lake, July 11 ; Fort Du Brochet, July 17; Cochrane River, July 28; Du Brochet Lake, August 1; when noted that this species is very scarce now. Observed north end Du Brochet Lake, August 10.

Myrtle WARBLer (Dendroica coronata).Three specimens: two adult males from Big River, May 7, 8; a juvenile, Cochrane River, July 2\%. Hoover's Warbler (D. C. hooveri), has recently been revived by Dr. Oberholster, and the range of this western race of the Myrtle Warbler is given as reaching east to Central Mackenzie, but the adult taken May 8, which I have been able to compare with series of both the supposed races, is nearer to coronata.

Observed female in neighbourhood of her nest, but prolonged search failed to find its hiding- 
place in the spruce trees, Churchill River, June 27. Nest found in spruce tree situated against main trunk about 12 feet above the ground and contained five young about two weeks old, Reindeer River, June 29. Observed commonly south end Reindeer Lake, July 3, 4. Observed Sucker Bay, Reindeer Lake, July 6. Reindeer Lake, July 7. Commonly seen on Reindeer Lake, July 10. Observed July 11, 13. Observed Cochrane River, July 19, 21, 28; Du Brochet Lake, August 1, 3; north end Du Brochet Lake, August 12.

Black-Poll 'WARbler (Dendroica striata).A male taken on Beaver River, May 18.

One observed south end Reindeer Lake, July 4, and on Cochrane River, July 26. One observed $\mathrm{Du}$ Brochet Lake, August 3, carrying insects in bill for young. Observed inland from Du Brochet Lake, August 5.

Palm Warbler (Dendroica palmarum palmarum).--A male taken on Beaver River, May 18.

'WATER-Thrush (Seiurus noveboracensis noveboracensis).- Three specimens : a female, Beaver River, May 20; a male, Knee Lake, Churchill River, June 6 ; and a female, Reindeer River, June 28 ; these are close to Grinnell's WaterThrush (S. n. notabilis), in colour.

Observed Reindeer River, June 29. One taken Reindeer Lake, July 10. Observed Cochrane River, July 23, 24, 26, 27, and on July 29, 31, below Du Brochet Lake; observed Du Brochet Lake, August 1, 6, 8. Note that this species is common on Cochrane River, and that they feed along the water's edge like a Pipit or Wagtail 
-sometimes they make short rising flights, of some 10 to 15 feet, into the air in pursuit of insects. Observed north end Du Brochet Lake, August 11. Wilson's 'WARBLer (Wilsonia pusilla pusilla). -A male taken at Lake Ile à la Crosse, May 26.

[REDStarT (Setophaga ruticilla)].-- One observed Beaver River, May 19.

[Tree Creeper (Certhia, familiaris americana)]. -Observed Big River, May 10.

Red-breasted Nuthatch (Sitta canadensis). $\rightarrow$ A male taken at Lake Ile à la Crosse, May 25.

One observed in winter south of Cumberland Lake on January 11.

[Chickadee (Penthestes atricapillus subsp.?)].Observed below Dead Lake, Churchill River, June 18. Observed a pair with a family of fully fledged young on Rapid River Lake, Churchill River, June 24. Observed south end of Reindeer Lake, July 3.

Hudsonian Chickadee (Penthestes hudsonicus hudsonicus).-Three specimens : a pair taken at Big River, May 8 ; and a young bird, Cochrane River, July 24. This last is interesting, though full grown (length 5 inches) the pileum instead of being soft greyish brown, is blackish brown, forming a distinct cap, while the hind neck and back are brownish grey.

Observed south end of Reindeer Lake, July 3 ; few observed, Du Brochet Lake, August 3.

Ruby-CROWNED KInglet (Regulus calendula calendula).-Three specimens : a male, Lake Ile à la Crosse, May 28; a female taken with nest containing young, Churchill River, July 3 ; and a male taken Reindeer Lake, July 9. The 
nest taken July 3 is described as follows : " nest in young spruce tree about ten feet high, nest against limb and about eight feet up. Nest contained seven young about fourteen days old."

One singing in spruce tree on island in Trout Lake, Churchill River, June 16. Observed Sucker Bay, Reindeer Lake, July 6 ; Reindeer Lake, July 7. Commonly seen, Reindeer Lake, July 10, 11. Observed Fort Du Brochet, July 17 ; Cochrane River, July 9, 24, 26 ; Du Brochet Lake, I August 2, 3; Cochrane River, on return journey, August 15; Fort $\mathrm{Du}$ Brochet, September 18.

GREY-CHEEKED ThRUSH (Hylocichla aliciae alicice).-Two males taken: Big River, May 11 ; Churchill River, June 18-this latter is in very worn plumage, "bird in company with mate."

OLIVE-BACKed Thrush (Hylocichla ustulata swainsoni).- Two males taken Ile à la Crosse, May 25; and Black Bear Island Lake, Churchill River, June 14.

One observed near mouth of Reindeer River, June 23. One taken on Cochrane River, July 26.

Hermit Thrush (Hylocichla guttata pallasi). -A male taken on Beaver River, May 18.

[AMERICAN Robin (Planesticus migratorius migratorius)].-Numerous Big River, May \%. Observed above Sandy Lake on the Churchill River, June 8, singing sweetly near camp. Observed Sandy Lake, Churchill River, June 10; not numerous. One or two on Black Bear Island Lake, Churchill River, June 15. Single bird observed Otter Lake, Churchill River, June 20. 
Three or four pairs observed nesting in grove of poplars, Churchill River, above Island Lake, June 25. Observed one pair, Reindeer Lake, July 10 ; none previously seen for some days. Observed Fort Du Brochet, July 16; Cochrane River, July 18; Cochrane River, July 21. This species is by no means numerous in the Far North in this territory. Observed on Cochrane River, July 26. Observed a number of Robins below Du Brochet Lake on the Cochrane River, July 28.

Numbers appearing about Fort Du Brochet, September 2, the commencement of migrations south. At same locality, on September 18, I state: Many robins passed about two weeks ago ; a few seen here still.

Observed near Fort Du Brochet, September $22,26,30$. 

THIS BOOK IS DUE ON THE LAST DATE STAMPED BELOW

AN INITIAL FINE OF 25 CENTS WILL BE ASSESSED FOR FAILURE TO RETURN THIS BOOK ON THE DATE DUE. THE PENALTY WILL INCREASE TO 50 CENTS ON THE FOURTH DAY AND TO \$1.00 ON THE SEVENTH DAY OVERDUE.

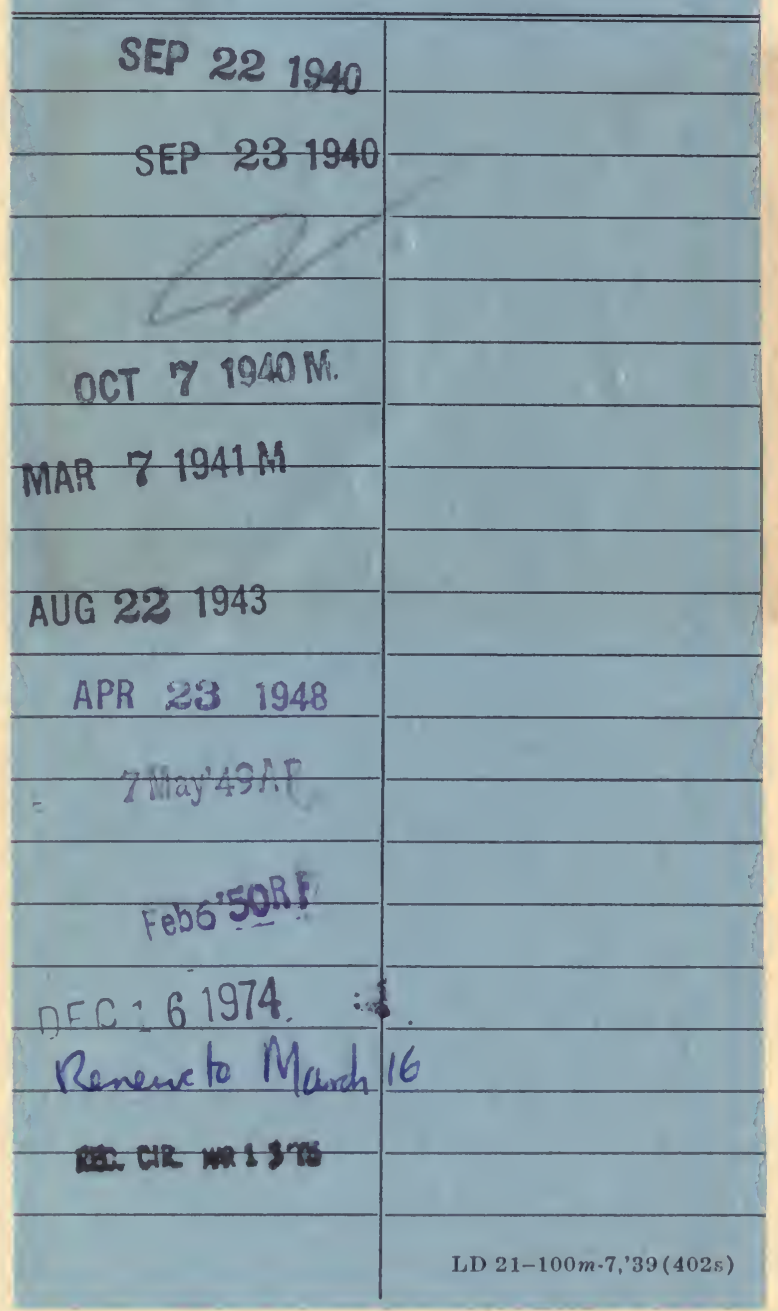




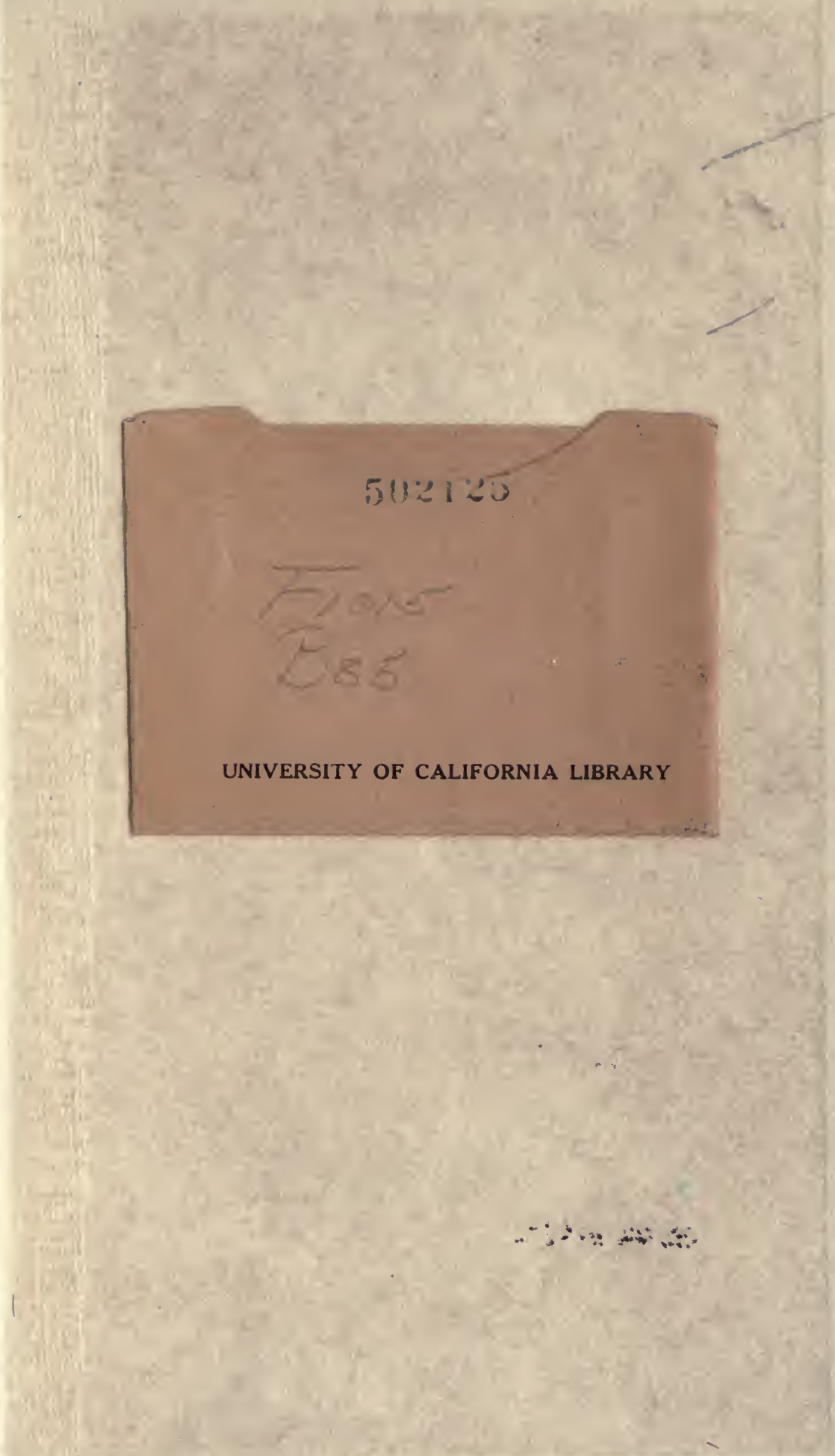




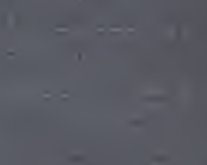

$x=$ 